دراسات في آثار الوطن العربي ؛

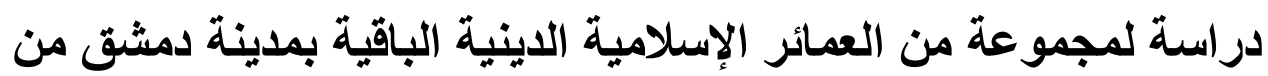

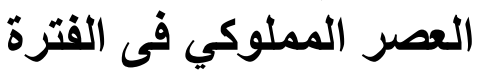

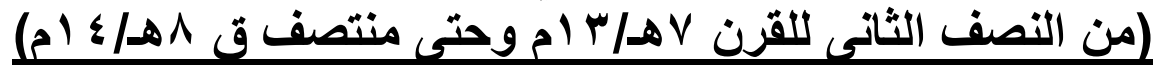

لد. محمود مرسيى مرسئ

تمتعت مدينة دمشق بأهية كبيرة عبر الحقب التاريخية المتعاقبة ويعد العصر

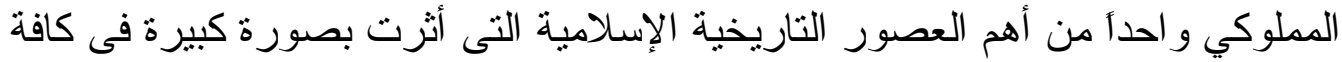

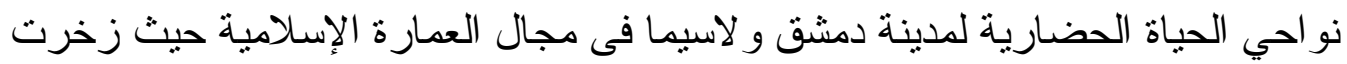

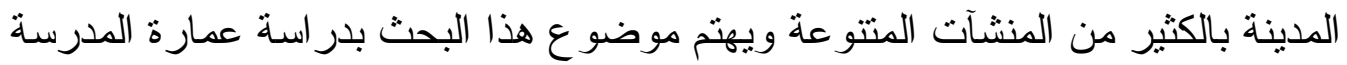

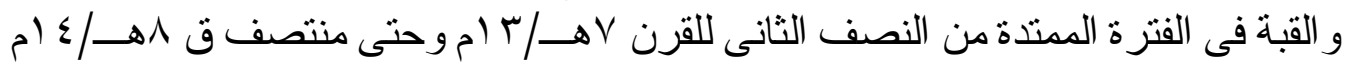

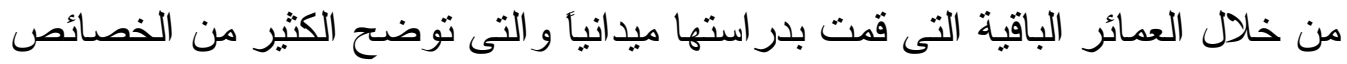

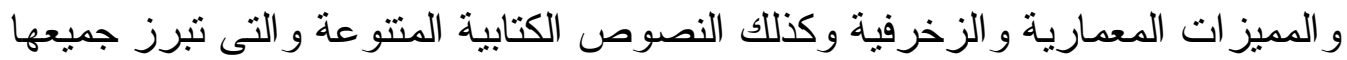

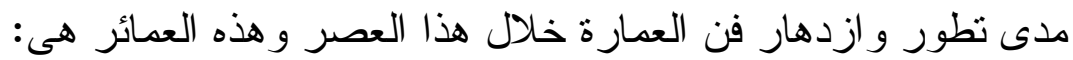

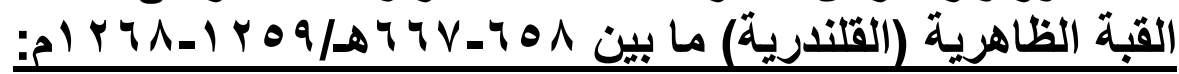

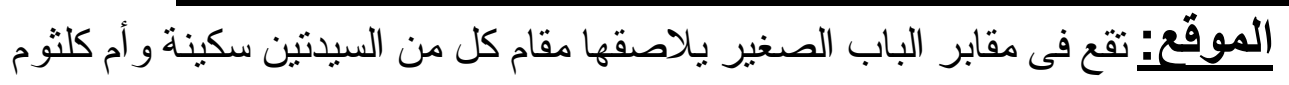

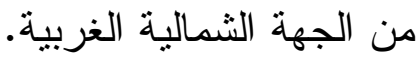

\section{المنشئ: التهن:}

أنشأها السلطان الظاهر بييرس البندقدارى حيث سُجل أسمه على الساكف (العتب)

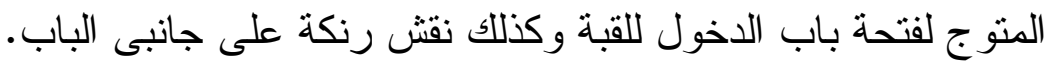

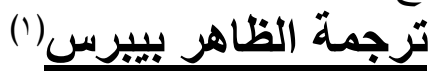

"د. (الد محود مرسى مرسى - كلية الآثار - قسم الآثار الإسلامية - جامعة القاهرة.

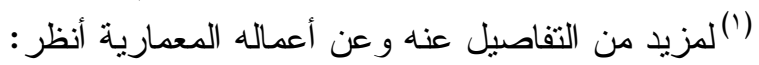

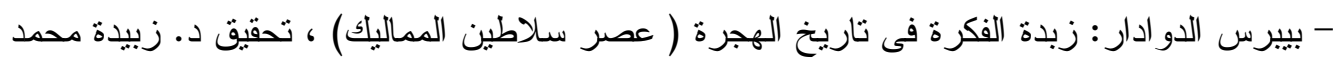

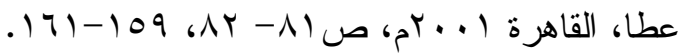

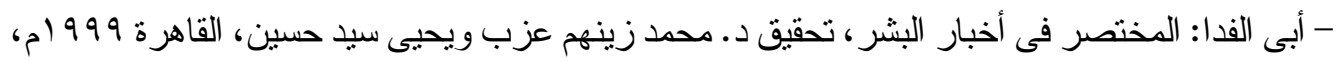
جr - اليونينى : ذيل مر آة الزمان، مطبعة مجلس دائرة المعارف العثمانية بحيدر آباد الدكن، لهند ـ 97 ام مج

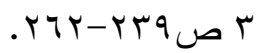

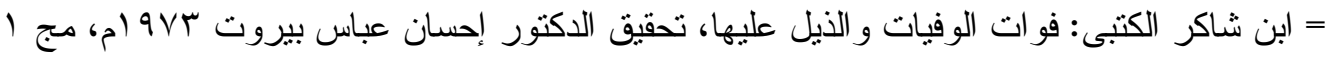
1... 


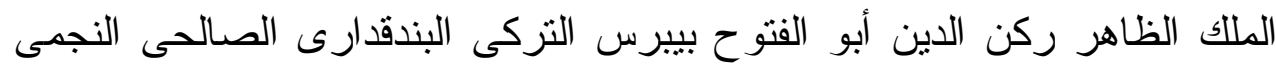

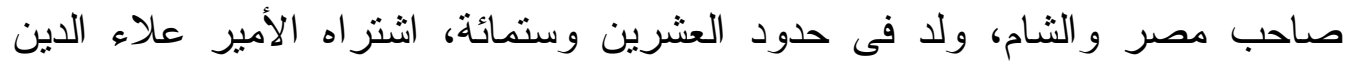

\section{ص}

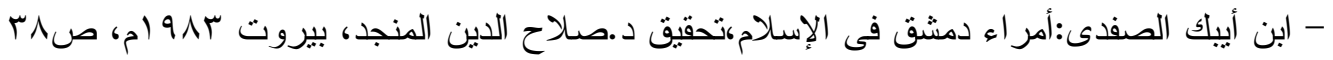

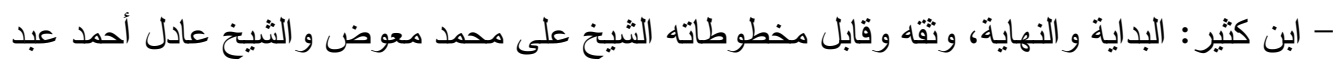

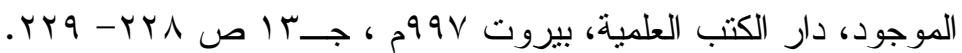

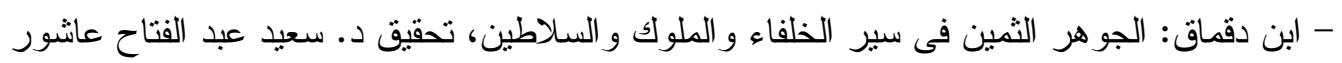

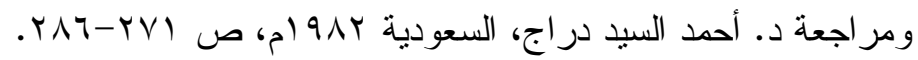

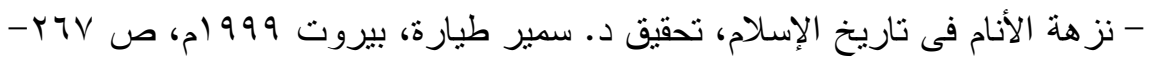

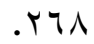

- المقريزى: السلوك لمعرفة دول الملوك، صححه ووضع حواثيه محمد مصطفى زيادة، القاهرة ا $190 \mathrm{~V}$

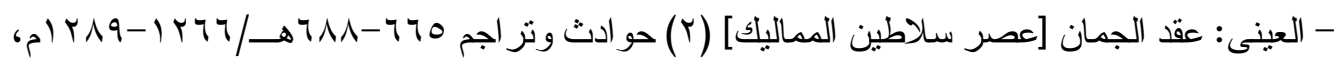

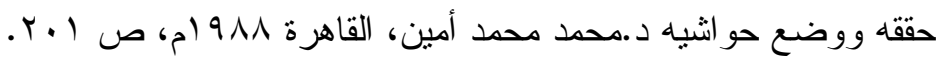

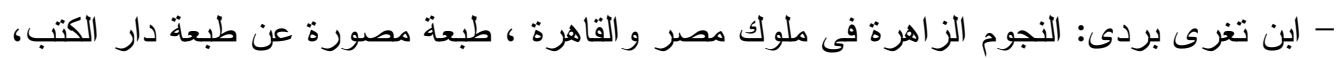

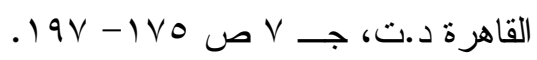

- المنهل الصافى و المستوفى بعد الو افى، حققه ووضع حو اثنيه د. نبيل محمد

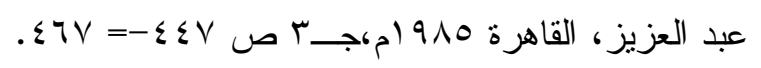

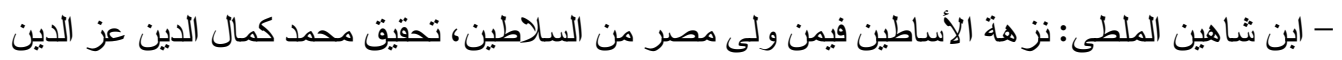

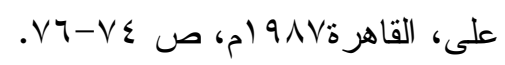

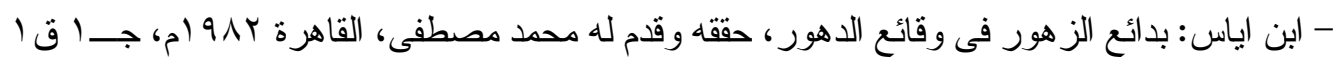

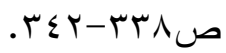

- ابن طولون: إعلام الورى بمن ولى من الأتر الك بدمشق الثشام الكبرى، تحقيق محمد أحمد دهمان، دمشق

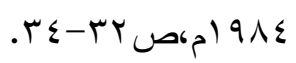

- ابن العماد: شذر ات الذهب فى أخبار من ذهب، تحقيق محمود أرناؤوط وعبد القادر أرناؤوط، بيروت

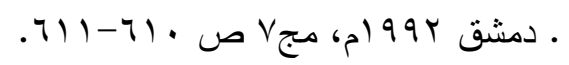

- سوسن سليمان يحيى: ألقاب السلطان بييرس على هولى الآثار نصوصها ودلالاتها، بحث فى مجلة كلية

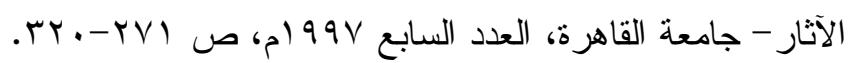

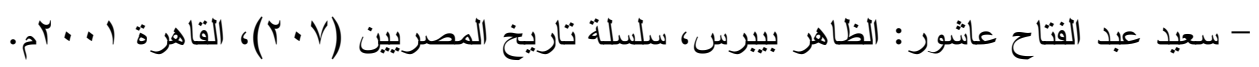
1... 
البندقارى، فقبض الملك الصالح نجم الدين أيوب على البندقدارى و أخذ ركن الدين المذكور

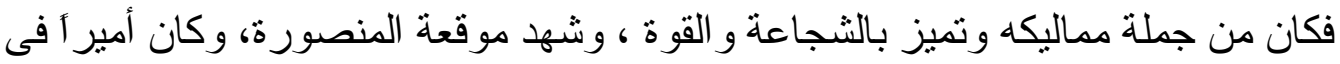

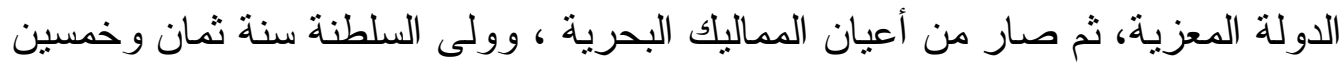

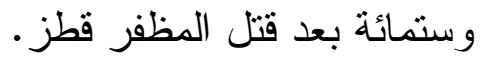

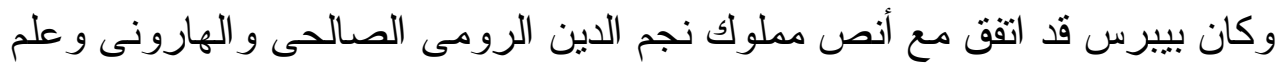

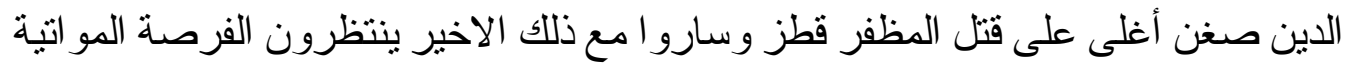

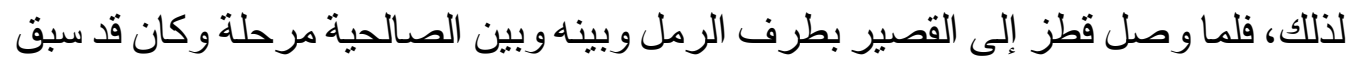

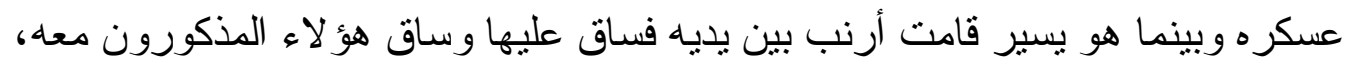

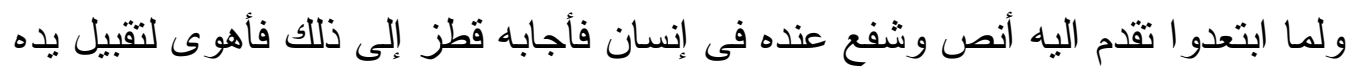

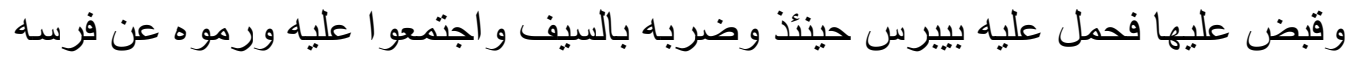

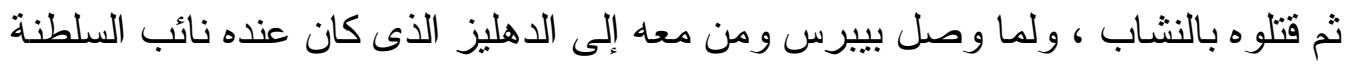

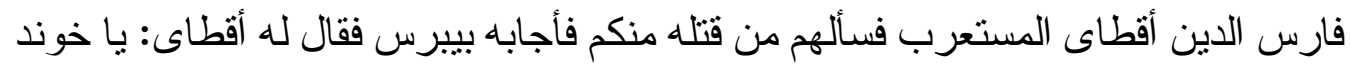

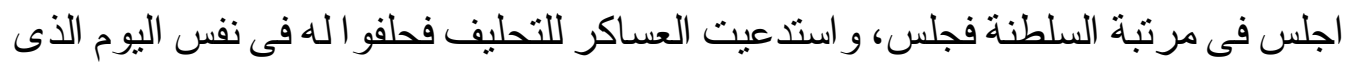
فئل فيه قطز .

و استقر بييرس فى السلطنة وتلقب بالملك القاهر ، ثم غير بعد ذلك لقبه ليصبر الملك الظاهر

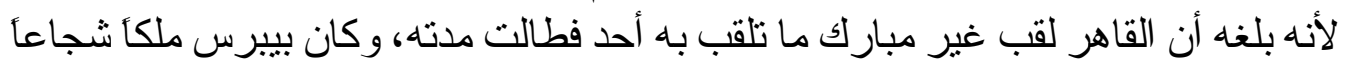

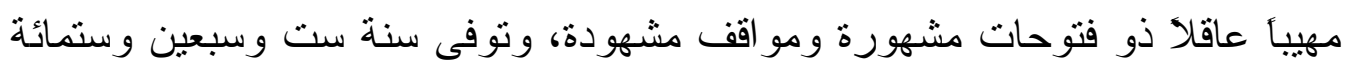

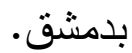

قيل فى سبب موته أن القمر إنكسف كسوفأ كليا وشاع بين الناس أن ذلك بسبب أنه

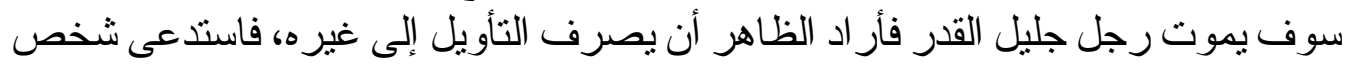

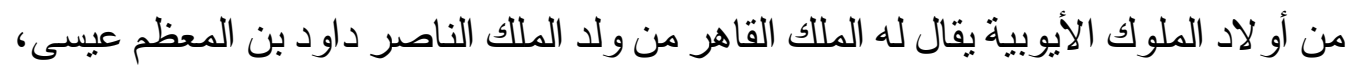

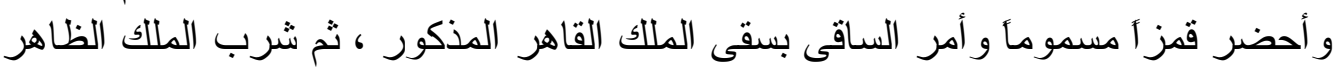
ناسيأ من نفس الكأس على اثر شرب الملاك القاهر فمات القاهر عقب ذللك و أما الملك الظاهر

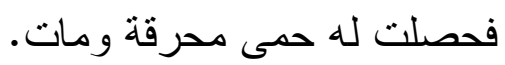
وكتم الأمير بدر الدين بيليك الخزندار نائبه موته عن العسكر وأظهر أنه مستمر الأبهر

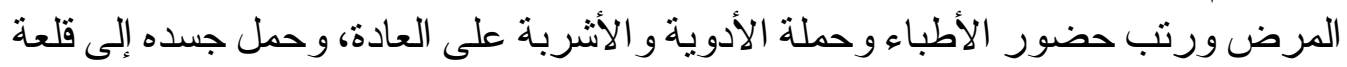

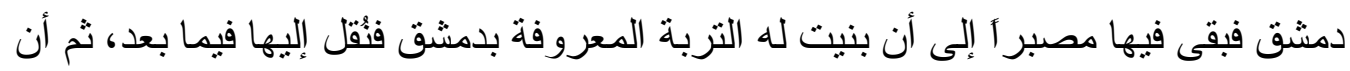

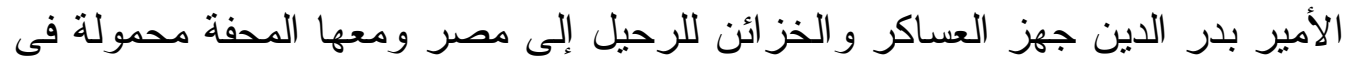
الموكب محترمة كأن السلطان فيها مريض إلى أن وصل الكل إلى قلى العة الجبل بالقاهرة 
المحروسة فأنشاع الخبر وتولى بعده ابنه الملك السعيد ناصر الدين بركة خان.

\section{تناول المؤرخين والباحثين لها:}

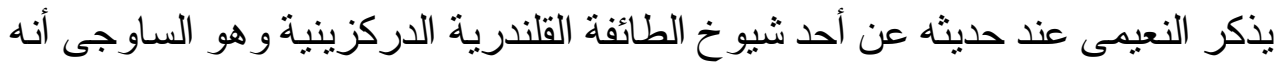

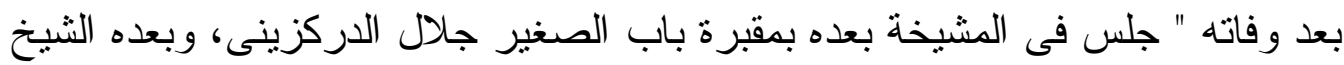

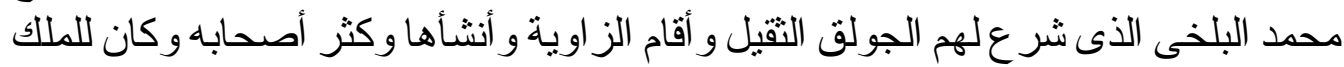

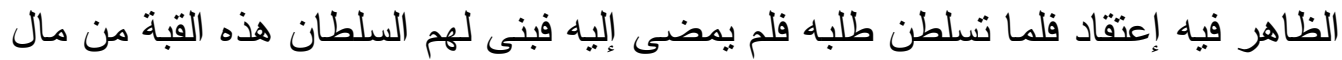

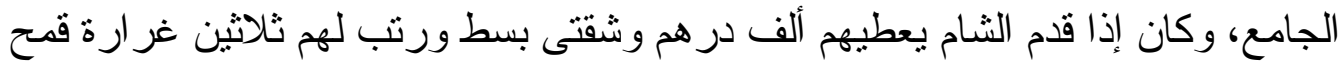

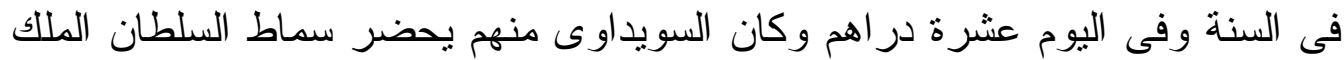

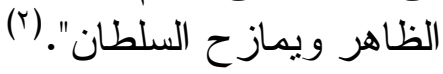

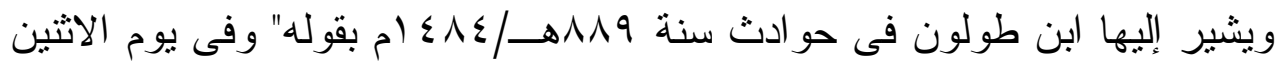

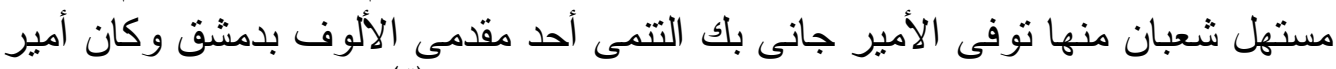

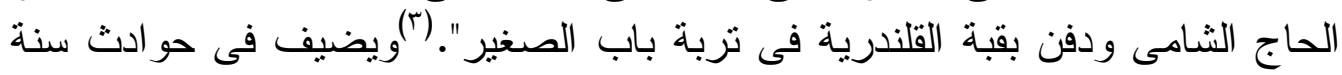

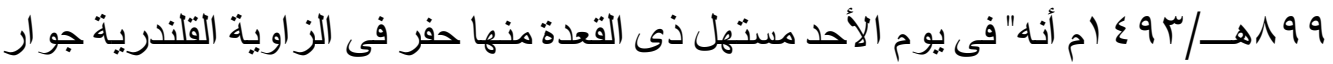

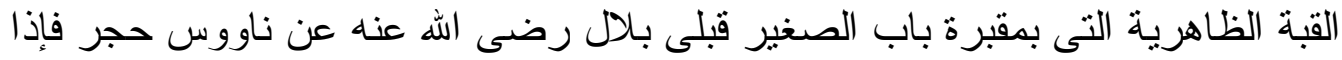

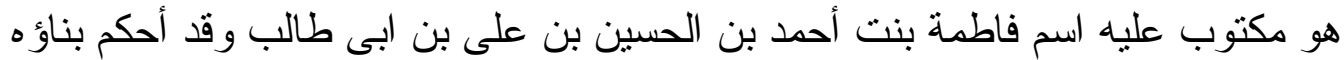
عليها وبجو ارها نصيبة عليها مكتوب إنه قبر الحافظ ثقة الدين أبى القاسم على بن العن عساكر

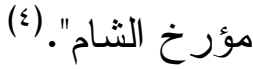
ويتضح من هذه النصوص التاريخية أن القبة التى بناها الظاهر بيبرس لطائفة القلندرية

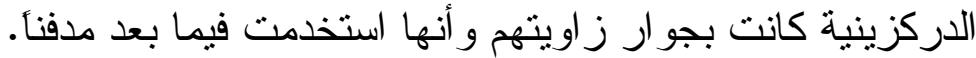

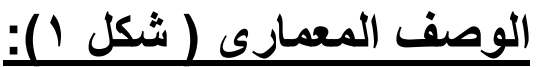

(r) النعيمى: الدارس فى تاريخ الدارس، أعد فهارسه إيراهيم شمس الدين ، بيروت •99 (م،جـr

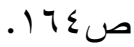

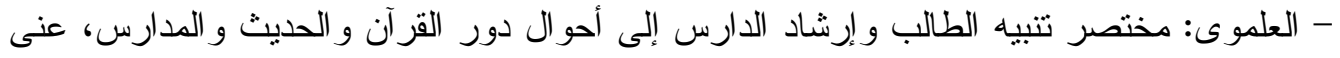

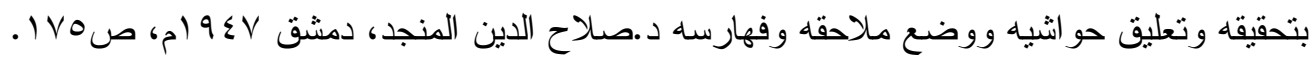

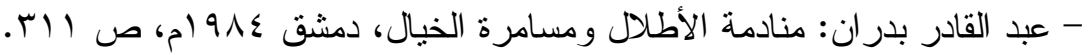

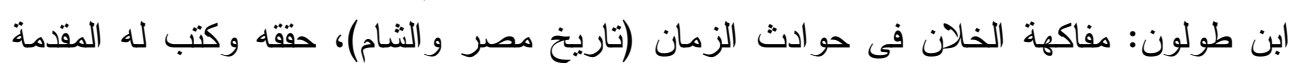

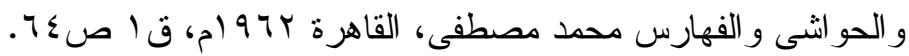

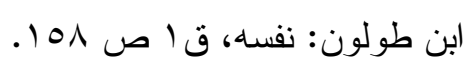


تتألف هذه القبة من مكعب سفلى يتوسط جداره الجنوبى محر اب قصير من الحجر الحبر

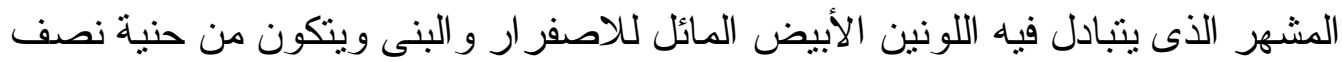

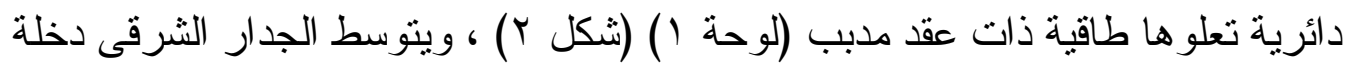

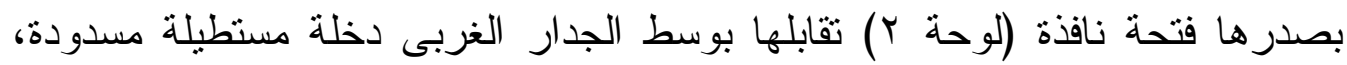

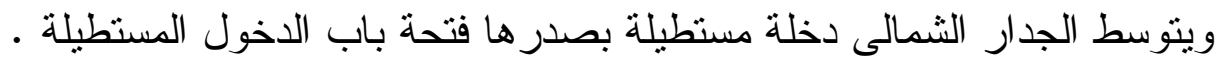

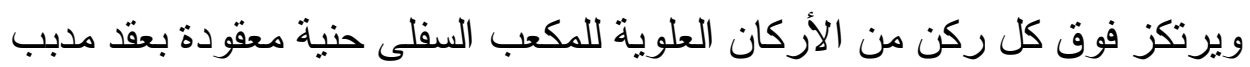

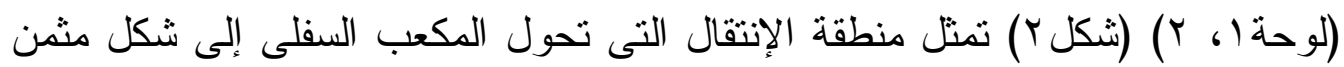

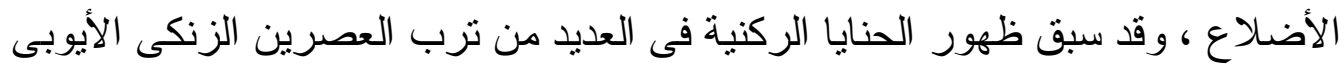

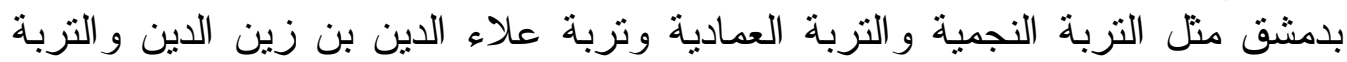

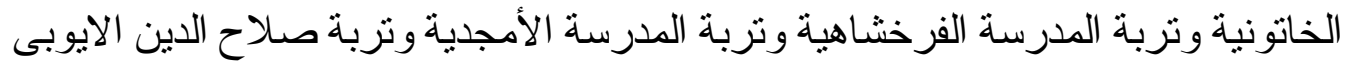

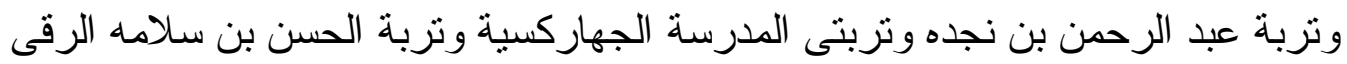

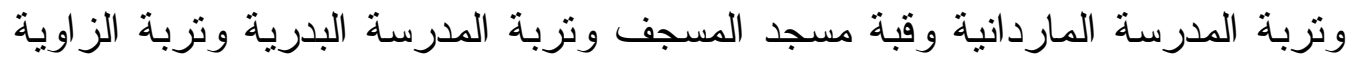

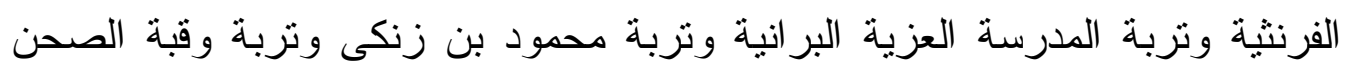

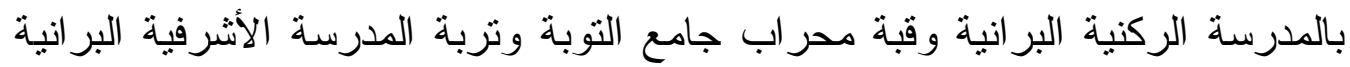

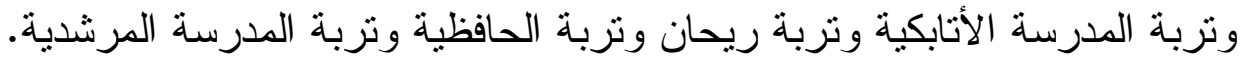

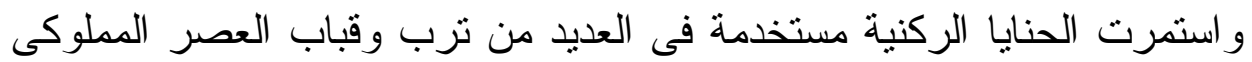
بدمثق ومن نماذجها الباقية تربة مدرسة الظاهرية الجية الجو انية وقبتى التربة العنابة العادلية البر انية

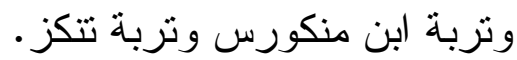

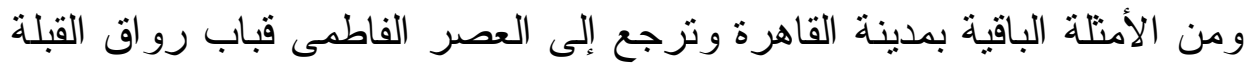

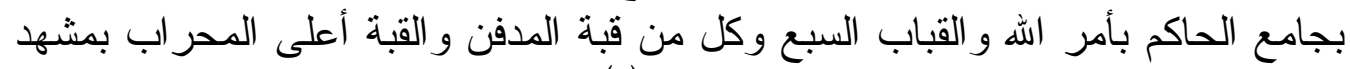

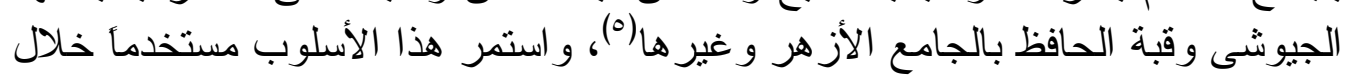

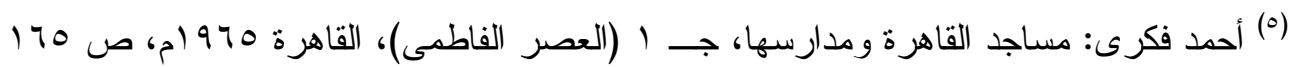

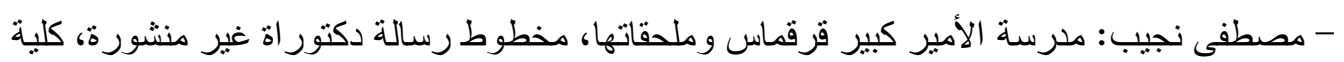

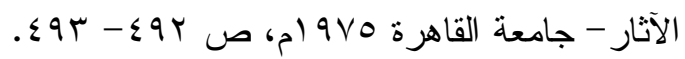

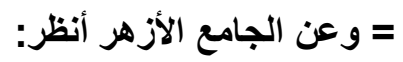

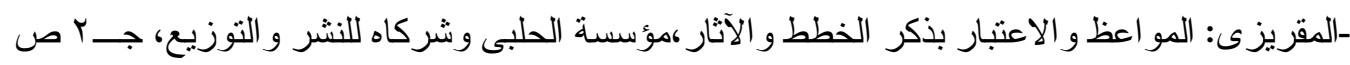
$. r V V-r V T$

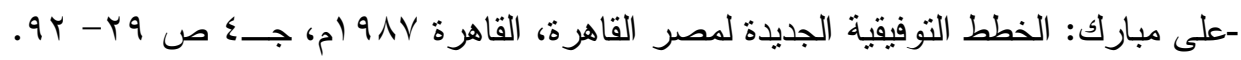

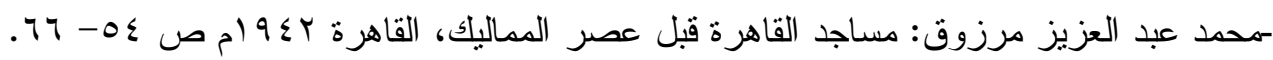




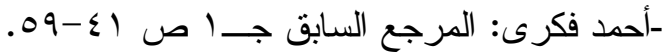

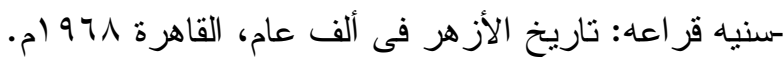

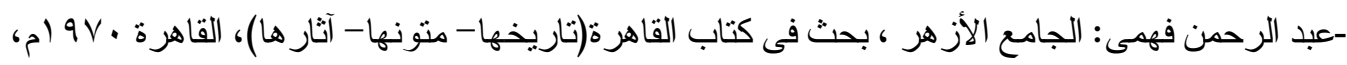
ص ص

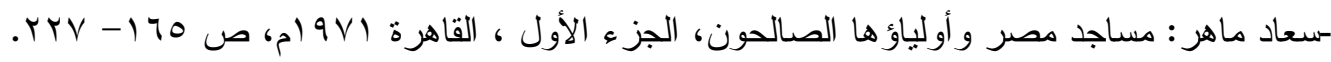

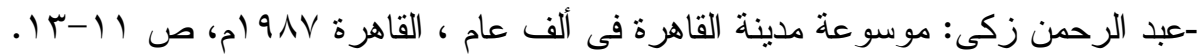

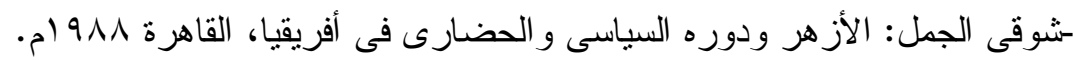

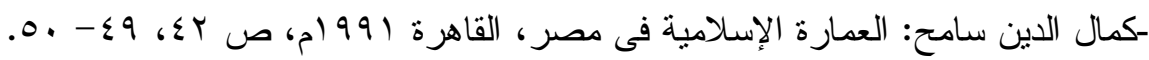

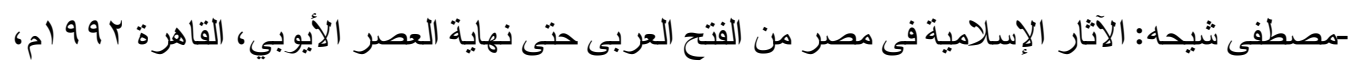
ص $117-1.10$ -آمال العمرى وعلى الطايش : العمارة فى مصر الإسلامية ( العصرين الفاطمى والأيوبي )، القاهرة . VE-TV ص ص 997 -عبد القادر الريحاوى: قمم عالمية فى تراث الحضارة العربية الإسلامية المعمارى و الفنى، دمشق . -أحمد عبد الرازق: العمارة الإسلامية فى العصرين العباسى والفاطمى، القاهرة r ... rم، ص $.179-1 \leq 7$

وعن جامع الحاكم بأمر الله أنظر:

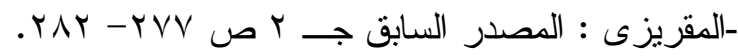

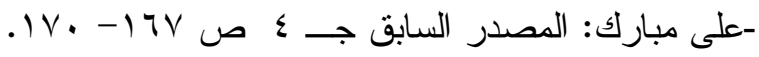

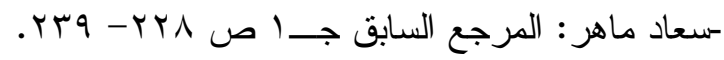
-عبد الرحمن زكى: المرجع السابق ص r ب . r.

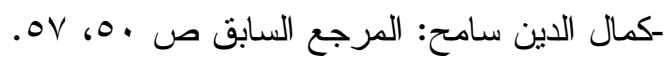

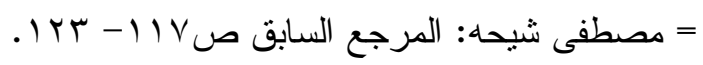

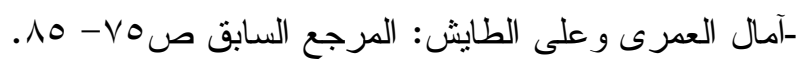

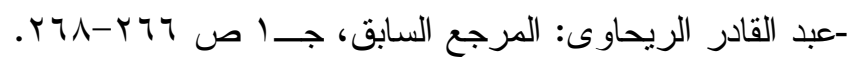

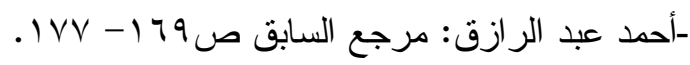
وعن مشهد الجيوشى أنظر:

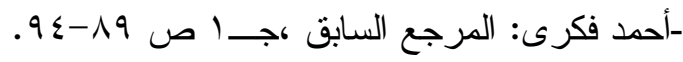

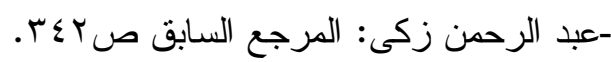


العصر المملوكى ومن نماذجه قبة محر اب مسجد آق سنقر وقبة مدفن كجك الملحقة بنفس

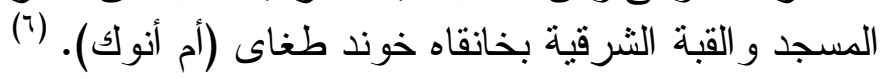

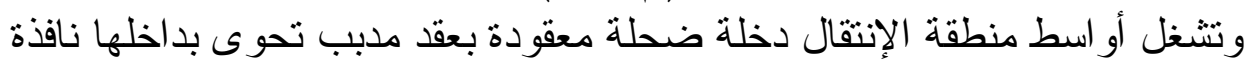

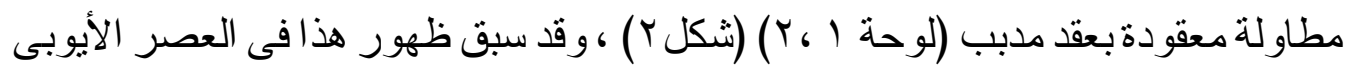

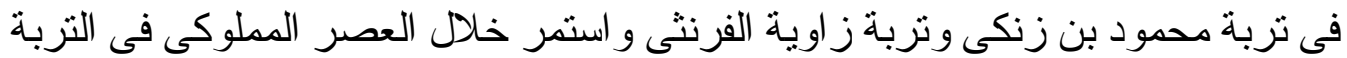
الكجكرية. ونزتكز فوق منطقة الانتقال وأو اسطها القبة (لوحةب) الملساء المزينة بزخارف

كمال الدين سامح: المرجع السابق ص

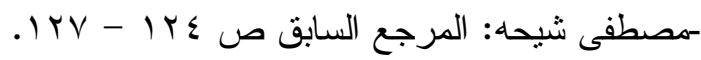

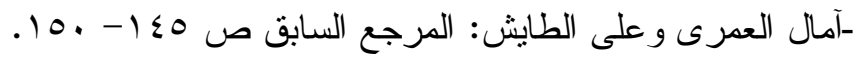

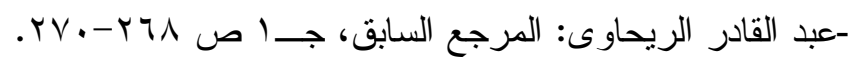

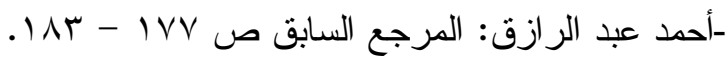

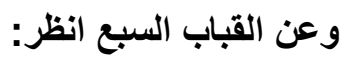

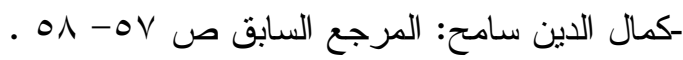

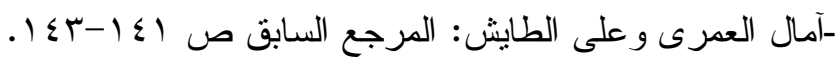

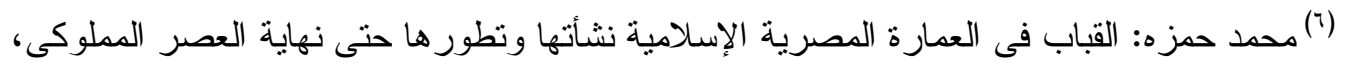

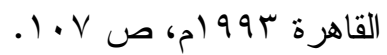
وعن مسجد اق سنقر أنظر:

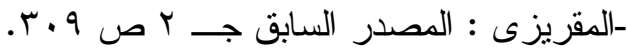

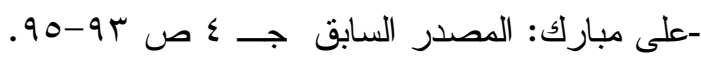

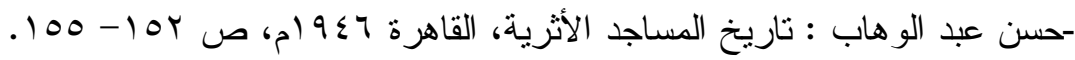

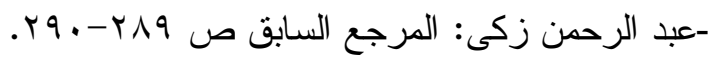
وعن خانقاه خوند طغاى (أم أنوك) أنظر:

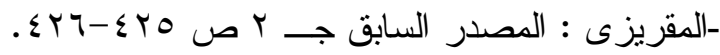

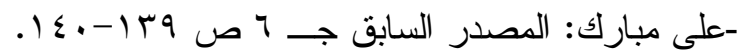

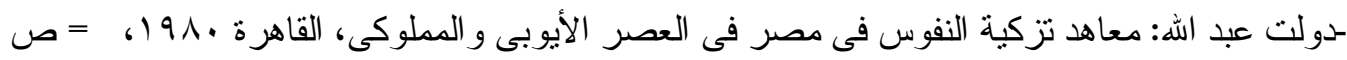
r

-عاصم رزق: خانقاو ات الصوفية فى مصر فى العصرين الأيوبي و المملوكى، القاهرة \99 إم، جـا

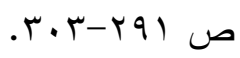


حديثة نباتية و هندسية باللونين البنى و الأزرق وكذلك نصوص كتابية باللون الأبيض، وقد

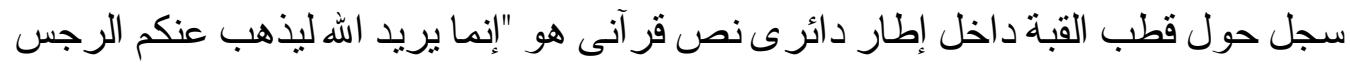

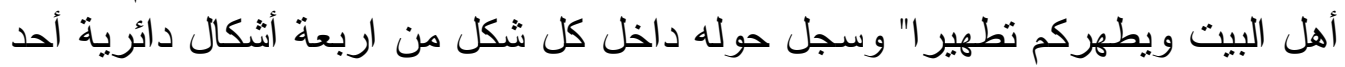

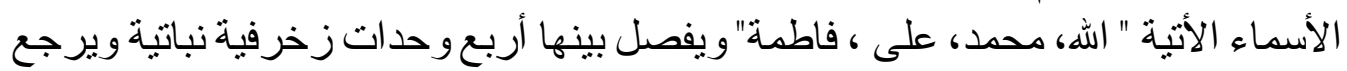

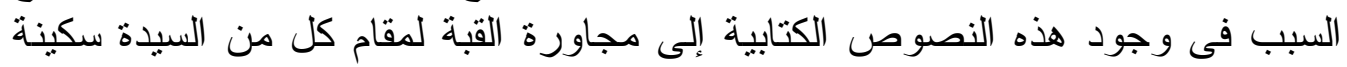

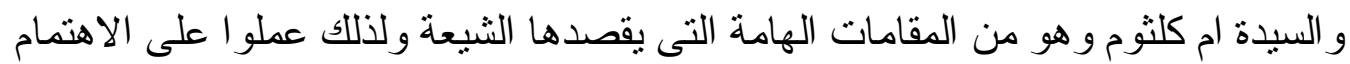

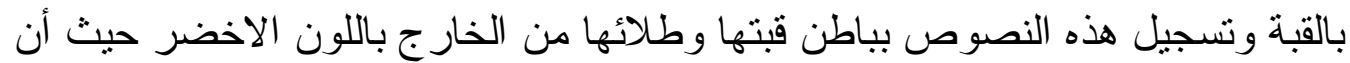

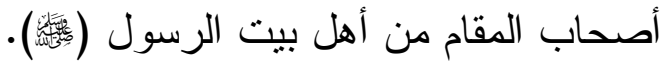

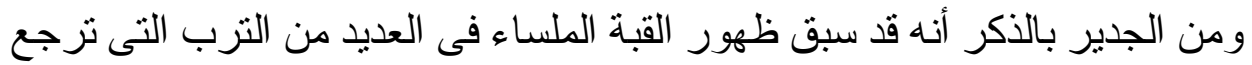

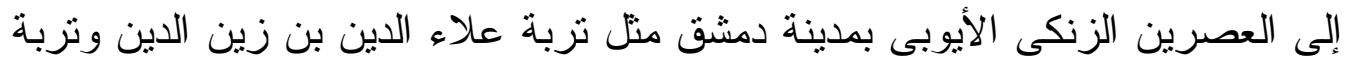

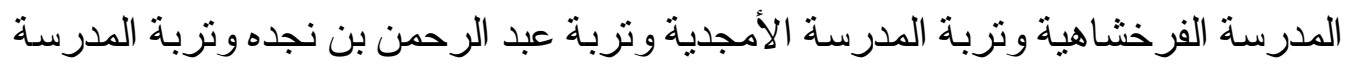

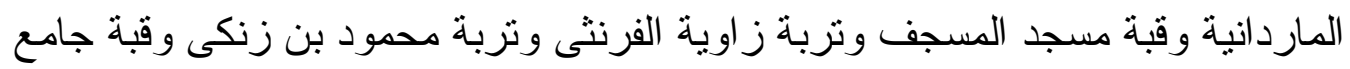

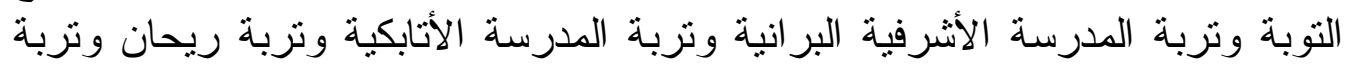
الحافظية وتربة المدرسة المرشدية وتربة المدرسة القربة القليجية و التربة القية القيمرية.

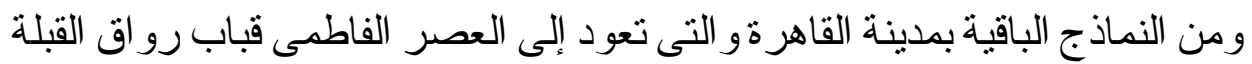

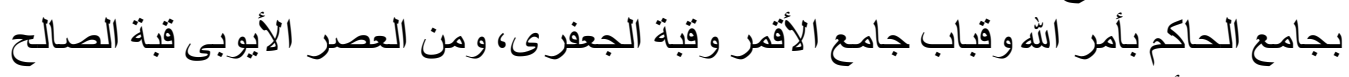

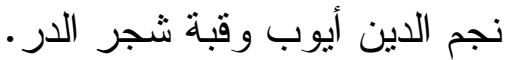

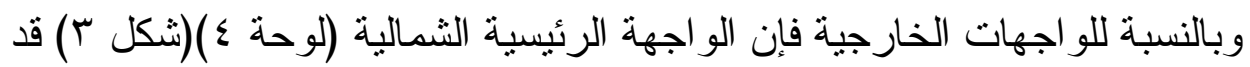

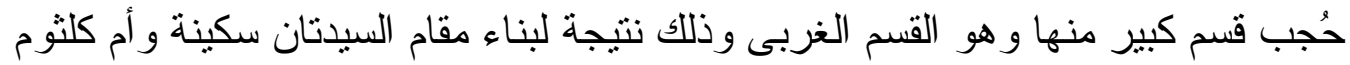

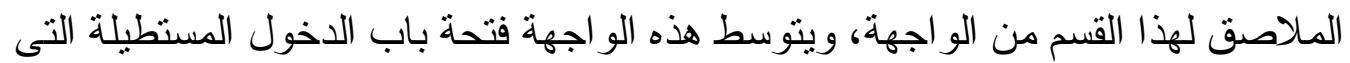

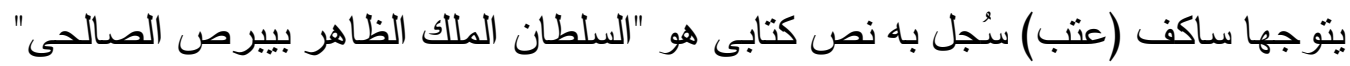

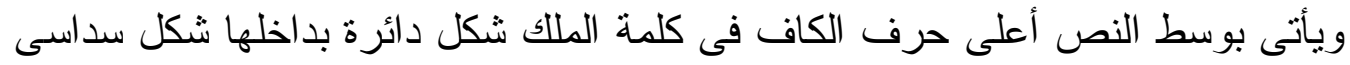

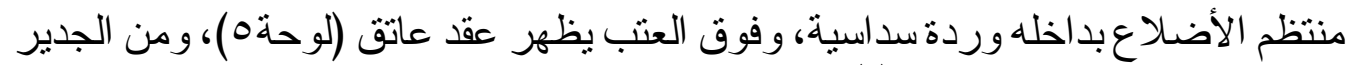

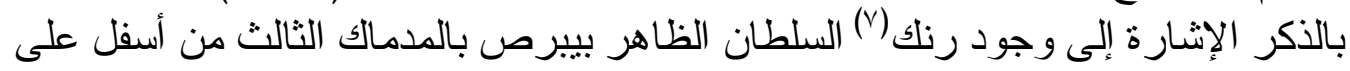

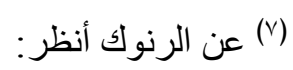

ـ أحمد عبد الر ازق: الرنوك على عصر سلاطين المماليك، المجلة التاريخية المصرية، العدد ابـ، القاهرة

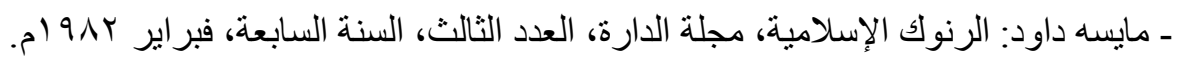

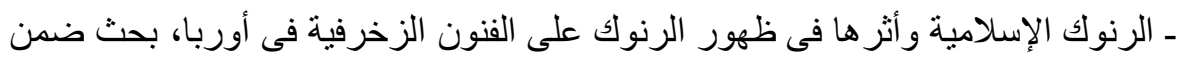


كل جانب من جانبى فتحة الباب (لوحة7) ، وتتتهى الو اجهة من أعلى بطنف (إطار)

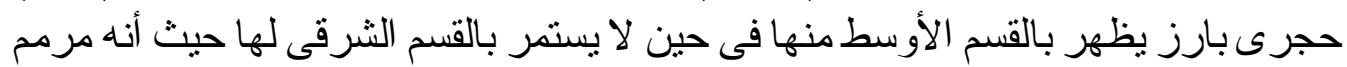

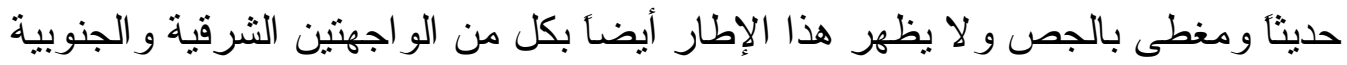

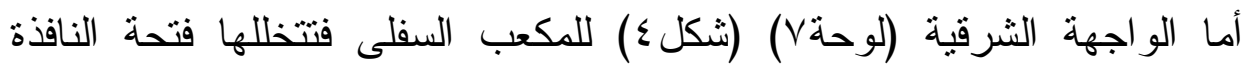

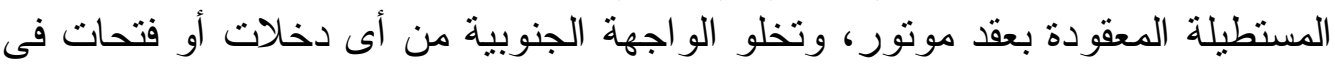

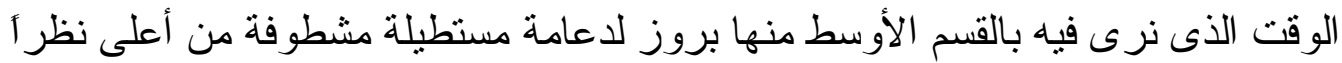

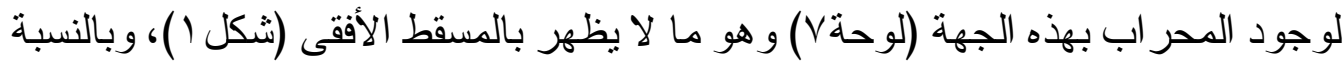
للو اجهة الغربية فقد حجبت بيناء حديث.

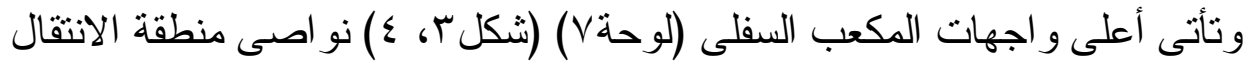

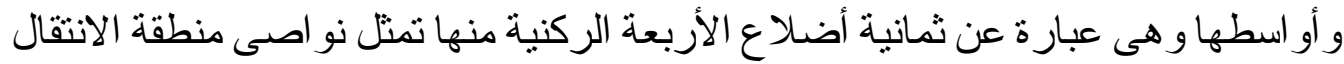

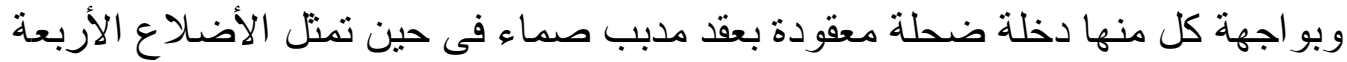

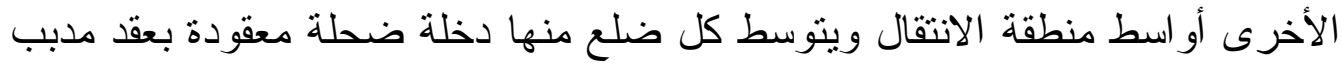

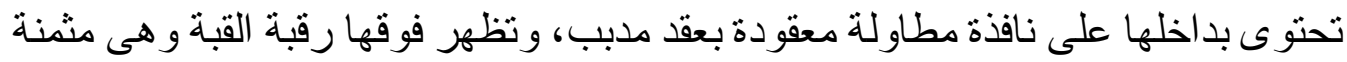

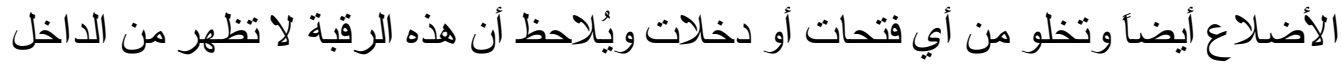

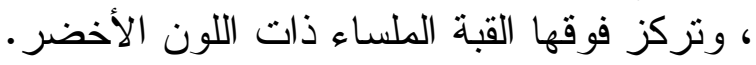

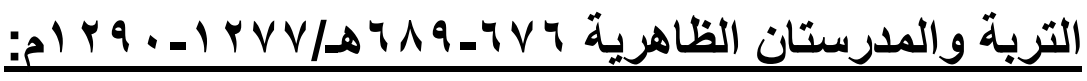 \\ الموقع:}

تقع داخل بابى الفرج و الفر اديس بينهما، جو ار الجامع (الأموي) شمالي باب البريد

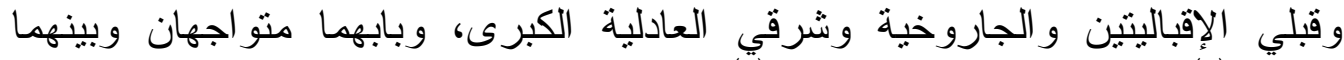

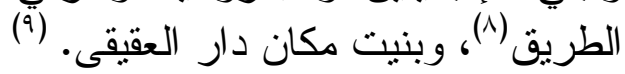

كتاب الندوة العلمية بالقاهرة (العلاقات الثقافية بين مصر وبلاد طرق الحرير) ،القاهرة ـ 99 ام.

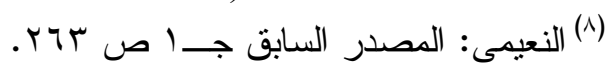
- العلموى: المصدر السابق ص

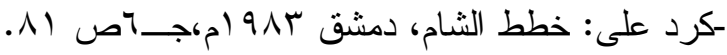

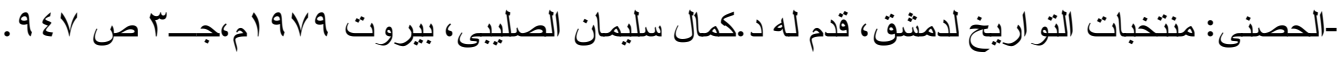

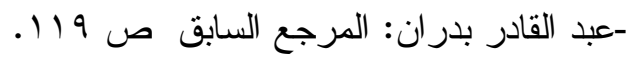

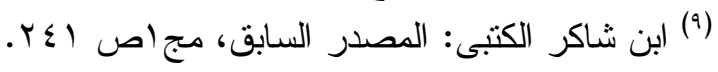




\section{المنشئ وتاريخ الإنشاء والمهنس المشرف على البناء:}

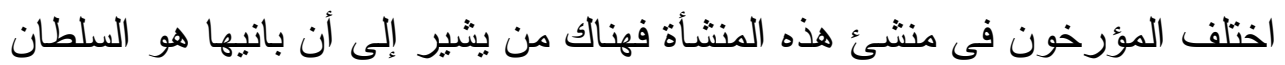

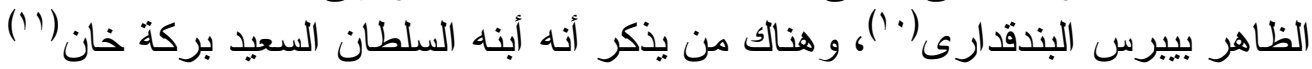

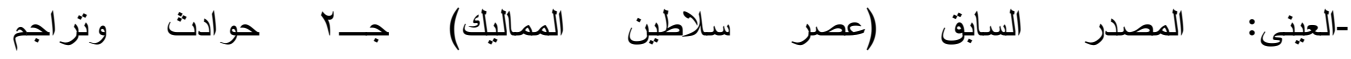

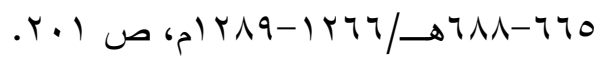

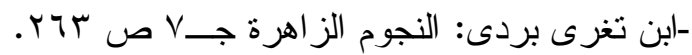

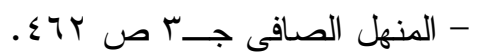

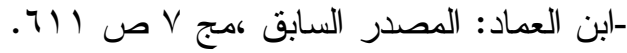

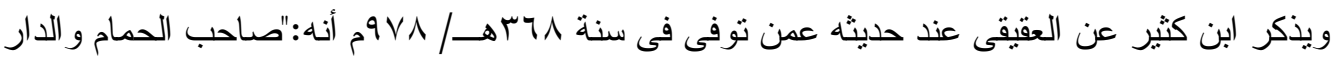

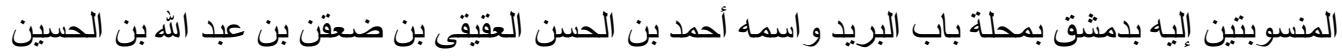

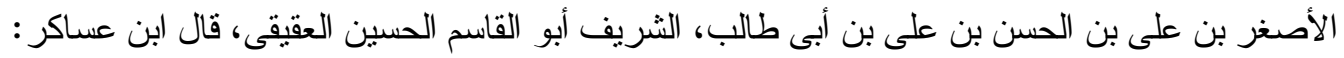

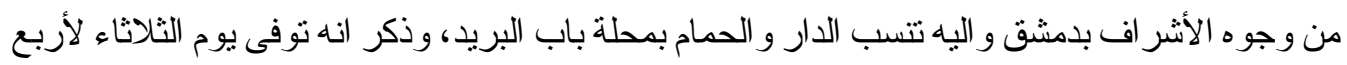

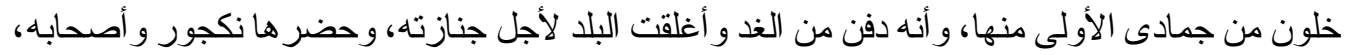

يعنى نائب دمشق ودفن خار ج باب الصغير" الابل

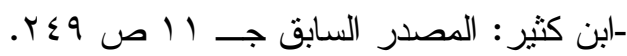

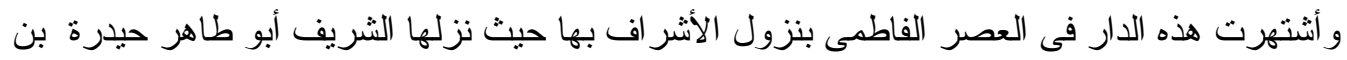

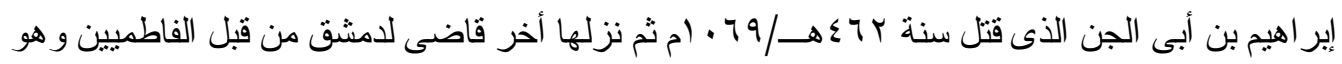

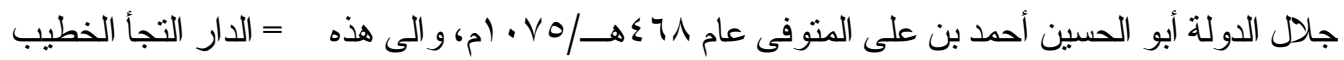

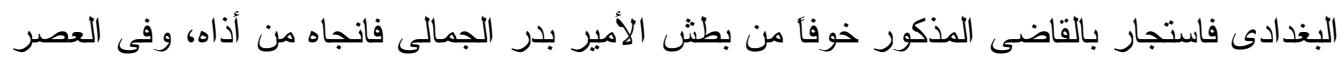

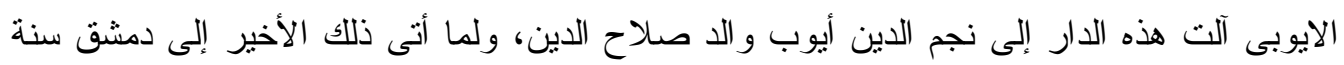

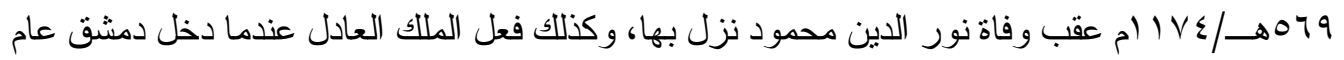

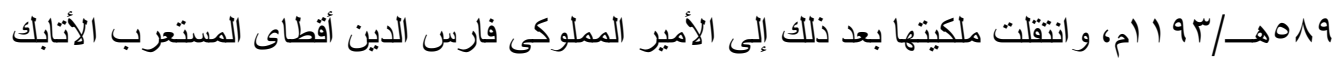

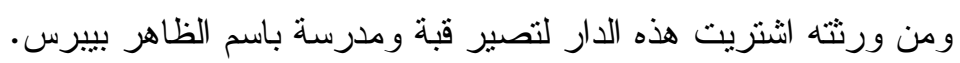

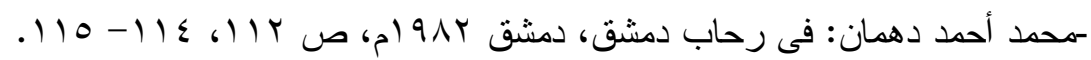

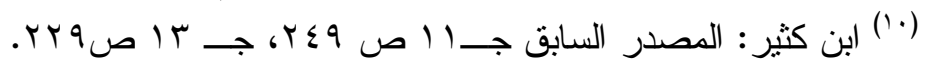

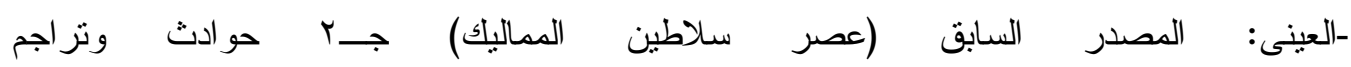
. IV9 ص ص מ

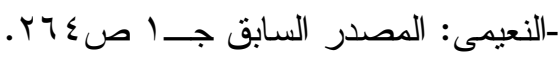


حيث أن و الده قد أوصى أن يدفن على الطريق السالكة قريباً من داريا وان يينى عليه

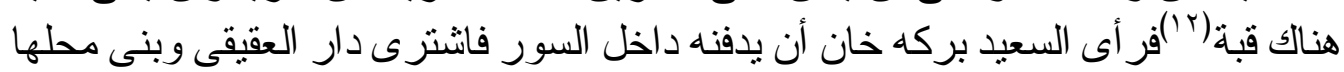

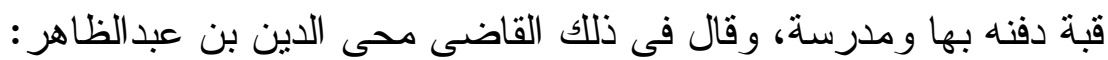

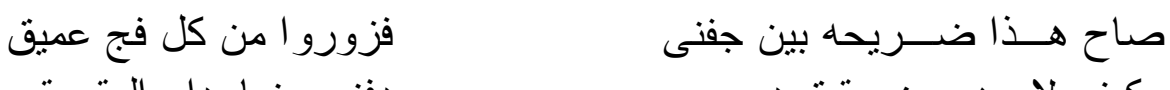

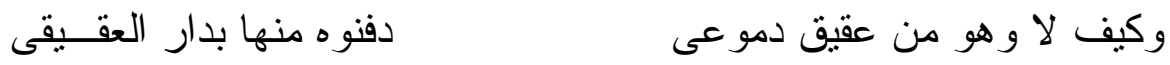

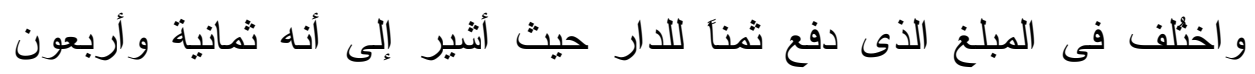

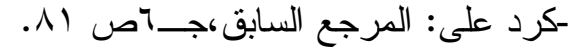

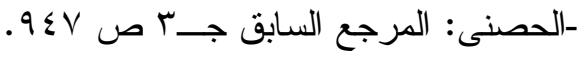

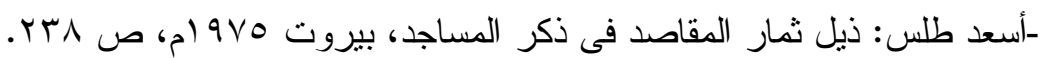

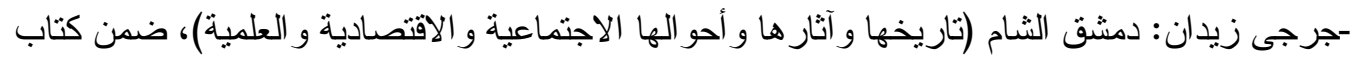

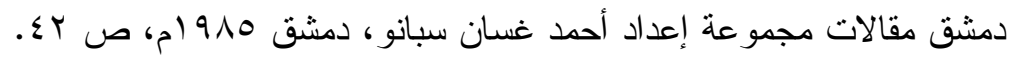

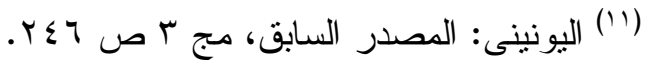

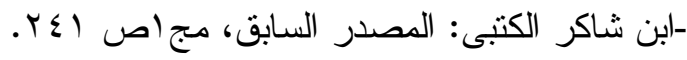

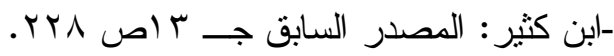
و هنا نلاحظ تتاقض ما يذكره ابن كثير حيث سبق أن أثنار إلى أن من أعمال الظاهر بييرس المعمارية

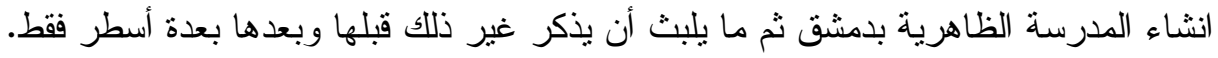

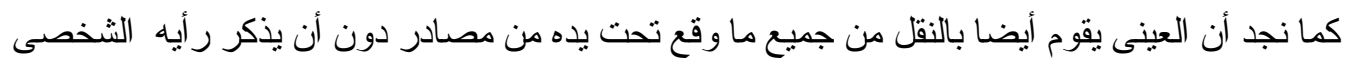

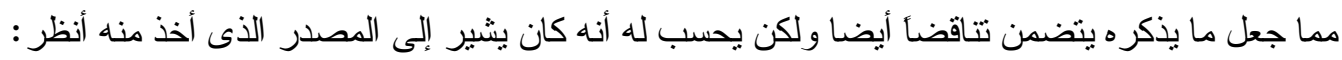

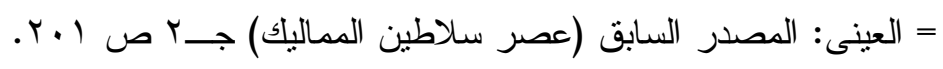

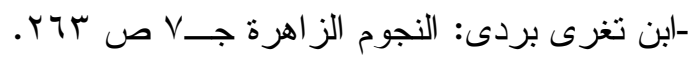

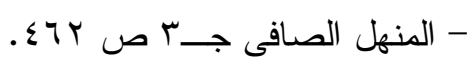
- العلموى: المصدر السابق ص -

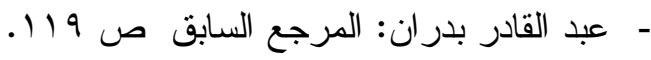

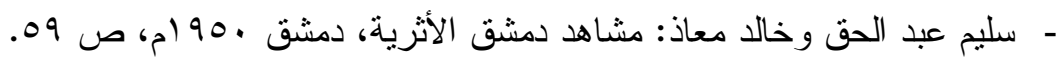

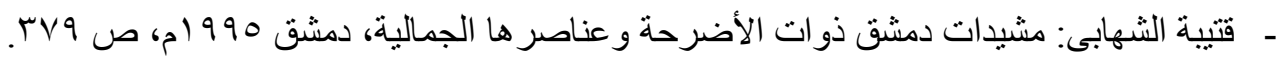

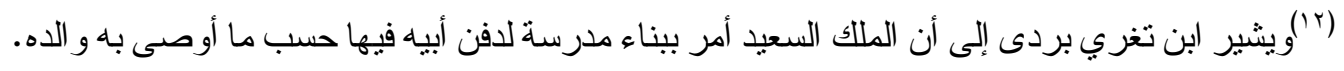

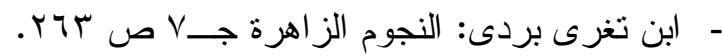

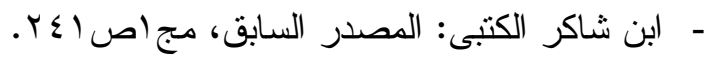




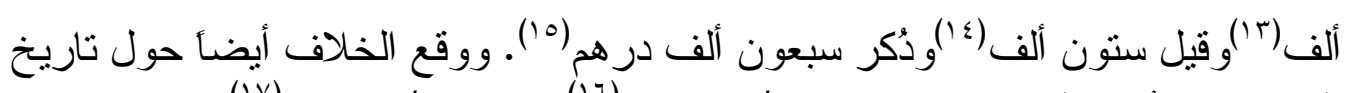

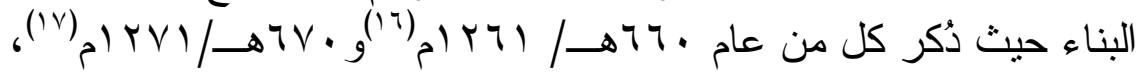

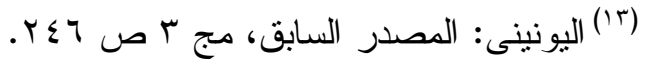

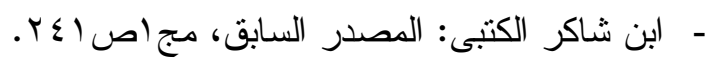

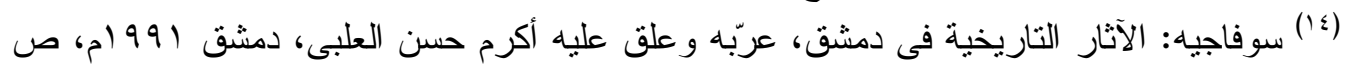

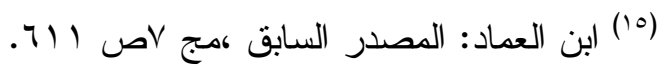

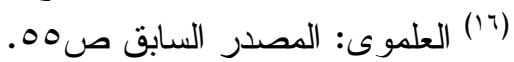

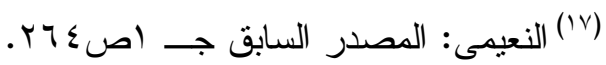




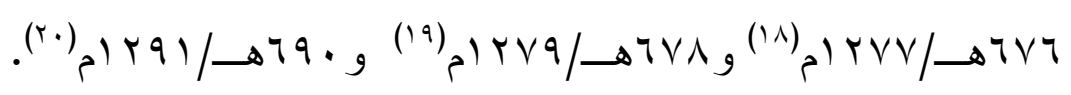

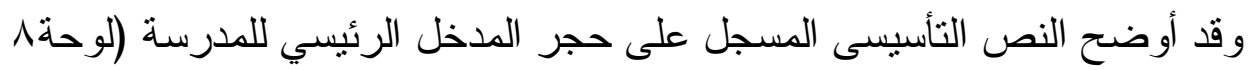

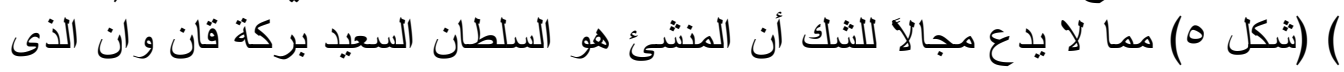

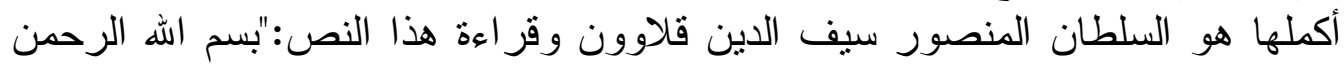

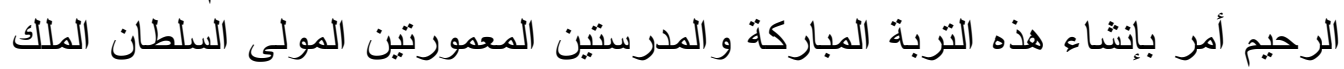

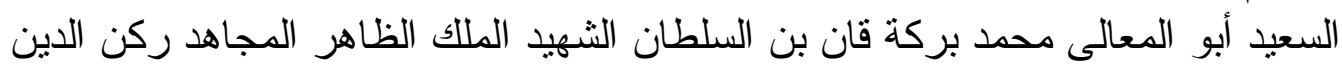

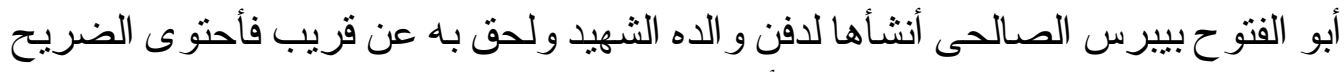

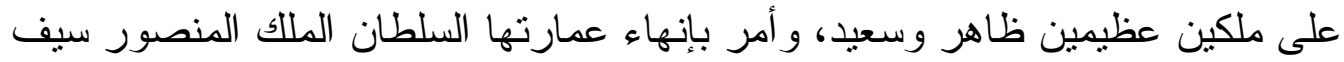
الدنيا و الدين قلاوون الصالحى قسيم أمير المؤمنين خلد الله سلطانه".

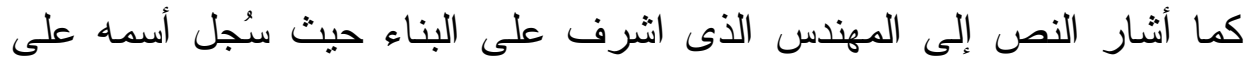

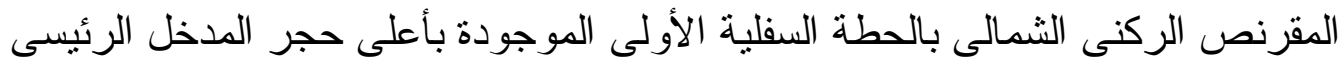

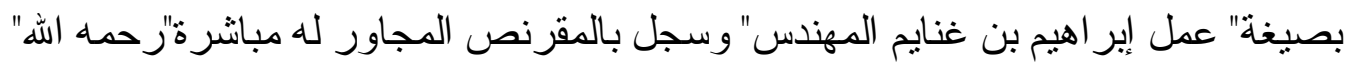

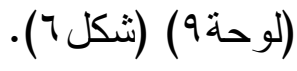

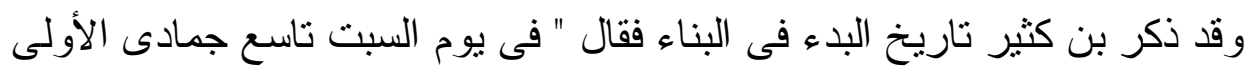

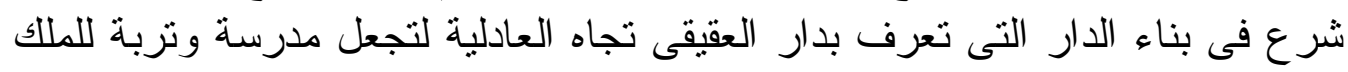

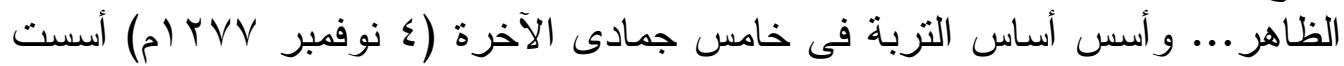

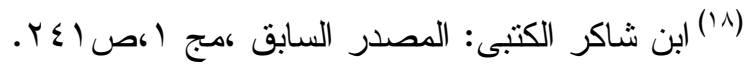

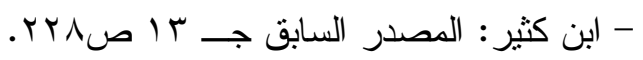$$
\text { - }
$$

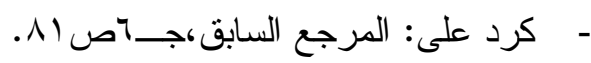

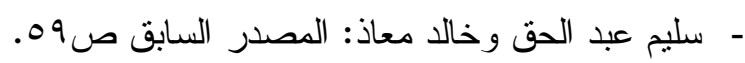

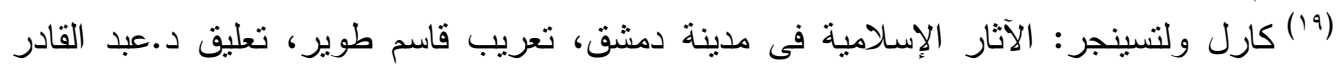

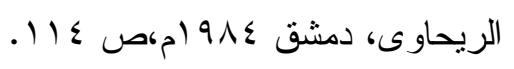

عبد القادر الريحاوى: العمارة العربية الإسلامية خصائصها وآثارها فى سورية ،دمثق 999 1م،ص

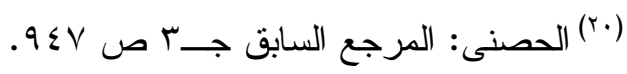




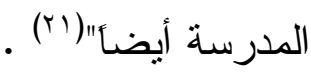

ويثير المؤرخون إلى أن الملك الظاهر نقل جثمانه إلى قبته عندما استوت وتكامل

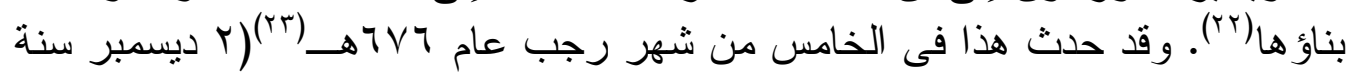
بVV

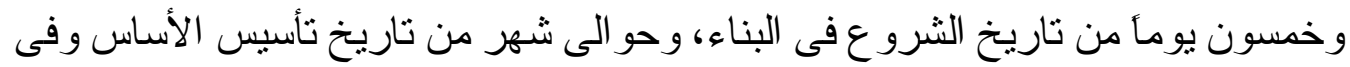

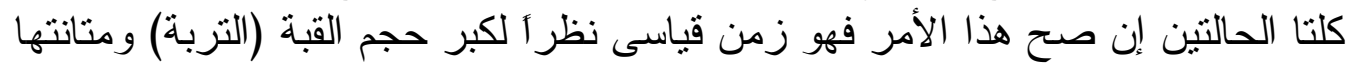
ودقة بنائها.

أما عن تاريخ الانتهاء من عمارة المبنى كله فلا يمكن إرجاعه إلى ما قبل سنة • 1 .

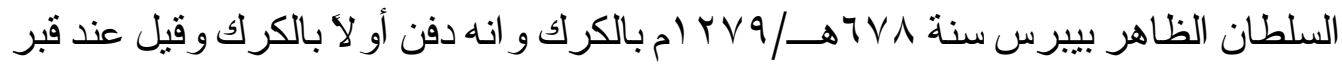

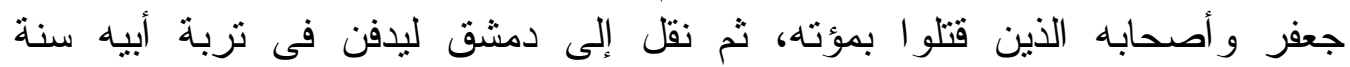

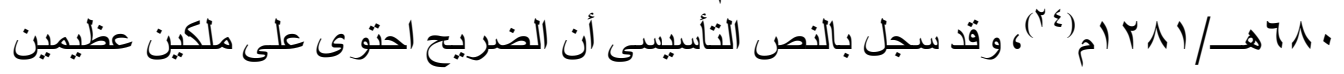

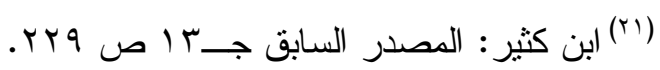

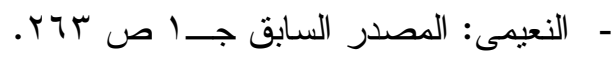

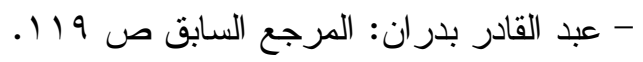

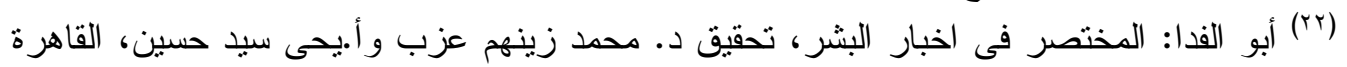

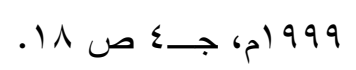

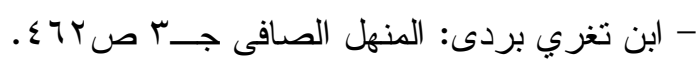

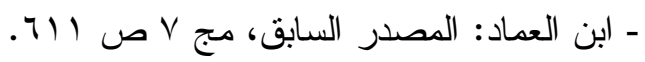

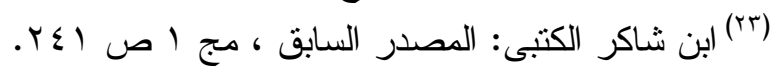

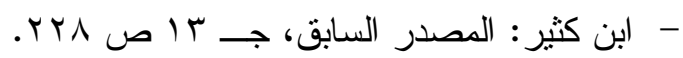

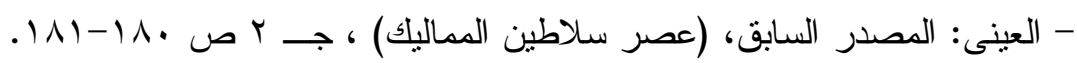

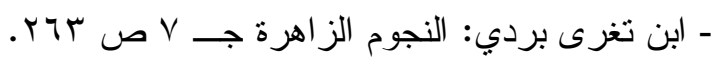

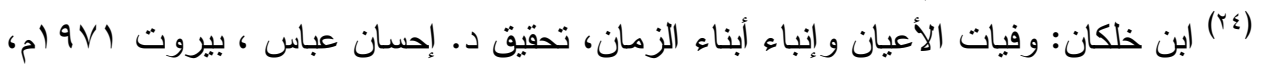

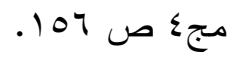

- الذهبى: العبر فى خبر من غبر ، تحقيق أبو هاجر محمد السعيد بن بسيونى زغلول ، بيروت 910 (م، جדr ص q"זr. 


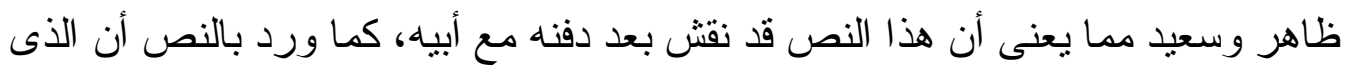

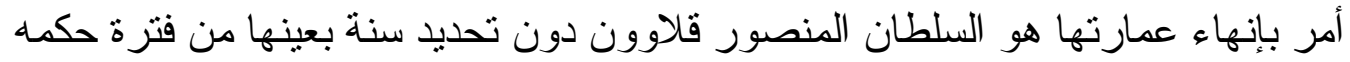

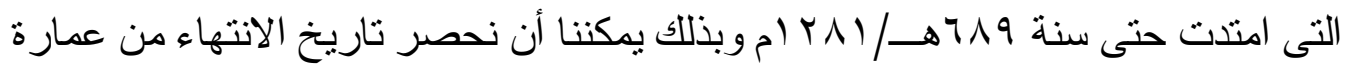

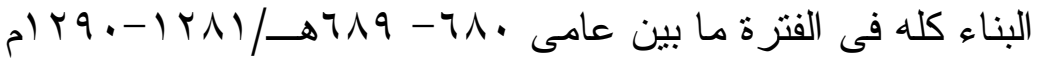

\section{أوقاف المدرسة ومخصصات العاملين بها:}

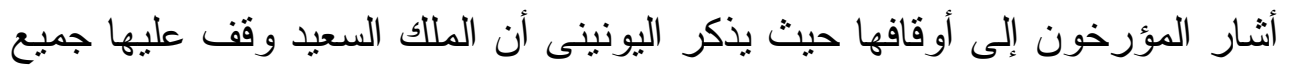

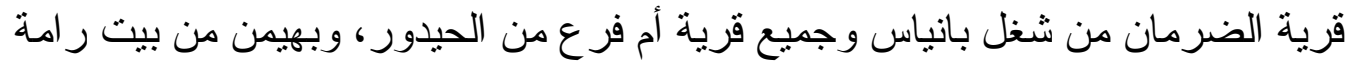

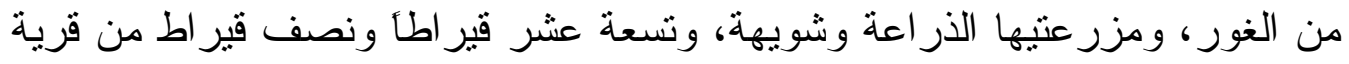

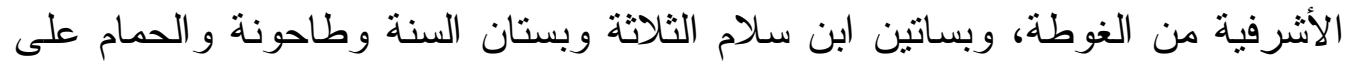

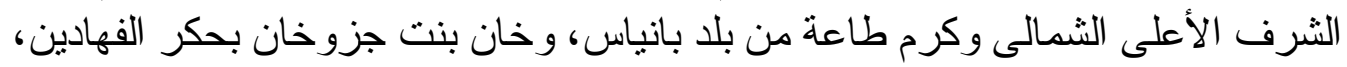

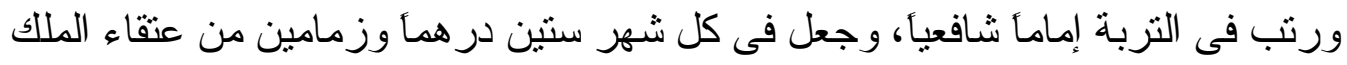

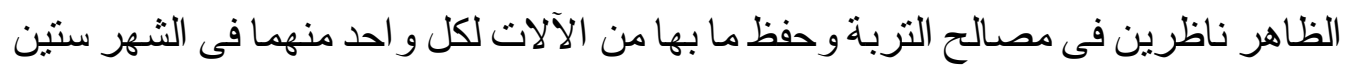

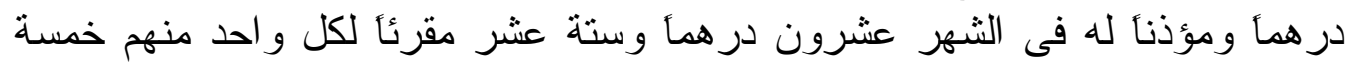

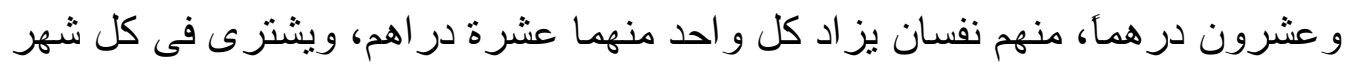

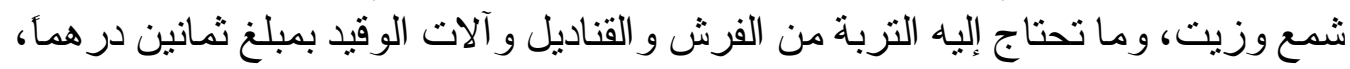

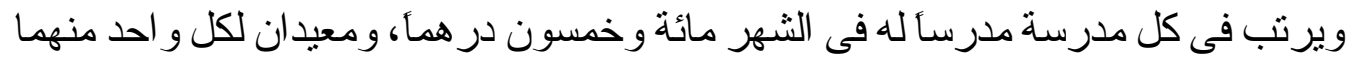

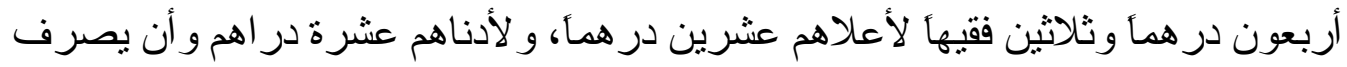

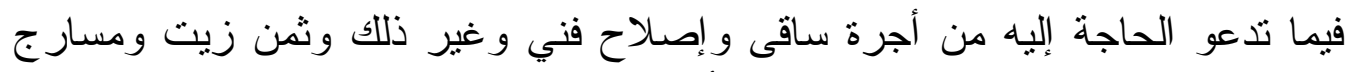

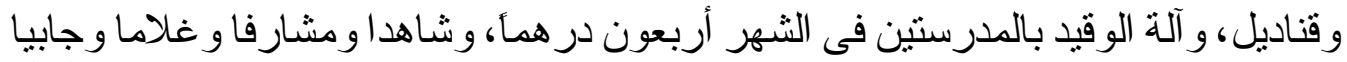

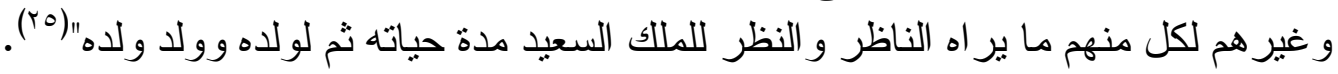

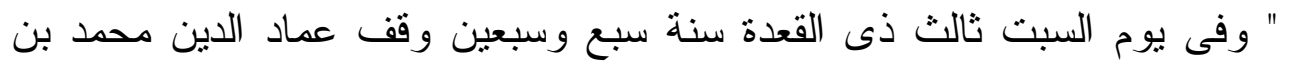

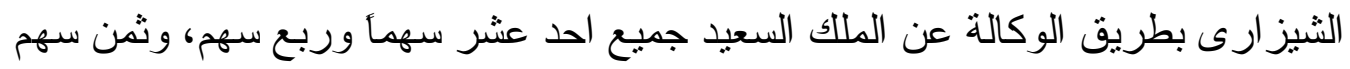

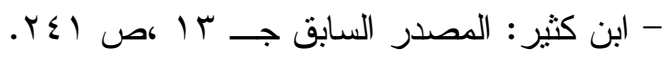

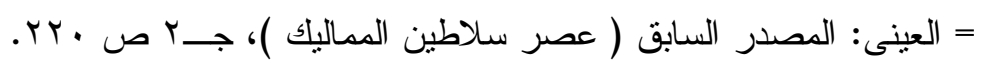

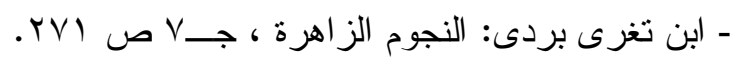
(ro) 
من قرية الطرة من ضياع الجبيل من إقليم اذر عات من عمل دمثق إلى المدرستين و التربة،

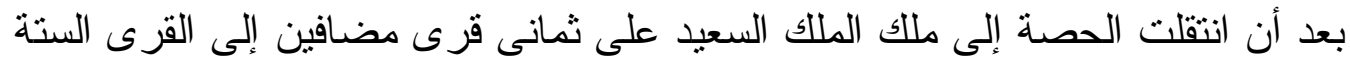

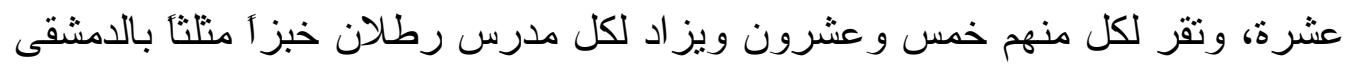

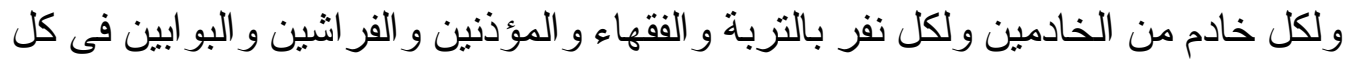

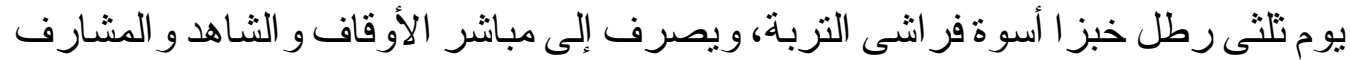

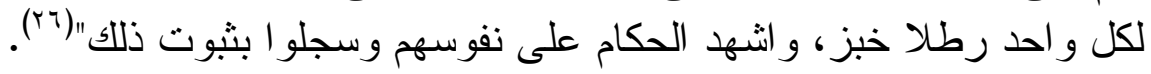

ويثير النعيمى إلى الأوقاف بقوله"ومن وقف هذه المدرسة الحصص بالقنبطرة، ثم كفر

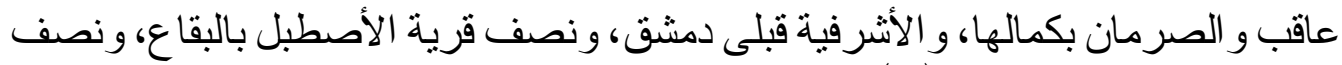

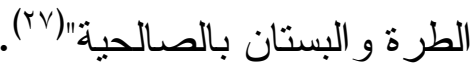

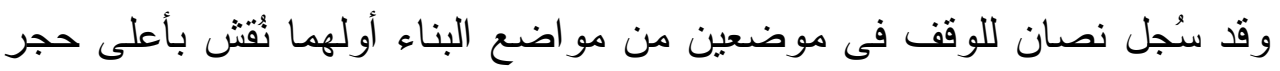

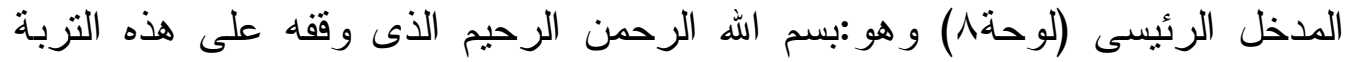

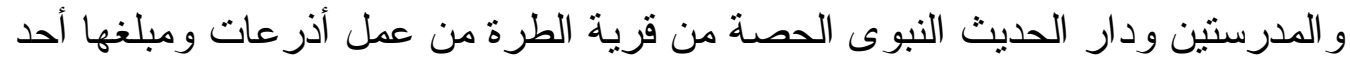

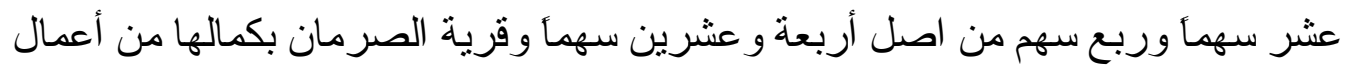

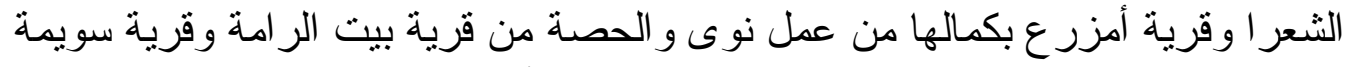

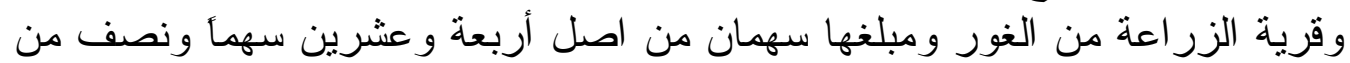

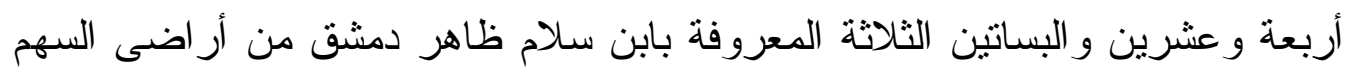

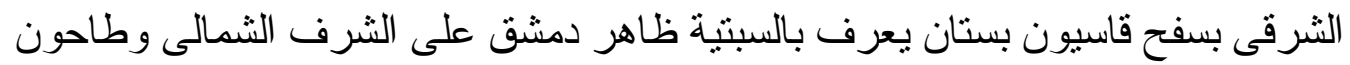

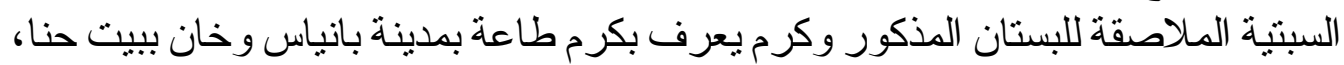

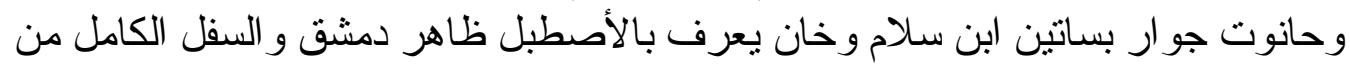
قبسارية الثرب وذللك فى سنة ست وسبعين وستماية".

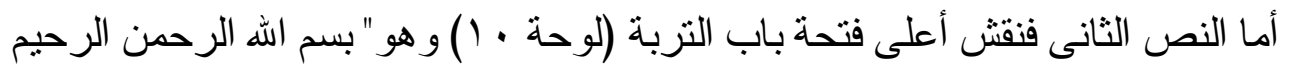

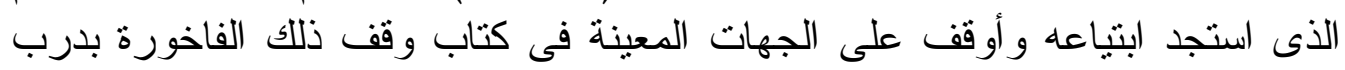
الفو اخير و البيوت طباقها و الحصة من قرية صهيا ومبلغها ثلثى ثمن سهم من أربعة

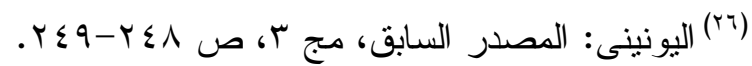

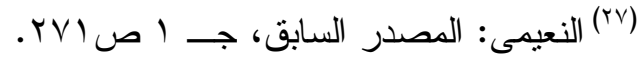

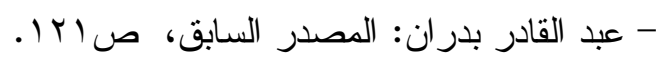


و عشرين، الاهر اء الثلاثثة وطباقها بالمربعة، الحصة من قرية الأصطبل بالبقاع العزيزى

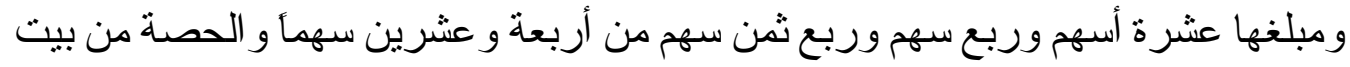

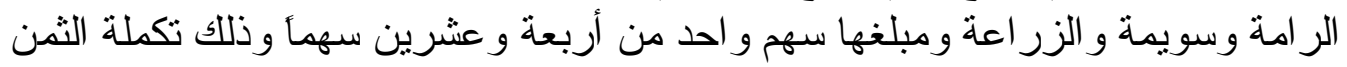
من القرية المذكورة"ا.

ويشير ابن طولون إلى التلاعب فى أوقافها حيث يذكر فى حو ادث شهر جمادى الآخرة

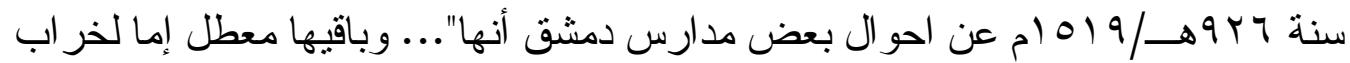

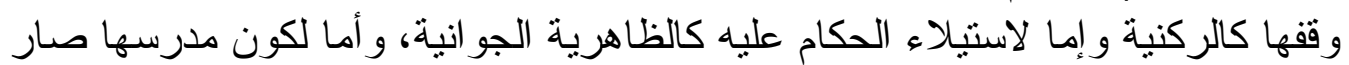

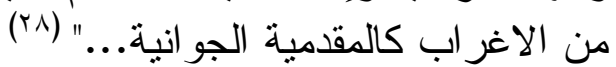

\section{التطورات التحى لحقت بالمنشأة :}

يذكر اليونينى أن الملك السعيد أوقف المدرسة المذكورة و القبة مدفنأ وباقيها مسجداً لله تعالى برسم الصلو ات وقر اءة القرآن العزيز و الاعتكاف، وباقى الدار مدرستين إحداهما

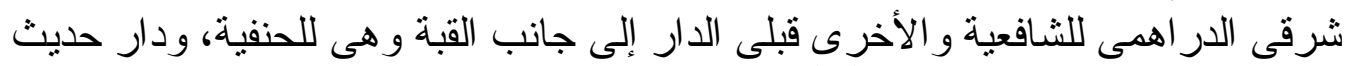
قبلى الإيو ان المختص بالثـافعية(r9).

ويشير ابن تغرى بردى إلى أن دار العقيقى هُدمت وبنى موضع بابها قبة الدفن وفتح

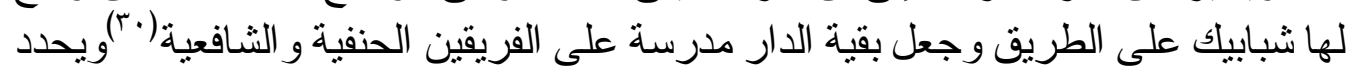

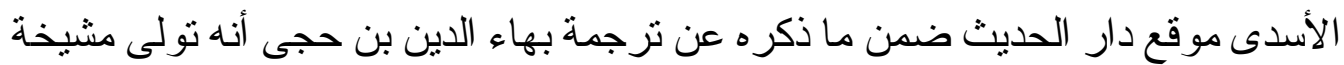

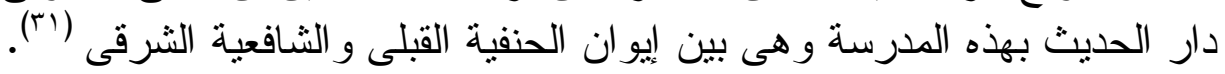

وفى يوم الأربعاء ثالث عشر صفر عام TVVهـ الموافق السادس من يوليو سنة

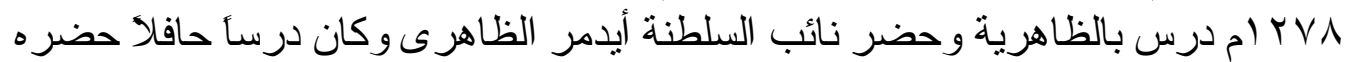
القضاة وكان مدرس الثافعية الثيخ رشيد الدين الفارقى ومدرس الحنفية الثيخ صدر الثين الدين

$$
\begin{aligned}
& \text { (ابن طولون: (rN) }
\end{aligned}
$$

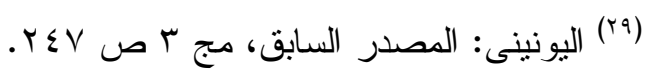

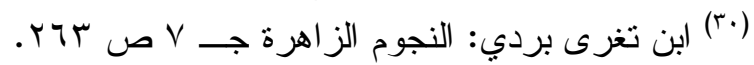

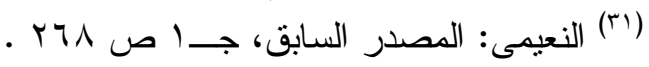


سليمان، ولم يكن بناء المدرسة قد كمل(rr).

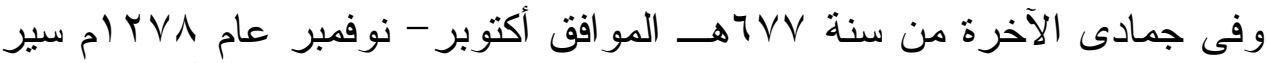

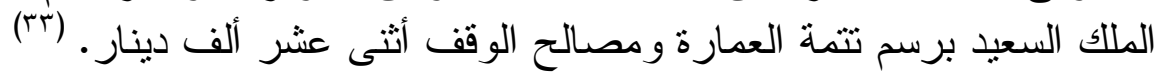

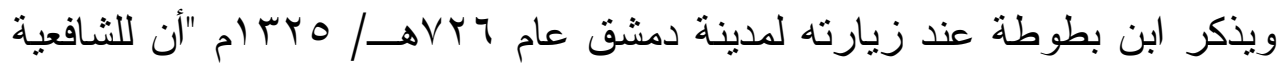

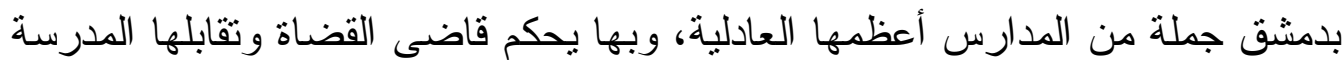

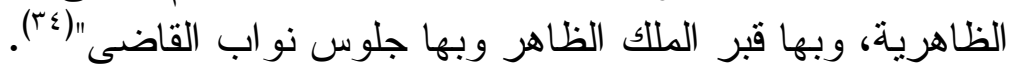

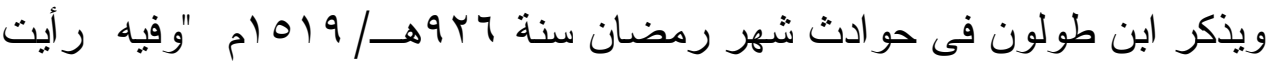
الظاهرية الجو انبة كلها قد كلست وذهب فبر ونبر و اقفها، فعل ذلك النائب لاستيلائه على أحسن

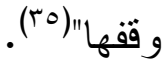

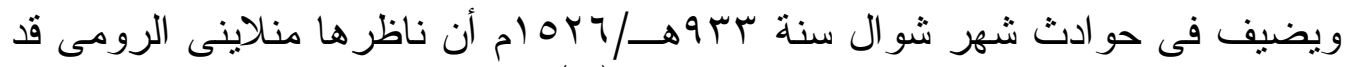

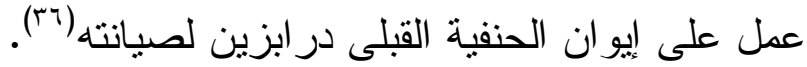

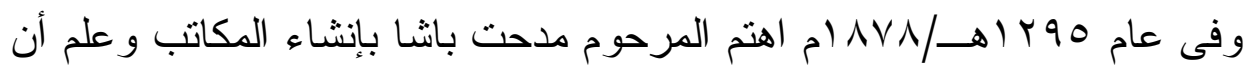

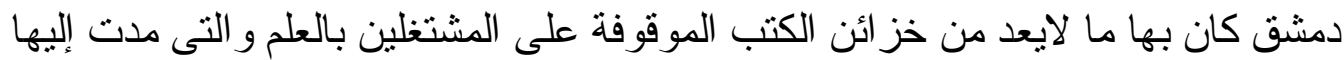

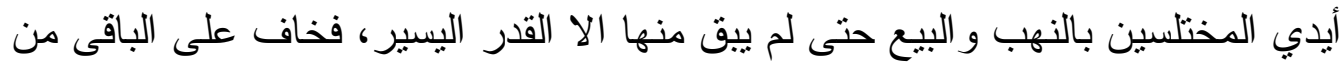

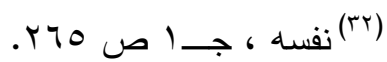

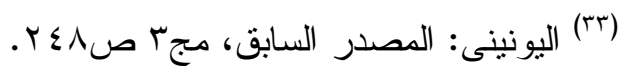

(1) ابن بطوطه: تحفة النظار فى غر ائب الأمصار ، شرحه وكتب هو امشه طلال حرب، بيروت د.ت،ص

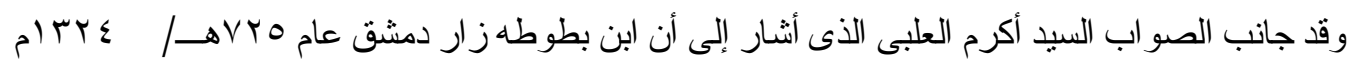

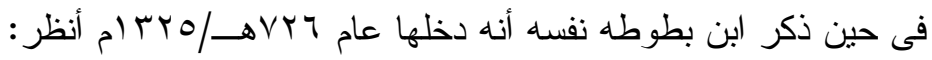

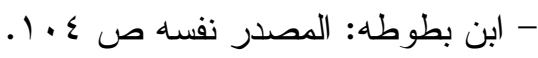

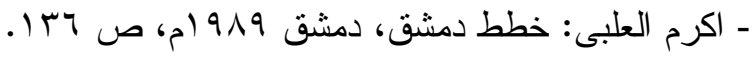

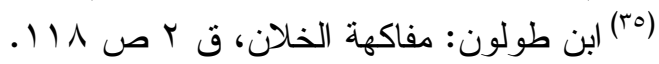

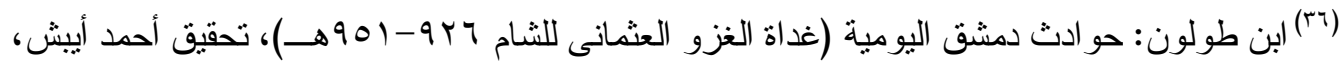

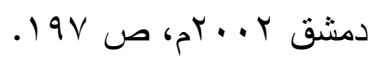




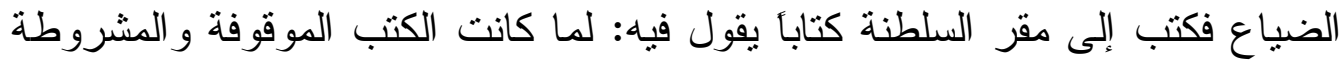

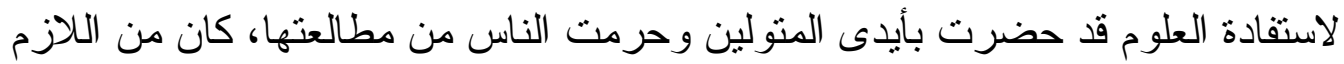

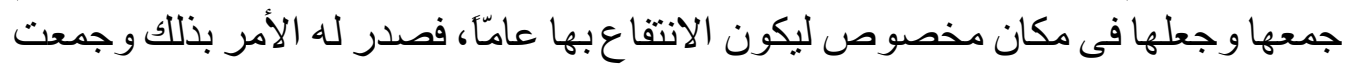

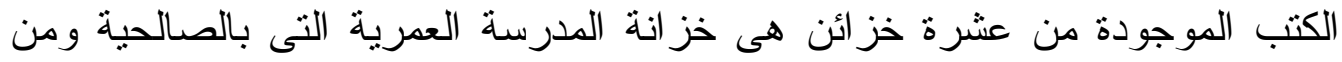

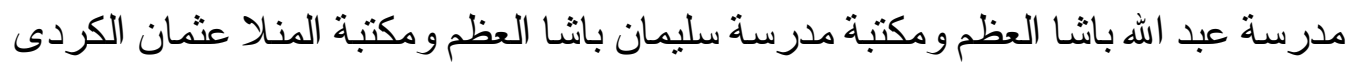

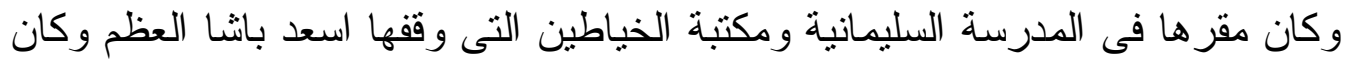

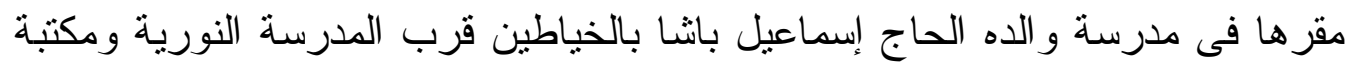

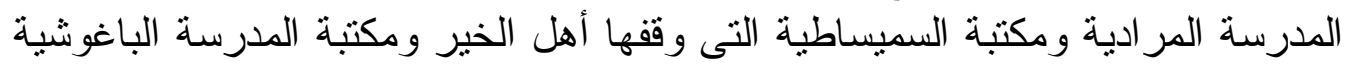

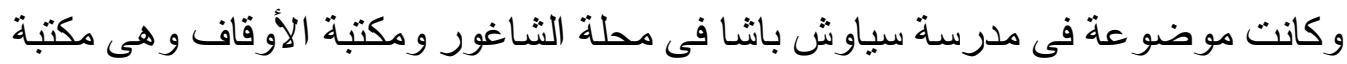

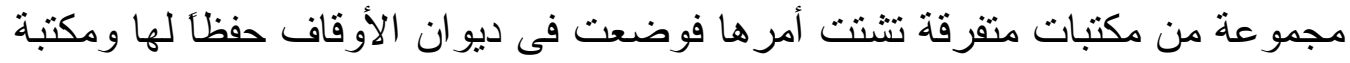

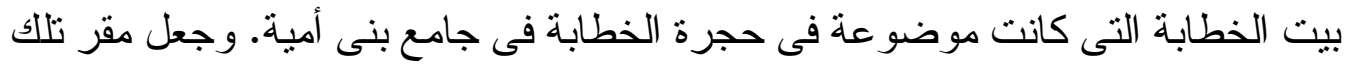

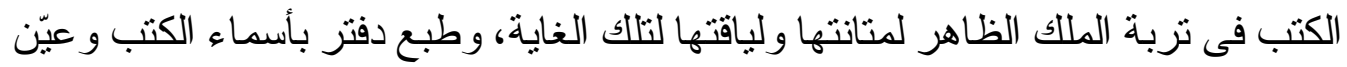

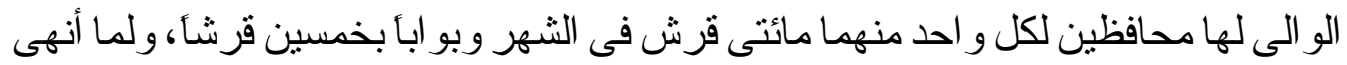

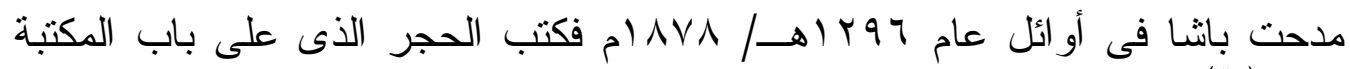
باسمة (rv) (rv)

ويصفها بدران أيضا بقوله:" أن هذه باقية إلى الآن وهى مشهورة معروفة وبابها

$$
\text { (القبر }
$$

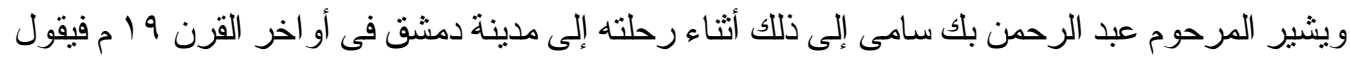

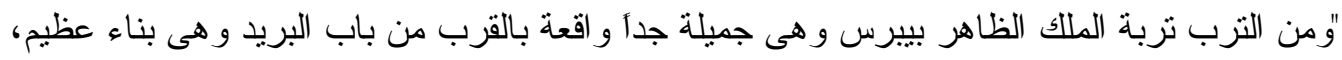

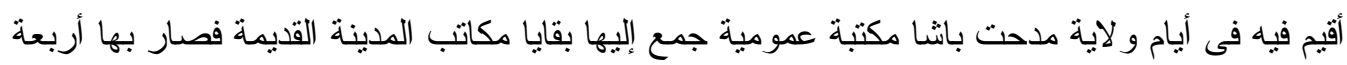

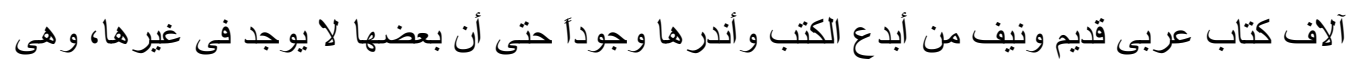

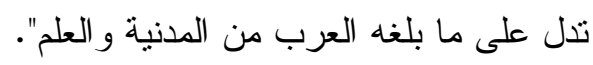

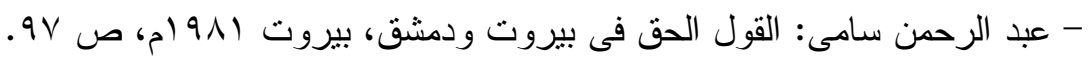

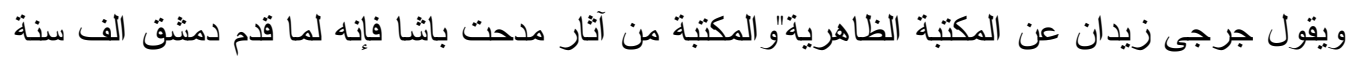

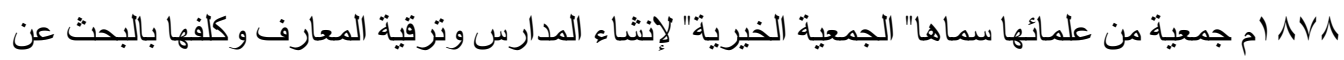

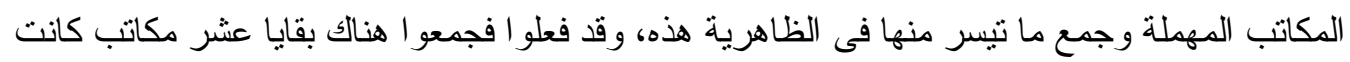

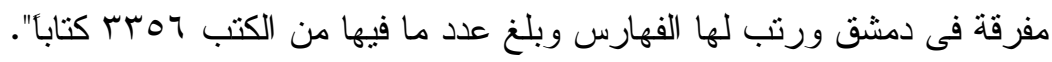

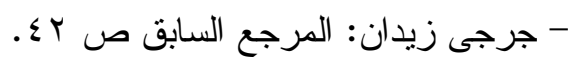




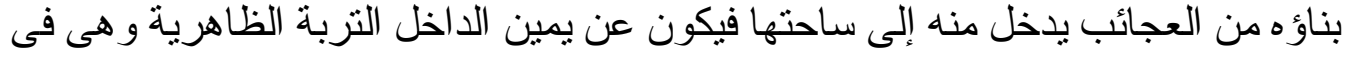

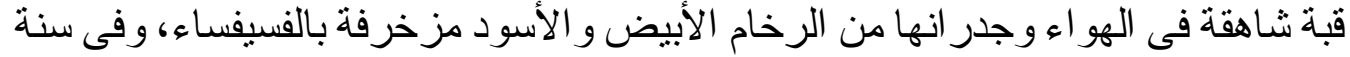

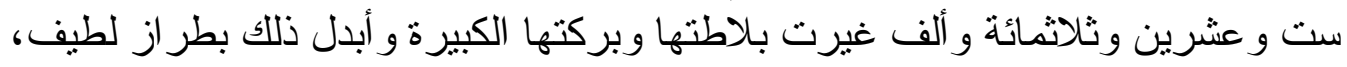

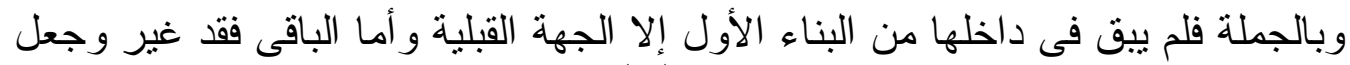

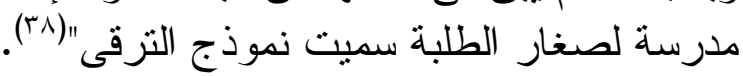

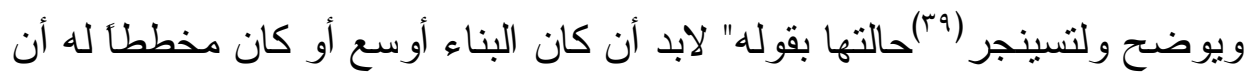

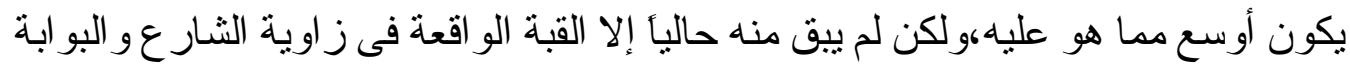

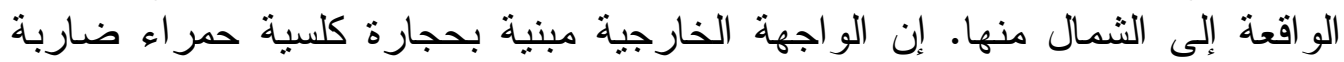

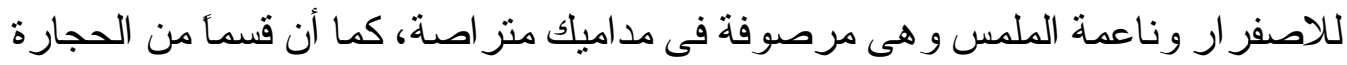

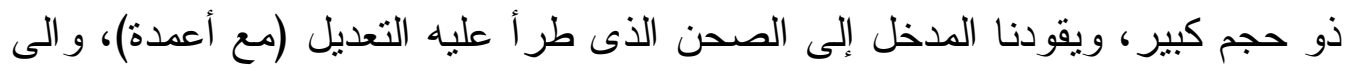

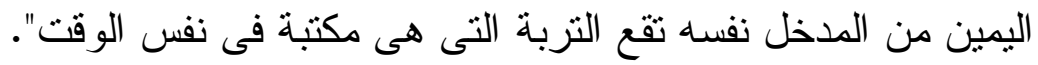

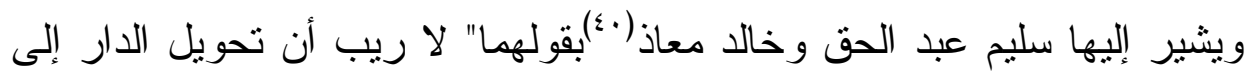

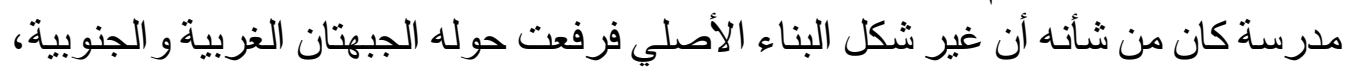

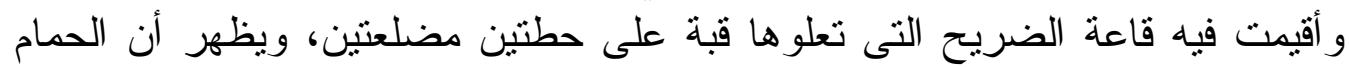

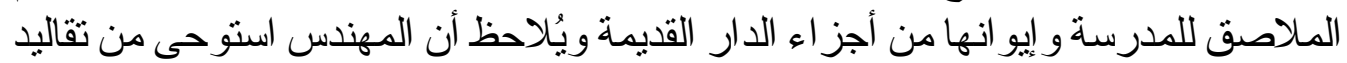

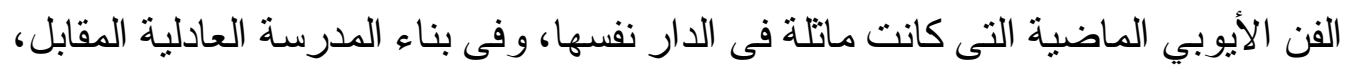

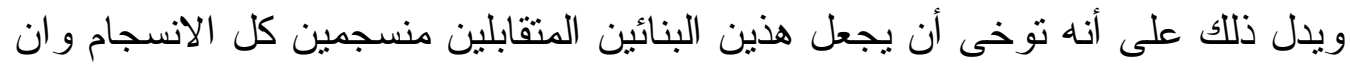

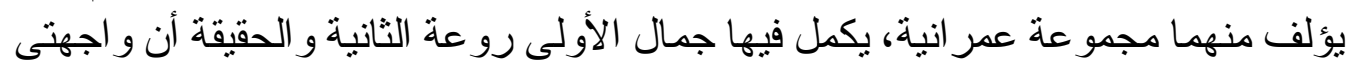

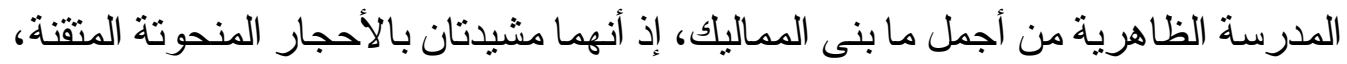

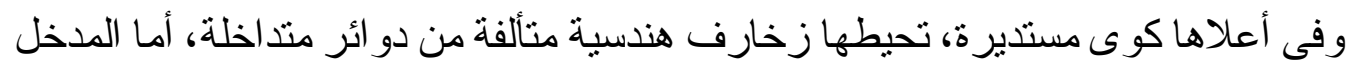

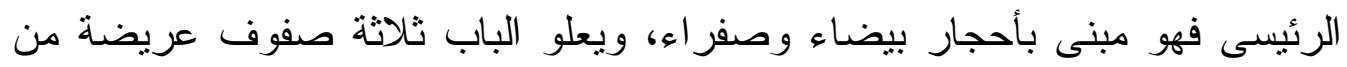

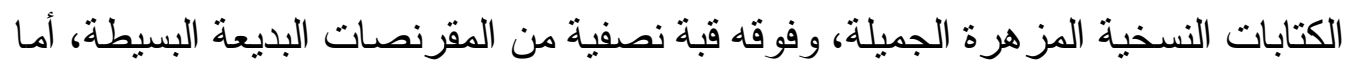

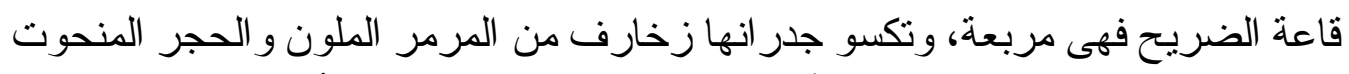

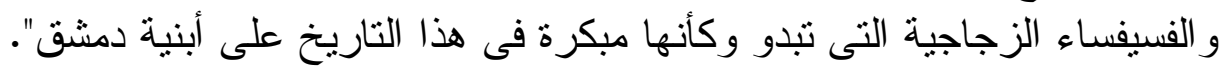

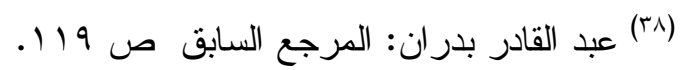
|

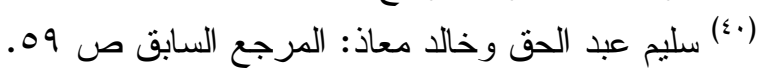




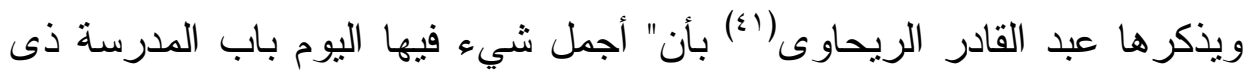

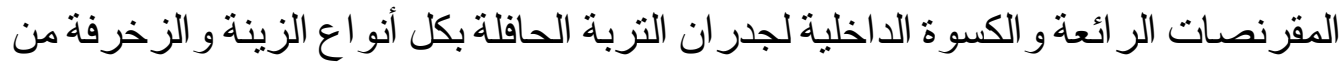

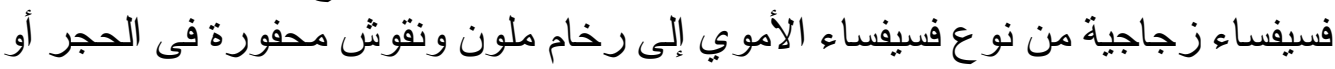

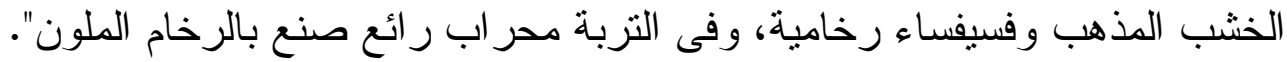

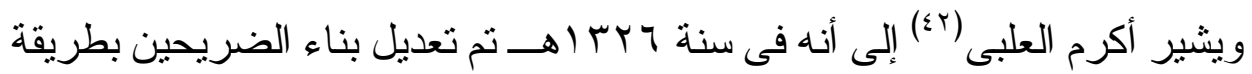
سمجة ومرتجلة فجاء طول الضريح ثلاثة أمتار و هو خال من كل لمحة فنية على الإطلاق.

\section{المدفونان بالتربة:}

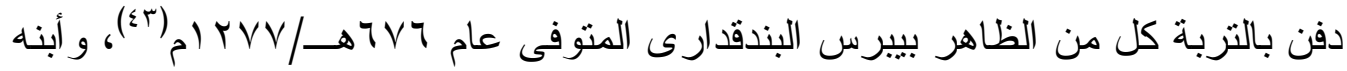

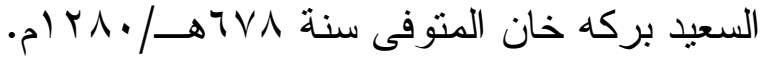

\section{ترجمة الملك السعيد بركة خان: (๕؛)}

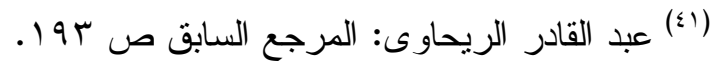

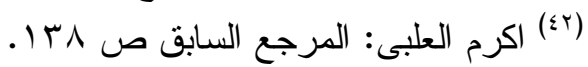

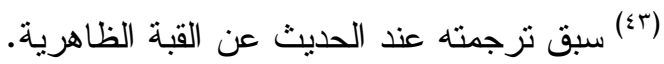

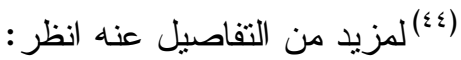

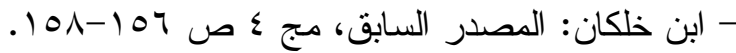

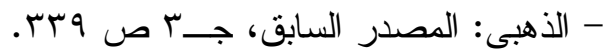

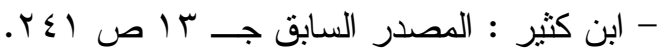

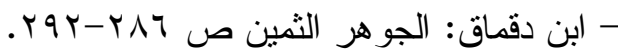

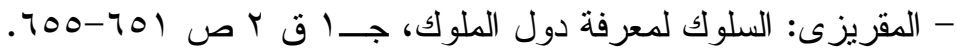

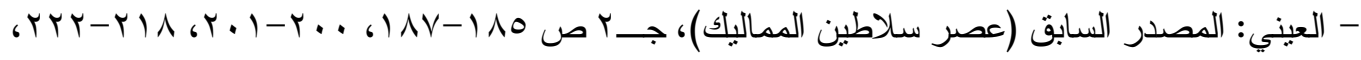
trut

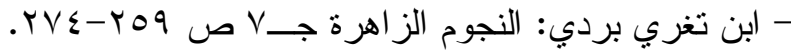

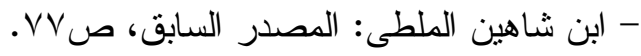

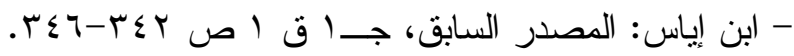

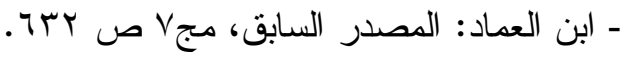


السلطان الملك السعيد ناصر الدين أبو المعالى محمد المدعو بركة خان بن السلطان الملكي

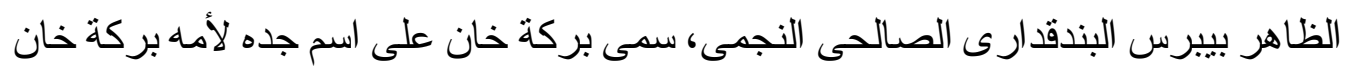

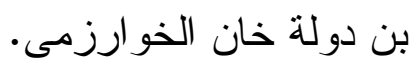

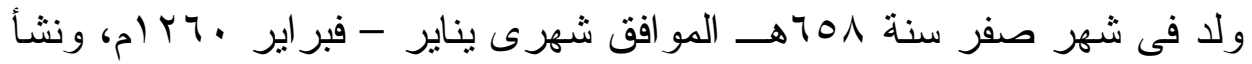

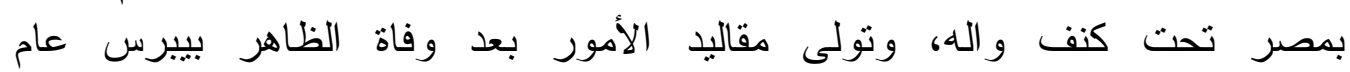
ITVV/ TV TVT

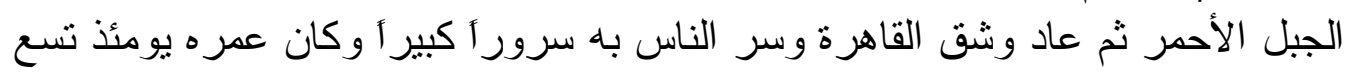

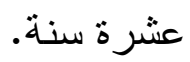

وخرج السلطان السعيد بركة خان من مصر فى العشر الأو اسط من ذى القعدة سنة

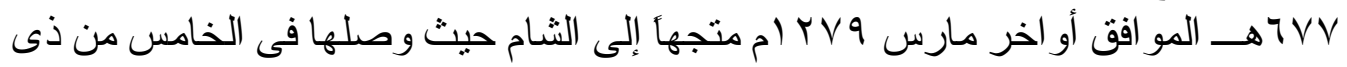

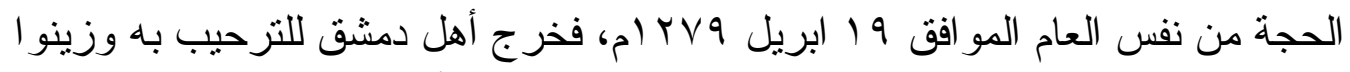

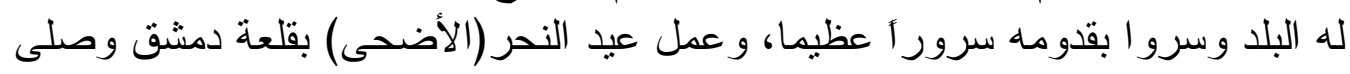

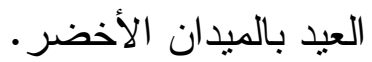

ثم جهز السلطان الجيش للخروج إلى بلاد سيس ومقدمه الأمير سيف الدين قلاوون

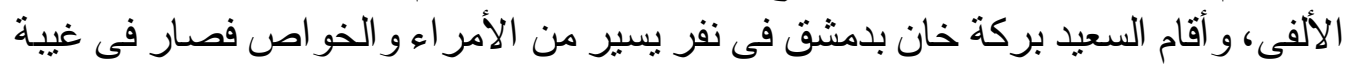

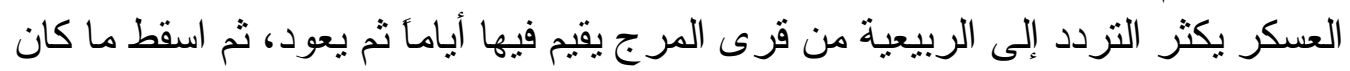

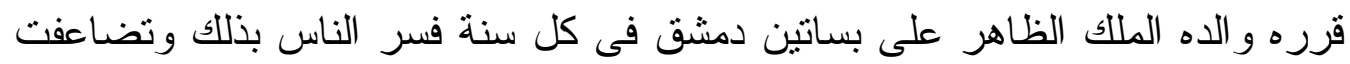

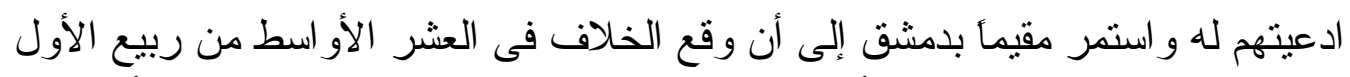

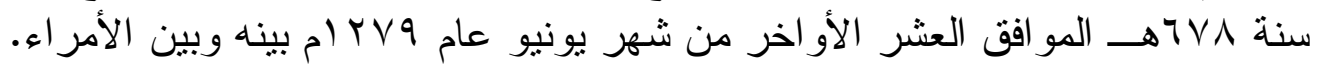

ويرجع السبب فى ذلك إلى أن السلطان أكثر من عطاياه و إنعاماته على الخاصكية

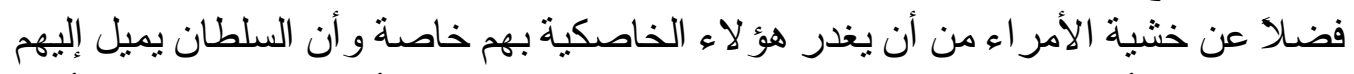

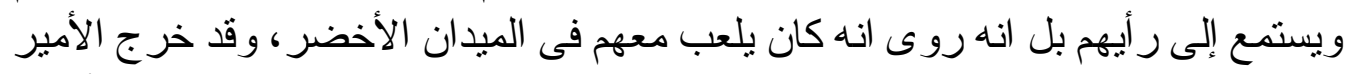

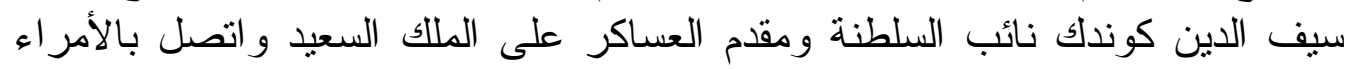

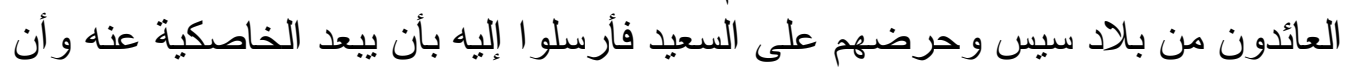

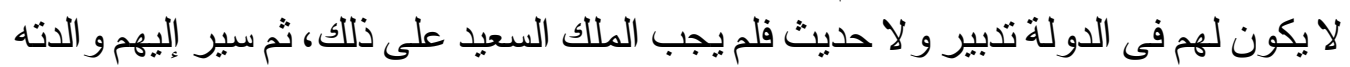

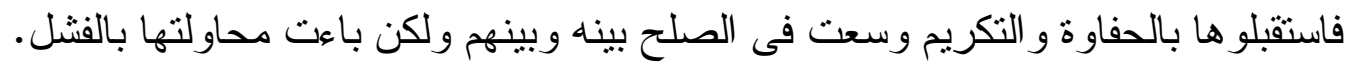




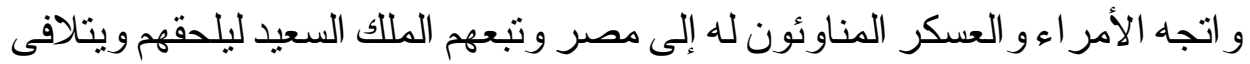

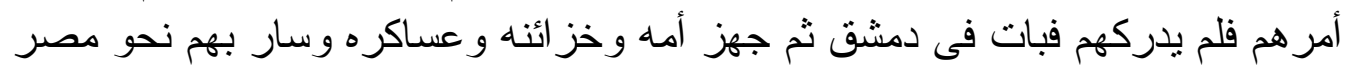

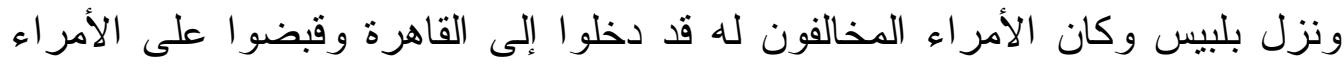

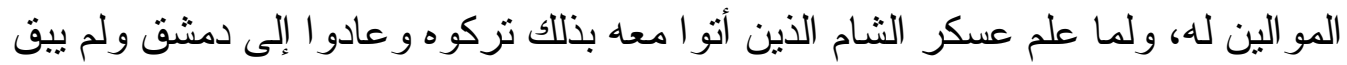

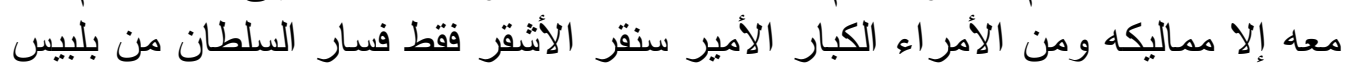
ففارقه سنقر الأشقر عند المطرية و أقام هناك. الأك.

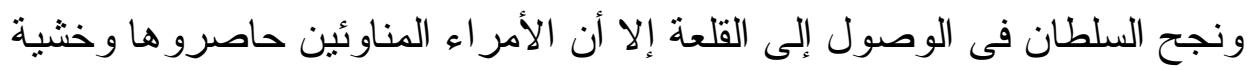

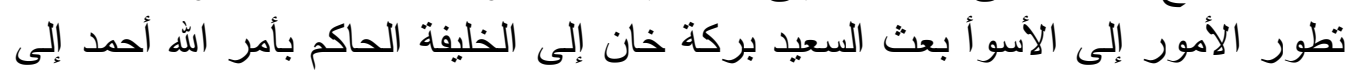

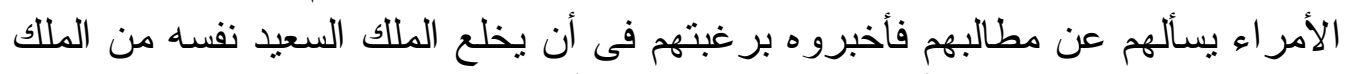

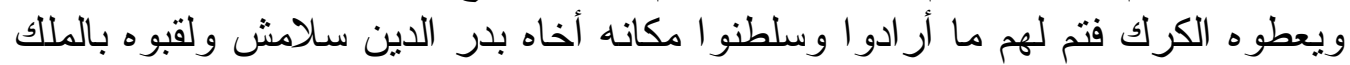

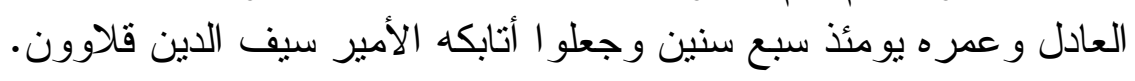

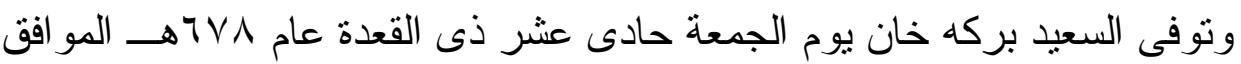

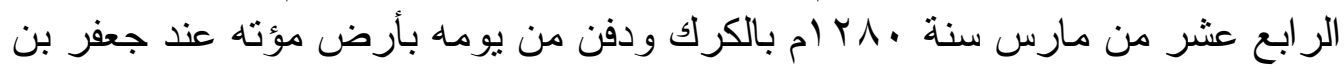

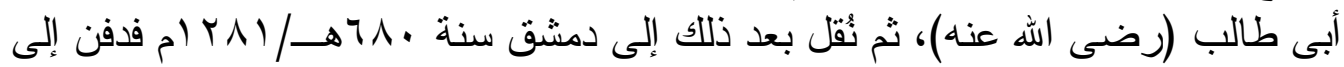

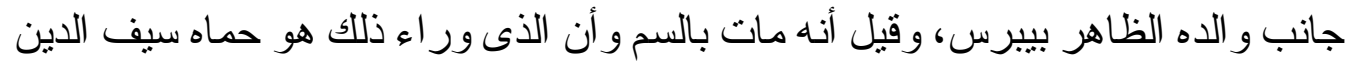
قلاوون الذى استوحش منه ننتجة لإكثار السعيد بركة خان النيان من استخدام المماليك وكثرة

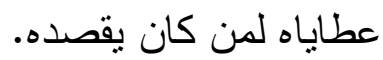

\section{الوصف المعمارى (الأشكال V-9):}

تتألف الددرسة من صحن أوسط مستطيل كثف سماوى اظهر المسقط الأفقى الأول

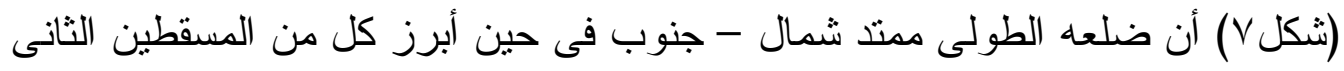

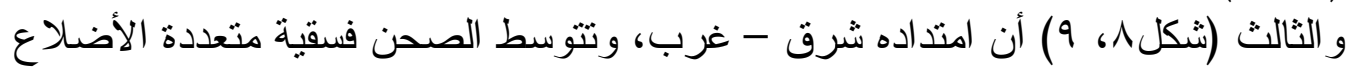

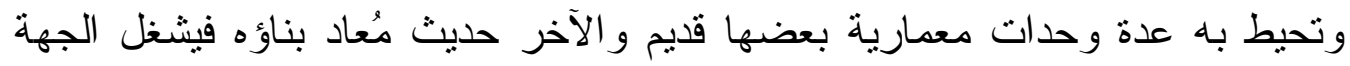

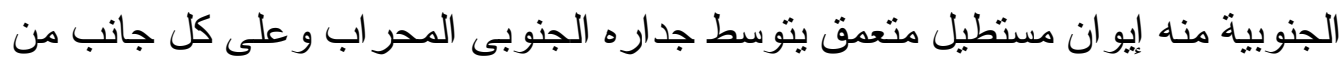

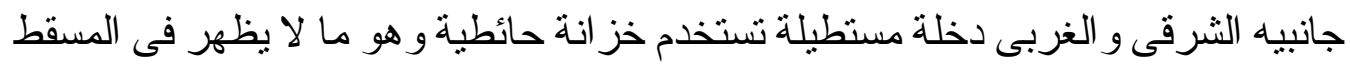

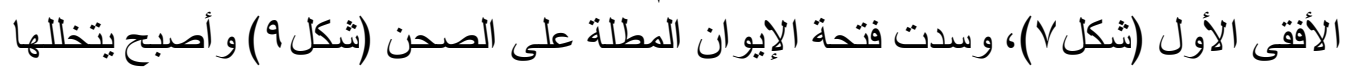

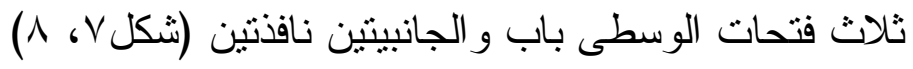


ويشغل الجهة الغربية (لوحة||()) دركاة المدخل وهى بهيئة إيوان مستطيل

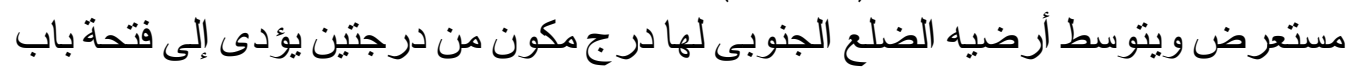

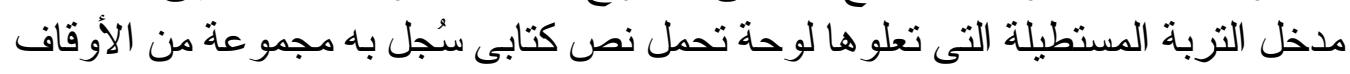

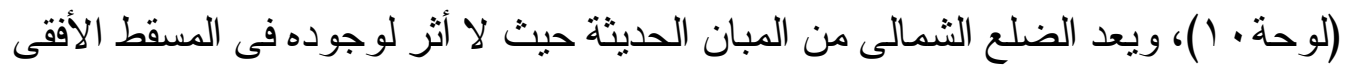

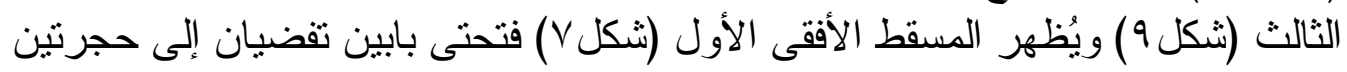

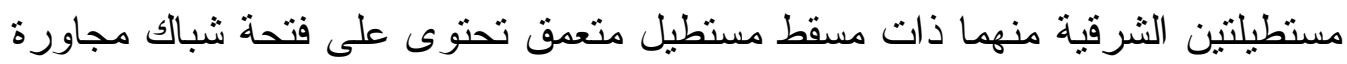

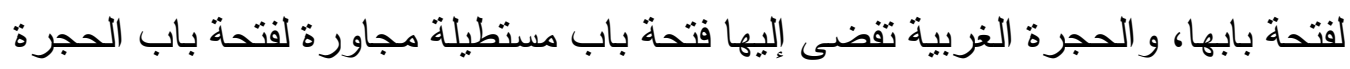

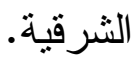

ونرى بالمسقط الأفقى الثانى (شكلى) أن الجدار الثمالى للاركاة تتخلله ثناث فتحات

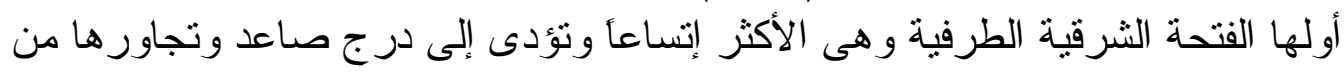
الغرب الفتحتان الاخرتان وهما عبارة عن بابين مستطيلين يفضيان إلى حجرة الى مستطيلة.

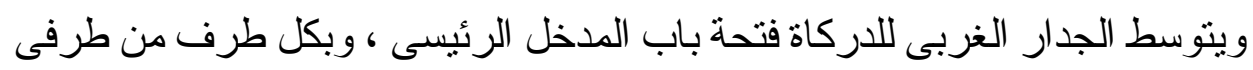

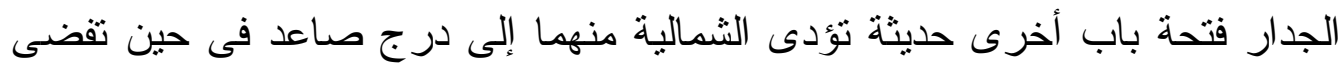

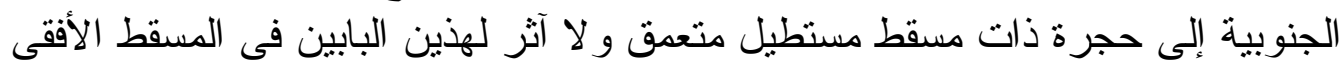

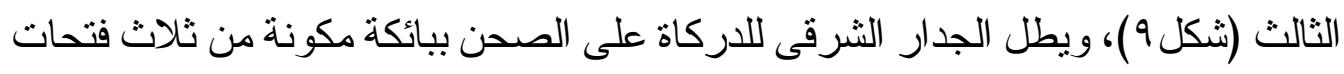

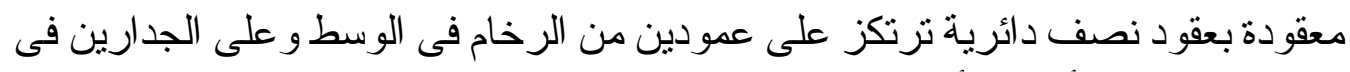

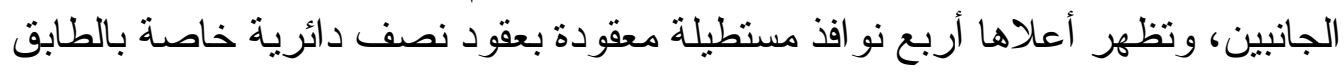

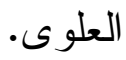

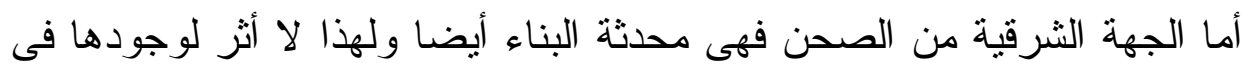

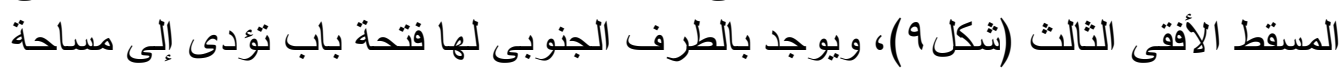

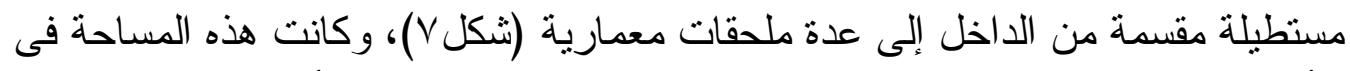

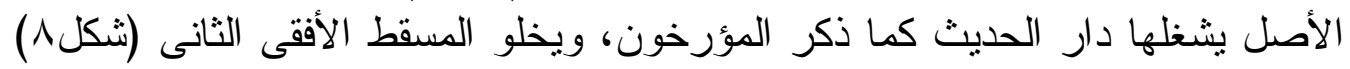

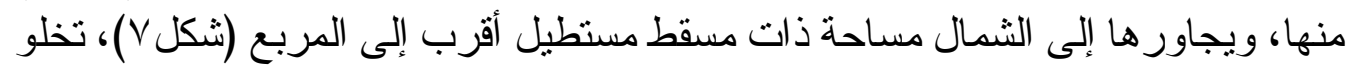

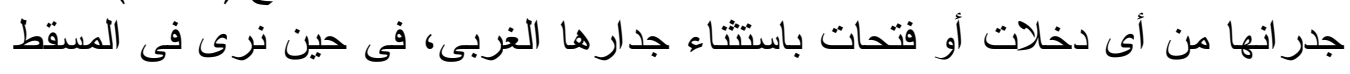

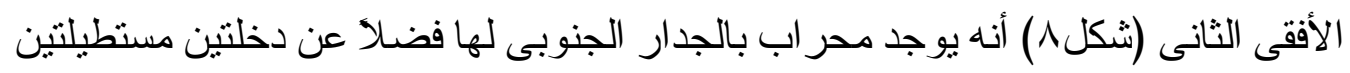

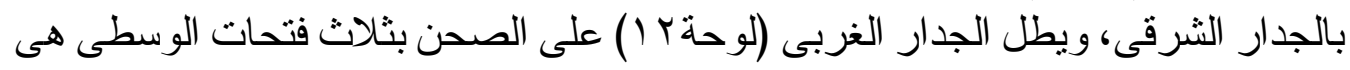

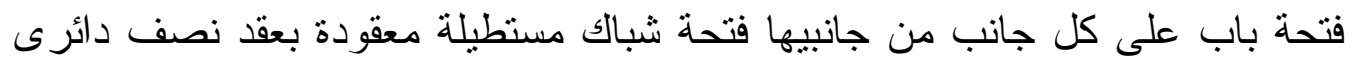


ويعلو ها فى الطابق العلوى ثلاثث نو افذ معقودة بعقود نصف دائرية الوسطى أكثر إتساعاً

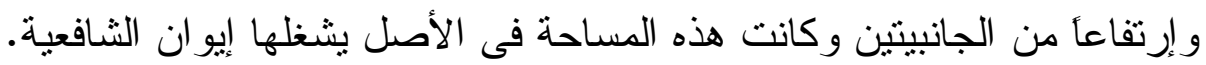

وبالنسبة للجهة الثمالية من الصدن فهى من الأجز اء المعاد بنائها ولذلك لا وجود

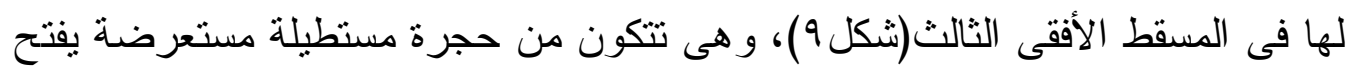

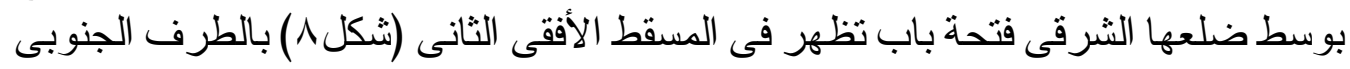

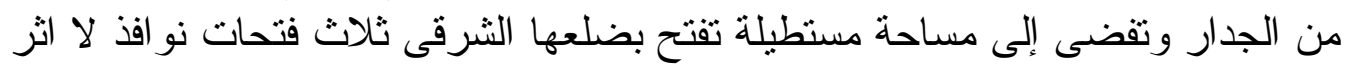

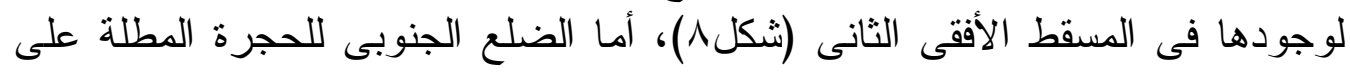

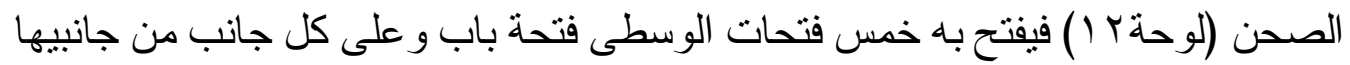

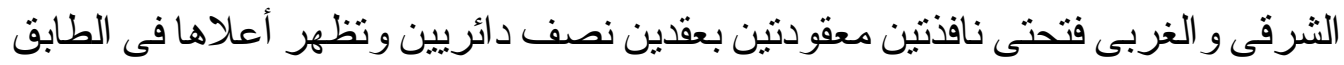

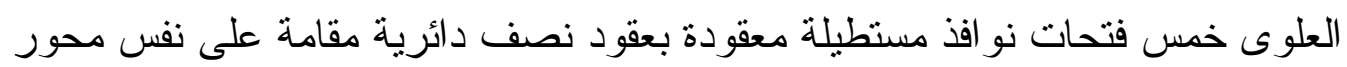

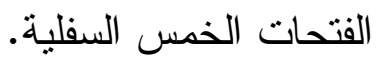

\section{التربية(قبة (لافن):}

تتشغل التربة الركن الجنوبى الغربى من المدرسة ويتم الدخول إليها عن طريق فتحة

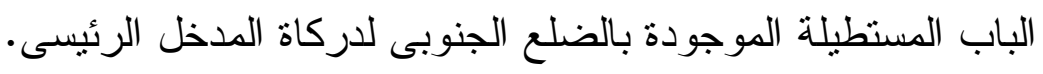

وتتألف من الداخل من مكعب سفلى بكل ضلع من أضلاعه الأربعة دخلة كبيرة

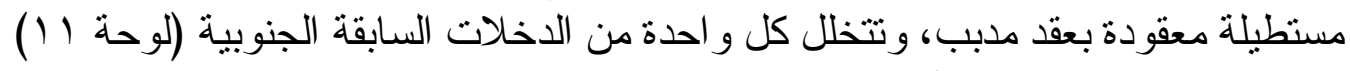

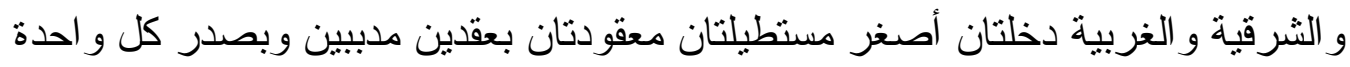

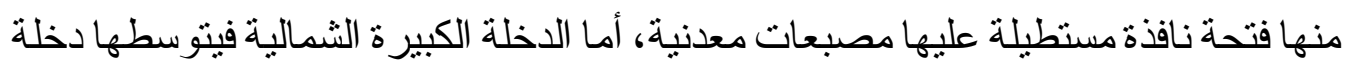

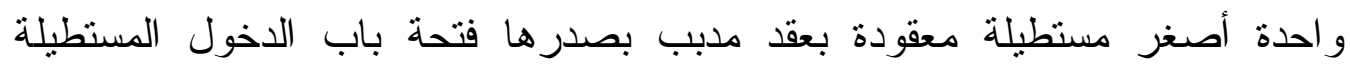
(لوحة ؛ ()، ونلاحظ وجود قمرية مستديرة أسفل عقد كل دخلة معقودة كبيرة.

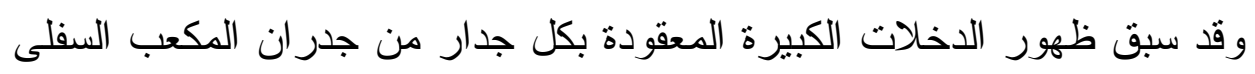

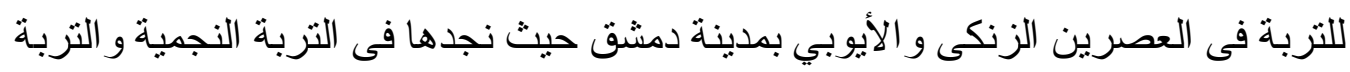

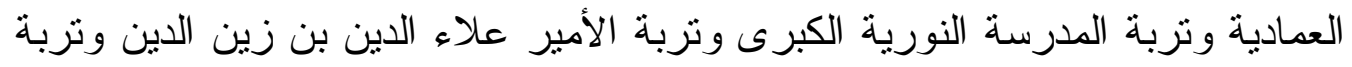

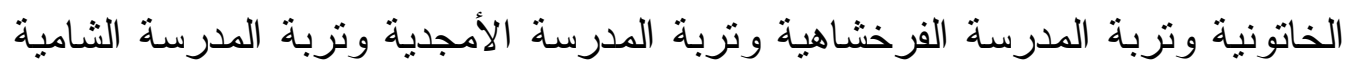

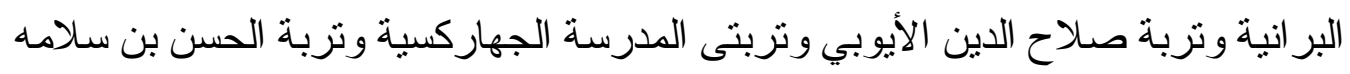


الرقى وتربة المدرسة الماردانية وتربة المدرسة العادلية الكبرى وتربة المدرسة العزية

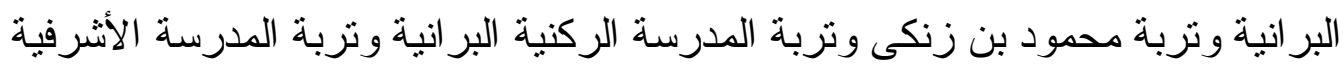
البر انية وتربة ريحان وتربة الحافظية وتربة المدرسة القليجية و التربة القيمرية.

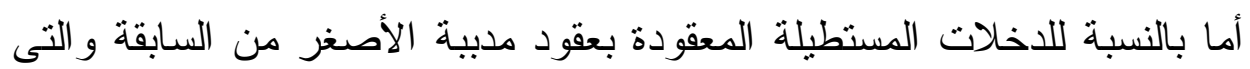

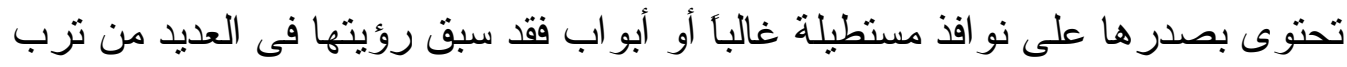

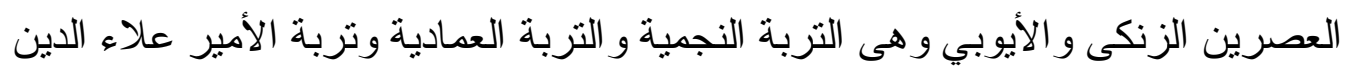

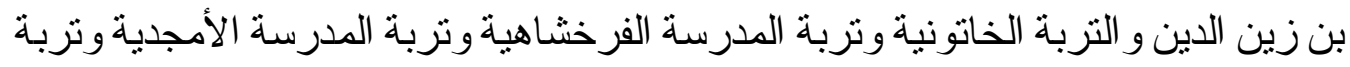

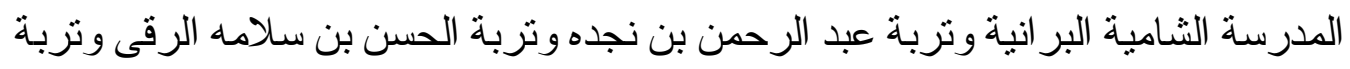

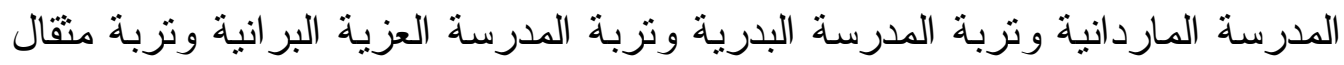

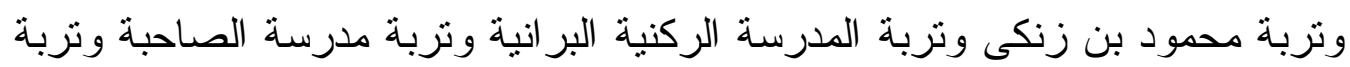

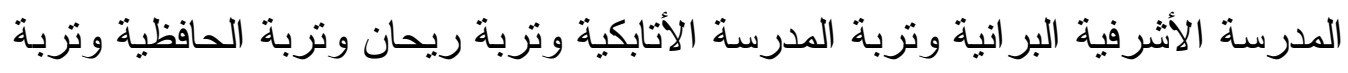
المدرسة المرشدية وتربة المدرسة القليجية وتربة مدرسة العربة العالمة أمة اللطيف و التربة التربة

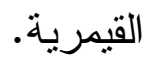

وتحصر الدخلتان الأصغر اللتان بالجدار الجنوبى فى منتصف المسافة بينهما

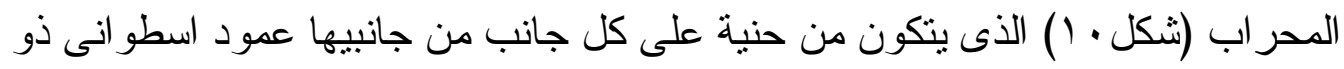

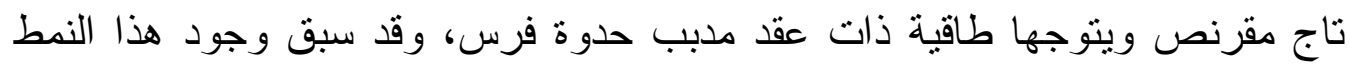

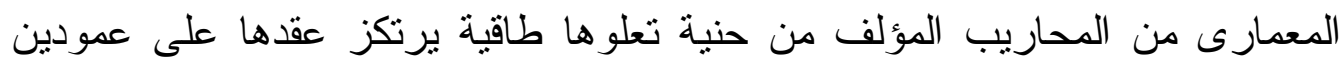

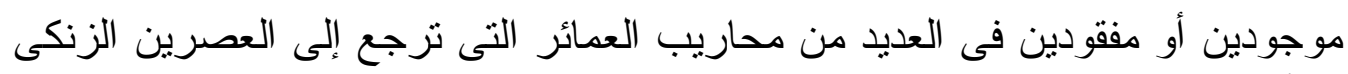

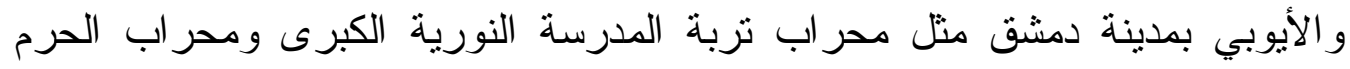

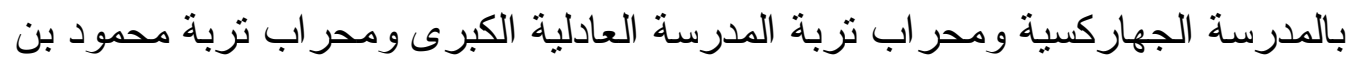
زنكى ومحر اب المدرسة الركنية البرانية ومحر اب جامع التوبة البة ومحراب الكربة المدرسة

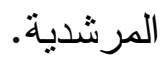

ومن الأمتلة الباقية بمدينة حلب و التى ترجع إلى العصر السلجوقى دحر اب الحرم بمقام

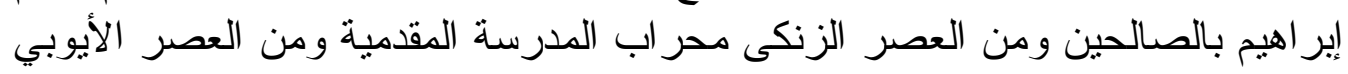

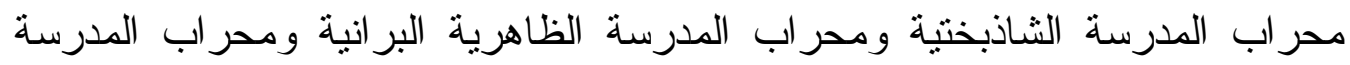
السلطانية ومحر اب المدرسة الكاملية ومحر اب مدرسة الفردوس ومحر البة خابة النقاة 
ومن النماذج الباقية بمدينة القاهرة وتعود إلى العصر الفاطمى محر اب مشهر

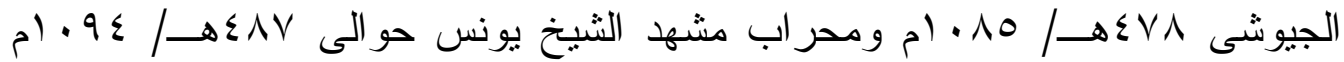

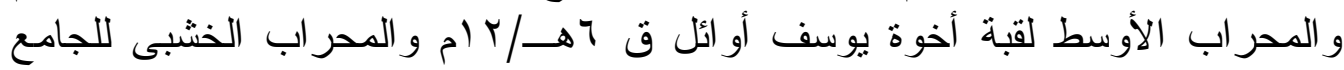

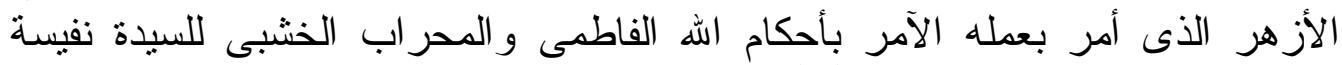
. (

ونشاهد على كل جانب من جانبى عمودى حنية المحر اب الثرقى و الغربى شريط

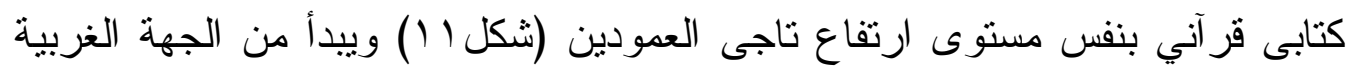

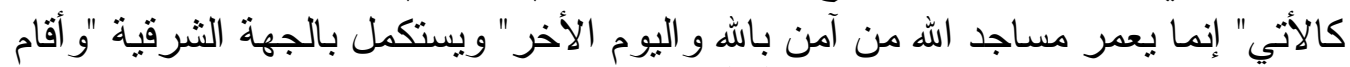

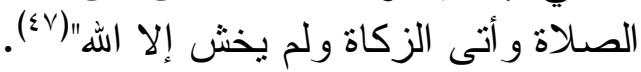

وتوجد بأعلى كل ركن من أركان مكعب التربة إحدى حنايا منطقة الإنتقال

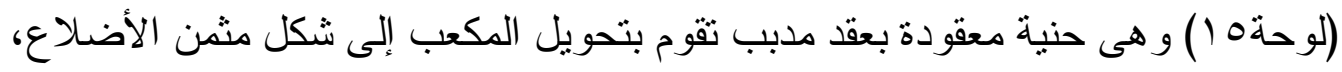

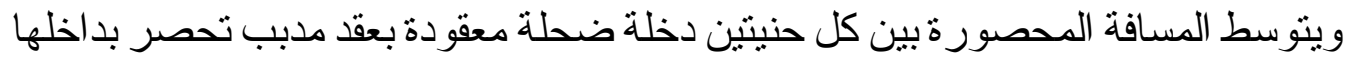
نافذتان مطاولتنان معقودتان تمثل أو اسط منطقة الانتقال.

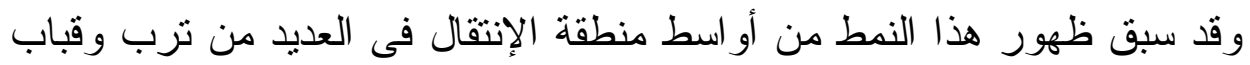

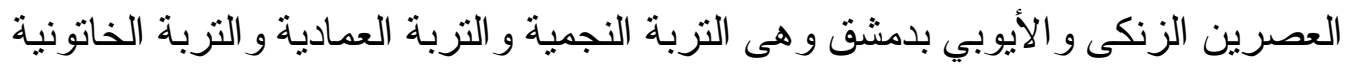

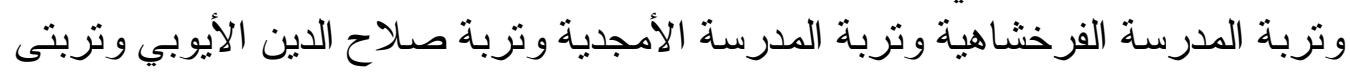

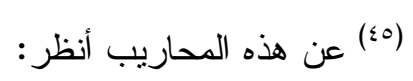

- محمد كامل فارس: محاريب حلب طرز ها الفنية والمعمارية، بحث فى مجلة عاديات حلب البه، الكتابان

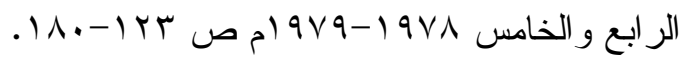

$$
\begin{aligned}
& \text { (1) }
\end{aligned}
$$

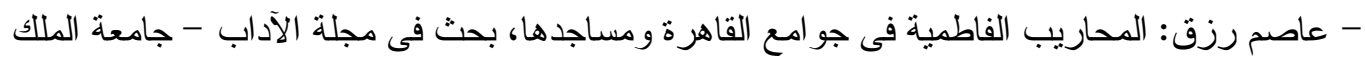

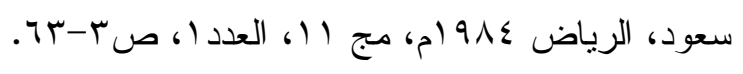

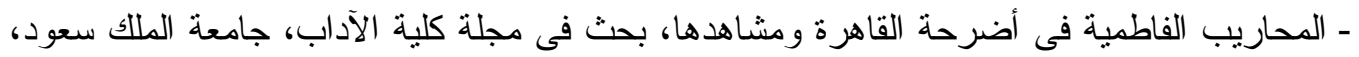

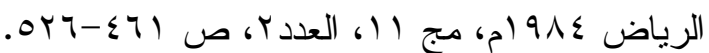

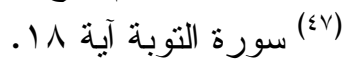




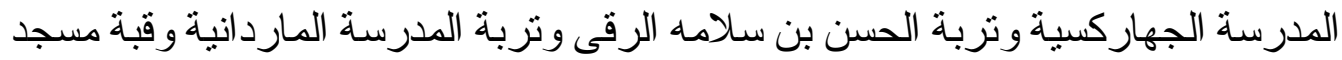

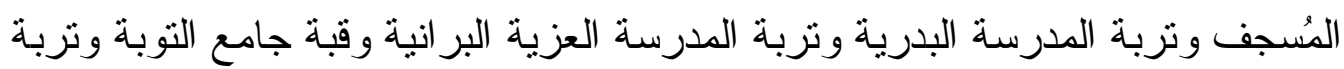

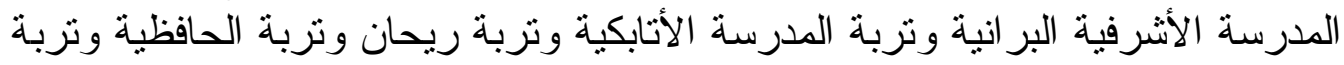

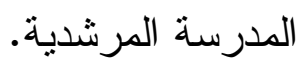

وتأتى أعلى منطقة الانتقال وأواسطها رقبة القبة و التى بطلق عليها المعماريون

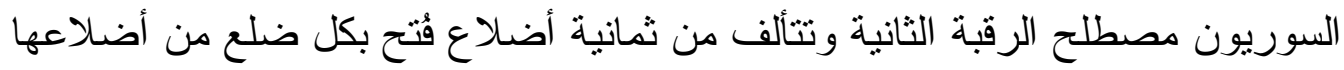

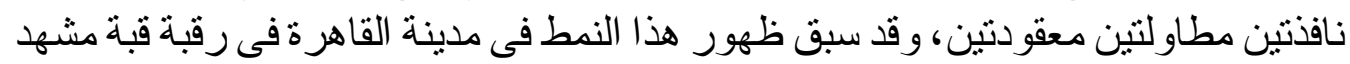

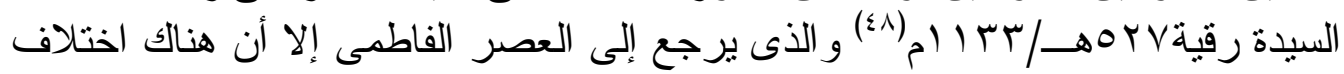

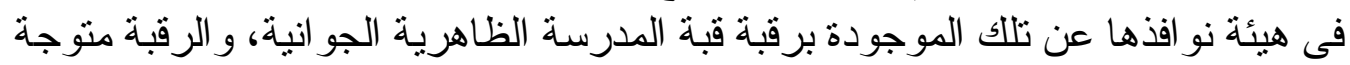
بقبة ملساء.

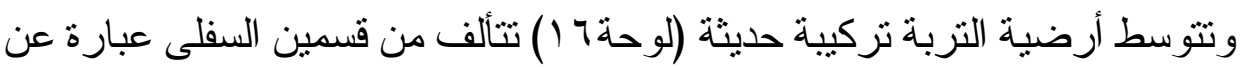

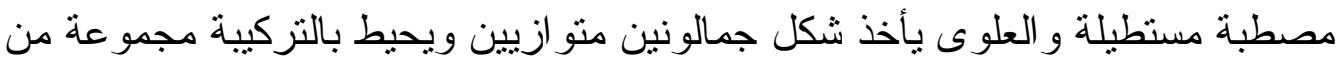

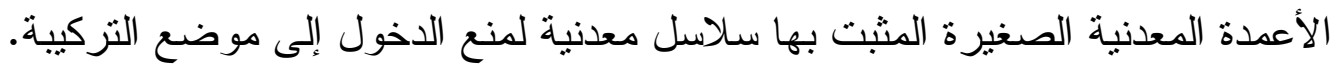

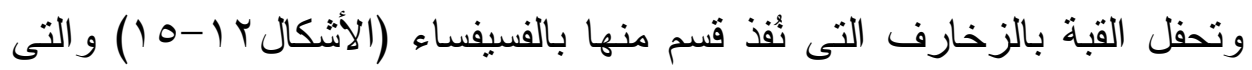

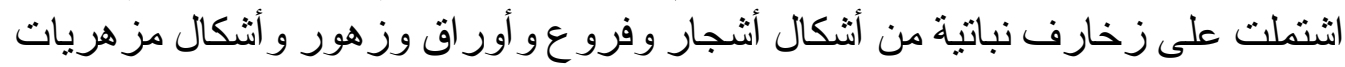

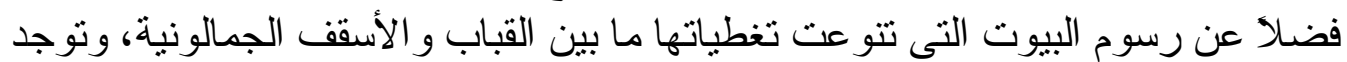

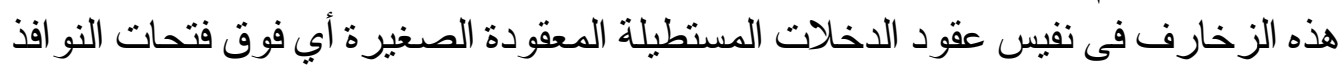

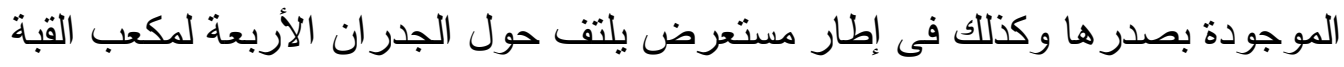
ويبدأ من مستوى القسم العلوى لعقود الدخلات السابقة ويمند إلى أعلى منها بقليل، هذا لألى

$$
\begin{aligned}
& \text { (ఓ人) }
\end{aligned}
$$

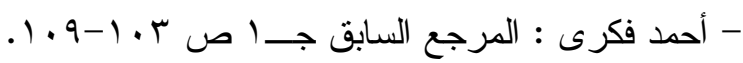

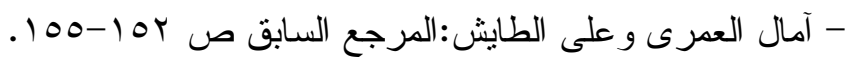

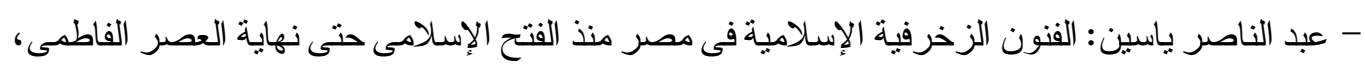

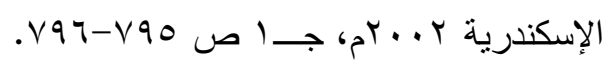

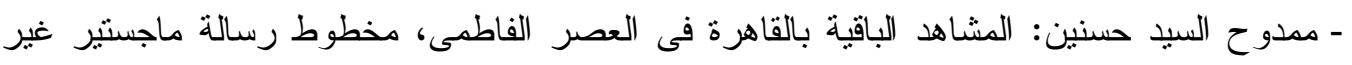

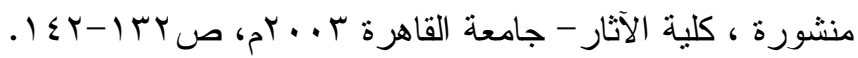


علاوة على زخارف الفسيفساء الموجودة بطاقية المحر اب.

وقد سبق ظهور الفسيفساء فى طو اقى المحاريب بمدينة القاهرة فى العصر الأيوبي

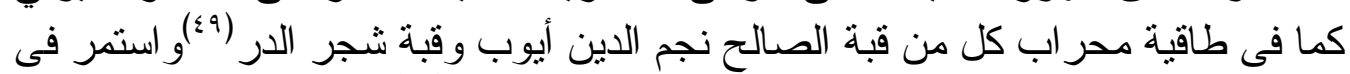

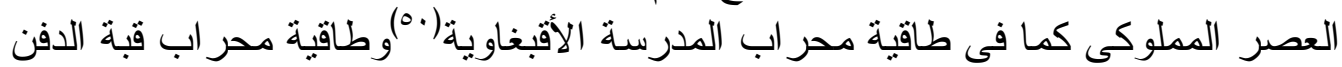

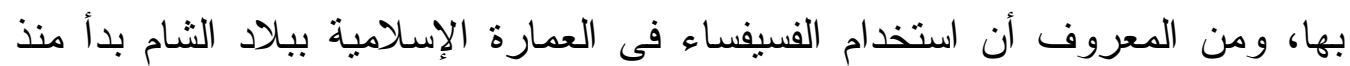

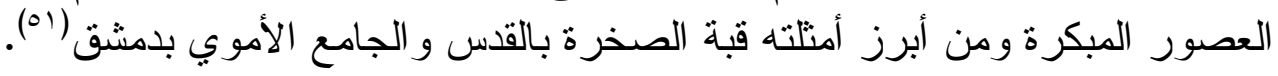

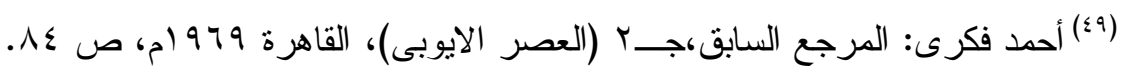

$$
\begin{aligned}
& \text { وعن قبة الصالح نجم الدين أنظر: }
\end{aligned}
$$

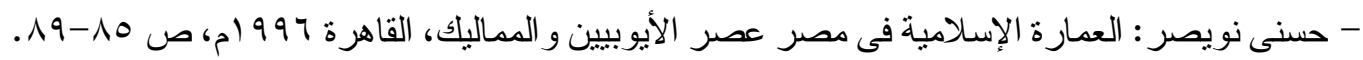

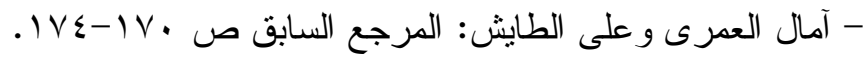

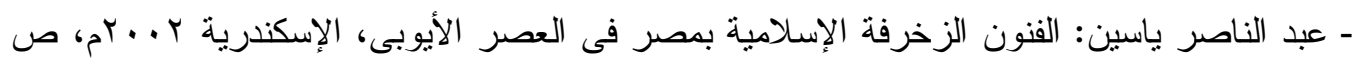

$$
\begin{aligned}
& \text { rTl-ror } \\
& \text { (0) }
\end{aligned}
$$

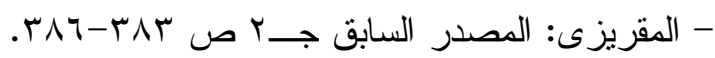

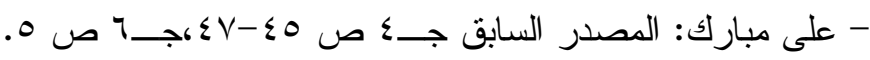

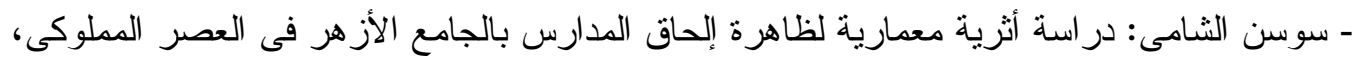

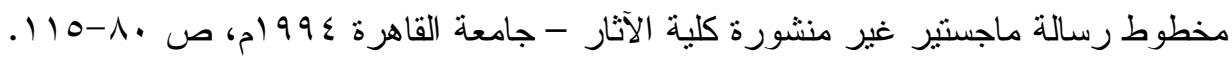

$$
\text { : (1) (1) عن هذه الزخارف }
$$

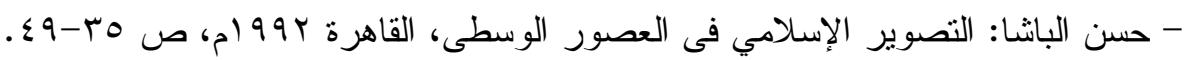

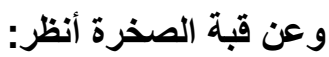

- Rivoire (G.T.), Moslem architecture, its Origins and develapment, London 1918, P.45.

- Richmond (E.Th.), The dome of the rock in Jerusalem a description of its Structure and decoration, Oxford 1924.

- محمد عباس بدر : قبة الصخرة، بحث فى كتاب دراسات فى الآثار الإسلامية، المنظمة العربية للتربية

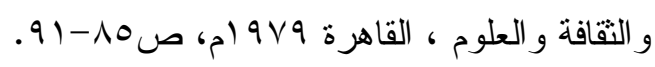

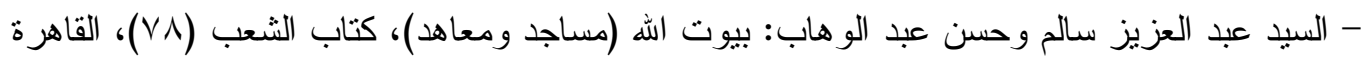

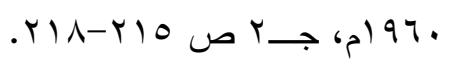


- كريزويل: الآثار الإسلامية الأولى ، نقله إلى العربية عبد الهادى عبله، دمشق ع^9 (م، ص سب-1 آ.

- Grabar (O.) and Nuseibeh (S.), The dome of the Rock, New York, 1996.

- Petrsen (A.), Dictionary of Islamic architecture, London - New York,1996, P.69.

- سوسن سليمان: آثارنا الإسلامية (العمارة فى صدر الإسلام و العصر العباسى الأول)، القاهرة . . . rم، . Vะ-79 ص

- سعاد حسن: در اسات فى العمارة الإسلامية البكرة (در اسة لأهم آثار المدن الإسلامية الأولى وحتى نهاية

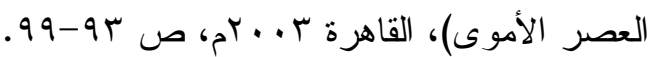

- عبد الله كامل: الأمويون و اثار هم المعمارية (فى الثام و العراق و الحجاز و اليمن ومصر وافريقية)،

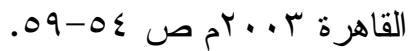

\section{وعن الجامع الأموى أنظر:}

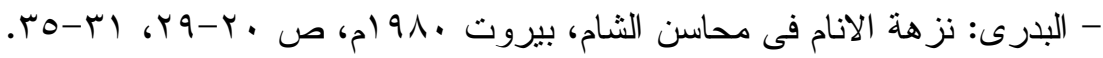

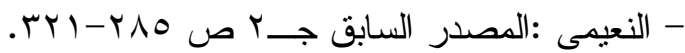

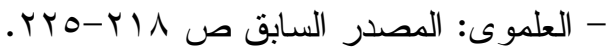
- عبد الرحمن سامى: المصدر السابق ص 9 9 -9V.

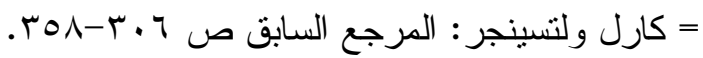

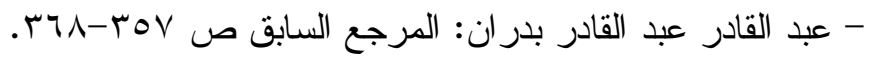

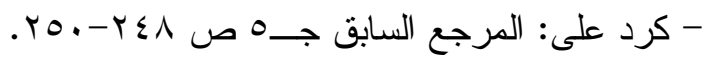

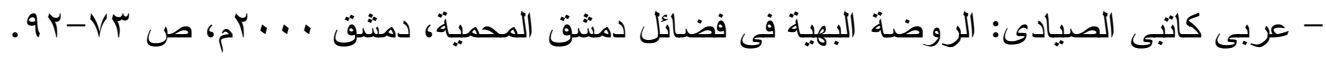

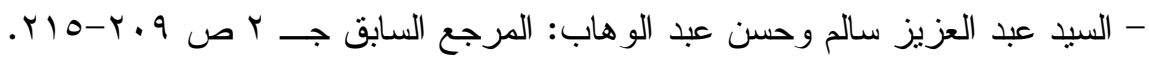

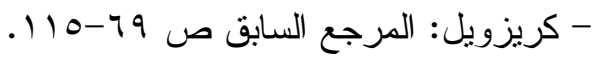

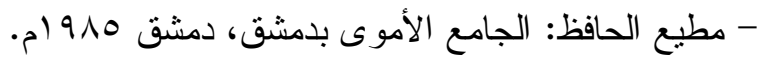
- عبد الباقى إبر اهيم وحازم محمد إبراهيم: المنظور التاريخى للعمارة فى المشرق العربى، مركز

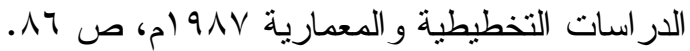

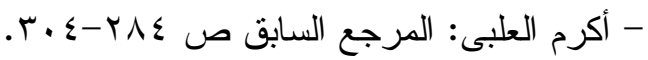

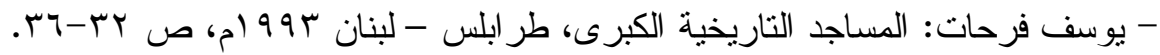
- عبد القادر الريحاوى:جامع دمشق الاموى (التاريخ و التراث و الفن المعمارى)، دمشق 999 ام. م.

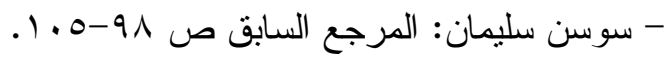
- سعاد حسن: المرجع السابق ص • • V-V. 
وُُْفذ القسم الآخر من زخارف التربة بالرخام وهو بشغخل القسم السفلى من الجدران

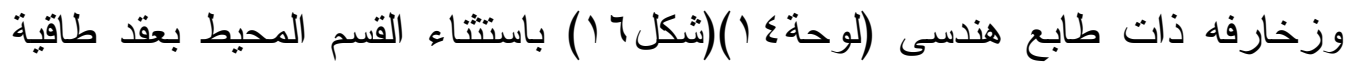

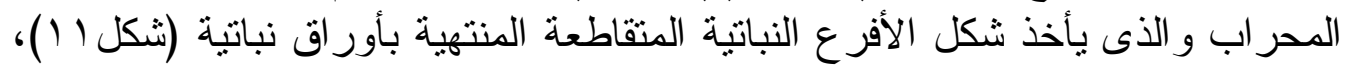

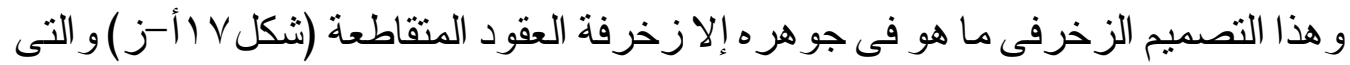

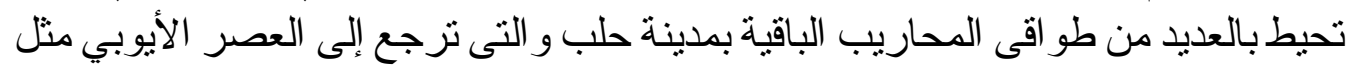

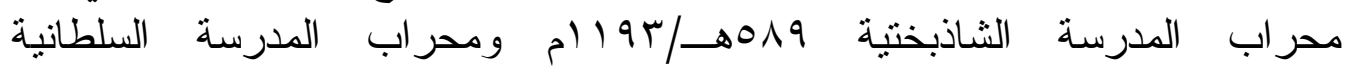

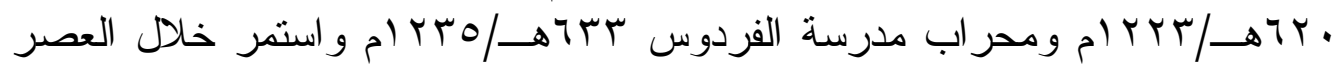

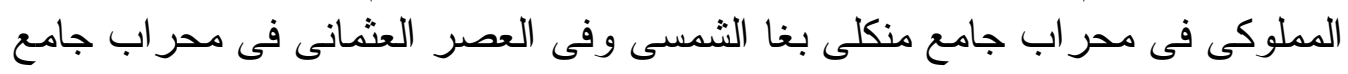

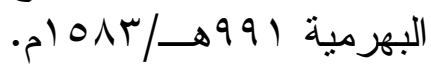

ومن أمتلة محاريب العمائر الدينية الباقية بمدينة دمشق و التىى تعود إلى العصر

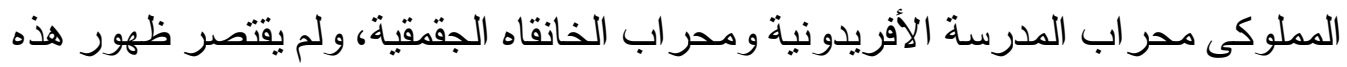

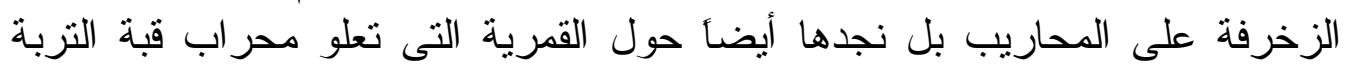

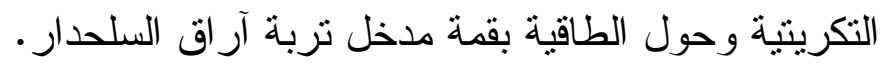

ومن نماذجها الباقية بفلسطين وترجع إلى العصر المملوكى محر اب قبة السلسلة

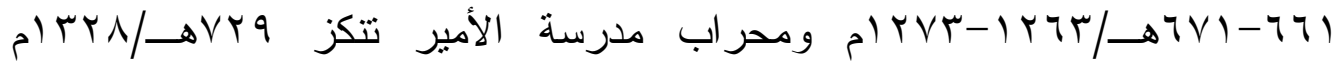

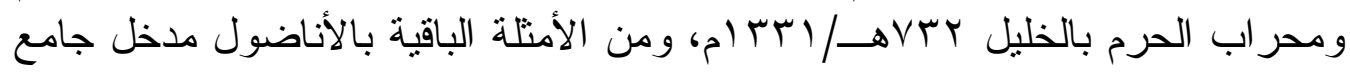

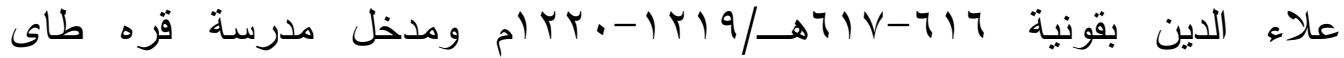

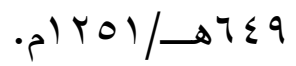

وظهر هذا التقليد الزخرفى بمصر منذ العصر الفاطمى ومن أمتلته الباقية الزخرفة

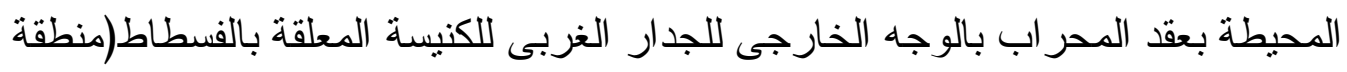

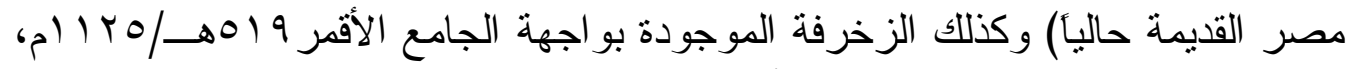

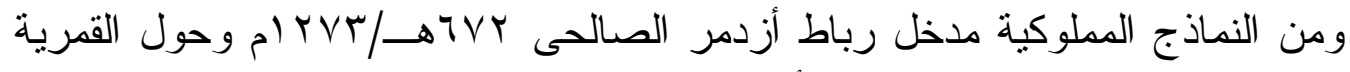

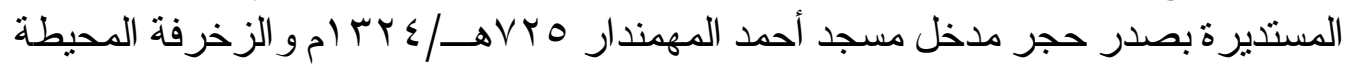
بالقمريات المستديرة و المطولة بالو اجهات الخارجية لقبة الدفن بمدرسة السلطان حسن العنان .

- عبد اله كامل: المرجع السابق ص r r-V9. 
وقد سبق ظهور هذه الزخرفة بالمغرب الإسلامي فنجدها بإحدى البو ابات بجامع

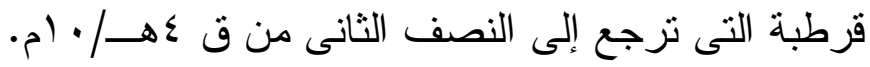

\section{الواجهات الخارجية (لوحة V ):}

تعد الو اجهة الغربية هى الرئيسية ويشغل القسم الجنوبى منها واجهة التربة وبها من

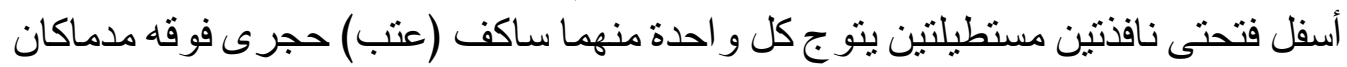

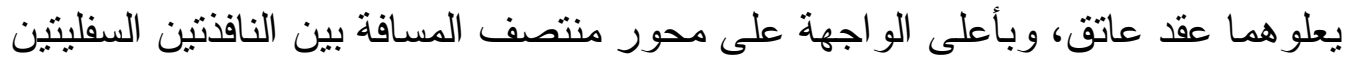

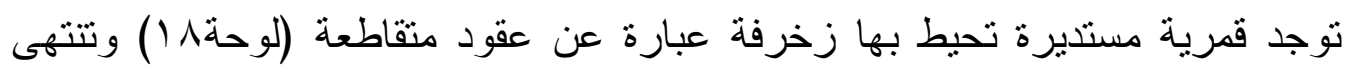

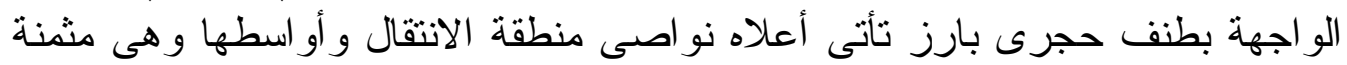

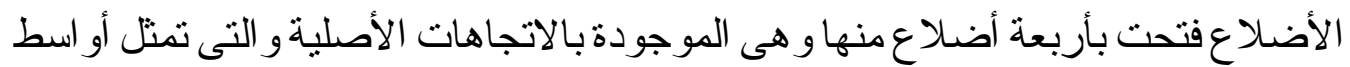

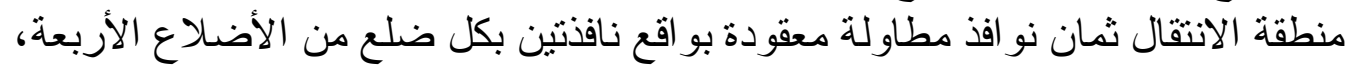

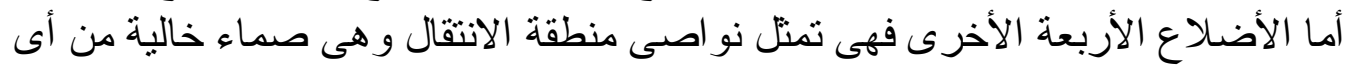

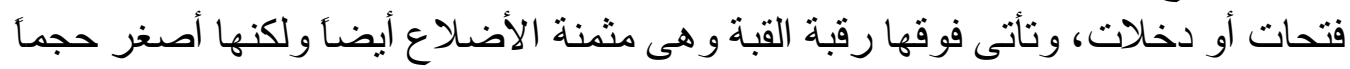

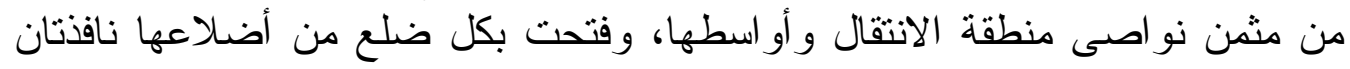

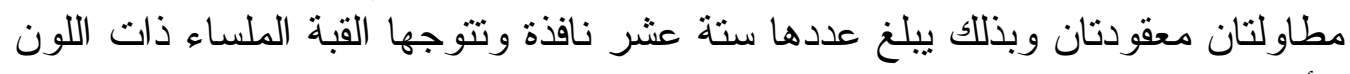

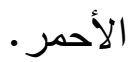

ويجاور و اجهة القبة من ناحية الثمال المدخل الرئيسى (لوحة 1 (1) وهو عبارة عن

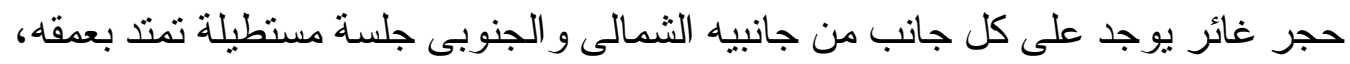

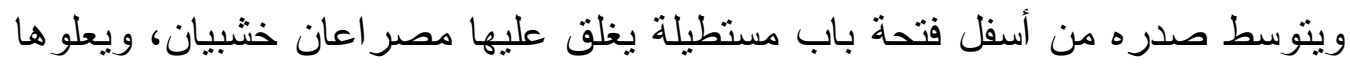

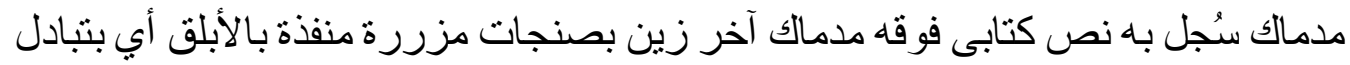

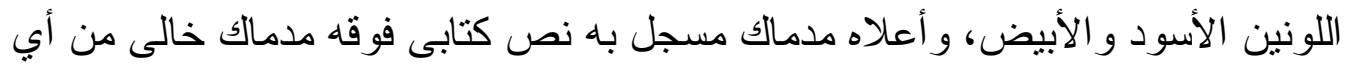

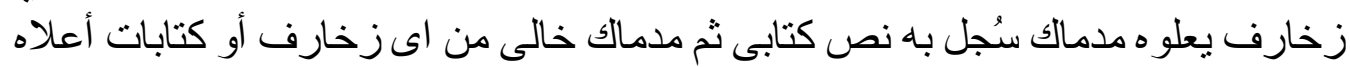

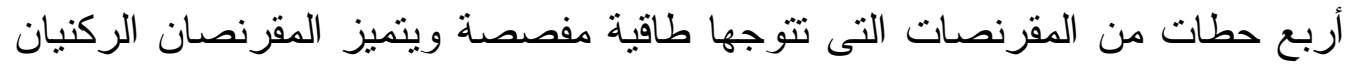

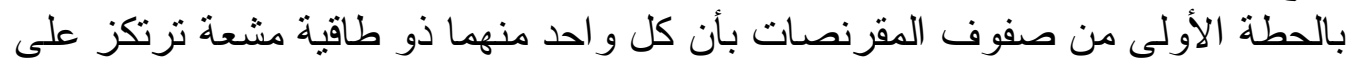

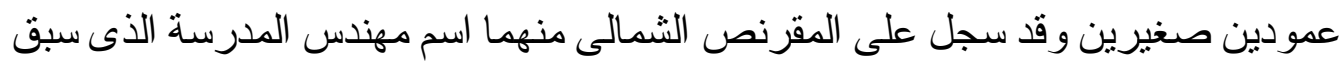

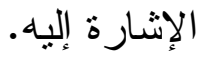


دراسات في آثار الوطن العربي ؛

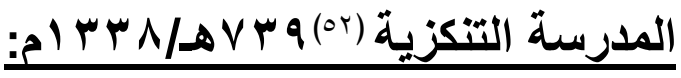

الموقع:

تقع شرقى حمام نور الدين، وتجاه دار الذهب، وكان فى موضعها قبل بنائها حمام سويد

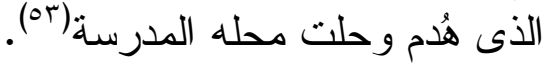

\section{المنشئ وتاريخ الإششاء والمشرف على البناء:}

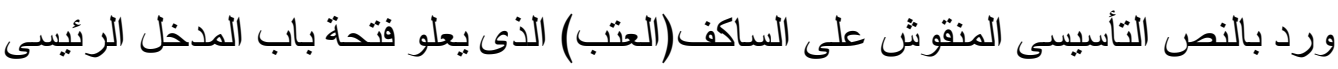

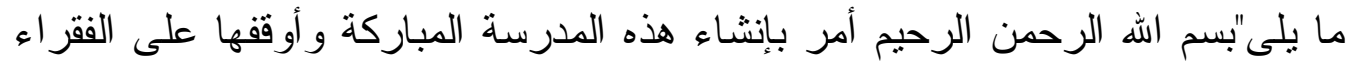

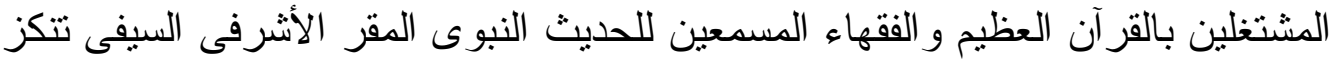

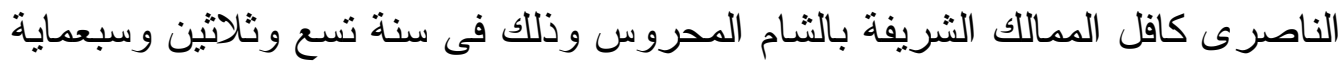
بمبانشرة العبد الفقبر أيدمر المعينى".

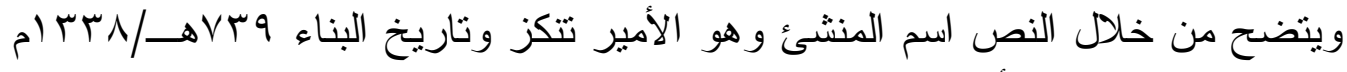
و المشرف على البناء أيدمر المعينى.

\section{ترجمة المنشئ:}

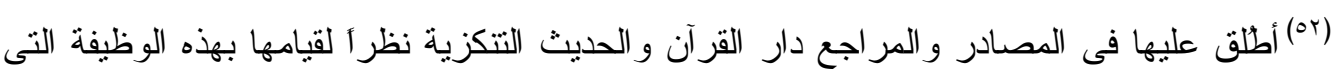

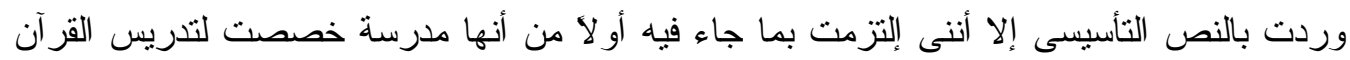

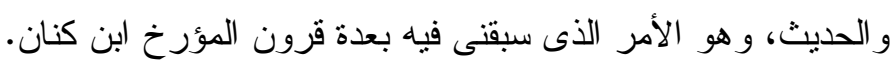

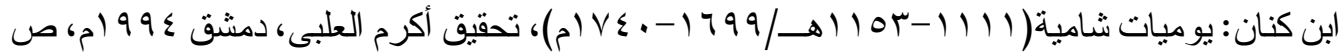
. $\mathrm{\wedge} \wedge$

- (بr)

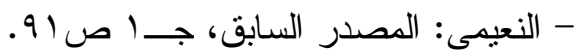

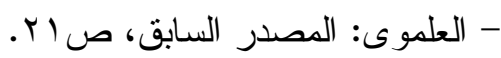

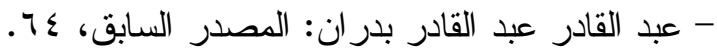

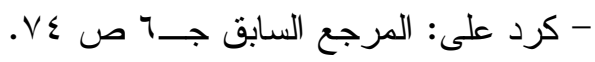

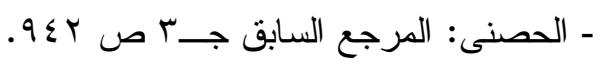


الأمير الكبير المعظم المهيب سيف الدين أبو سعيد تتكز (\&)(الحسامى الناصرى نائب

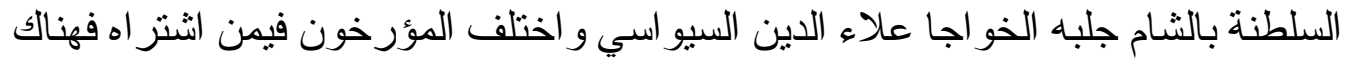

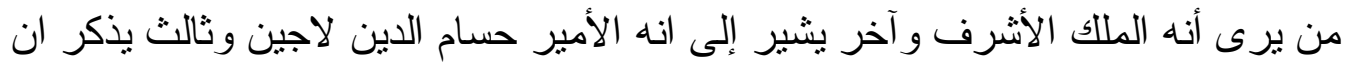

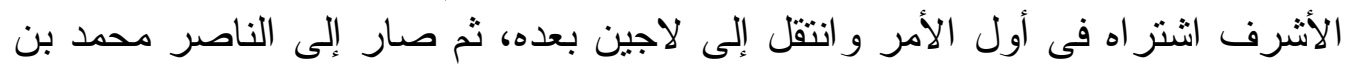

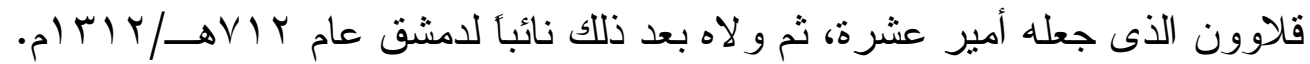

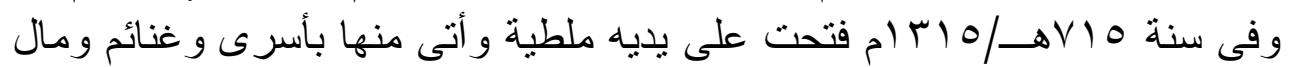

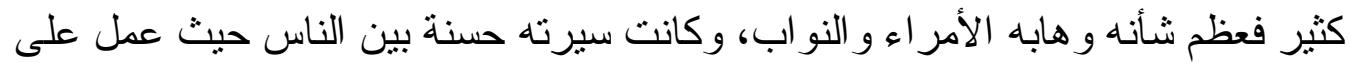

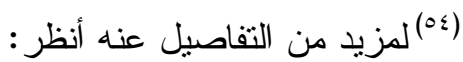

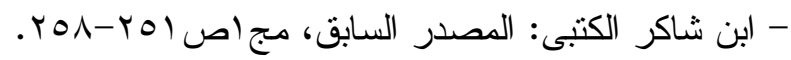

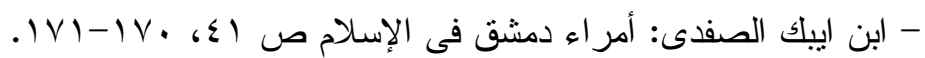

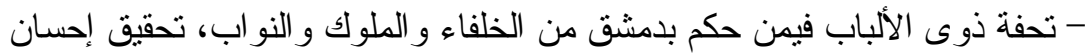

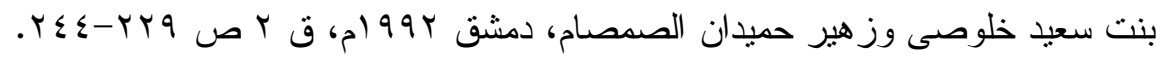

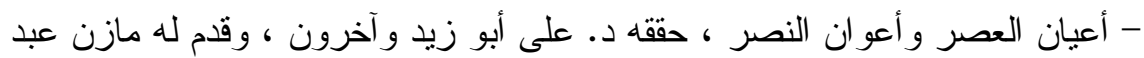

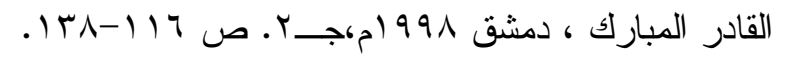

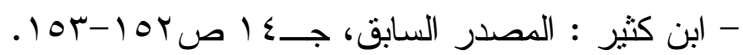

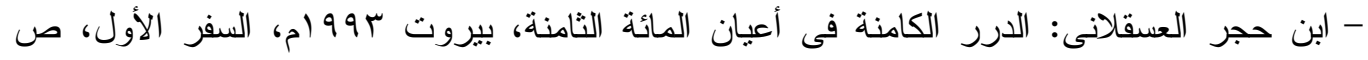
orv-or.

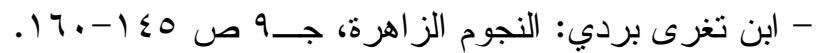

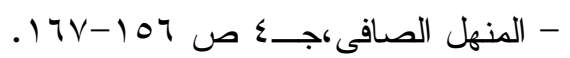

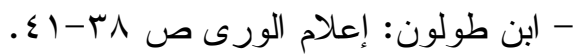
- الثوكانى: البدر الطالع بمحاسن من بعد القرن السابع ، حققه وقدم له د. د. حسين بن عبد الله العمرى ،

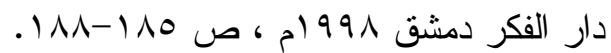

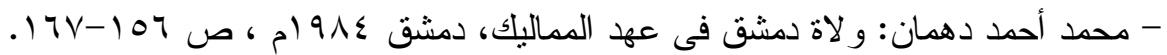

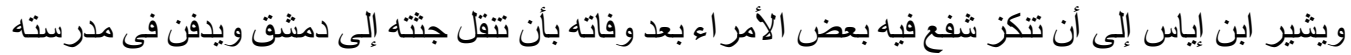

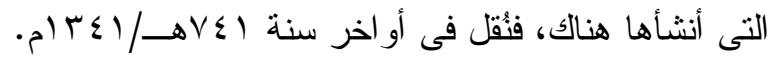

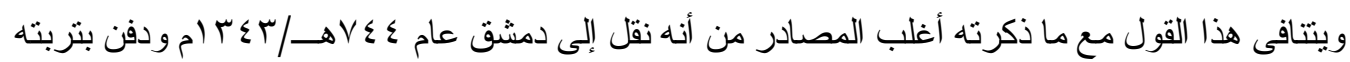
هناك بجو ار جامعه.

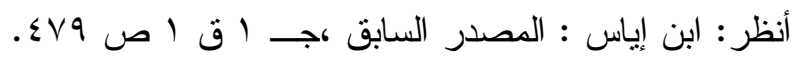


تأمين الطرق ورخصت الأسعار فى عهده ونشر العدل بين الناس حيث لم يكن أحد فى ألى إنى

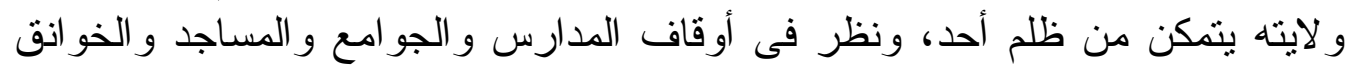

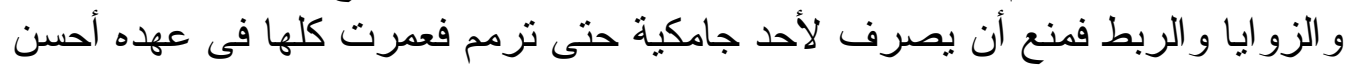

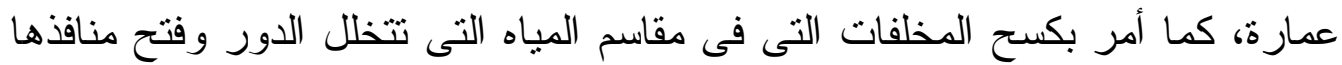

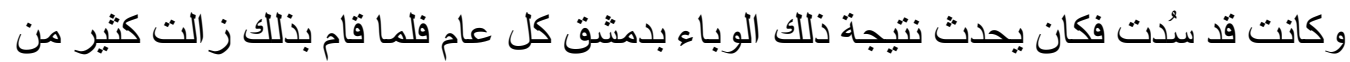

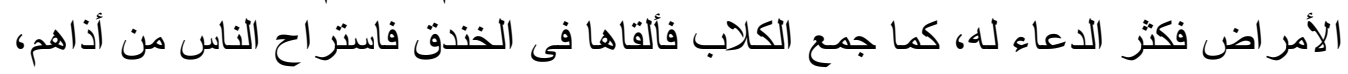

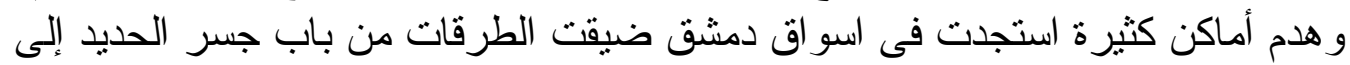

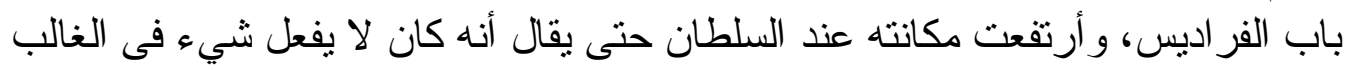

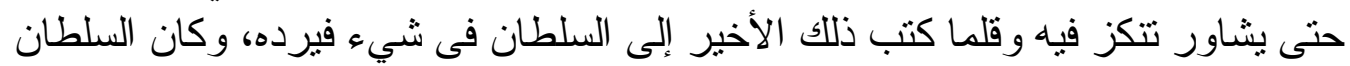

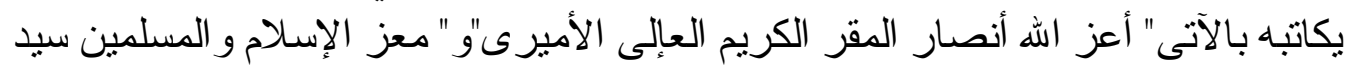

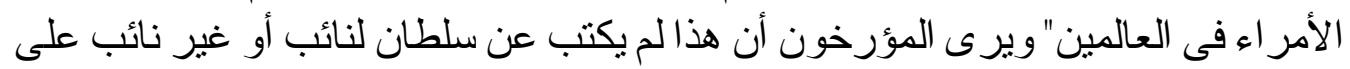

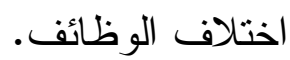

ويروى أن السلطان الناصر محمد قد تغير على تتكز بسبب ان الناصر أر اد ان يجهز إنيز

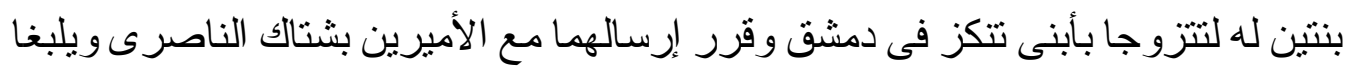

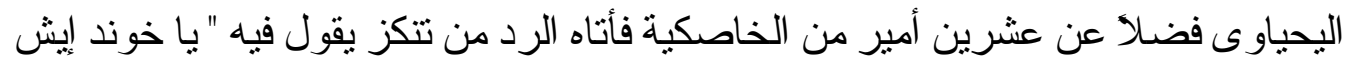

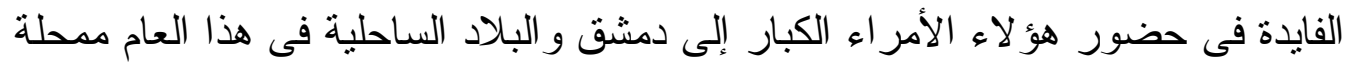

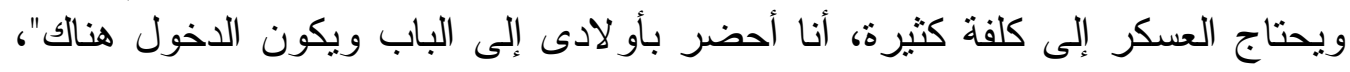

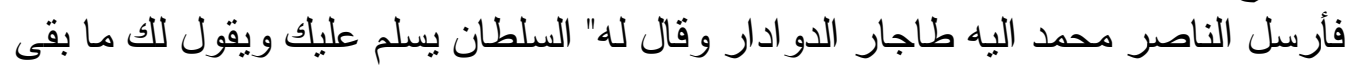

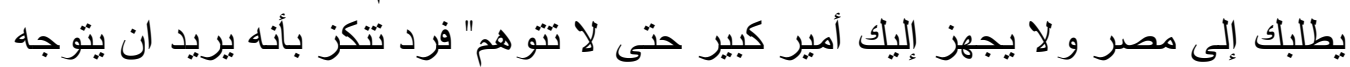

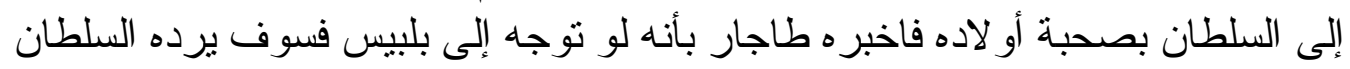

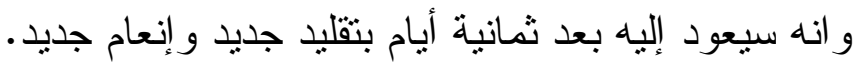

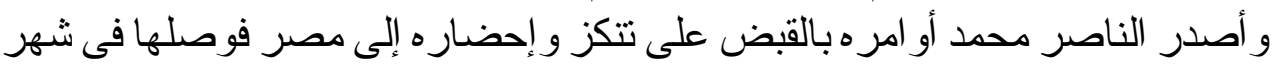

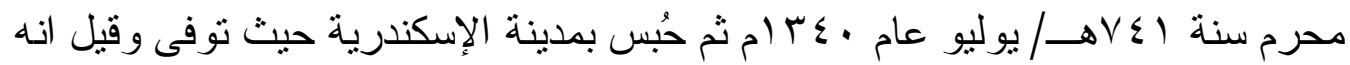

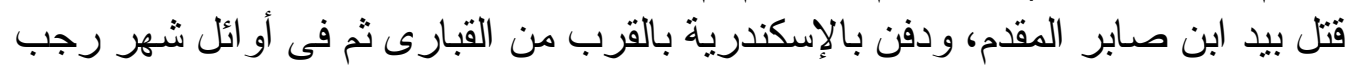

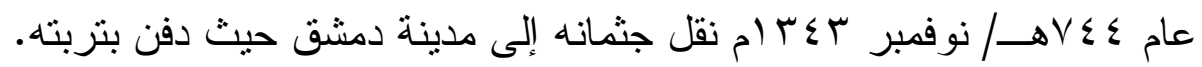

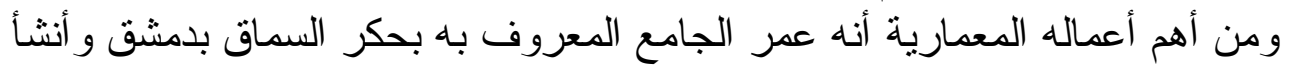

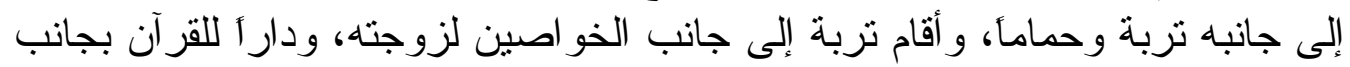

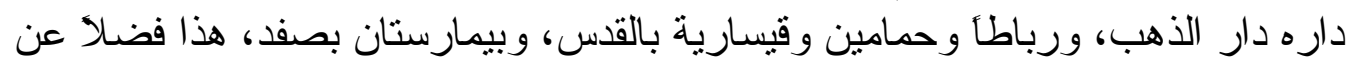

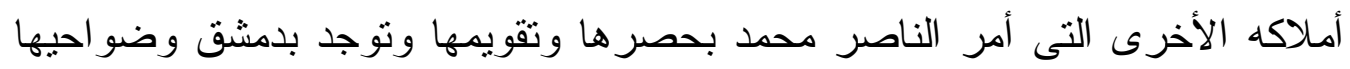




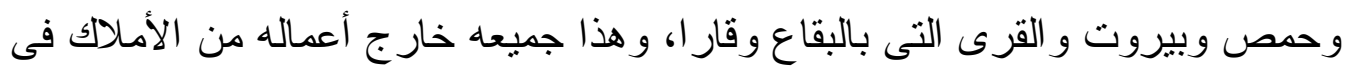

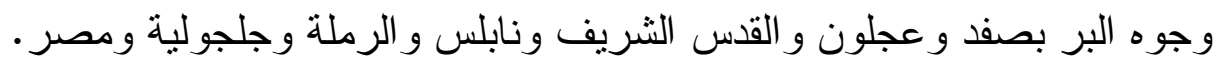
أوقاف المدرسة:

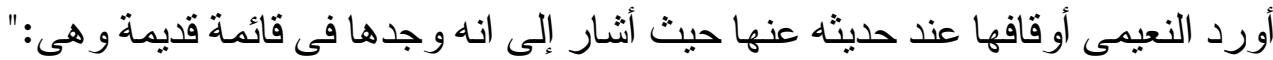

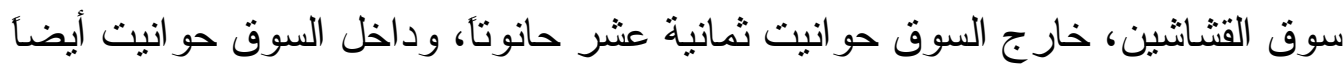

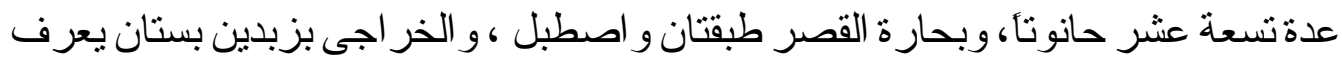

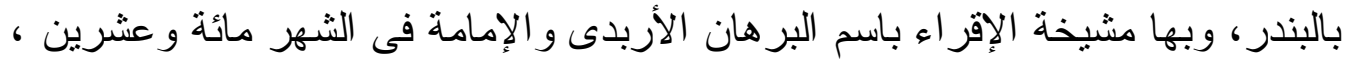

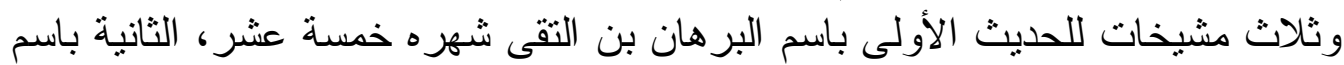

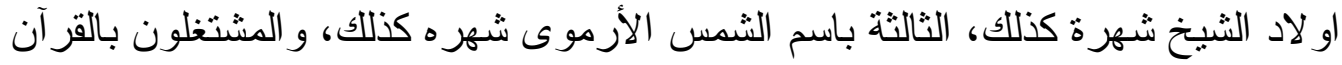

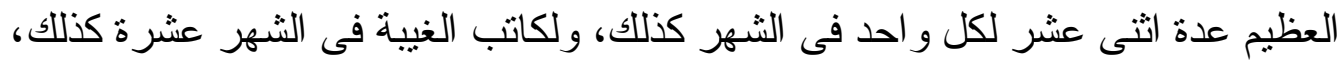

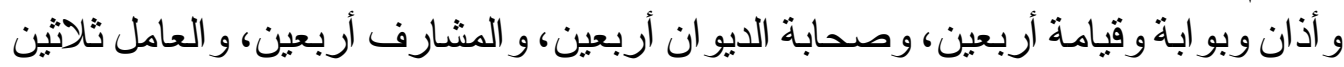

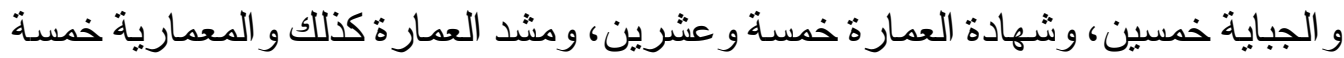

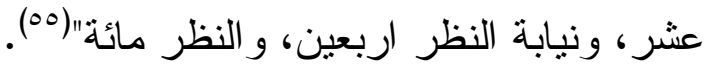

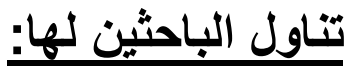

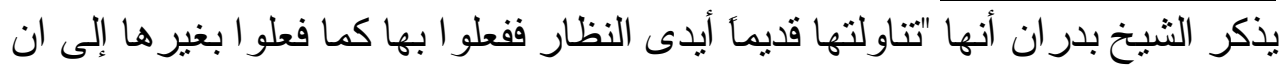

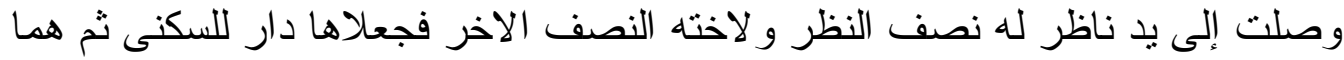

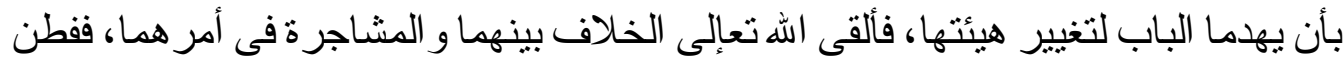

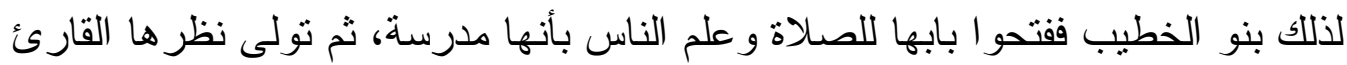

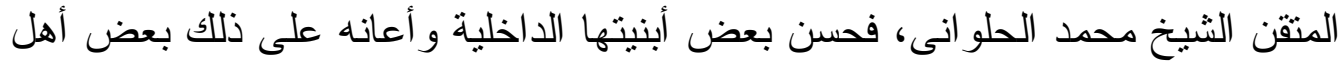

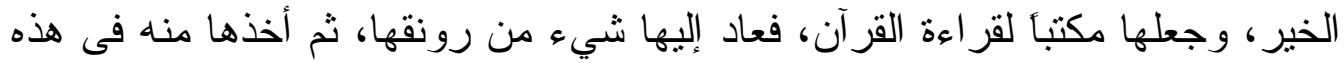

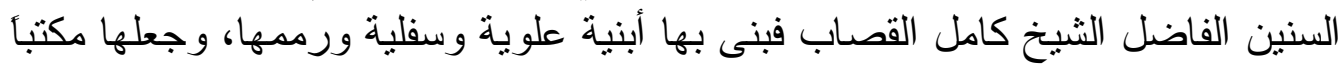

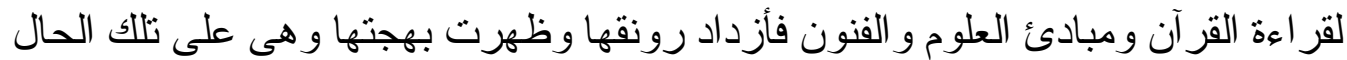

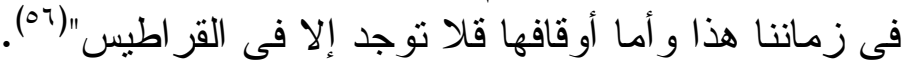

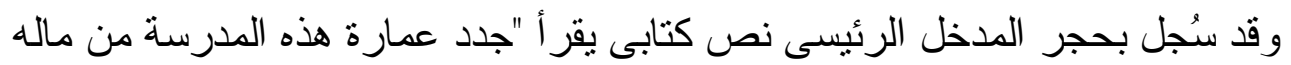

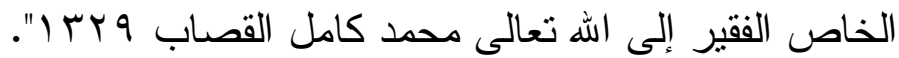

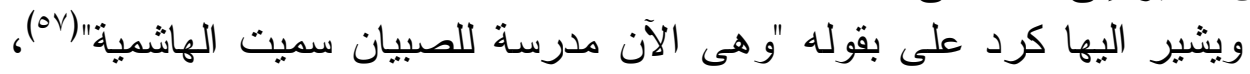

$$
\begin{aligned}
& \text { (00) النعيمى: المصدر السابق جـ اص ع } 9 .
\end{aligned}
$$

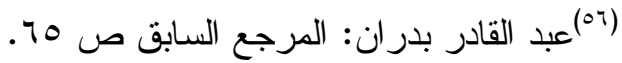

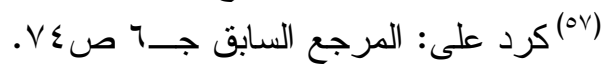


ويصفها اسعد طلس بأنها "مدرسة عامرة لها جبهة حجرية ضخمة وباب ذو زخارف و هى

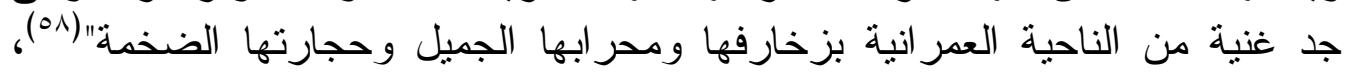
ويضيف الريحاوى أن أهم ما بقى منها واجهتها الحجرية و الباب ذنى المقرنصات وفريات

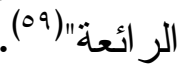

\section{الوصف المعمارى (شكله 1 1):}

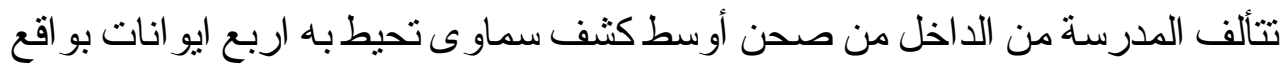

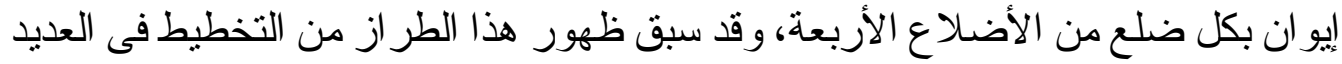

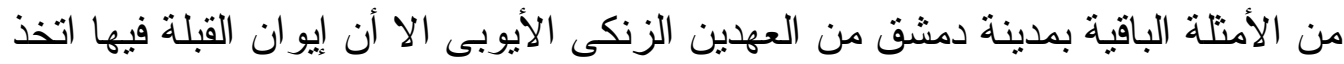

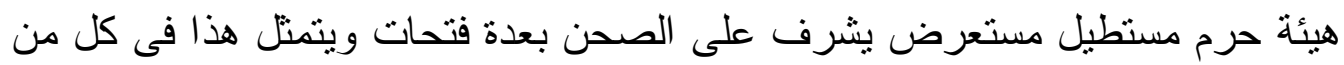

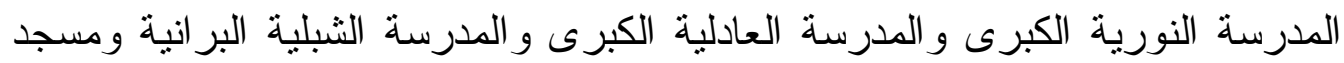

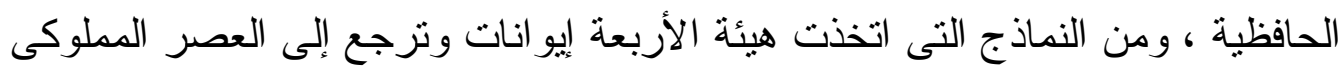
المدرسة الأفريدونية.

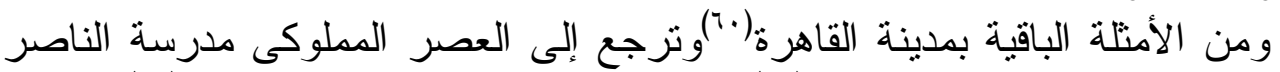

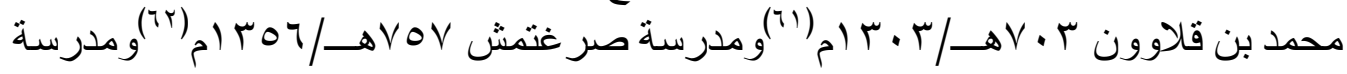

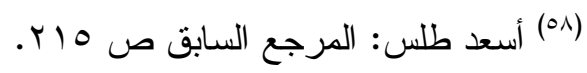

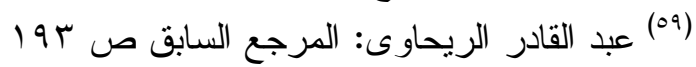
(7.)

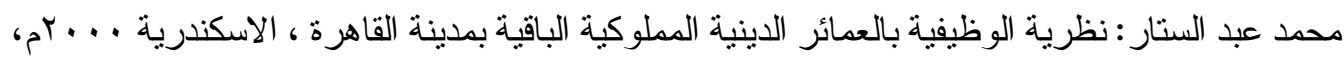

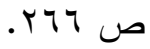

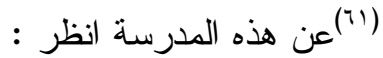

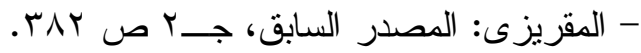

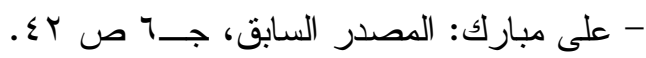

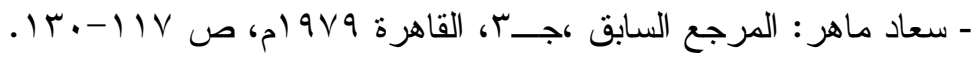

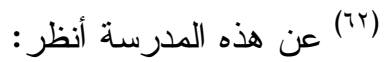

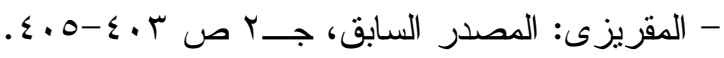

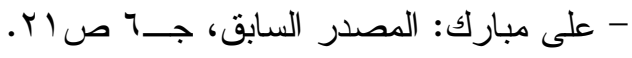

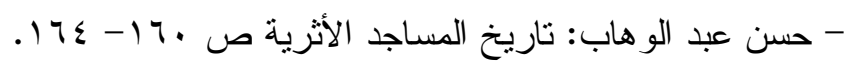

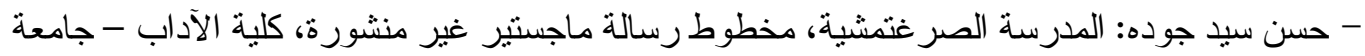

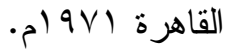




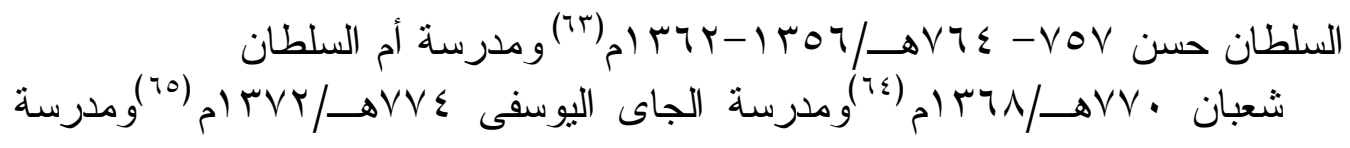

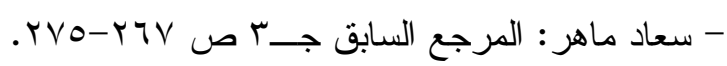
- ياسر يحيى: التحليل الإنثائي للمبانى الحجرية التاريخية الإسلامية (النماذج الرقمية للحاسب الآلى تطبيقاً

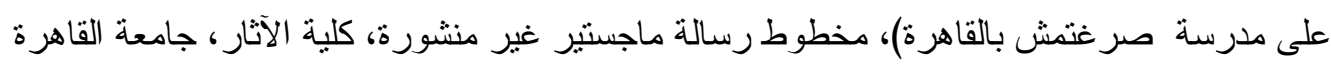

:

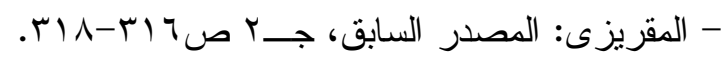

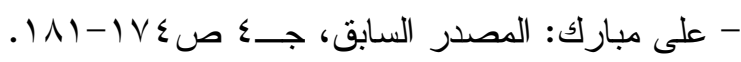

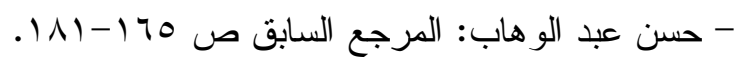

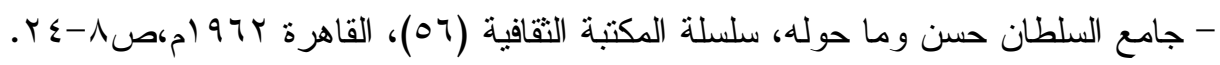
- عبد الرحمن زكىى: بناة القاهرة فى ألف عام، سلسلة المكتبة الثقافية (•r. .OV-Or

- على حسن زغلول: مدرسة السلطان حسن، مخطوط رسالة ماجسنير غير منشورة، كلية الآثار - =

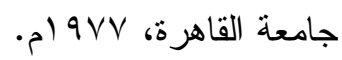

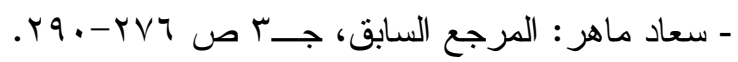

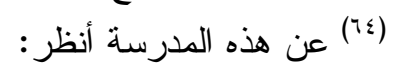

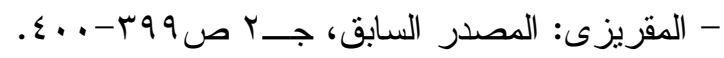

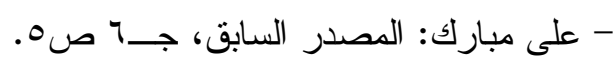

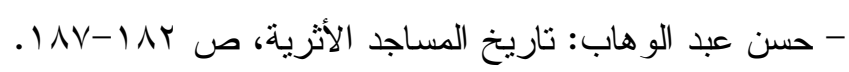

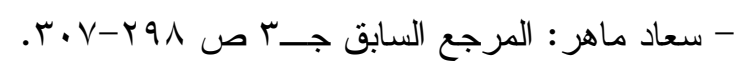

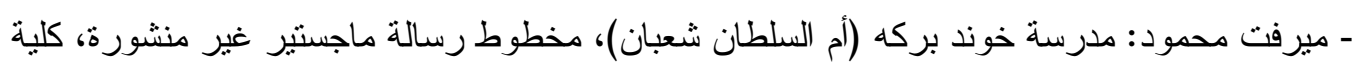

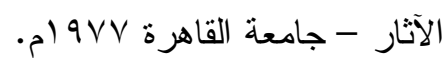
:

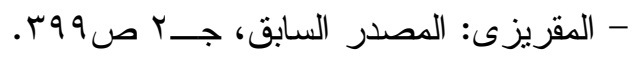

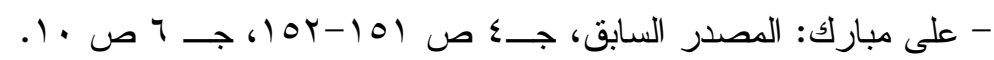

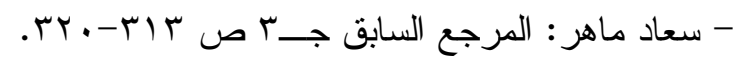

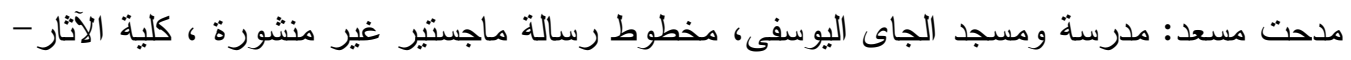

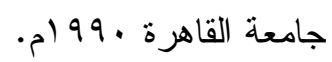




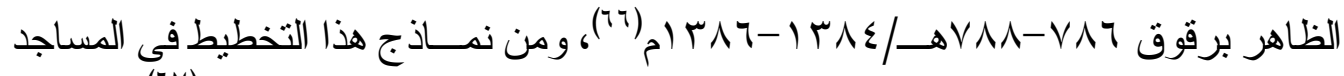

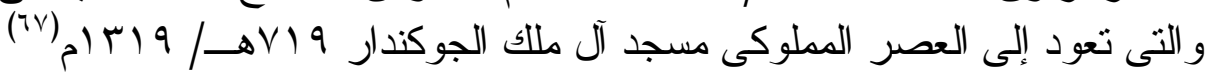

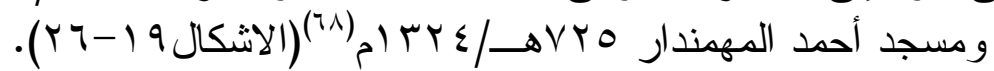

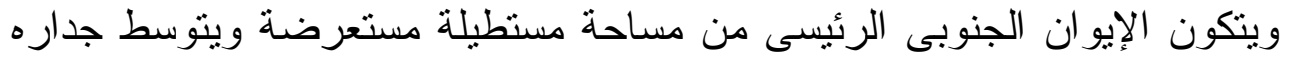

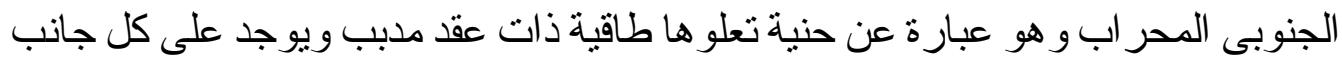

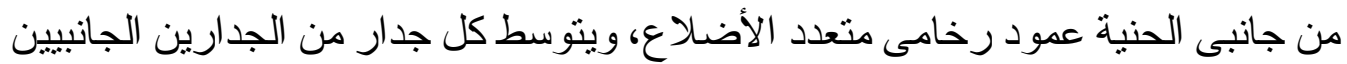

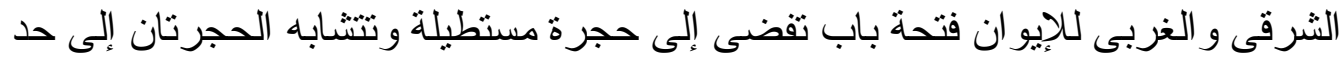
كبير وتوجد بكل من الجدار الشرقى للحجرة الثرقية و الجدار الغربى للحجرة الغربية خز انة حائطية تقابل فتحة باب الدخول إلى الحجرة، ويفتح الإيوان بكامل اتساعه على دهى

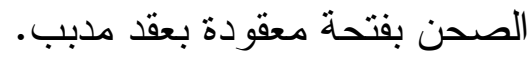
:

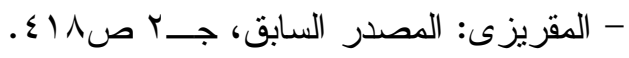

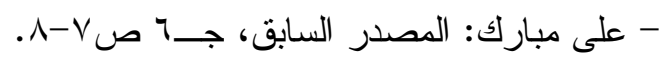

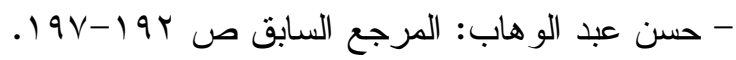

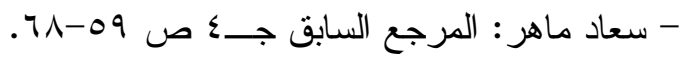

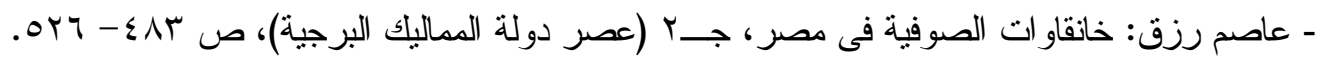
: (TV)

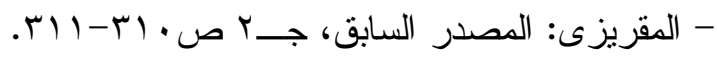

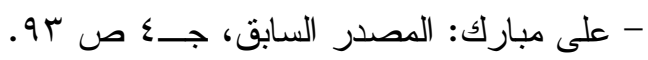

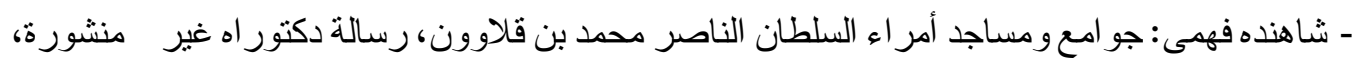

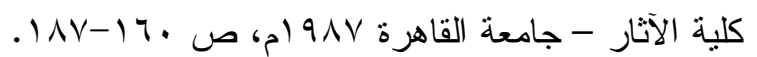
: (7^)

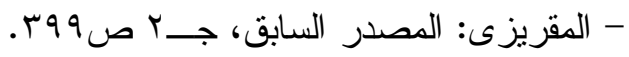

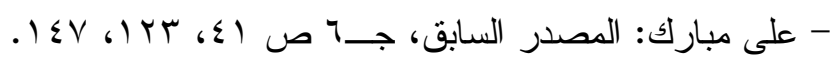

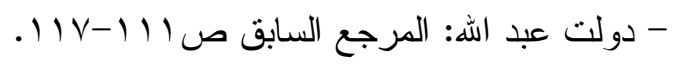

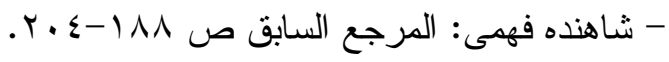

- Williams (C.), Islamic Monuments in Cairo, A Prarctical Guide, Cairo ,1993, PP.99-100.

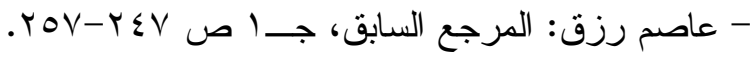

$$
\begin{aligned}
& 1 . \leqslant 0
\end{aligned}
$$


وبالنسبة للإيوان الثمإلى المقابل فهو ايضأ يتكون من مساحة مستطيلة مستعرضة

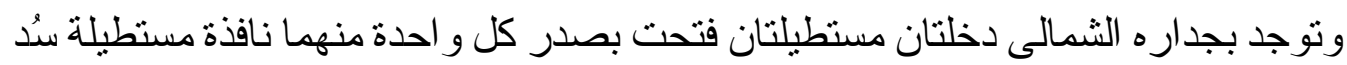

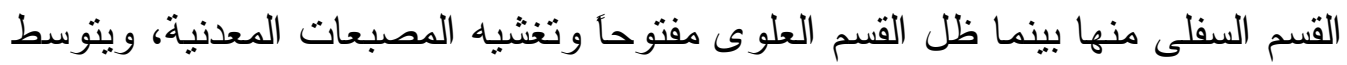

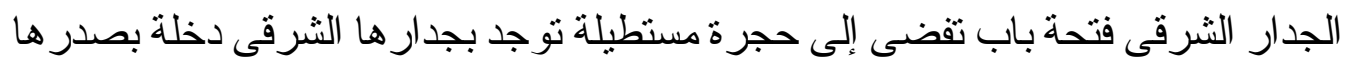

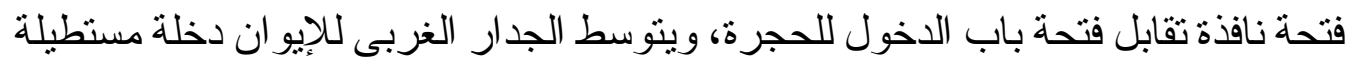

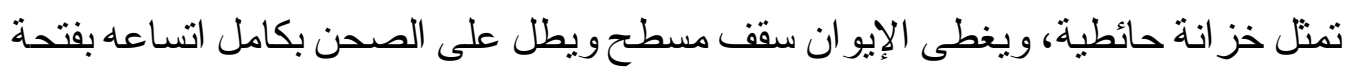
مستطبلة. - منلة

أما الإيو ان الثرقى فهو مستطيل مستعرض توجد بجداره الثرقى دخلة بصدر ها نافذة

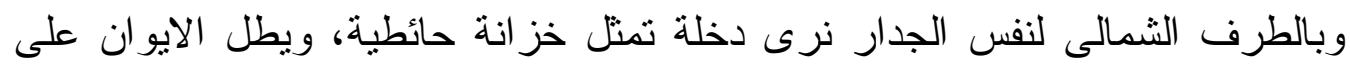

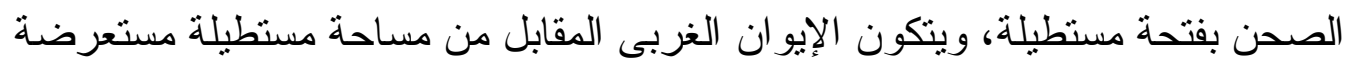

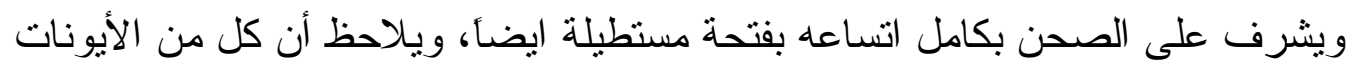

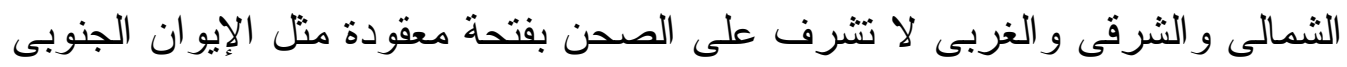
لوجود المبانى المستحدثة فوق هذه الجو انب الثلاث وذلك نظر الثار لاستخدام المدرسة حالياً

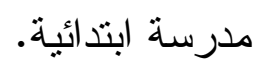

ويتصل الإيوان الغربى من الجهة الثمالية بدهليز الدذخل الرئيسى وهو مستطيل

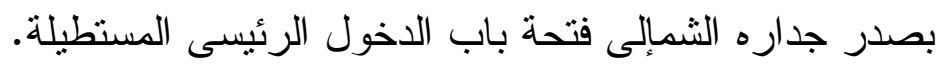

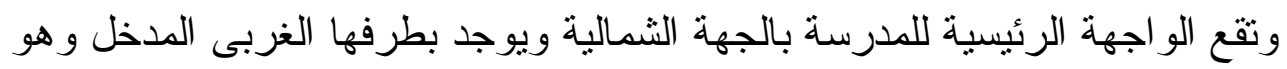

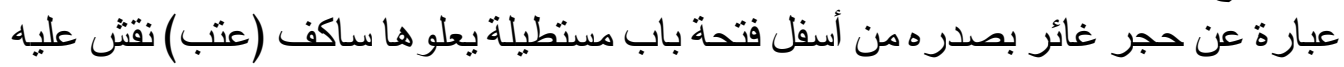

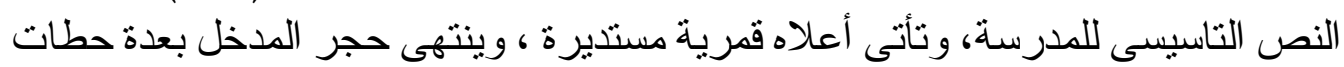

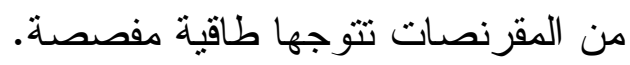

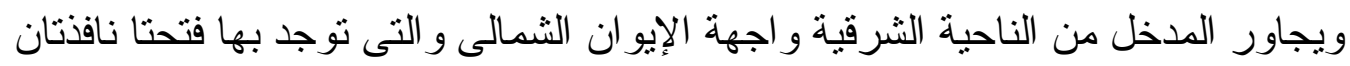
مستطيلتان سُد القسم السفلى منهما بينما ظل القسم العلوى مفتوحأ وغشيت فتئ فتحتا النافذتين بمصبعات معدنية.

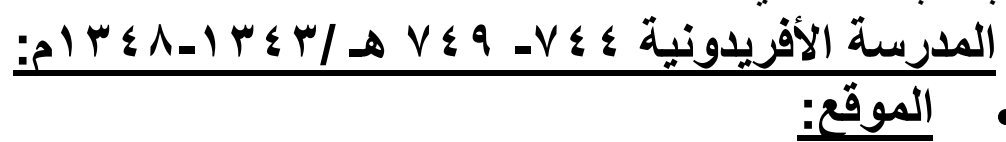
شرقى جامع حسان خار جباب الجابية بالثار ع الأعظم غربى خندق سور المدينة قريباً

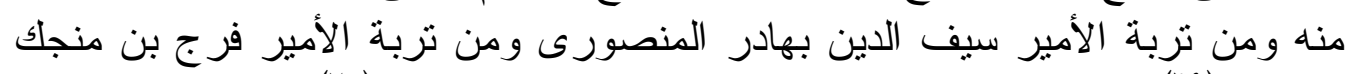

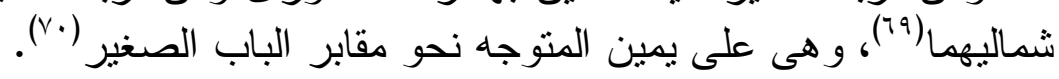

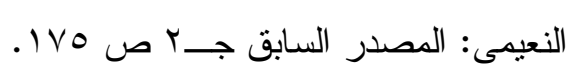




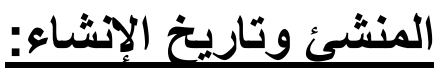

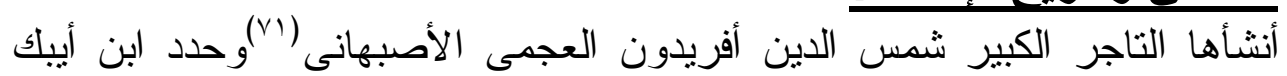

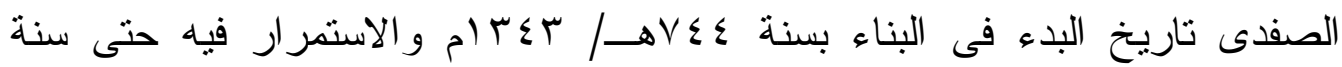

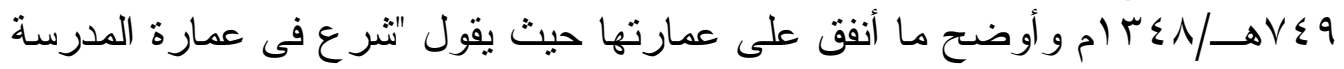

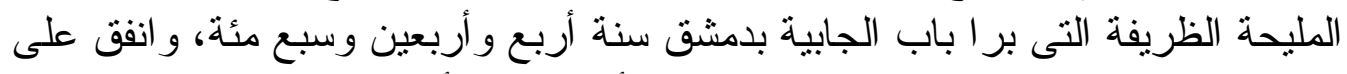

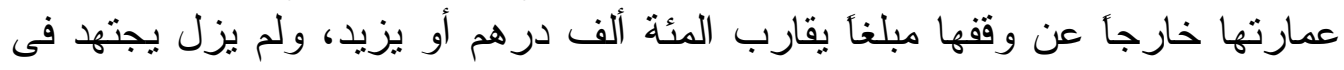

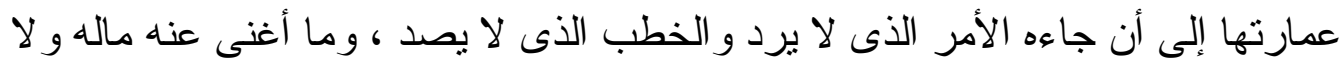

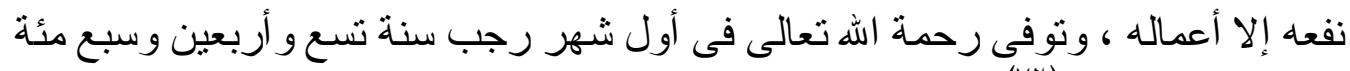

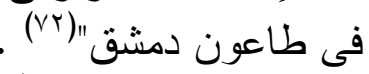

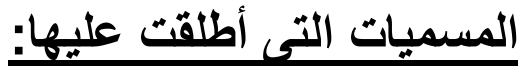

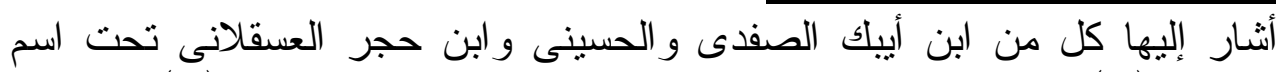

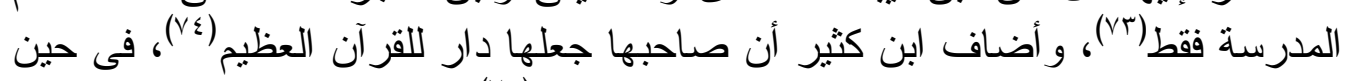

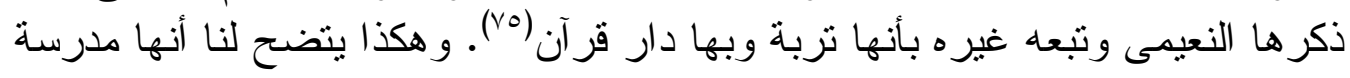

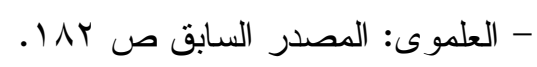

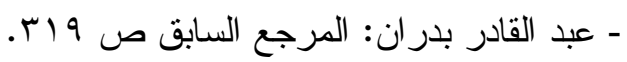

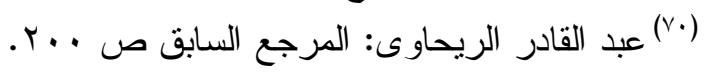

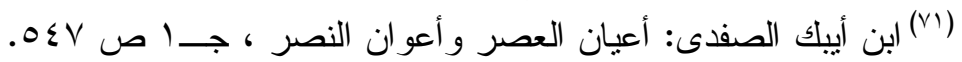

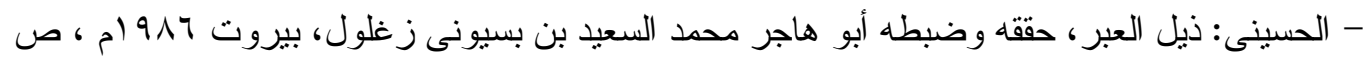

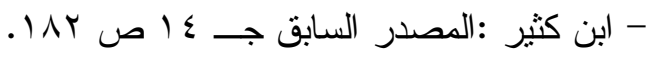

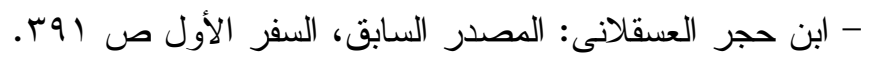

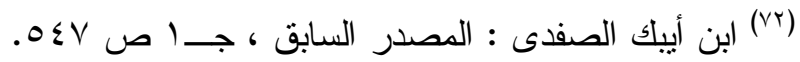

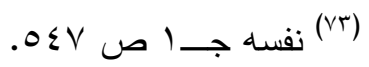

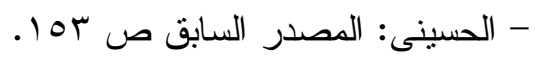

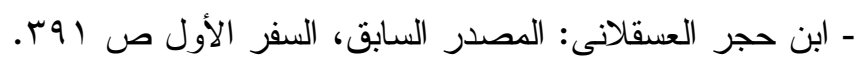

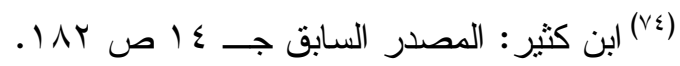

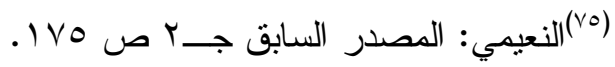

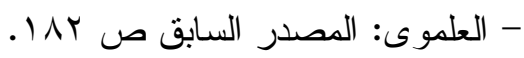


قامت أيضاً بوظيفة دار القر آن وتوجد بها تربة للافن.

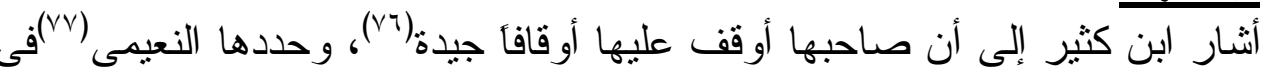

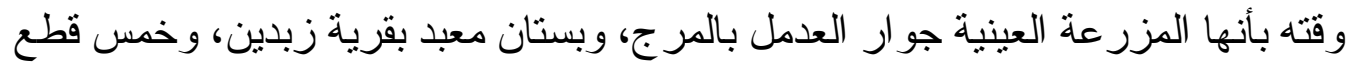

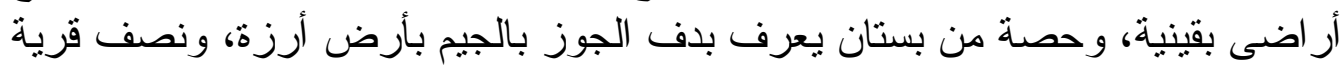

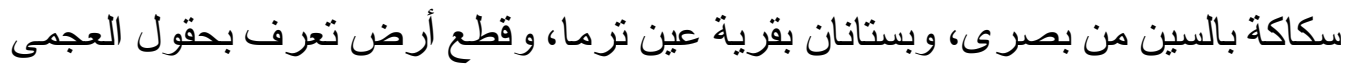

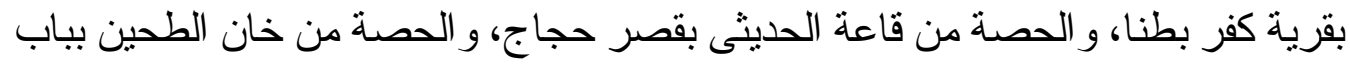

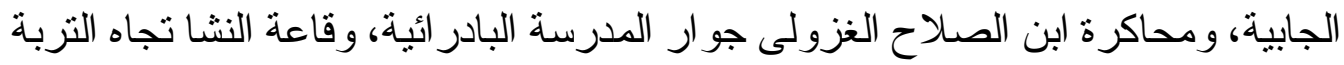

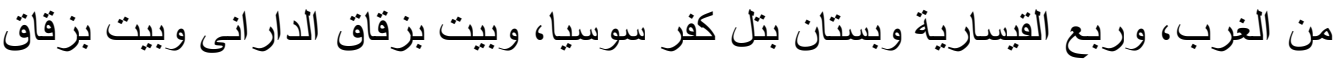

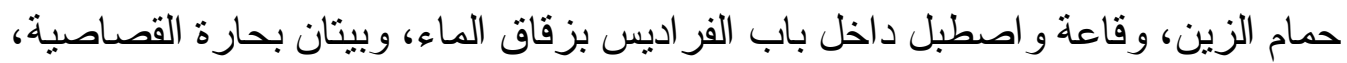

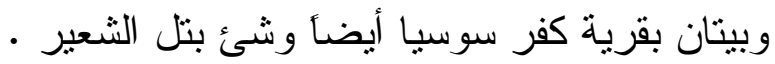

\section{تناول المؤرخين والباحثين لها:}

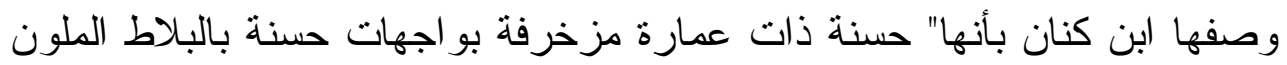

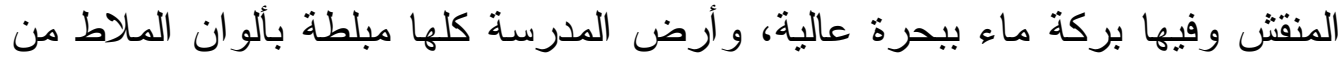

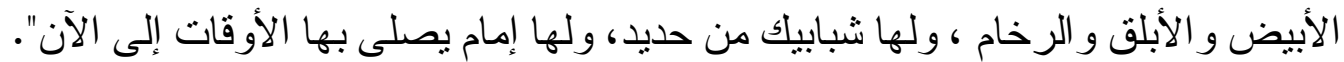

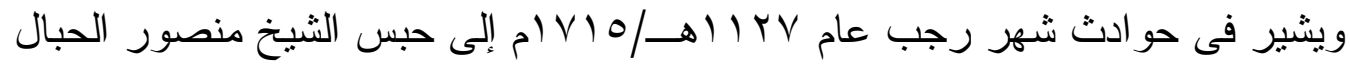

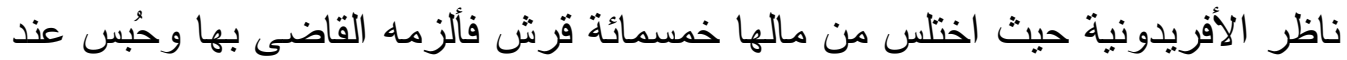

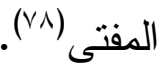

وذكر ها ولتسينجر تحت اسم جامع العجمى وضريح الثيخ محمد العجمى و أضاف

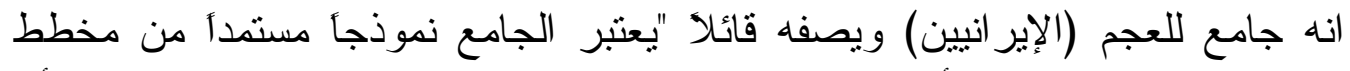

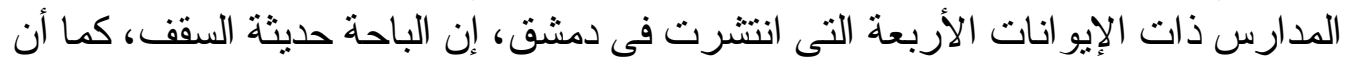

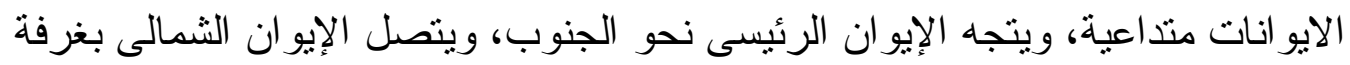

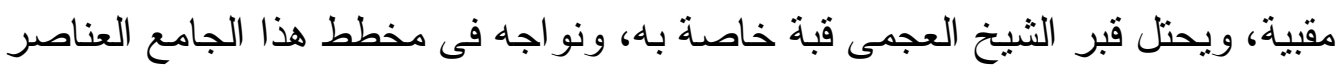

- عبد القادر بدران : المرجع السابق ص 9 اس إ.

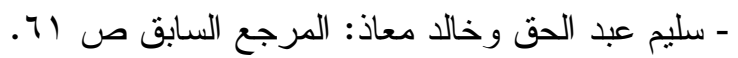

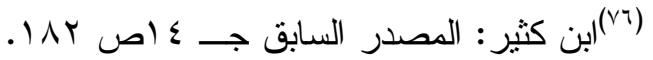

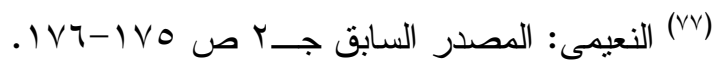

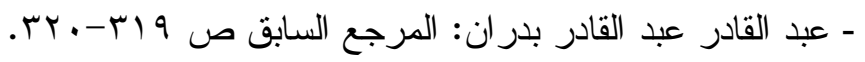

(YN) 
الر افدية القديمة الثلاثة (أي الباحة و الإيو ان و القبة)، وينكسر دهليز الدذخل مرنين، كما يملاً

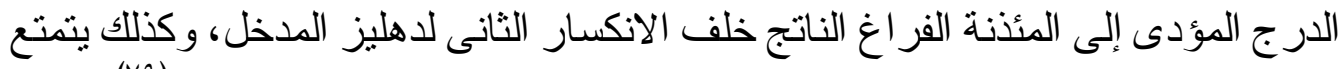

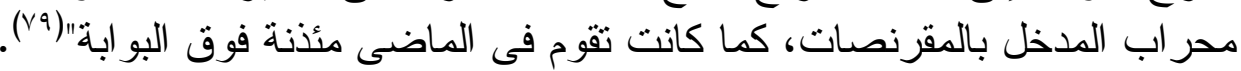

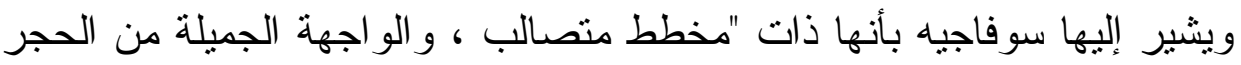

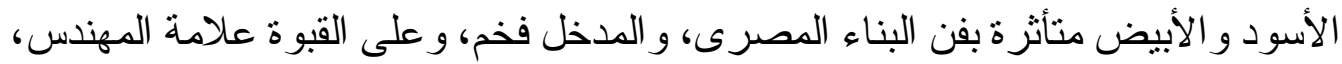

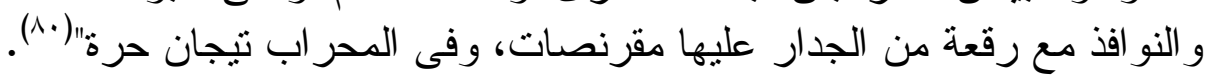

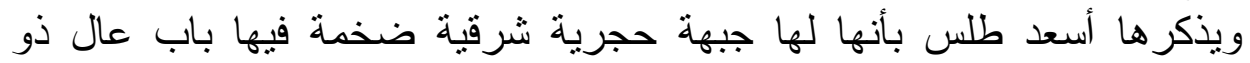

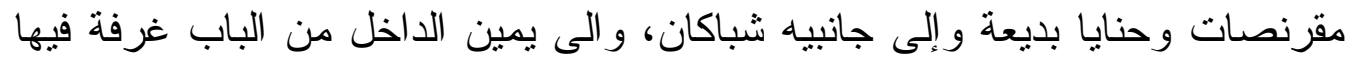

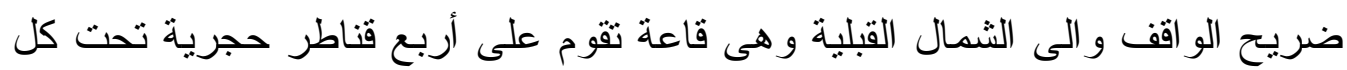

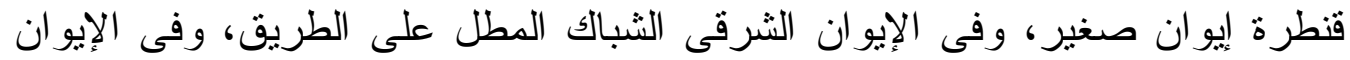

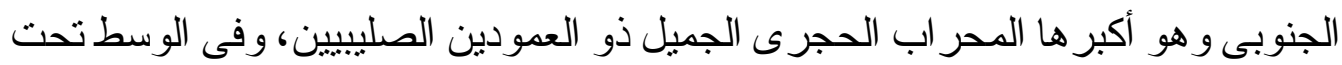
القبة بركة مربعة يجرى إليها ماء القنو ات" (1).

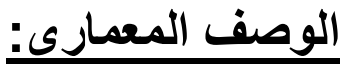

تتكون المدرسة من صحن أوسط مربع كثنف سماوى كانت توجد به به بحرة (فسقية)

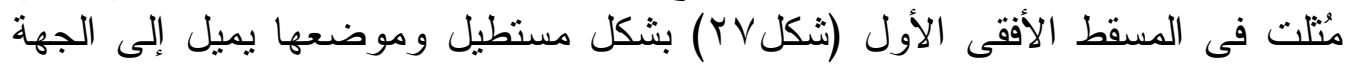

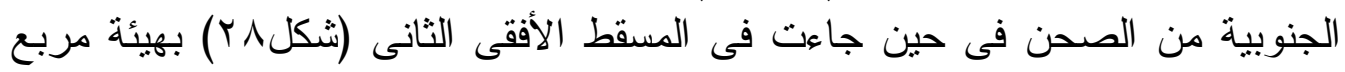

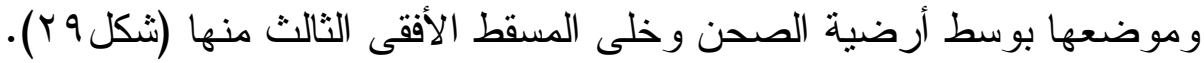

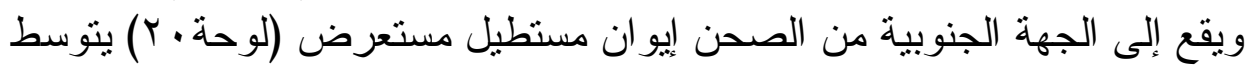

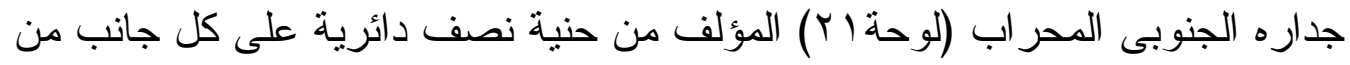

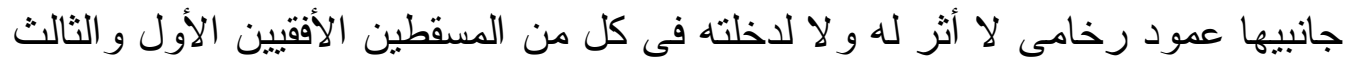

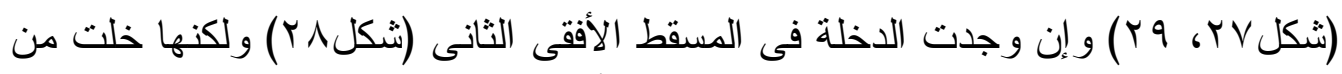

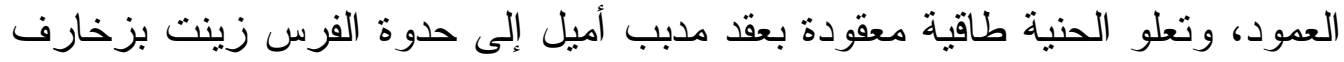

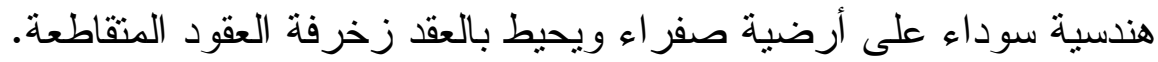

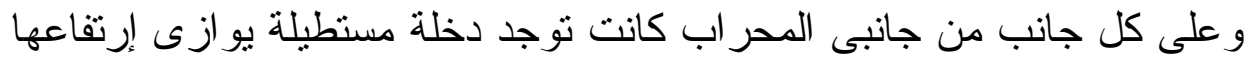

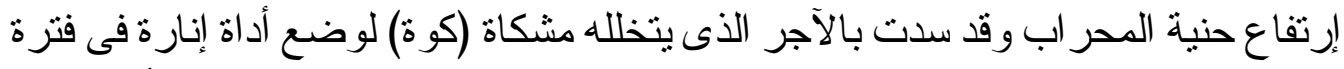

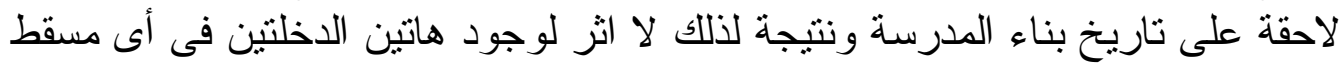

كارل ولتسينجر : المرجع السابق ص ع IV9) (^)

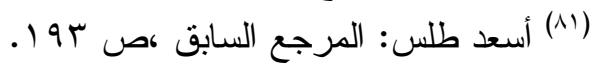


من المساقط الأفقية الثلاثة للمدرسة.

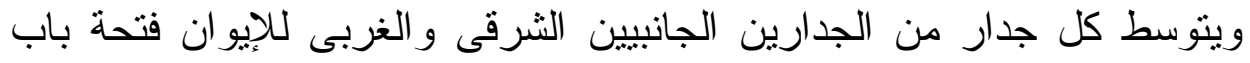

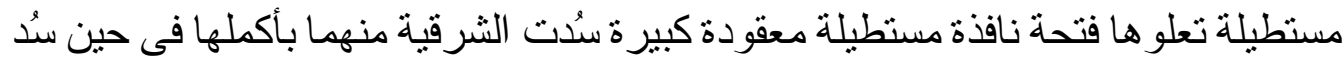

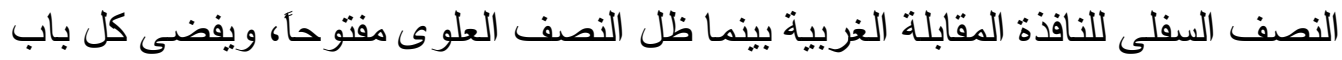

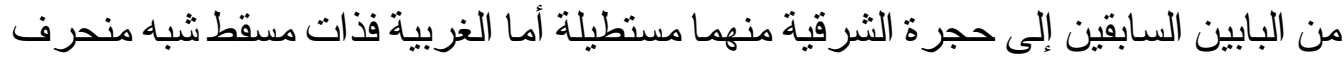

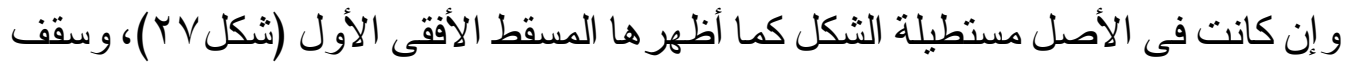

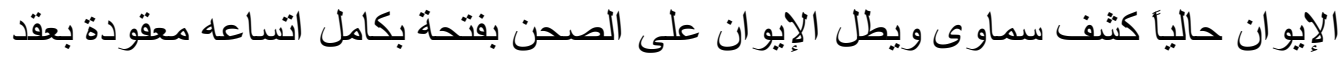
مدبب حدوة فرس (لوحة بالب).

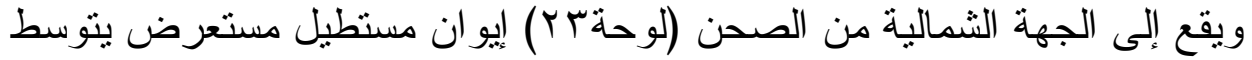

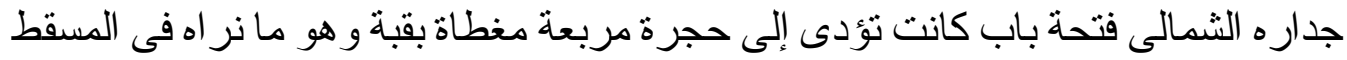

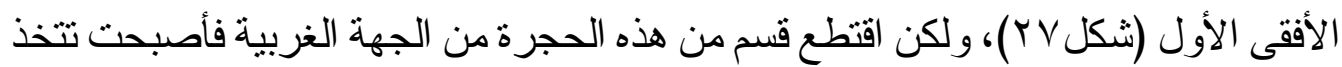

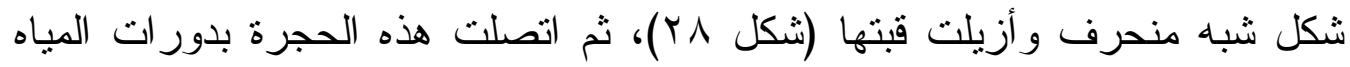

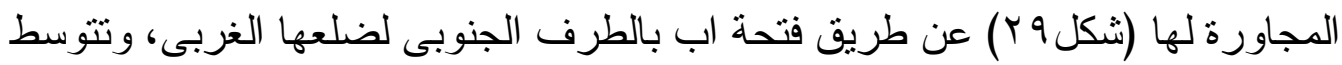

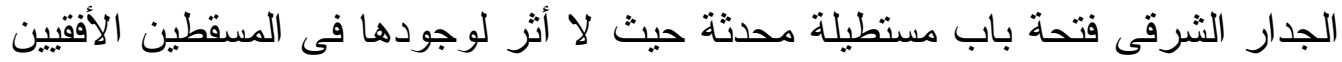

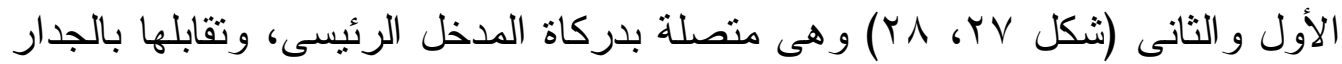

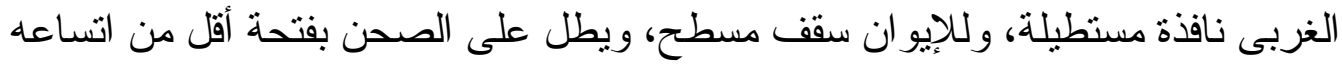

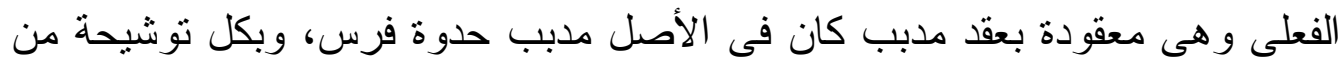
توشيحتى العقد نجد نافذة مستطيلة حديثة.

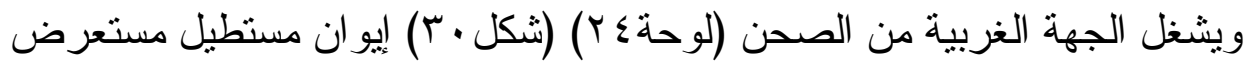

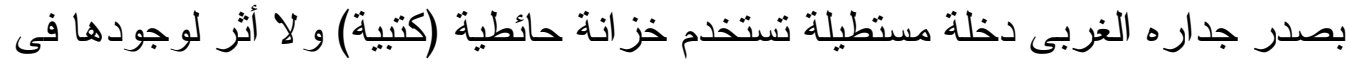

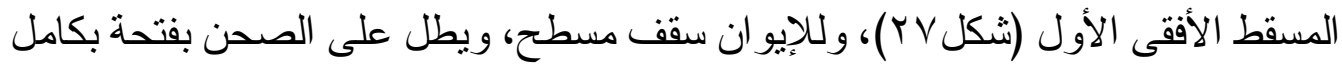

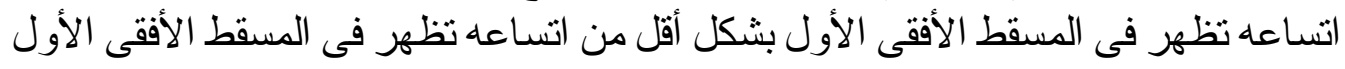

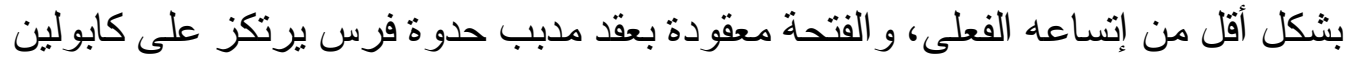

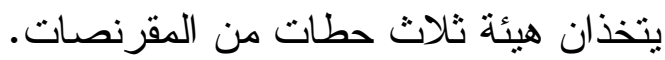

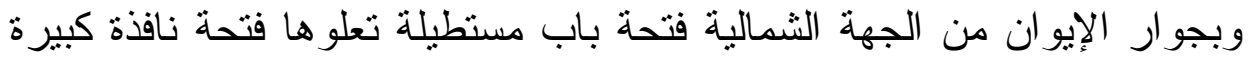

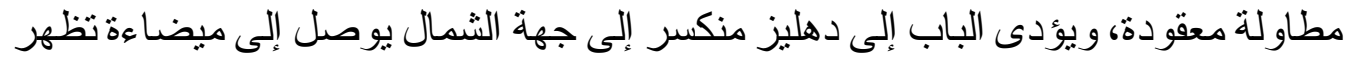

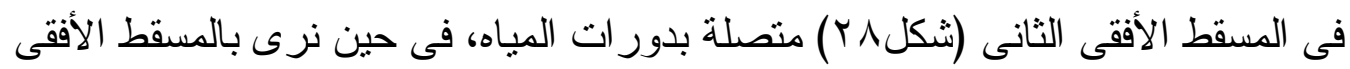

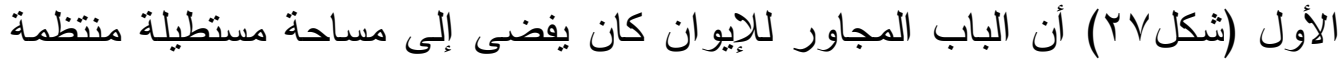

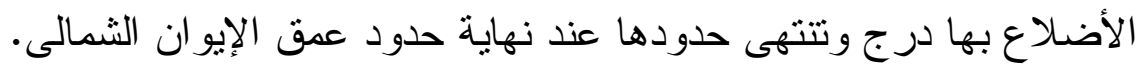


ويقع بالجهة الثرقية من الصحن (لوحةهب) إيوان مقابل للإيوان الغربى وهو

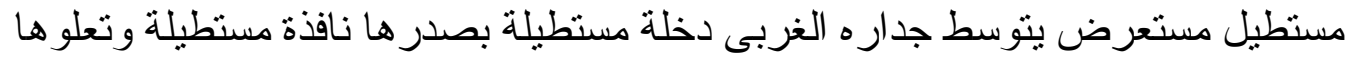

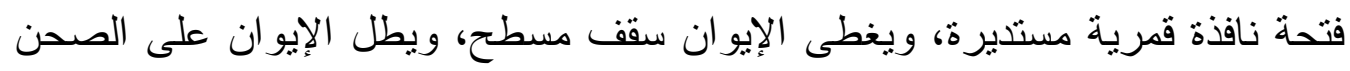

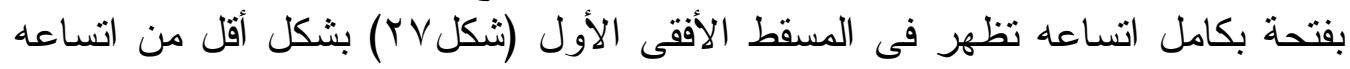
الفعلى، و الفتحة معقودة بعقد مدبب حدوة فرس برتكز الفكز على كابولين يتخذان هيئة ثلاث

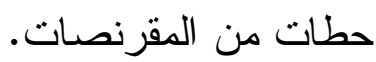
ويجاور الإيو ان من الناحية الثمالية فتحة باب مستطيلة مسدودة حديثً (حيث حلت

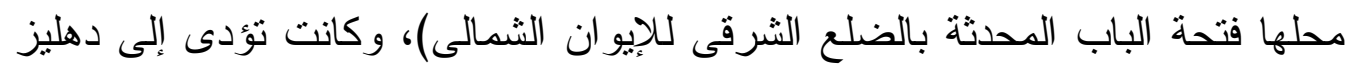

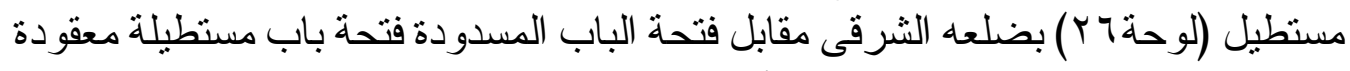

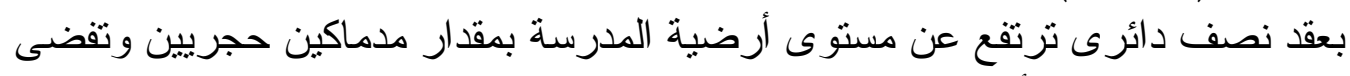

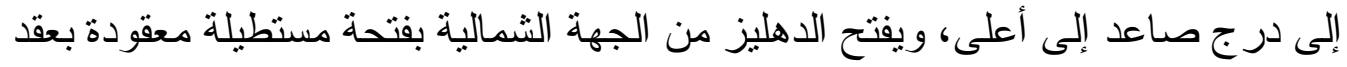

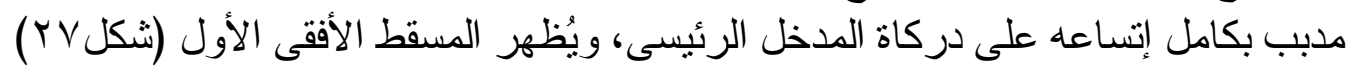

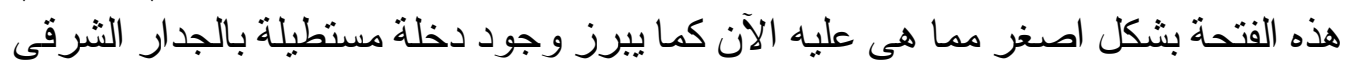

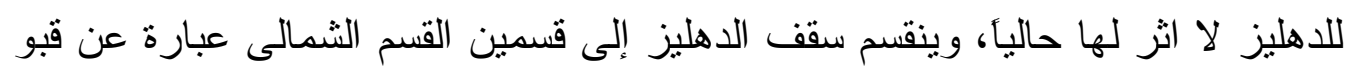

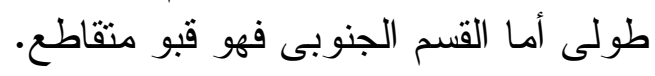
وبالنسبة لدركاة المدخل الرئيسى فهى مستطيلة تفتح من الجهة الجنوبية على الجئ الدهليز

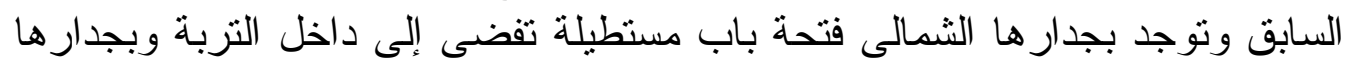

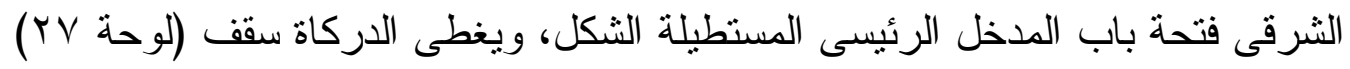

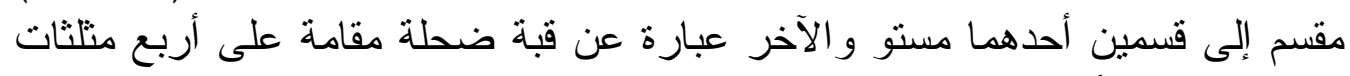

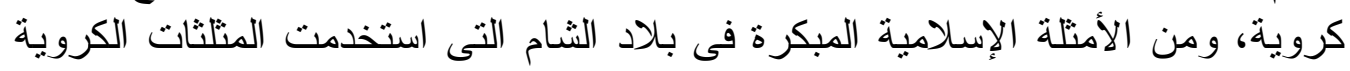

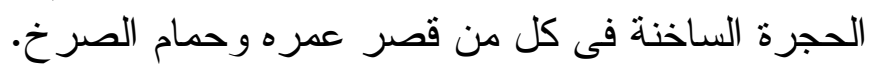

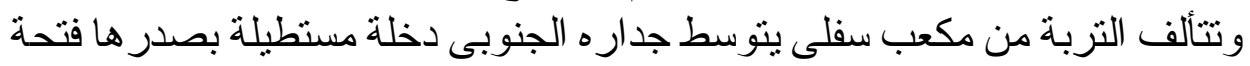

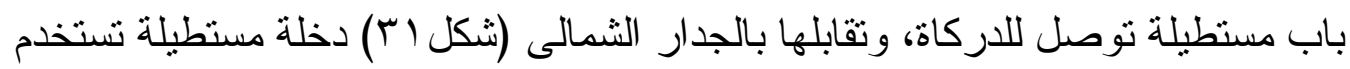

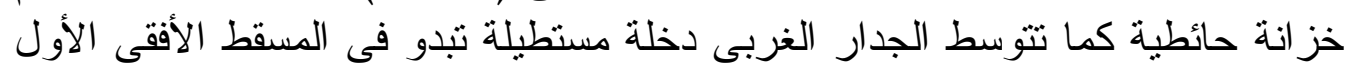

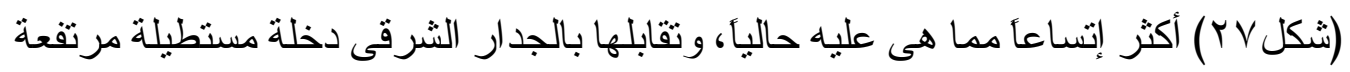

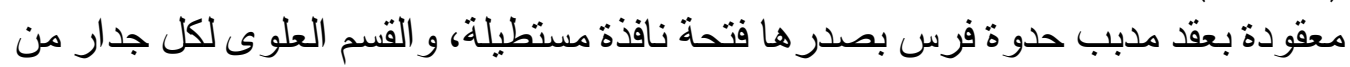

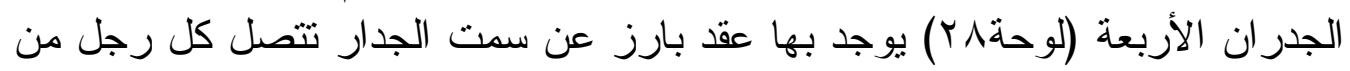

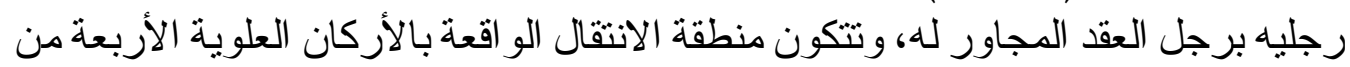

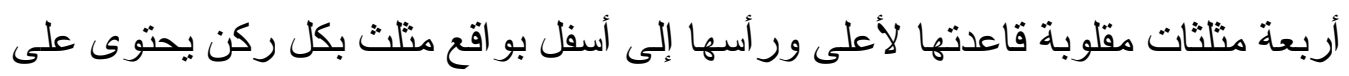


أربع حطات من المقرنصات، ومن الأمتلة الباقية لاستخدام المقرنصات في مناطق انتقال

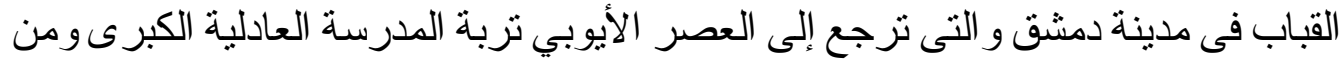

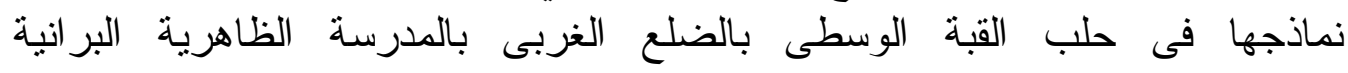

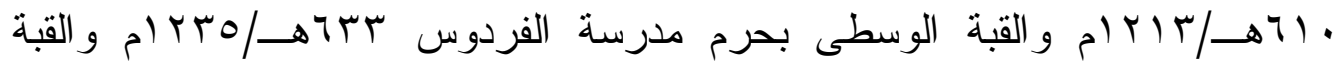

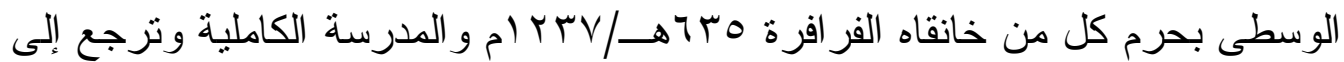

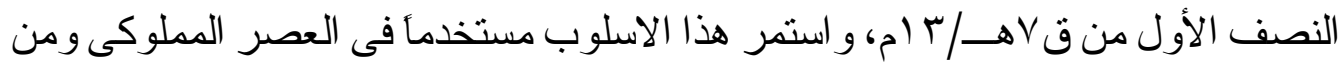

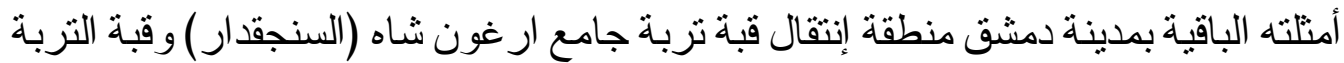

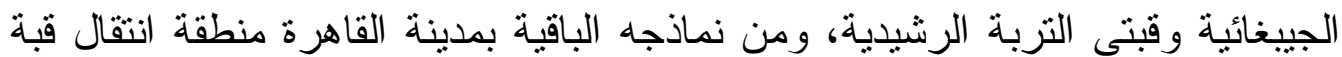

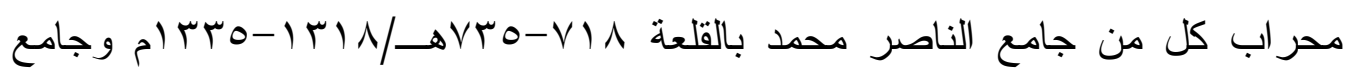

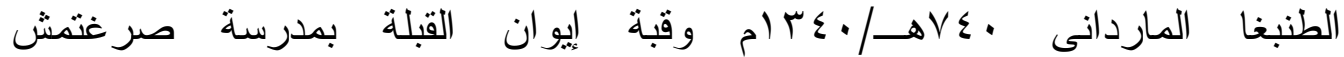
وفه هOVVV وقبة مدفن مدرسة الظاهر برقوق

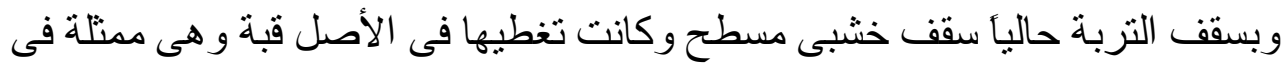

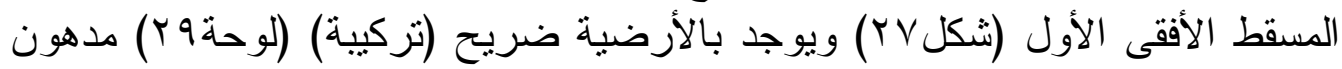

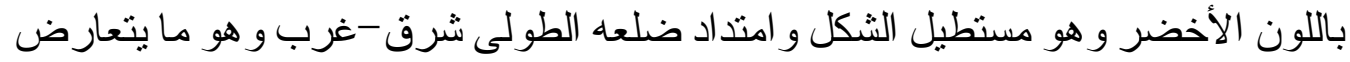

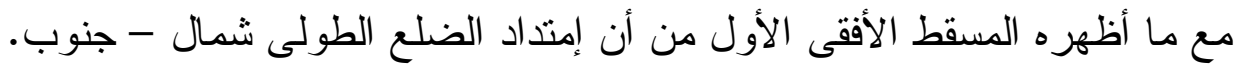

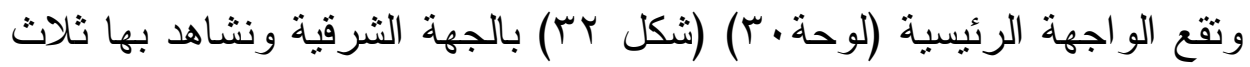

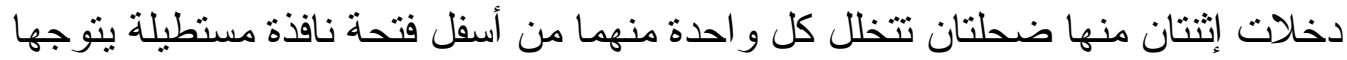

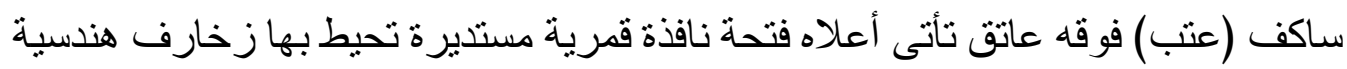

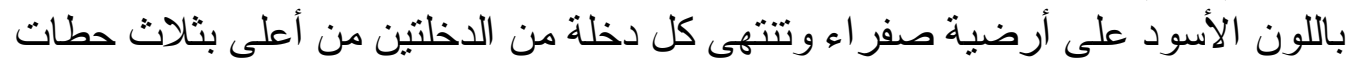

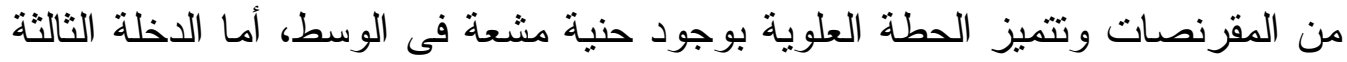

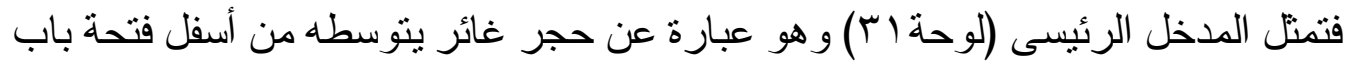

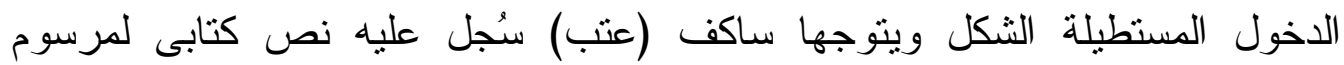

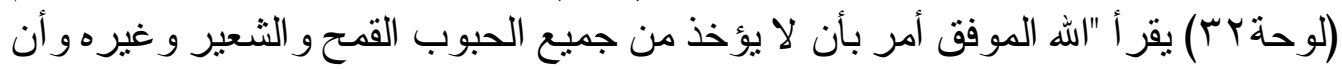

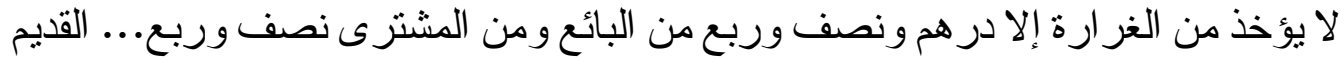

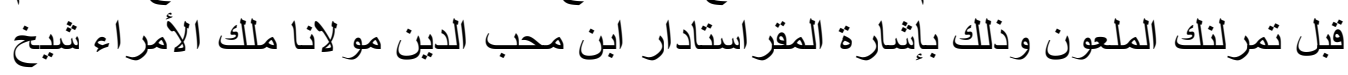

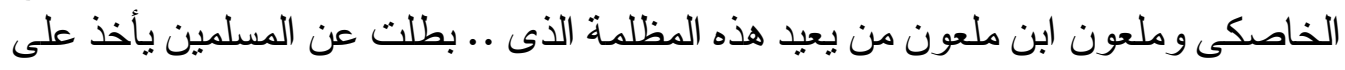

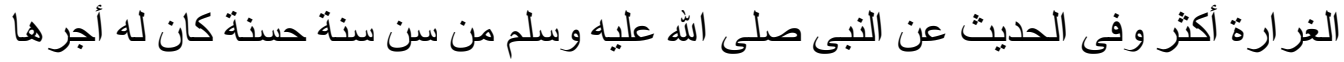

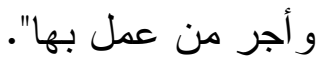


ويأتى فوقه عقد عاتق يليه شكل مربع زخرفى (لوحة وسج) تجمع زخارفه بين

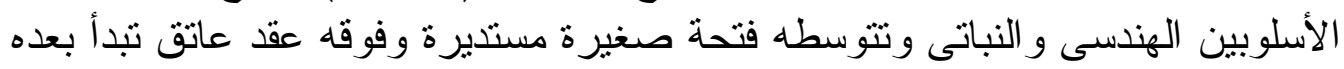

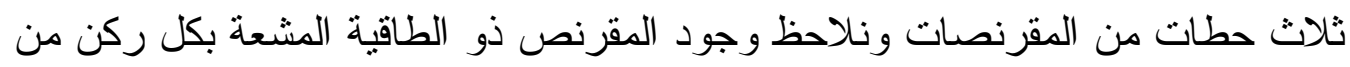

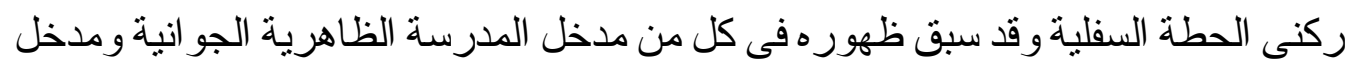

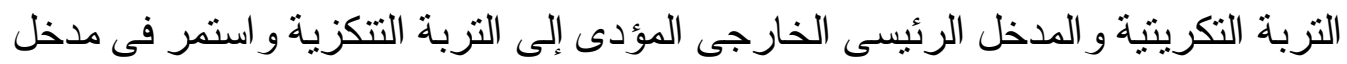

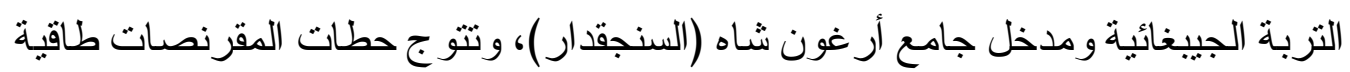
معقودة زينت بثلاثة أثكال لوزية.

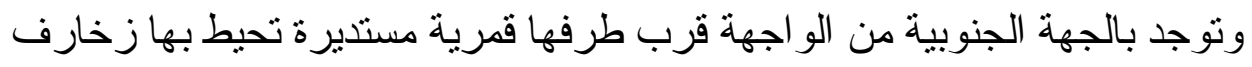

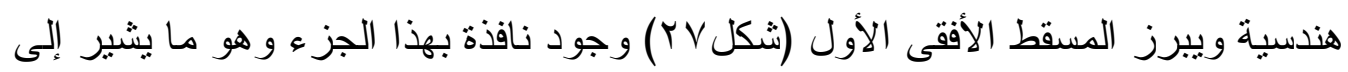

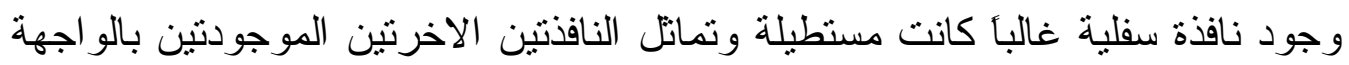

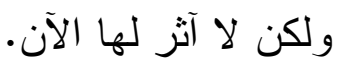

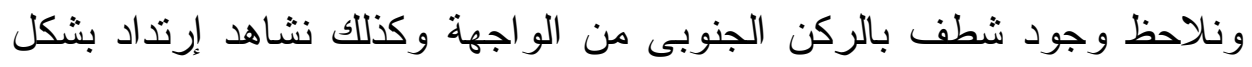

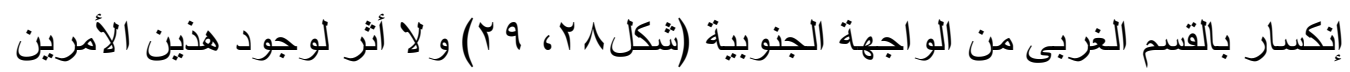

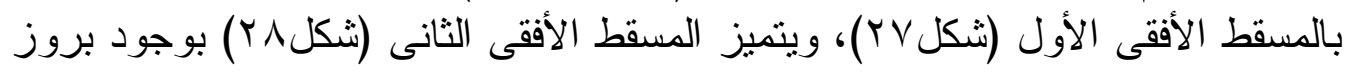
خلف حنية المحر اب وهو ما لا نجده بالمسقطين الأفقيين الآخرين. 
ويعد فقد إنتهى هذا البحث إلى إيراز عدة نتائج أوضحها في النقاط الآتية:

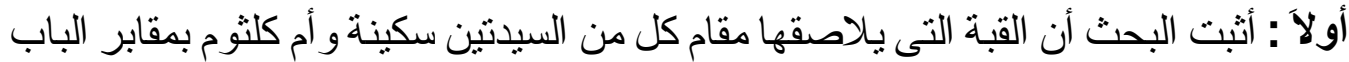

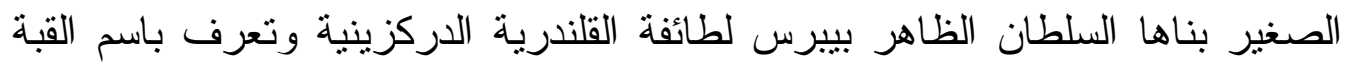

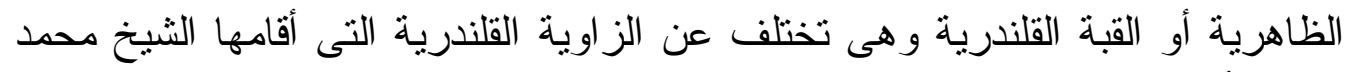
البلخى أحد شيو خ طائفة القلندرية الدركزينية وكانت تقع إلى النى جو ارها.

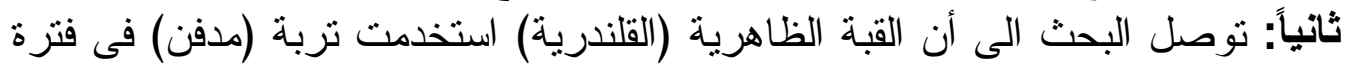

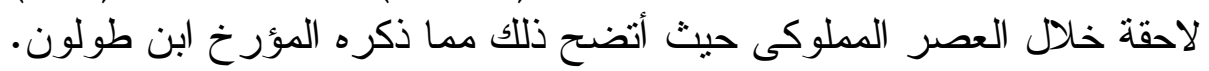

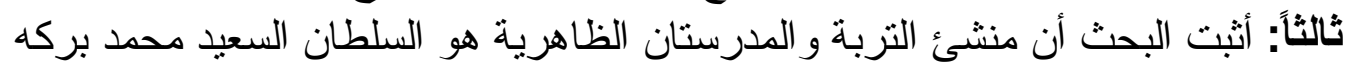

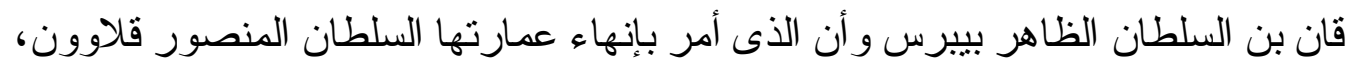

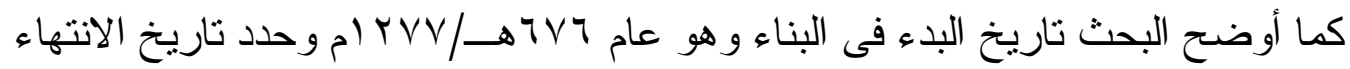

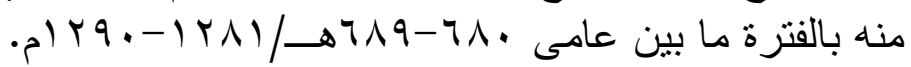

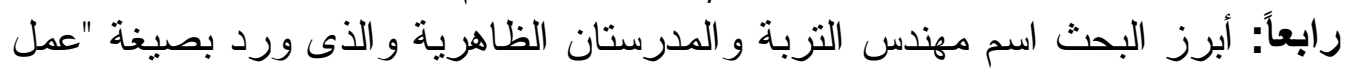

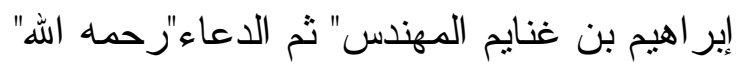

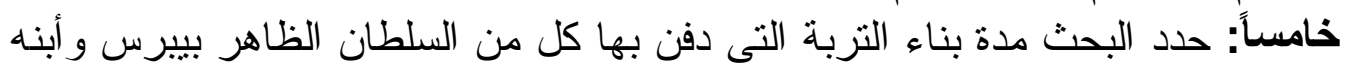

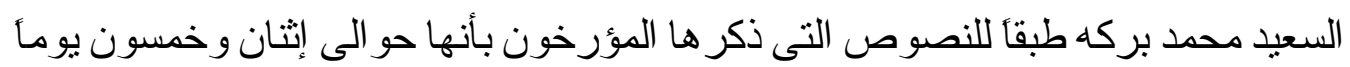

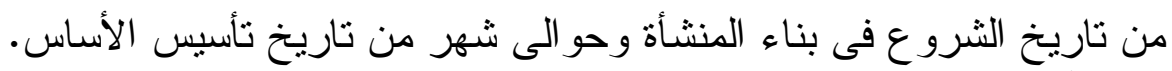

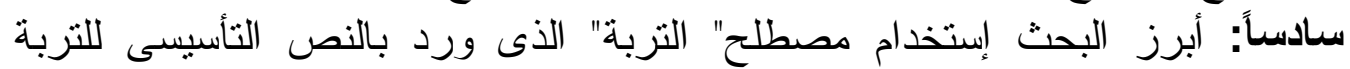

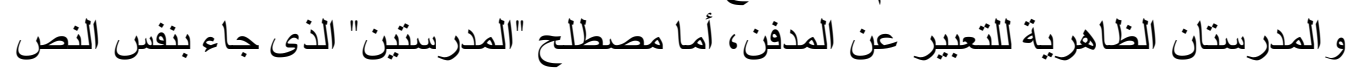

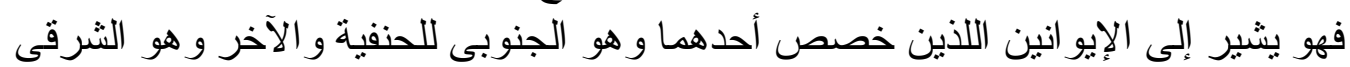

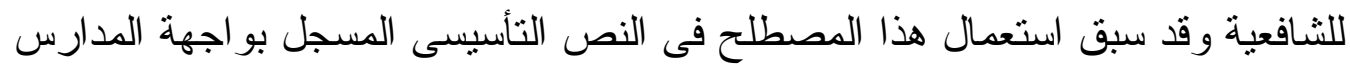

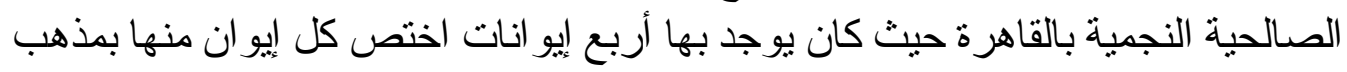
من الدذاهب السنية الأربعة لذلك استخدمت في تسميتها صيغة الجمع فأطلق عليها لئها

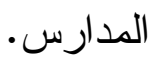

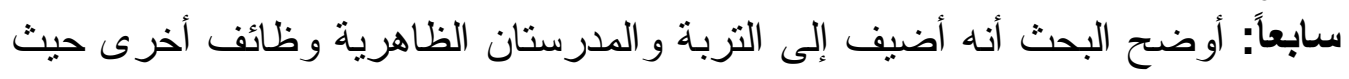

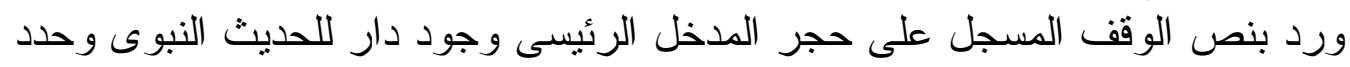

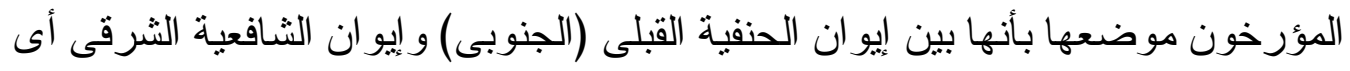

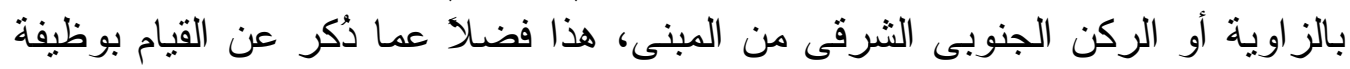

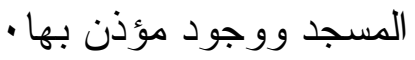
ثامناً: أثنار البحث إلى قيام المدرسة التتكزية بوظيفة دار للقر آن وللحديث النبوى و الى اسم 
المشرف على البناء الذى ورد بالنص التأسيسى بصيغة" بمباشرة العبد الفقير أيدمر

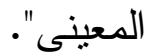
تاسعاً: حدد البحث تاريخ بناء المدرسة الأفريدونية حيث كان البهاء فئه في عام

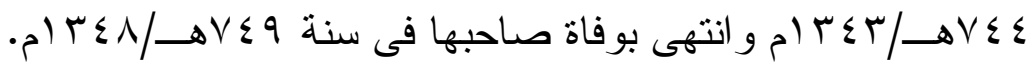
عاشر اً: أوضح البحث قيام المدرسة الأفريدونية بوظيفة دار القر ان كما استخدمت كمسجد

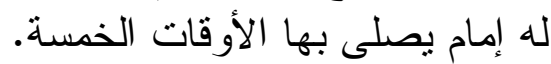
حادى عشر: أبرز البحث تسجيل الأوقاف على جدران الأن العمائر كما فى التربة و المدرستان

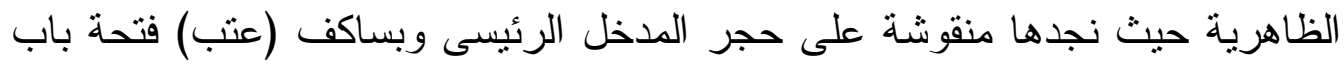

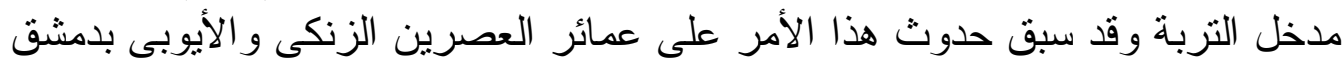

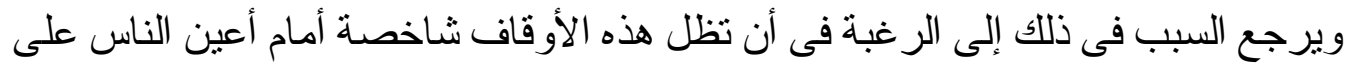
مر العصور ورغم ذلك فلم تسلم أوقاف العمائر من التلاعب أو أو الاستيلاء عليها حيث ألثان أنثار

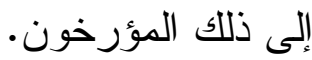

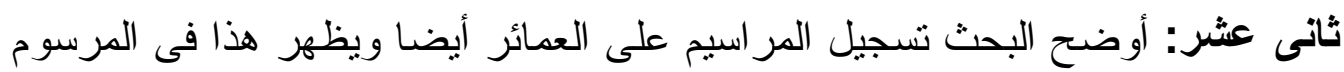

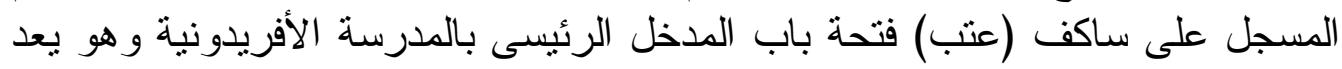

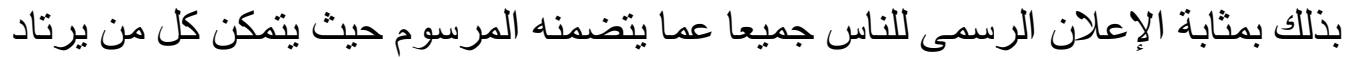

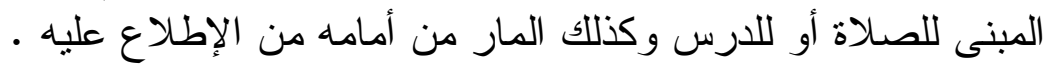


دراسات في آثار الوطن العربي ؛

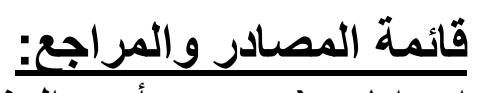

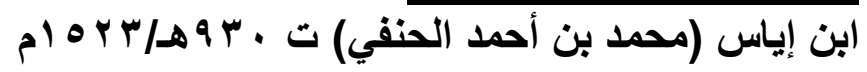

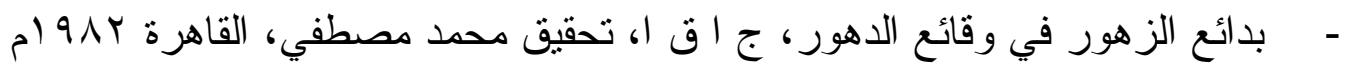
البدرى (أبى البقاء عبد الله): -

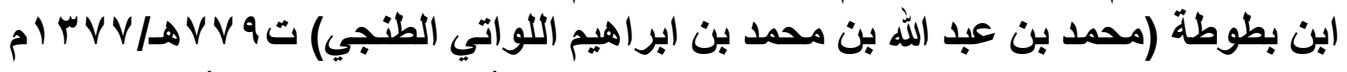

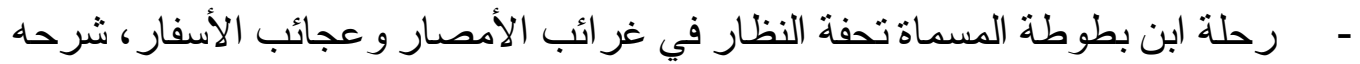

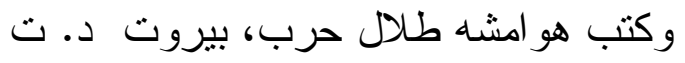

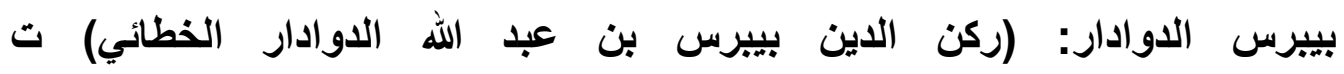

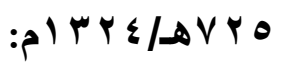
- زبدة الفكرة في تاريخ الهجرة ( عصر سلاطين المماليك) ، تحقيق د. ز زبيدة محمد عطا،

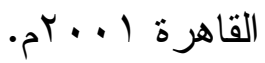

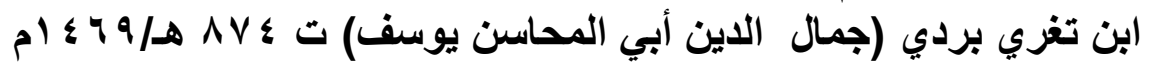

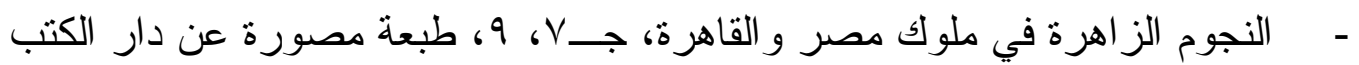

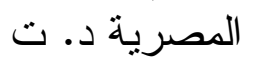

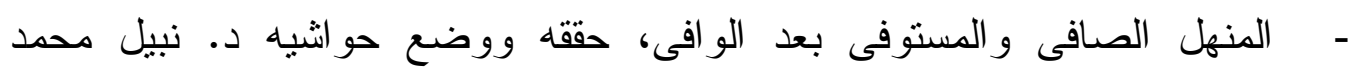

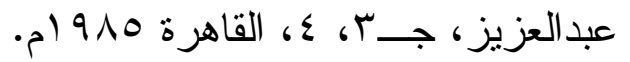

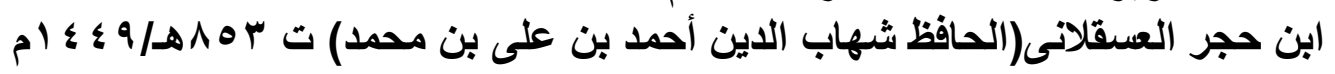

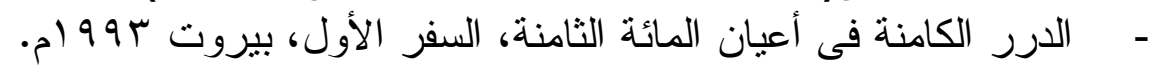

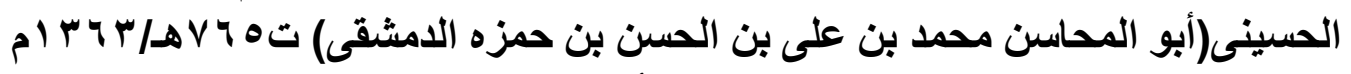

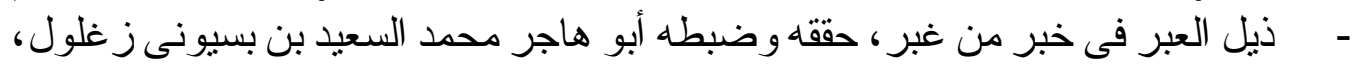

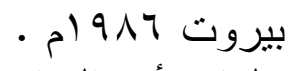

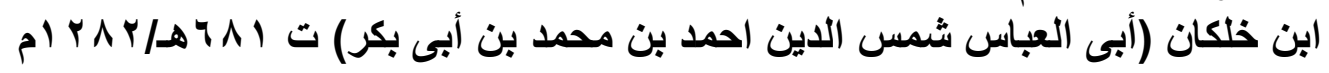

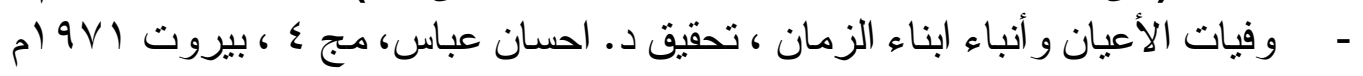

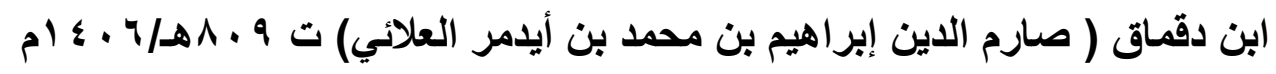

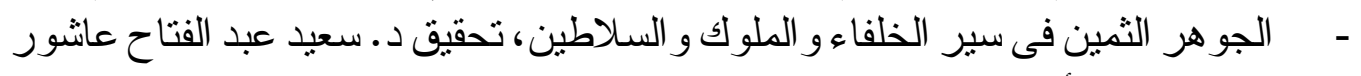

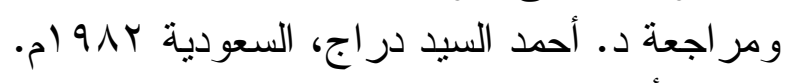

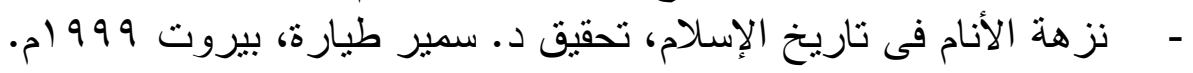


دراسات في آثار الوطن العربي ؛

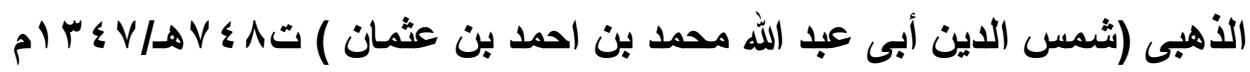

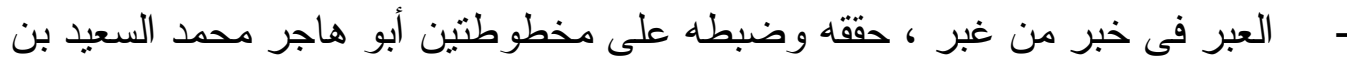

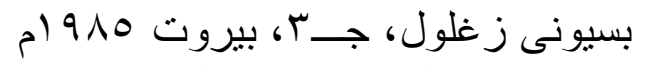

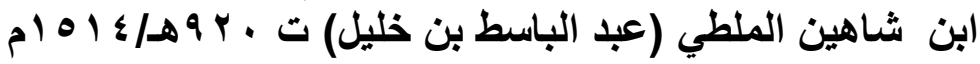

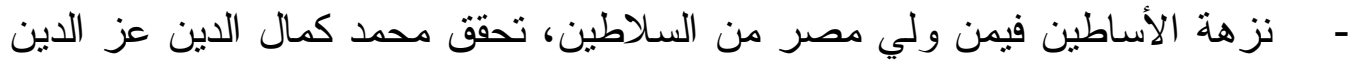

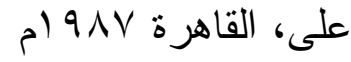

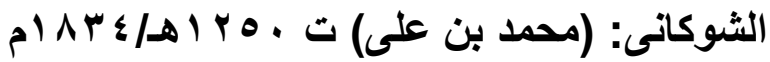

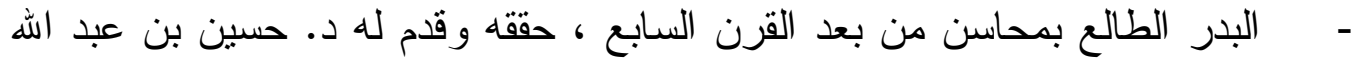

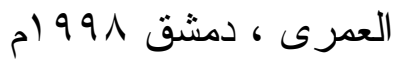

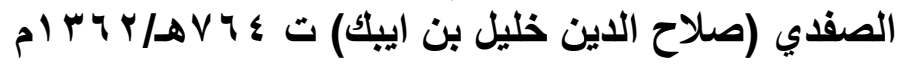

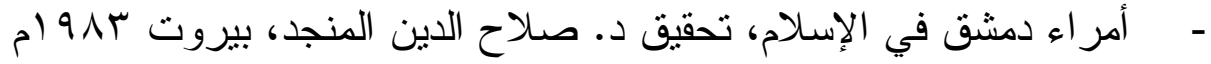

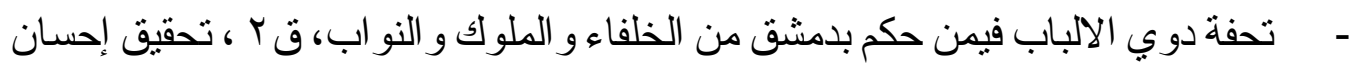

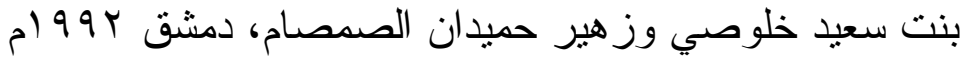

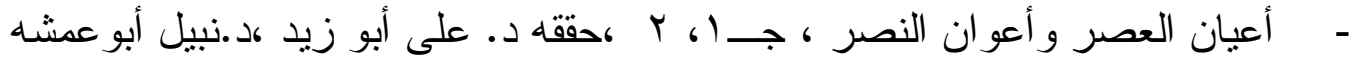

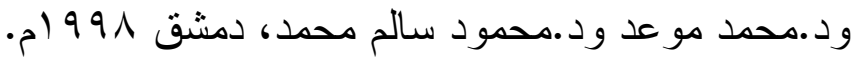

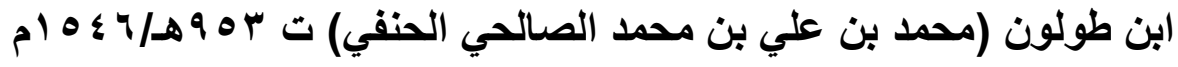

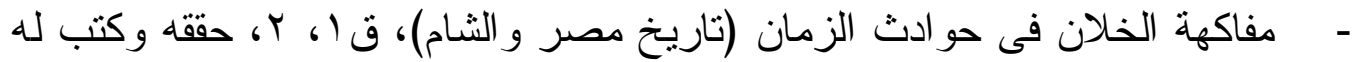

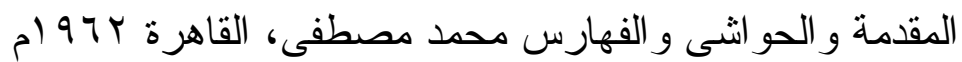

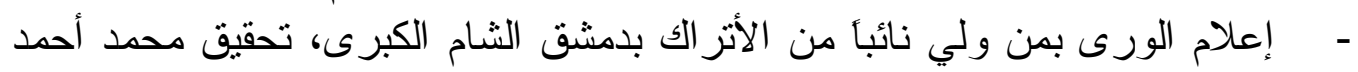

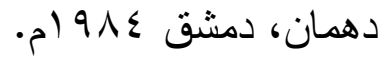

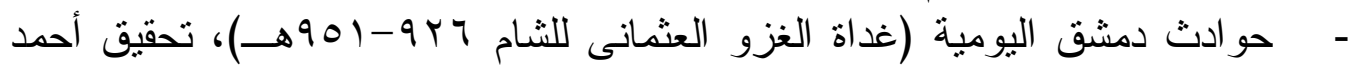

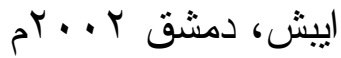

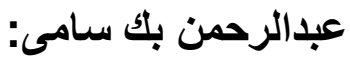

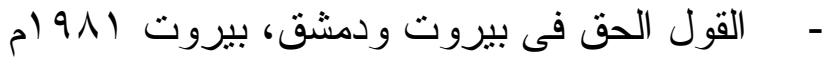

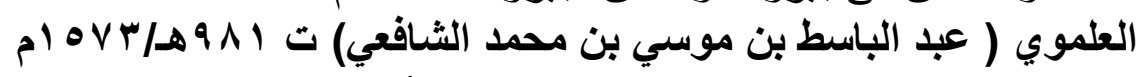

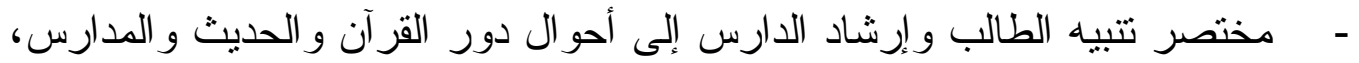

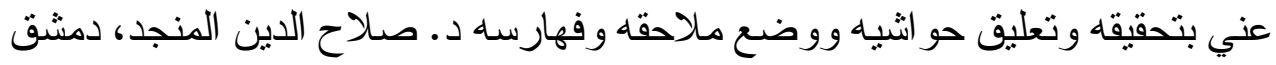

$$
\text { على مبارك : } 9 \text { ام }
$$

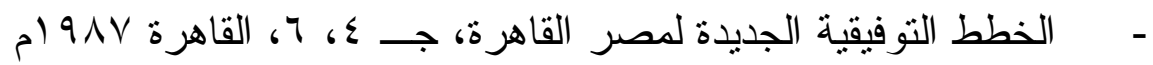


دراسات في آثار الوطن العربي ؛

ابن العماد (شهاب الدين ابي الفلاح عبد الحي بن احمد بن محمد العكري الحنبلي

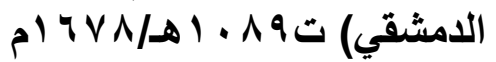

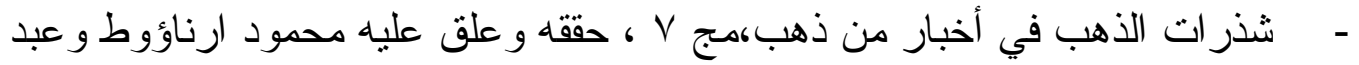

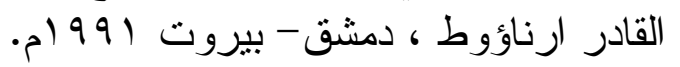

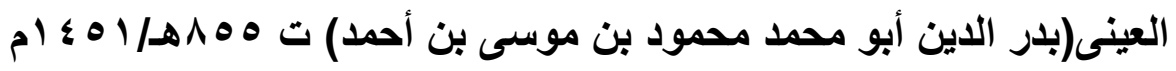

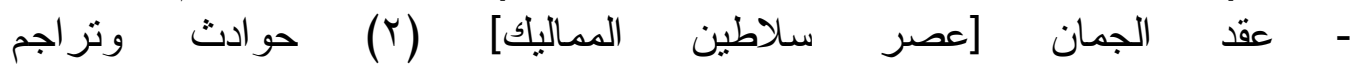
 .01911

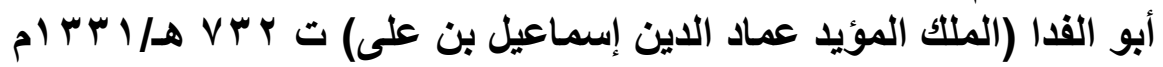

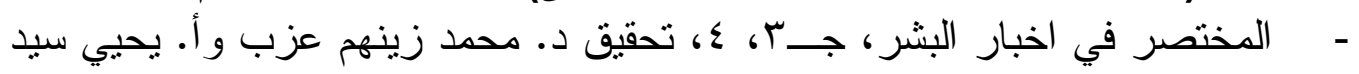

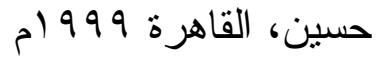

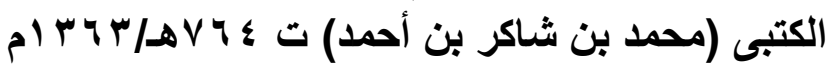

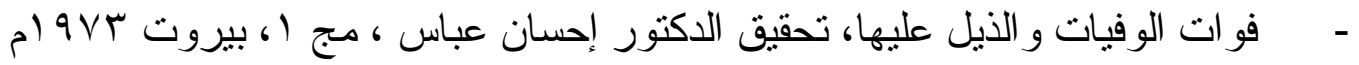
ابن كثير (اسماعيل بن عمر بن كثير بن ضو النو بن كثير بن درع القرشي) ت إن

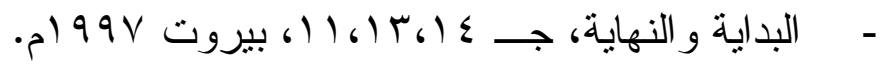

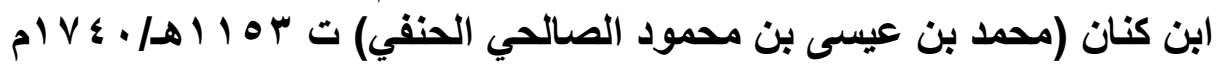

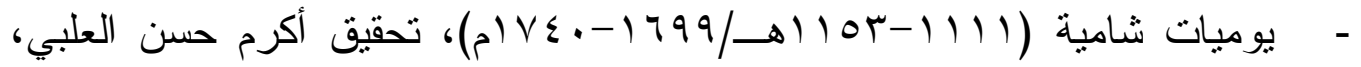

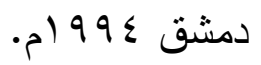

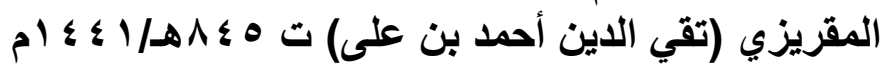

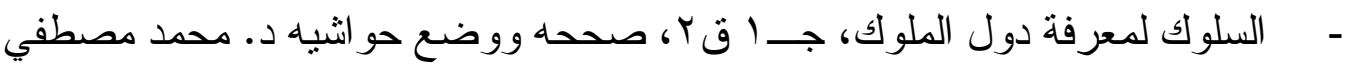

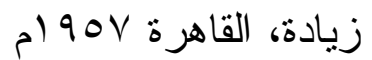

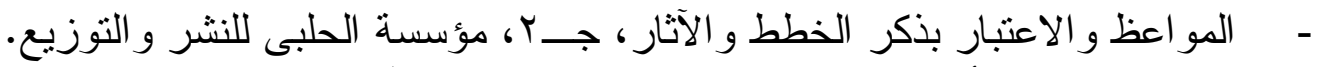

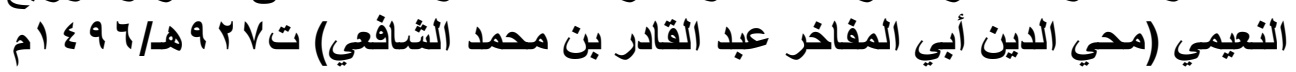

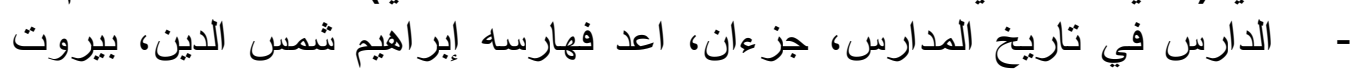
199.

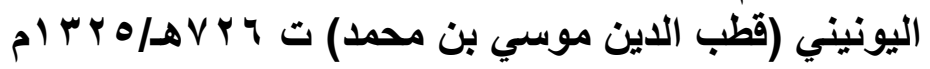

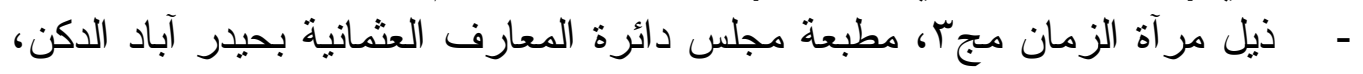

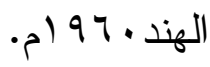


دراسات في آثار الوطن العربي ؛

\section{أحمد عبد الرازق (دكتور): المراجية و الرسائل العلمية:}

- الرنوك على عصر سلاطين المماليك، بحث في المجلة التاريخية المصرية، العدد ابل،

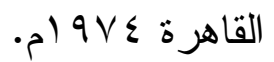

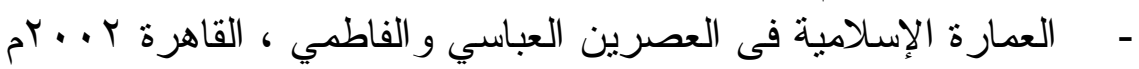

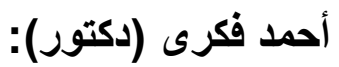

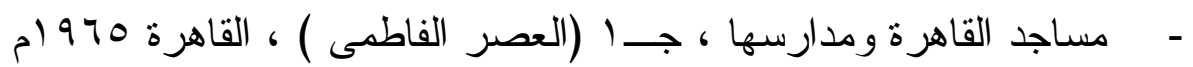

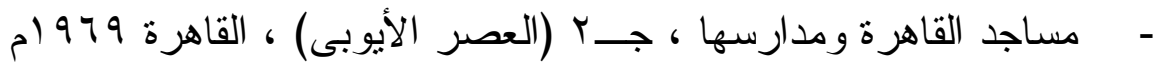

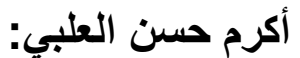

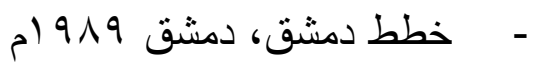

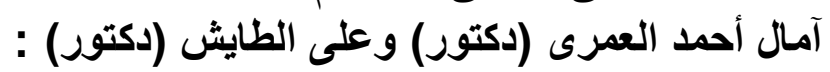

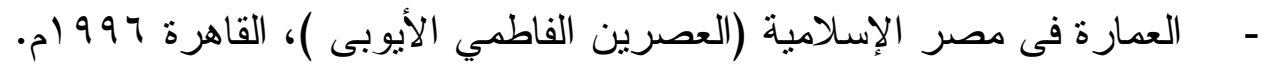

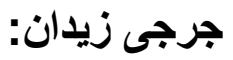
- - دمشق الثام (تاريخها و آثارها و أحو الها الاجتماعية و الاقتصادية و العلمية)، مقال

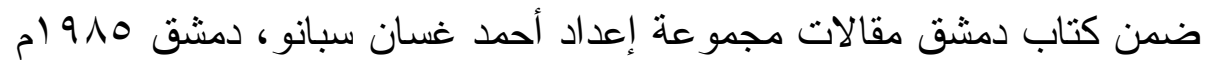

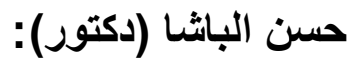

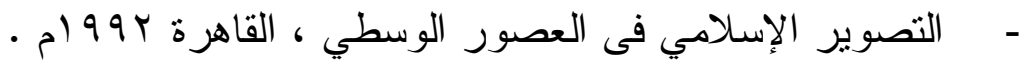
حسن سيل جوده القصاص (دكتور): - الددرسة الصر غتمشية، مخطوط رسالة ماجستير غير منشورة، كلية الآداب -جامعة

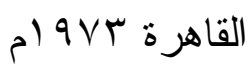

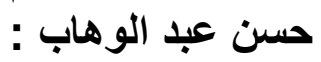

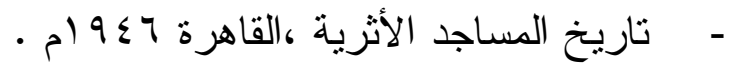

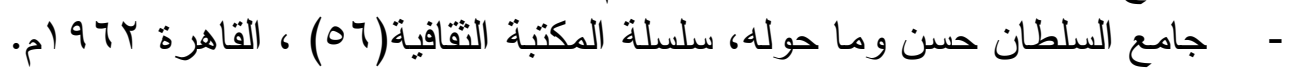
حسنى محمد نويصر (دكتور): - العمارة الإسلامية في مصر (لوكر): (عصر الأيوبيين و المماليك) ، القاهرة 997 ام. دولت عبد الله (دكتور):

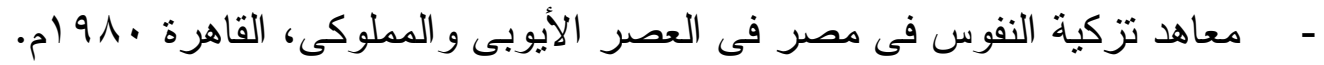

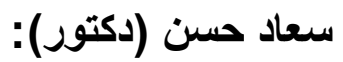

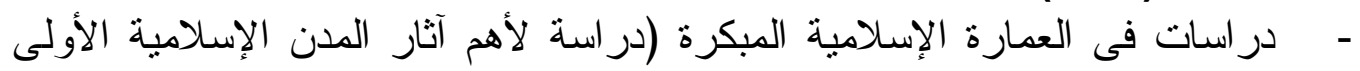

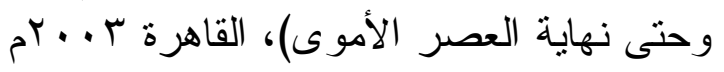




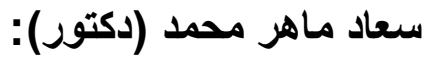

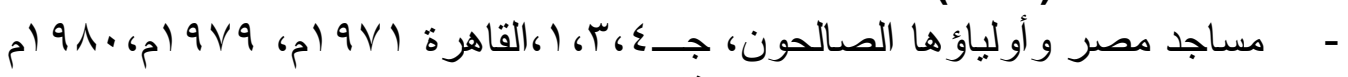
سليم عادل عبد الحق (دكتور) وخالد معاذ:

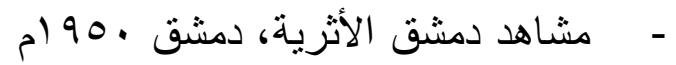

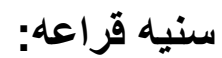

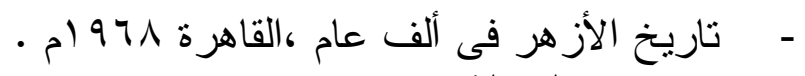

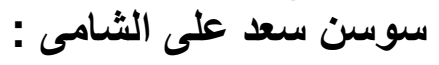

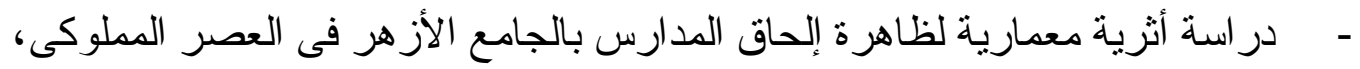

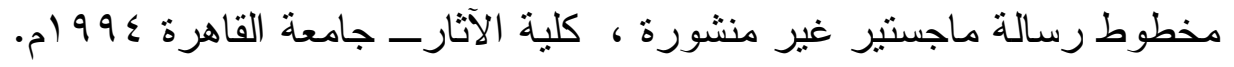
سوسن سليمان يحيى (دكتور):

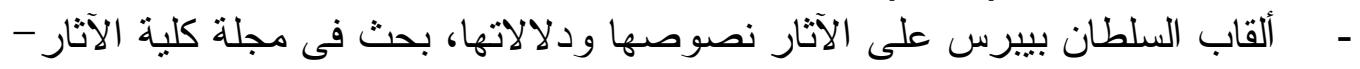

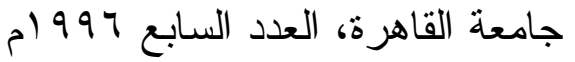

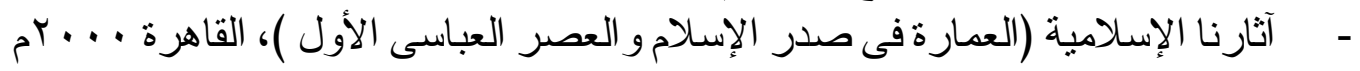
سعيد عبد الفتاح عاشور(دكتور):

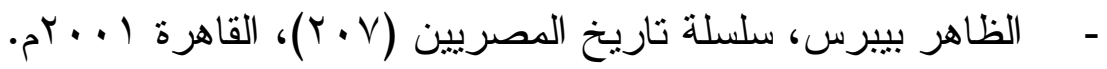
السيد عبد العزيز سالم (دكتور) وحسن عبد التون الوهاب:

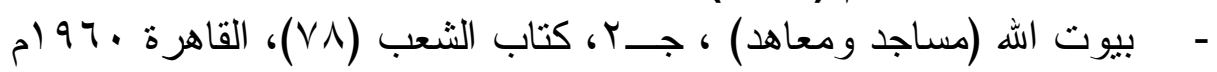

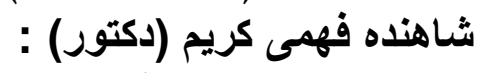

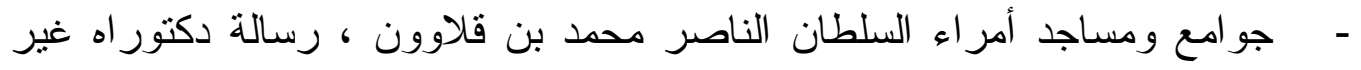

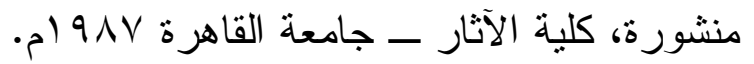

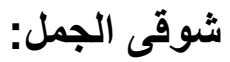

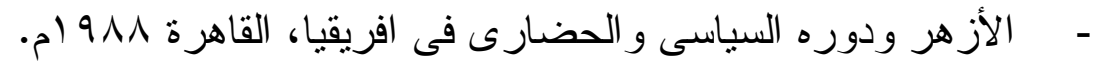
صالح لمعى (دكتور) وعبد الباقى إبراهيم ( دكتور) :

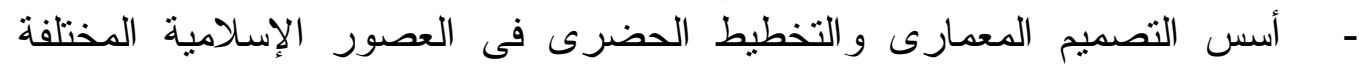

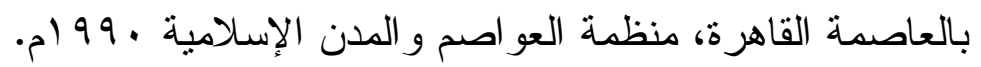
عاصم محمد رزق (دكتور):

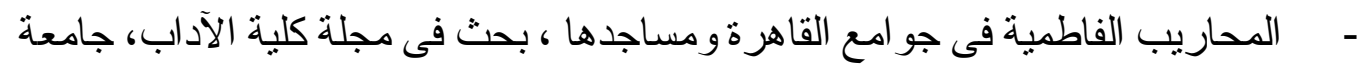

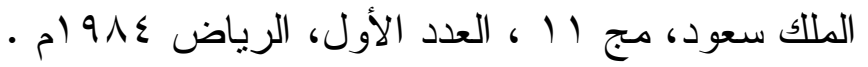

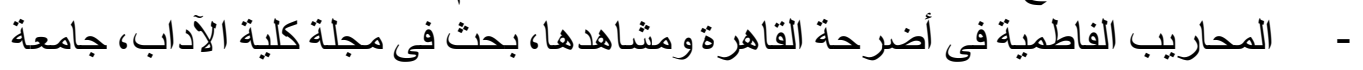

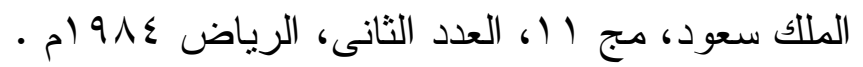


دراسات في آثار الوطن العربي ؛

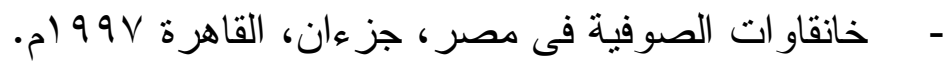

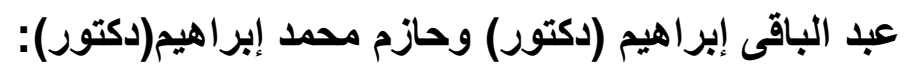

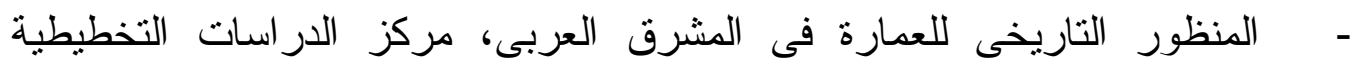

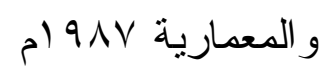
عبد الرحمن زكى (دكتور):

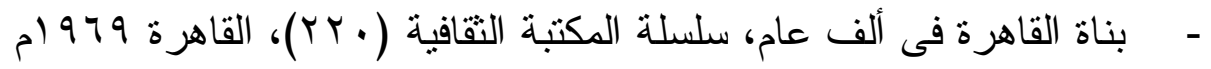

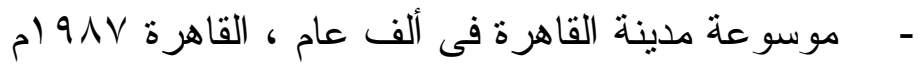
عبد الرحمن فهمى (دكتور):

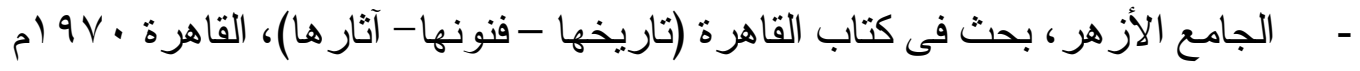

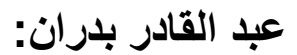

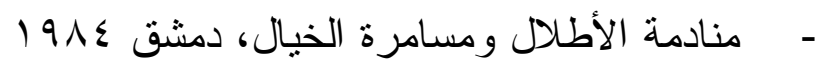
عبد القادر الريحاوى (دكتور) : - -

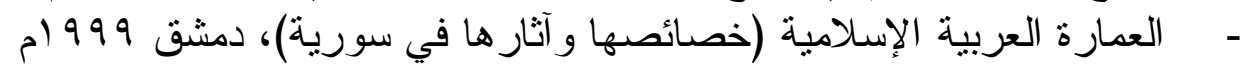

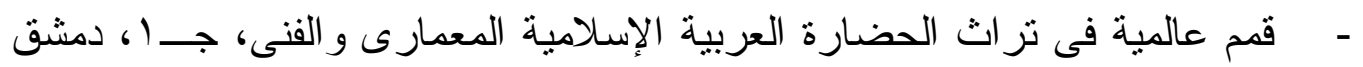
عبد الله كامل موسى (دكتور): - الأمويون و اثثار هم المعمارية (فى الثام و العر اق و الحجاز و اليمن ومصر و افريقية)،

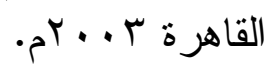
عبد الناصر ياسين (دكتور): - الفنون الزخرفية الإسلامية فى مصر منذ الفتح الإسلامى حتى نهاية العصر الفاطمى،

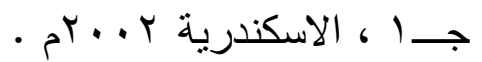

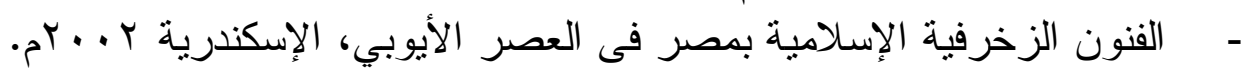
عربى كاتبى الصيادى (محمد عز الاين بن حسين):

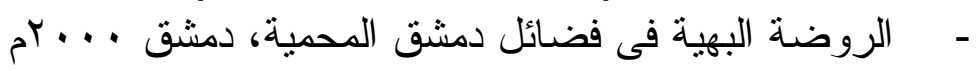

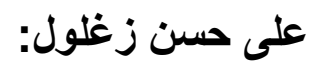
- مدرسة السلطان حسن، در اسة أثزية معمارية، مخطوط رسالة ماجستير غير منشورة، كلية الآثار - جامعة القاهرة فريا شافعى (دكتور):

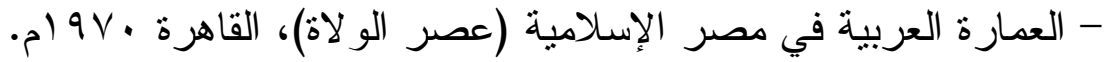




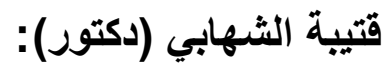

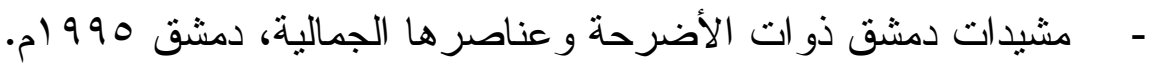
كمال الدين سامح (دكتور):

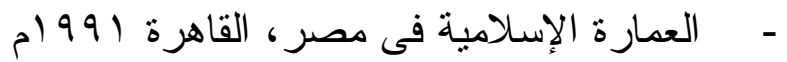
مايسه محمود داود (دكتور):

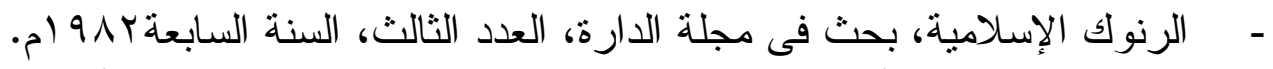

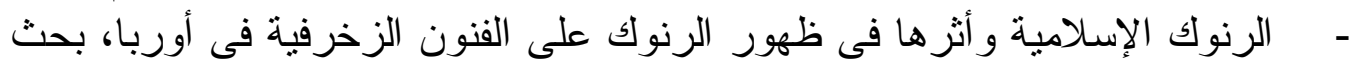

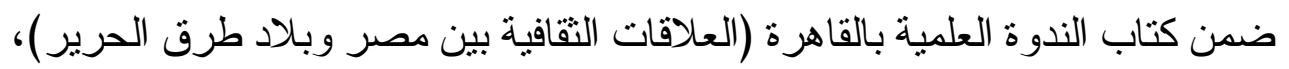

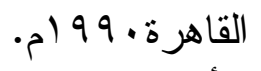

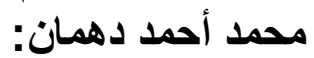

-

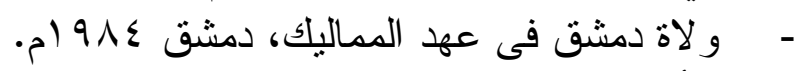

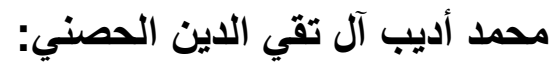

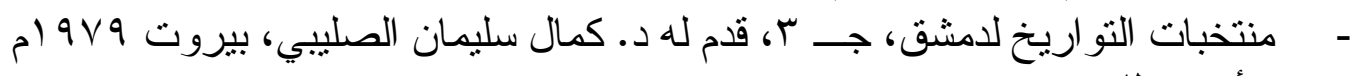

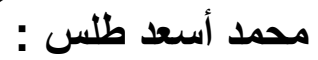

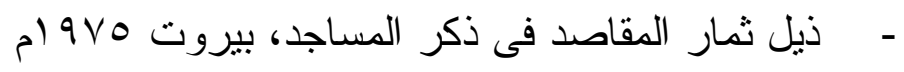

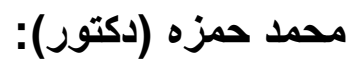

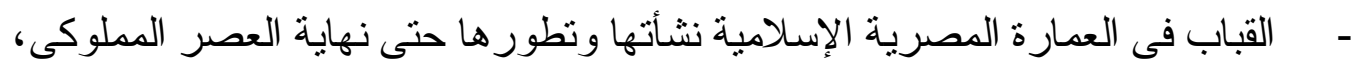
محمد عباس بلار : 99 (م. - قبة الصخرة ، بحث في كت كتاب در اسات فى الآثار الإسلامية ، المنظمة العربية للتربية

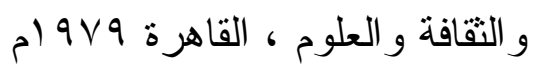
محمد عبد الستار عثمان (دكتور):

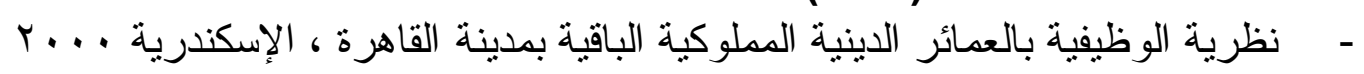

$$
\text { محمد عبد العزيز مرزوق (دكتور): }
$$

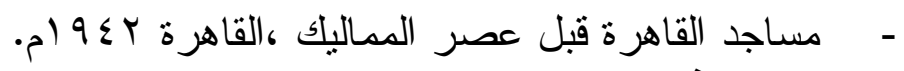
محمد كامل فارس: - محاريب حلب طرز هارئ الفنية و المعمارية، بحث فى مجلة عاديات حلب، الكتابان الر ابع

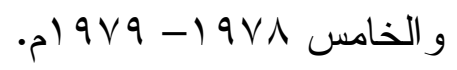


دراسات في آثار الوطن العربي ؛

$$
\text { محمد كرد على: }
$$

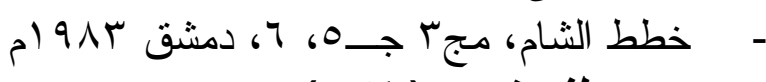

$$
\text { محمد مصطفى نجيب (دكتور): }
$$

- مدرسة الأمير كبير قرقماس وملحقاتها، مخطوط رسالة دكتور اه غير منشورة، كلية

$$
\text { الآثار - جامعة القاهرة }
$$

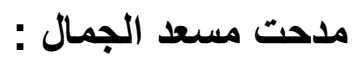

- مدرسة ومسجد الجاى اليوسفى دراسة معمارية، مخطوط رسالة ماجستير، كلية

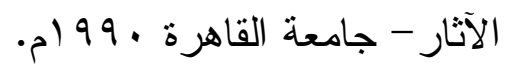

مرفت محمود عيسى(دكتور):

- مدرسة خوند بركه ( أم السلطان شعبان ) ) ، مخطوط رسالة ماجستير غير منشورة،

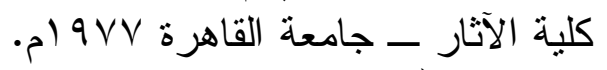

مصطفى عبد الله شيحه (دكتور):

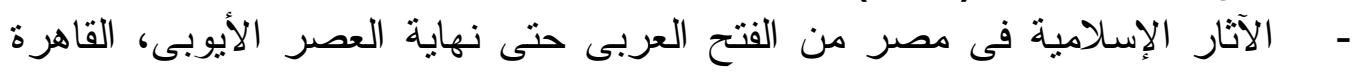

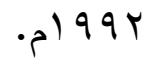

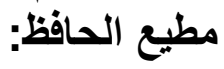

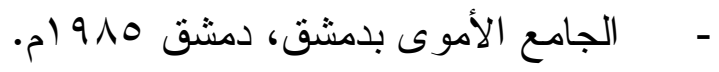
مدوح السيا حسنين: - - المشاهد الباقية بالقاهرة فى العصر الفاطمى، مخطوط رسالة ماجستير غير منشورة

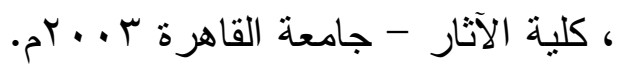

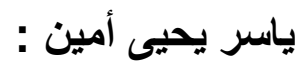
- - التحليل الإنشائي للمباني الحجرية التاريخية الإسلامية (النماذج الرقمية للحاسب الآلي

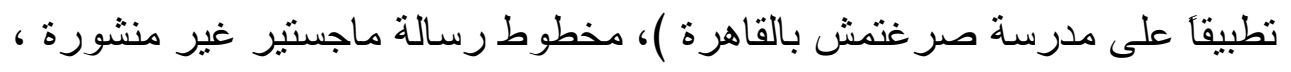

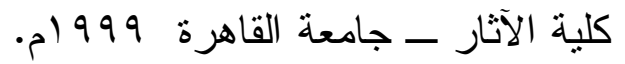
يوسف فرحات (دكتور): الأرئ

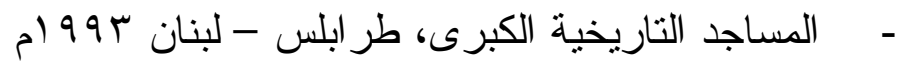


دراسات في آثار الوطن العربي ؛

\section{جانثاً: المراجع الأجنبية المعربة:}

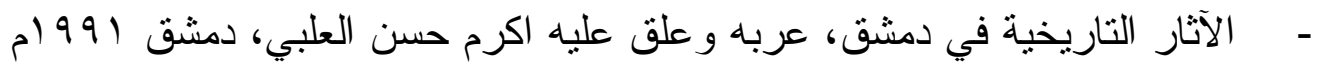
كارل ولتسينجر وكارل واتسينجر : الإن

- الآثار الإسلامية في مدينة دمشق، تعريب قاسم طوير ، تعليق د. عبد القادر الريحاوي،

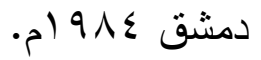

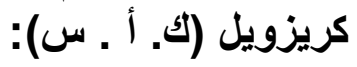

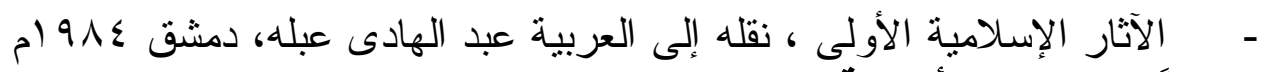

\section{Creswell (K.A.C.),}

- The Muslim architecture of Egypt,Vol.2, Ayyubids and early Bahrite Mamluks, Oxford, MCMLIX.

Grabar (O.) and Nuseibeh (S.),

- The dome of the Rock, New York, 1996.

\section{Herzfeld (E.),}

- Damascus: Studies in architecture, II, Ars Islamica, Vol. X,1942, III, Vols. XI - XII, 1946.

\section{Petrsen (A.),}

- Dictionary of Islamic architecture, London - New York,1996.

\section{Rivoire (G.T.),}

- Moslem architecture, its origins and development, London, 191.

\section{Richmond (E.Th.),}

- The dome of the rock in Jerusalem a description of its Structure and decoration, Oxford, 1924

\section{Saifuddin (J.S.),}

- AL- Aqmar (a living Testimony To the Fatemiyeen), 
دراسات في آثار الوطن العربي ؛

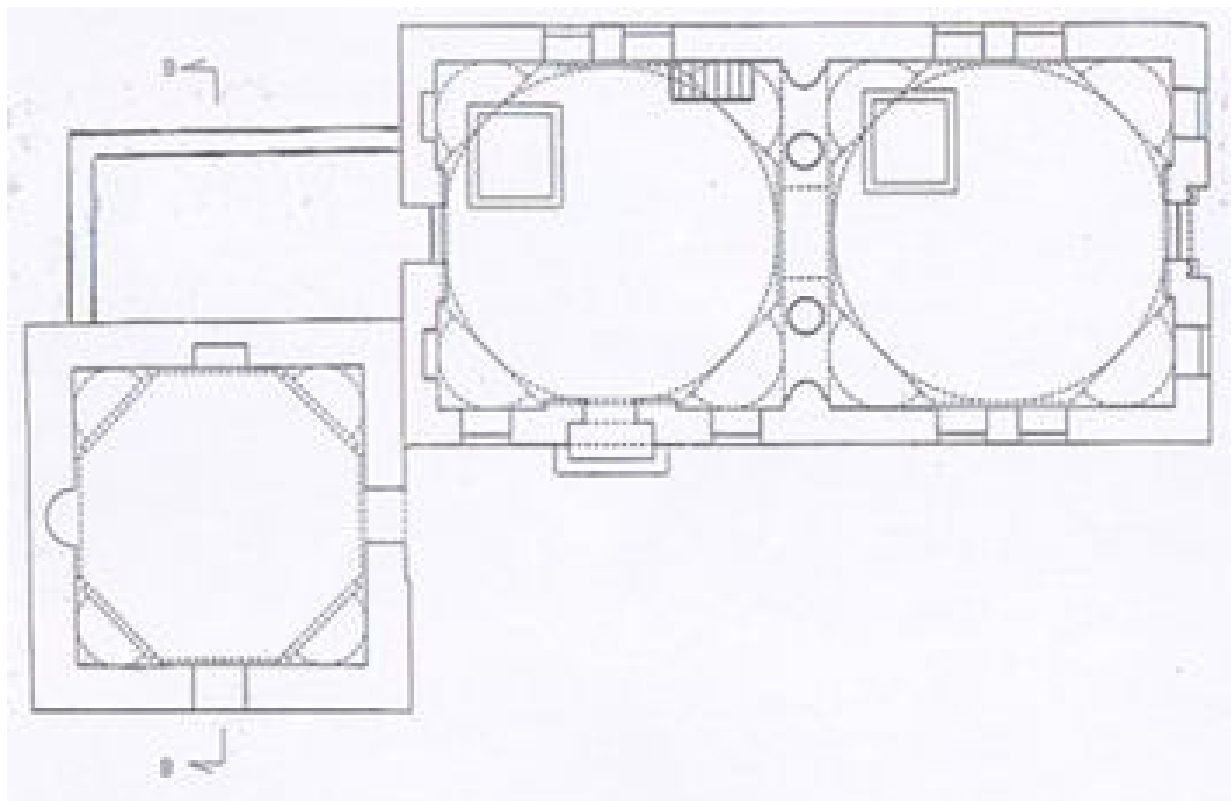

(نكل ( ) القبة الظاهرية: المسقط الأفقى ويظهر به القبة إلى اليسار ومقام كل من

السيدتين سكينة وأم كلثوم إلى اليمين.

تتفيذ المهندس جهاد تغلبى

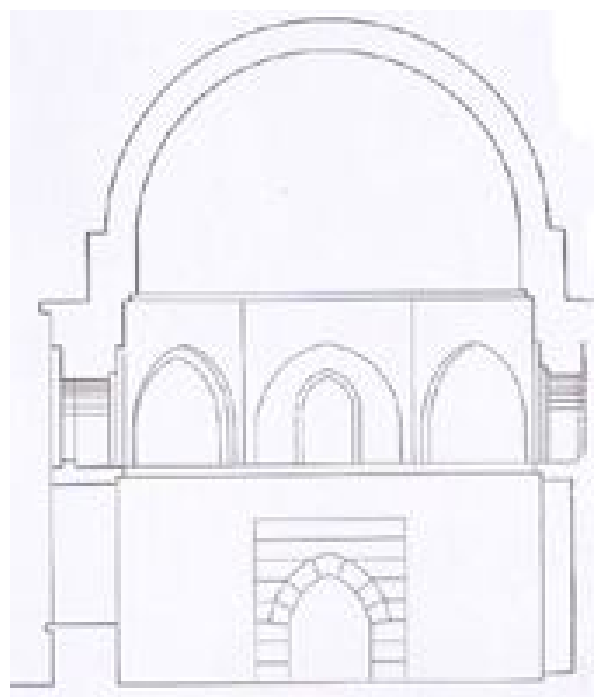

(شكل r) القبة الظاهرية:مقطع يظهر به الجدار الجنوبى.

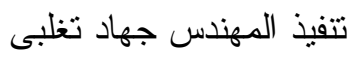

$$
1.70
$$




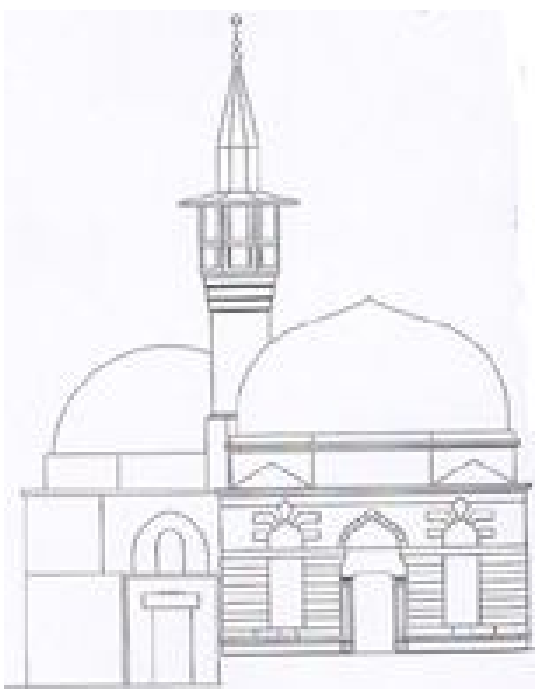

(نككلr) القبة الظاهرية: الو اجهة الثمالية للقبة إلى اليسار و الو اجهة الثمالية لمقام كل من السيدتين سكينة وأم كلثوم إلى البمين. تتفيذ المهنس جهاد تغلبى

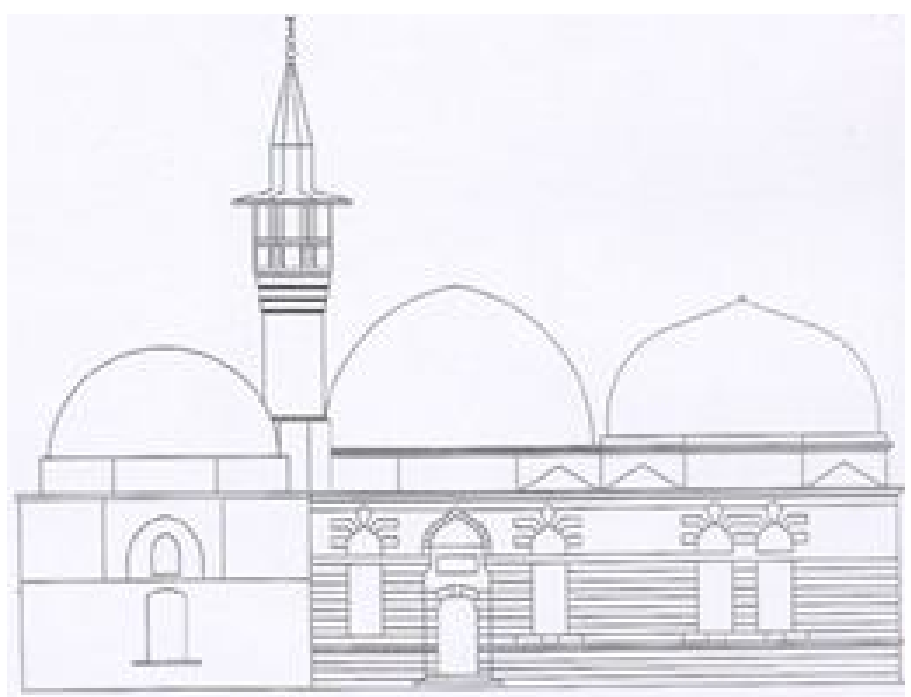

(ثكل ؛ ) القبة الظاهرية: الو اجهة الثرقية للقبة إلى اليسار و الو اجهة الشرقية لمقام كل من السيدتين سكينة و أم كلثوم إلى اليمين. تتفيذ المهنس جهاد تغلبى 


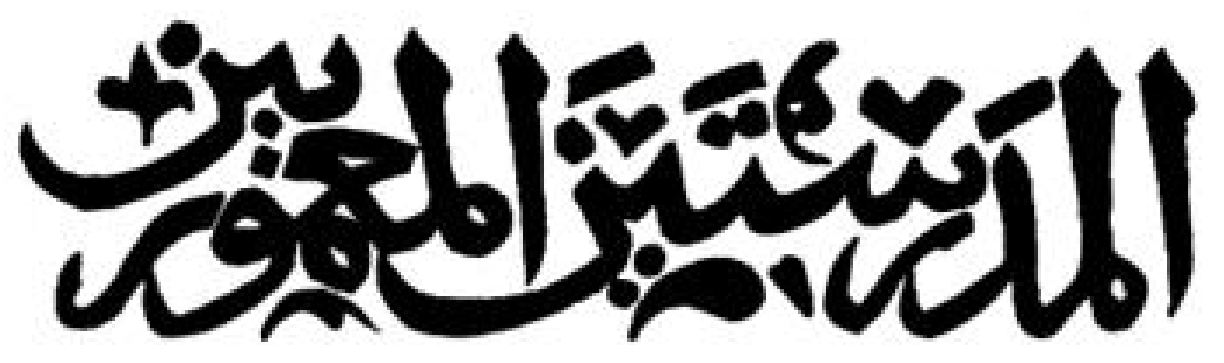
(شكله) التربة و المدرستان الظاهرية: جزءء من النص التأسيسى المسجل على حجر المدخل الرئيسى . من عمل الباحث: الث

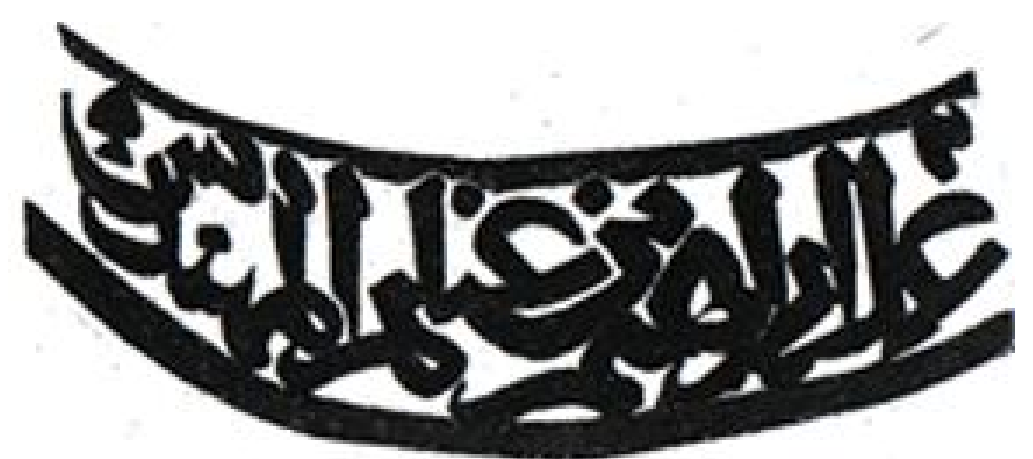

(شكل) التزبة و المدرستان الظاهرية: اسم المهندس مسجل بصيغة" عمل إبر اهيم بن

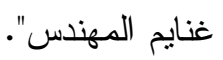
من عمل الباحث: 


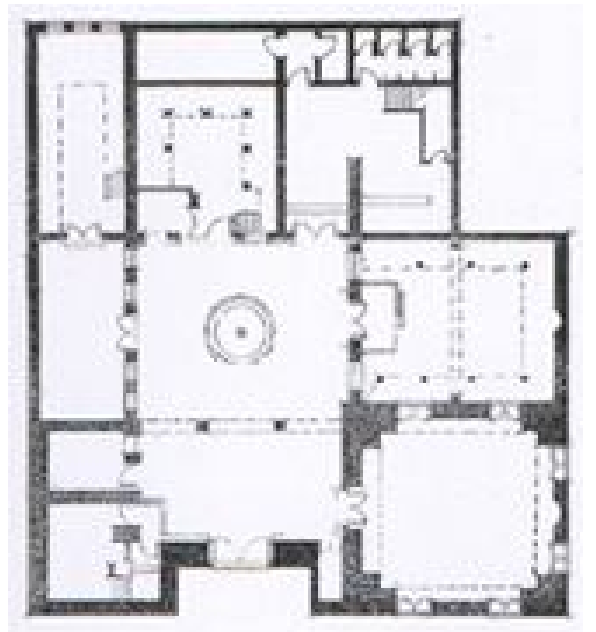

(شكلVV) التربة و المدرستان الظاهرية: المسقط الأفقى الأول .

نقلا عن: المديرية العامة للآثار و المتاحف السورية الألفورية.

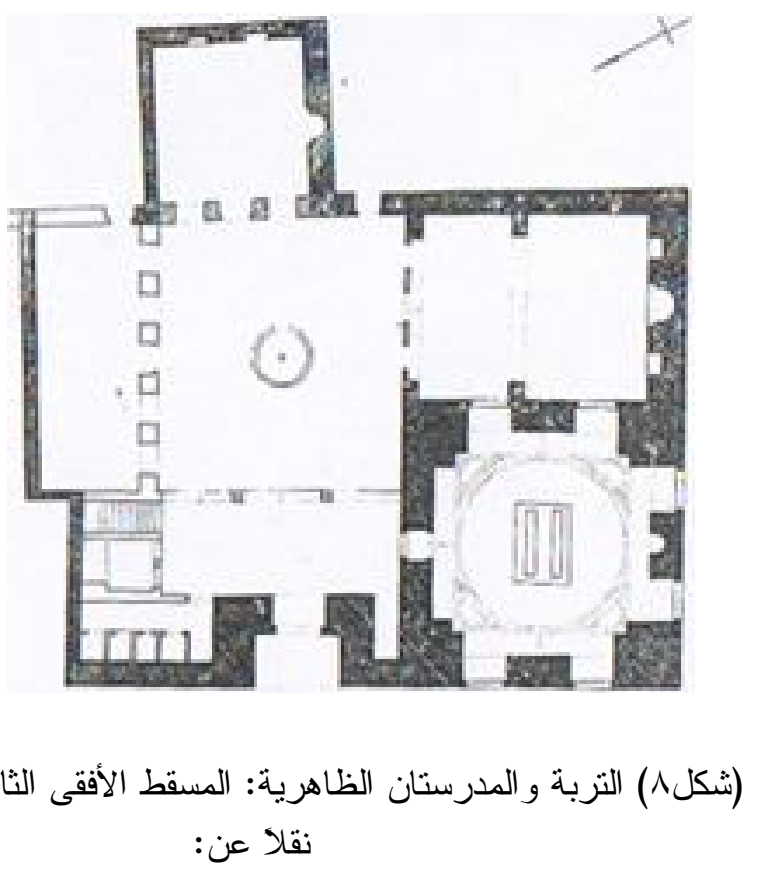

Meinecke (M.),Die Mamlukische architektur in Agypten und Syrien, (648/1250 Bis 923/1517), Gluckstadt 1992, Teil.1, p.38,Abb.11. 
دراسات في آثار الوطن العربي ؛

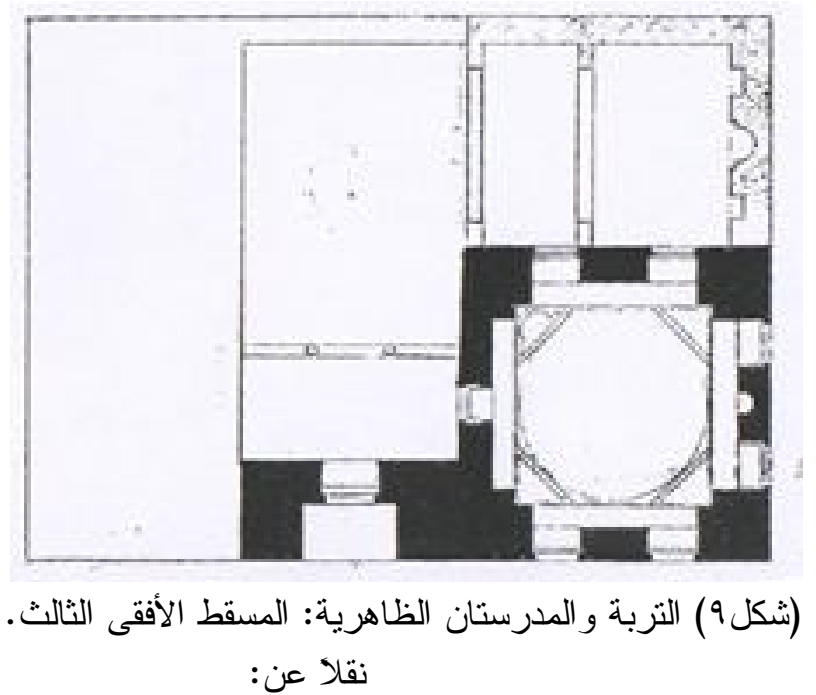

Herzfeld (E.),Damascus: Studies in architecture III, Ars Islamica, Vols. XI- XII, 1946, Fig. 108.

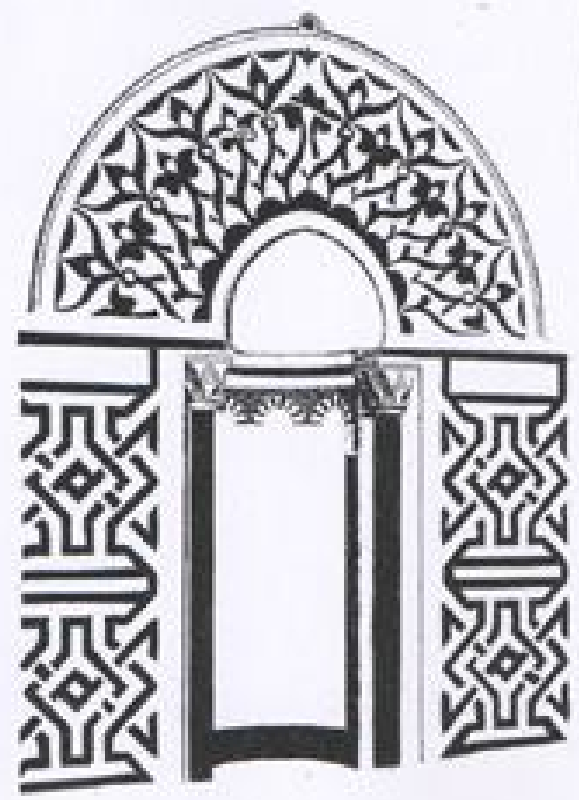

(شكل • () النربة و المدرستان الظاهرية: محر اب التربة من عمل الباحث 
دراسات في آثار الوطن العربي ؛

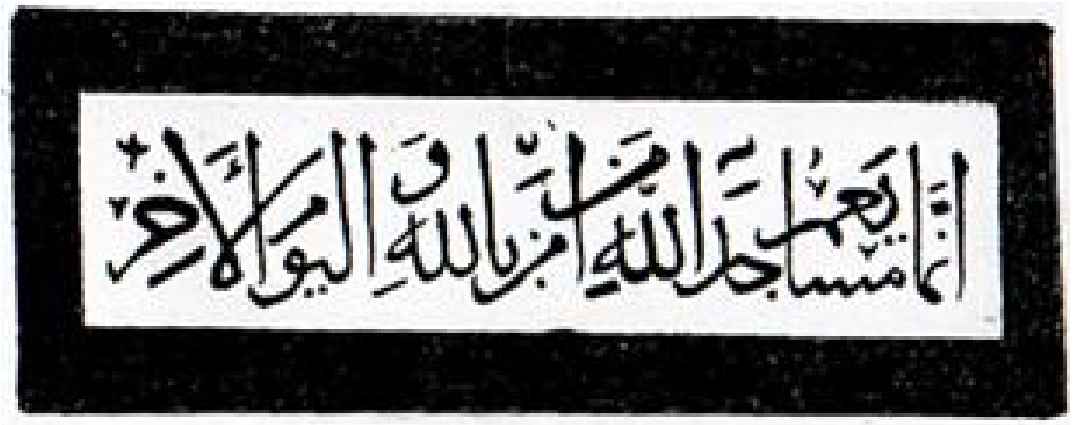

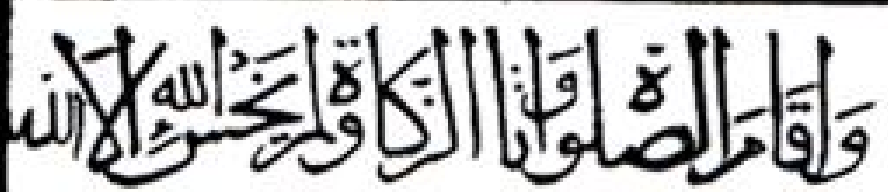

(ثكل (1) التزبة و المدرستان الظاهرية: النص الكتابى القر آنى المسجل على جانبى محر اب التزبة.

من عمل الباحث

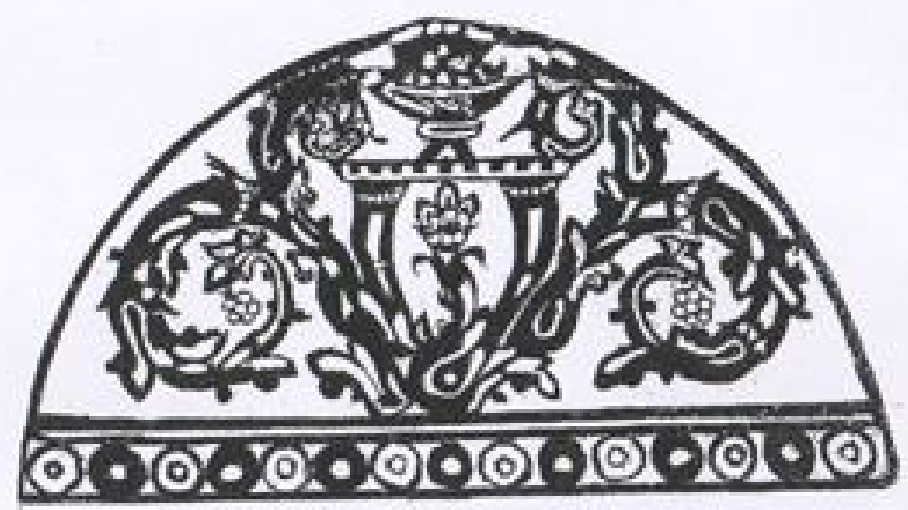

(ثكل r ( ) التربة و الددرستان الظاهرية: زخارف نباتية بالفسيفساء فوق إحدى فتحات

النو افذ المستطيلة الموجودة بالتربة.

من عمل الباحث 


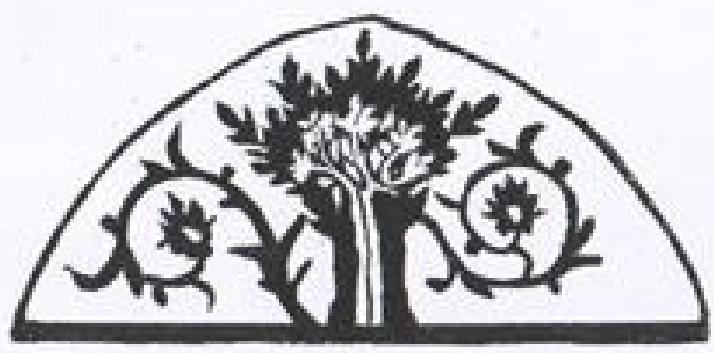

(شكل ( ) التزبة و المدرستان الظاهرية: زخارف نباتية بالفسيفساء فوق إحدى فتحات

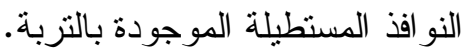
من عمل الباحث

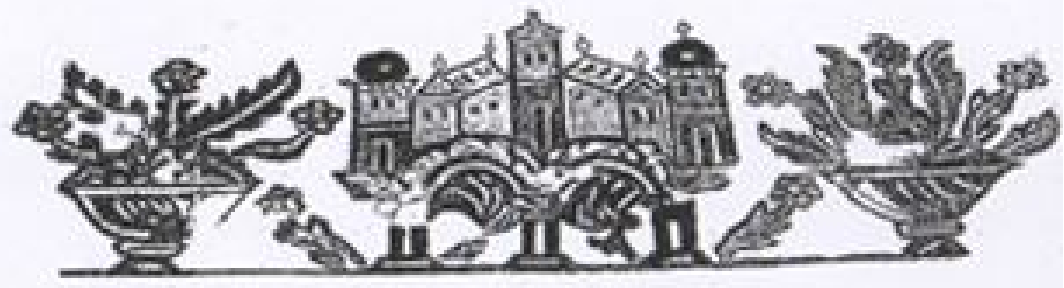

(شكل ع ا) التربة و المدرستان الظاهرية: أثكال مز هريات وزخارف نباتية ورسوم عمائر بالفسيفساء على الجدار الغربى للتربة. من عمل الباحث

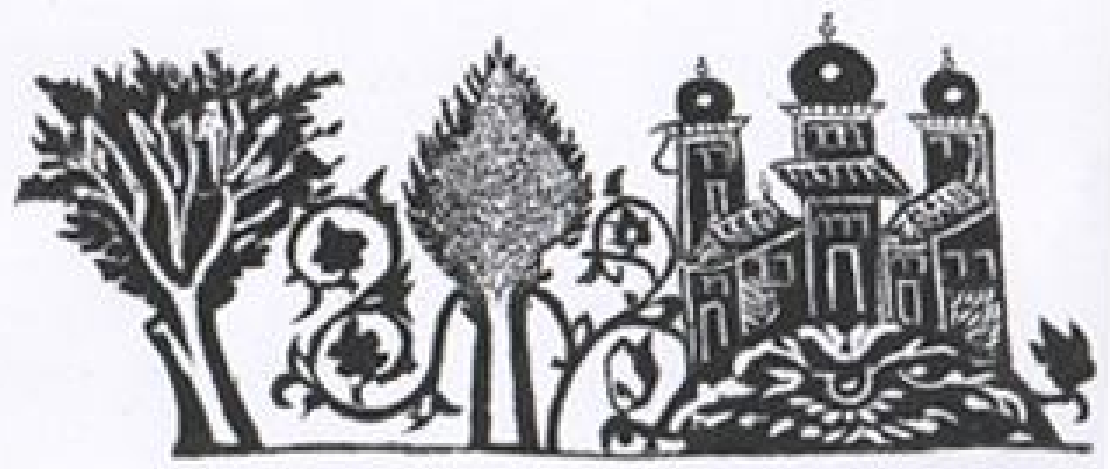

(شكل 1 ) التربة و المدرستان الظاهرية: رسوم أشجار و عمائر بالفسيفساء على الجدار الثمالى للتربة.

من عمل الباحث: 
دراسات في آثار الوطن العربي ؛

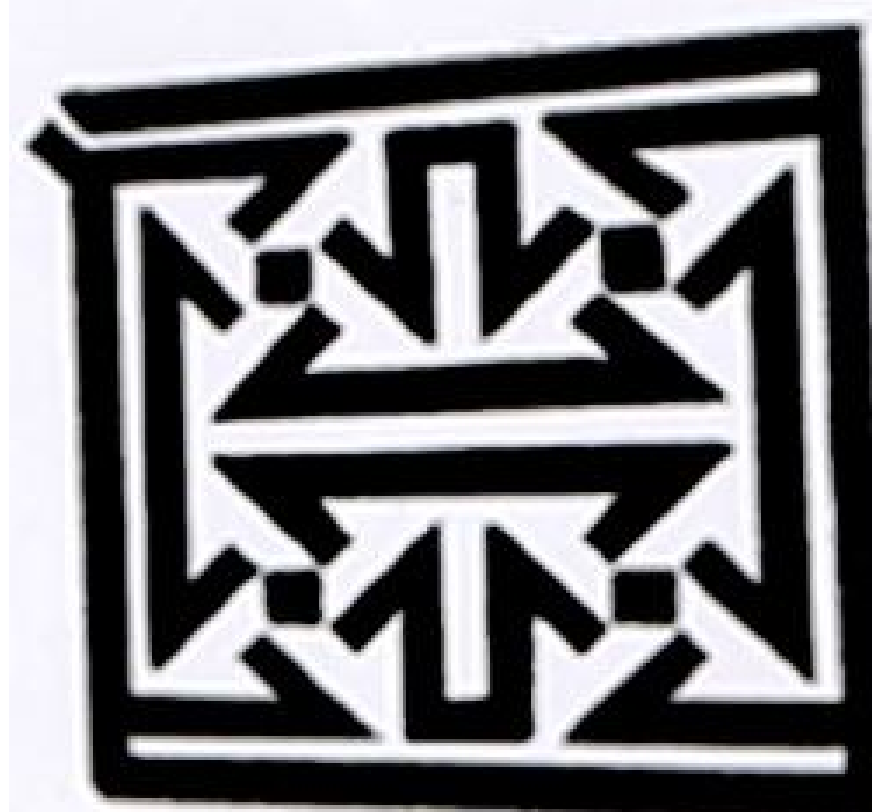

(شكل1 1 ) التربة و المدرستان الظاهرية: زخارف هندسية بالرخام على الجدار الشمالى للتربة.

من عمل الباحث 
دراسات في آثار الوطن العربي ؛
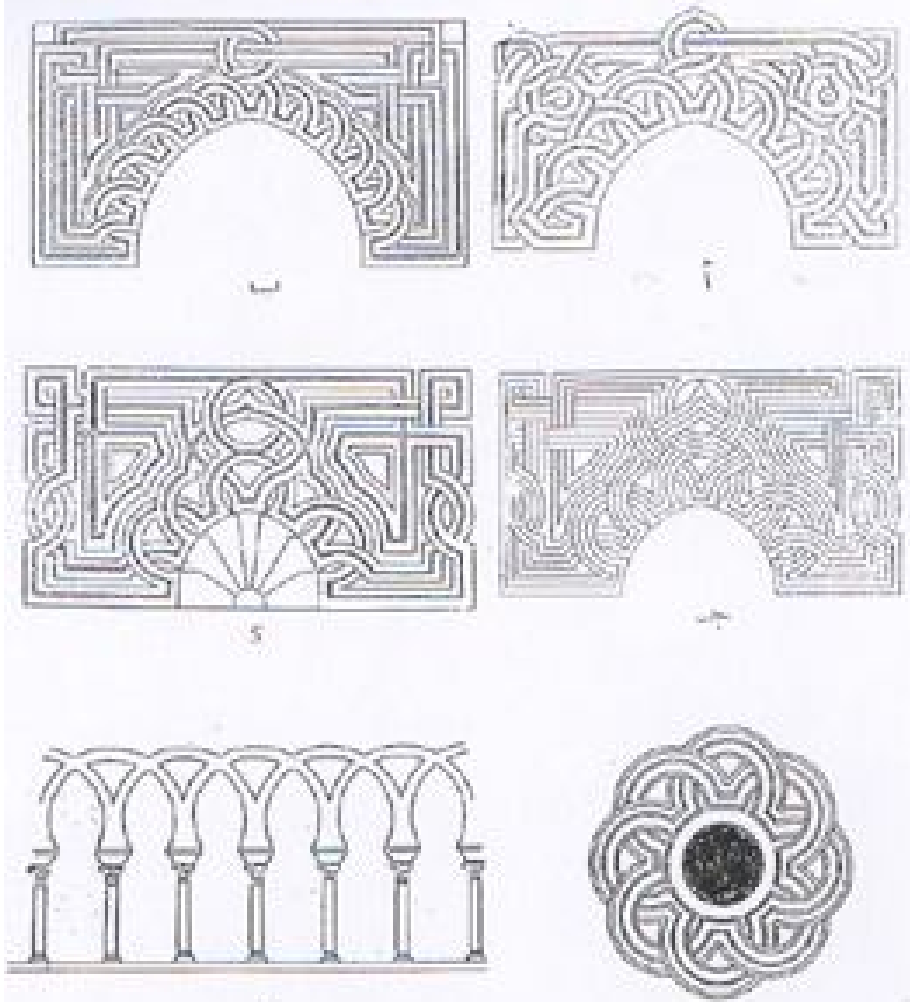

$y$

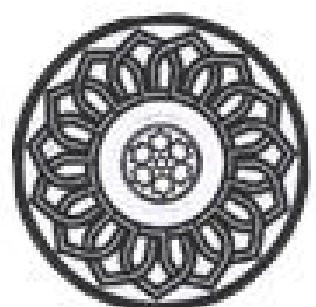

(شكل V أ- ز ) زخرفة العقود المثقاطعة:

ب- المدرسة السلطانية بحلب جــــ مدرسة الفردوس بحلب

أ- المدرسة الثاذبختية

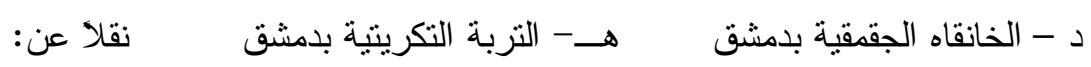

Herzfeld (E.),OP.Cit., II, Vol. X, 1942, Fig.83, III, vols. XI XII, Fig.60.

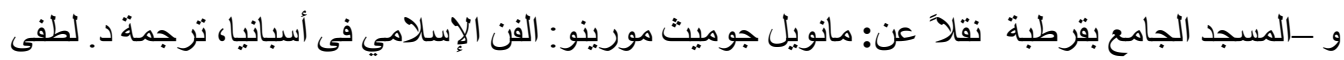

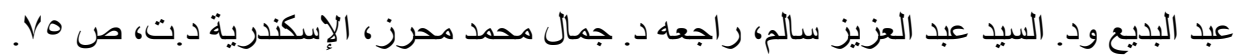

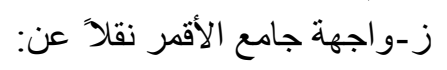

Saifuddin (J.S.), AL. Aqmar (a living Testimony To the Fatemiyeen), London, 2000, P.46. 


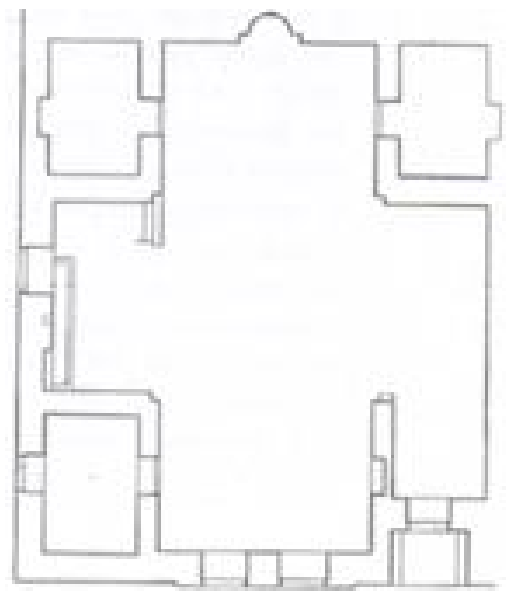

(شكلم1/) المدرسة التتكزية: المسقط الأفقى.

نقلا عن:المديرية العامة للآثار و المتاحف السورية السفية.

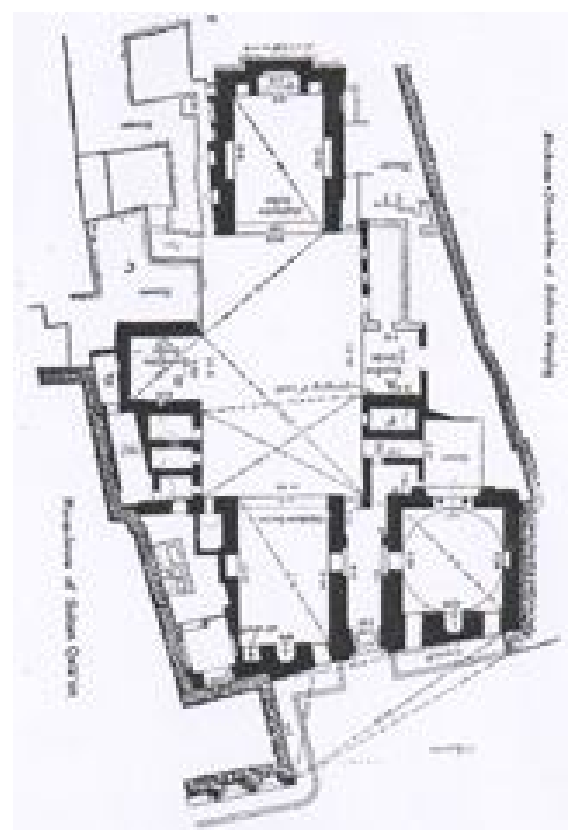

(شكل9 1 () مدرسة الناصر محمد بن قلاوون: المسقط الأفقى.

$$
\text { نقلا عن: تمند }
$$

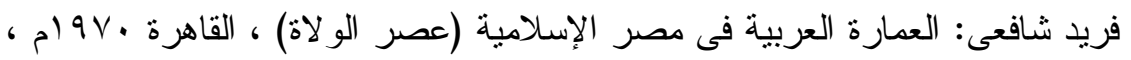

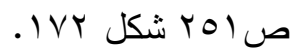


دراسات في آثار الوطن العربي ؛

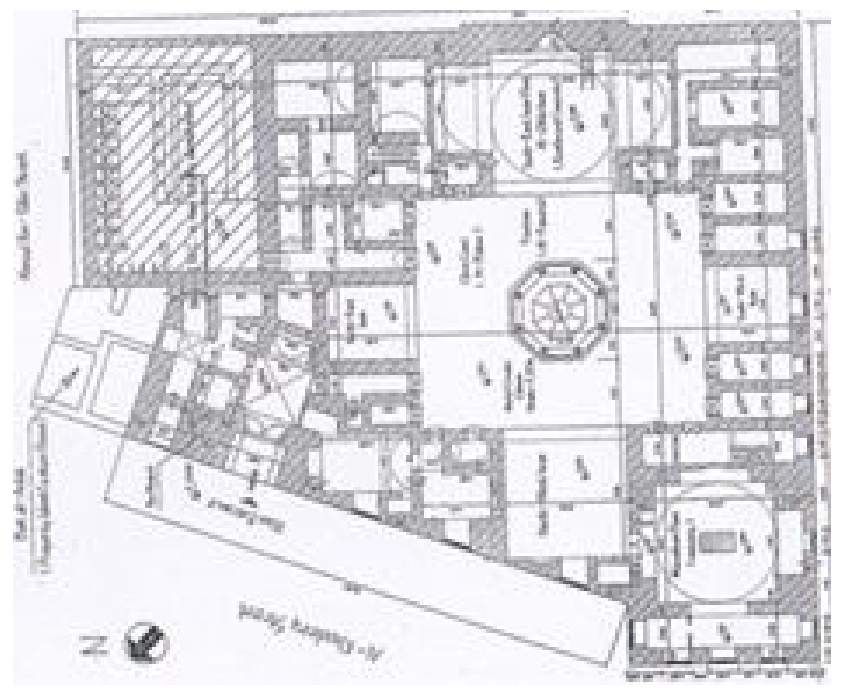

(شكل • r) مدرسة صر غتمش: المسقط الأفقى.

نقلا عن : ياسر يحيى: التحليل الإنشائى للمبانى الحجرية التاريخية الإسلامية (النماذج الرقية الإفية للحاسب

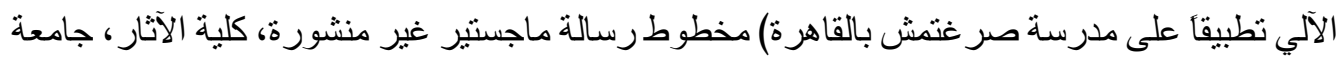

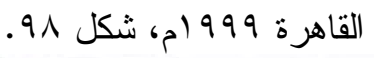

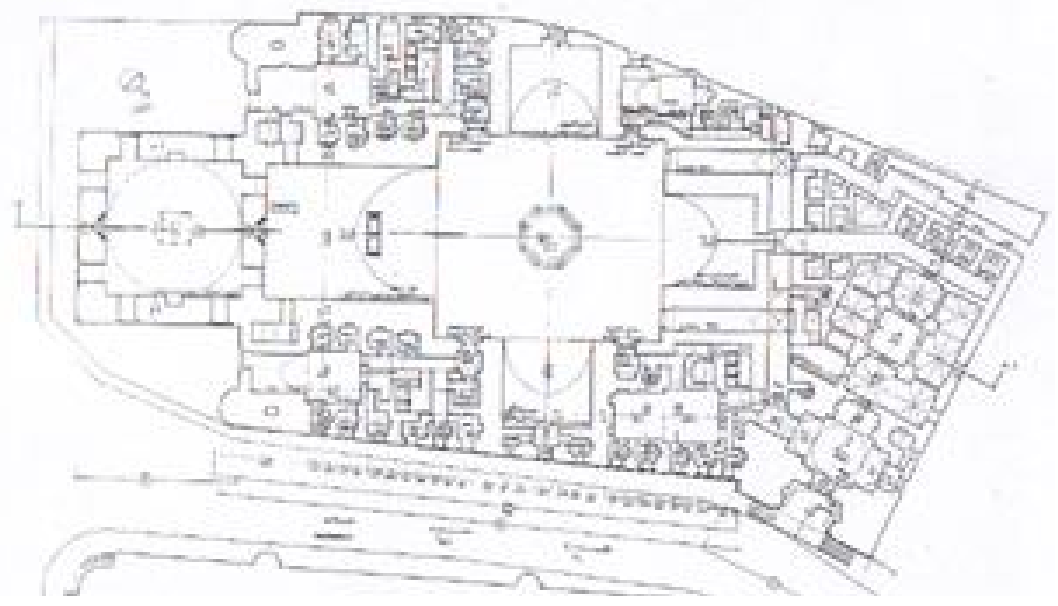

(شكل (Y) مدرسة السلطان حسن: المسقط الأفقى.

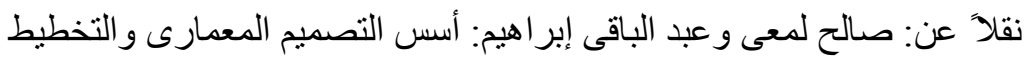

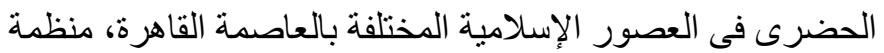

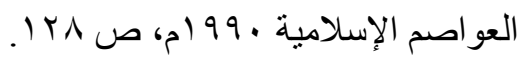




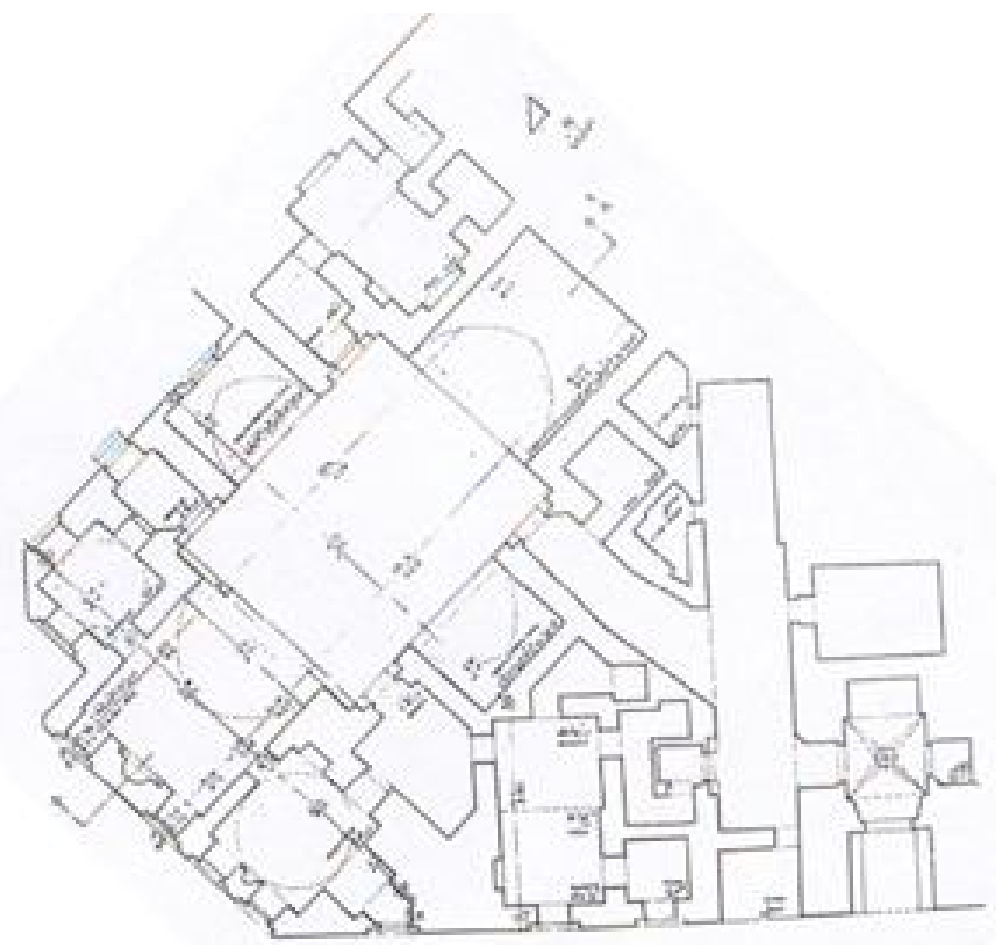

(شكل r r مدرسة أم السلطان شعبان: المسقط الأفقى.

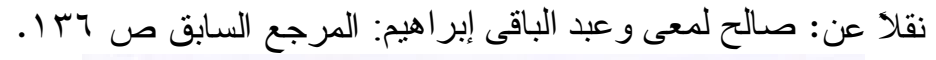

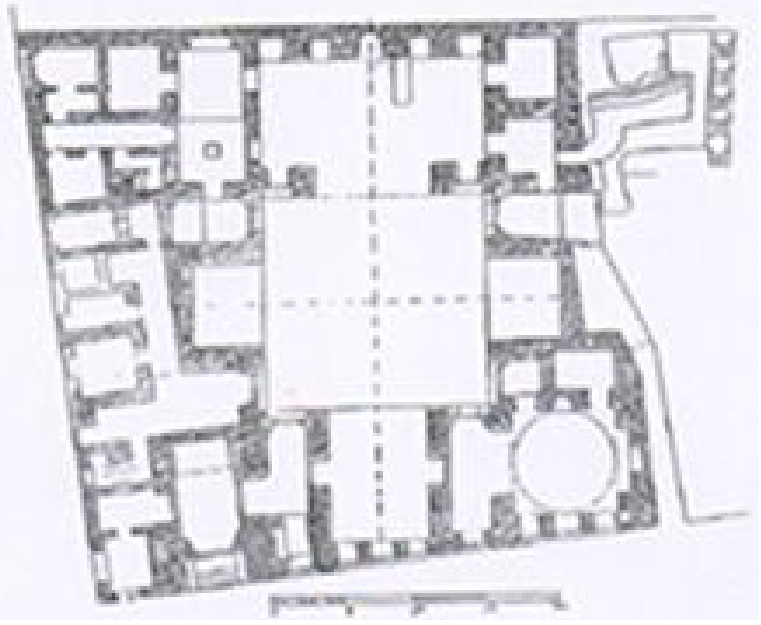

(شكل r ( مدرسة الجاى اليوسفى: المسقط الأفقى.

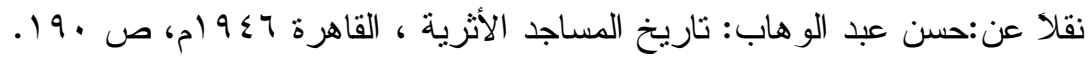


دراسات في آثار الوطن العربي ؛
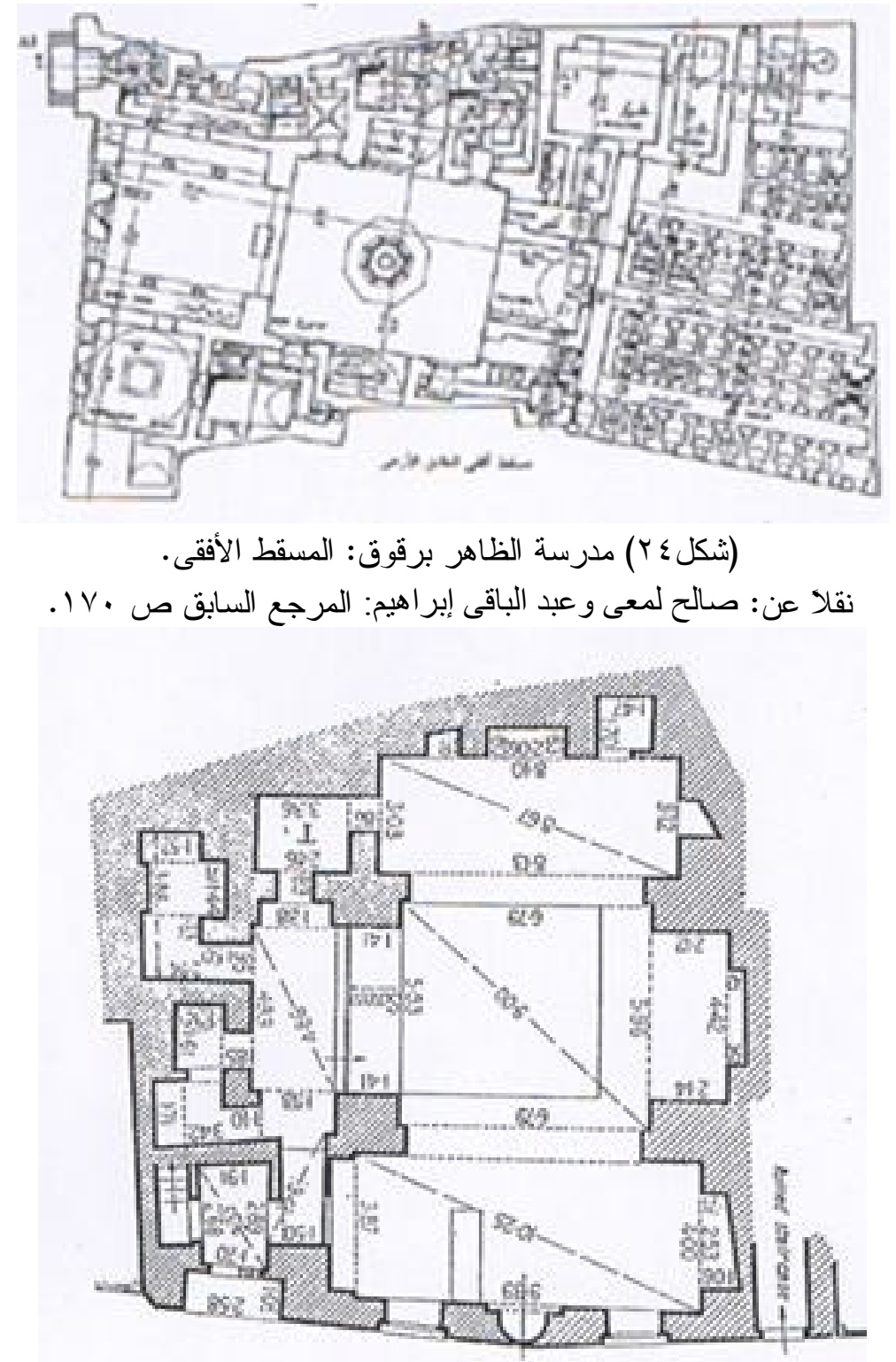

$$
\text { (شكل \% r مسجد آل ملك الجوكندار : المسقط الأفقى. نقل عن: }
$$

Creswell (K.A.C.), The Muslim architecture of Egypt,Vol.2, Ayyubids and early Bahrite Mamluks, Oxford, MCMLIX, P.271,fig.149. 
دراسات في آثار الوطن العربي ؛

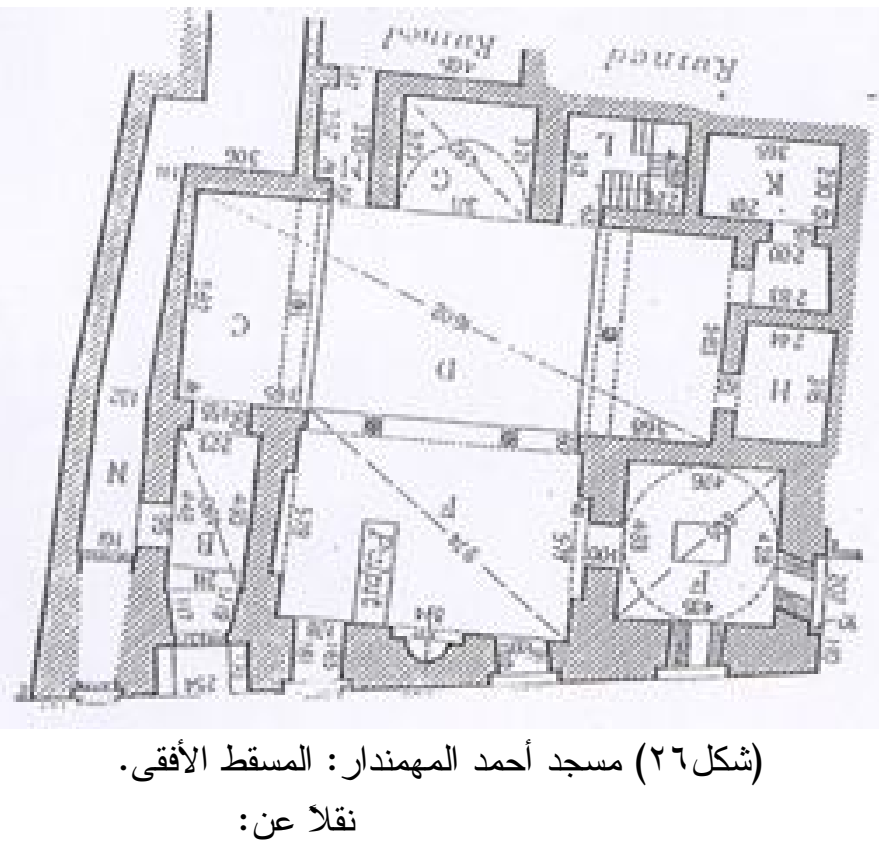

Creswell (K.A.C.), Ibid., Vol.2, p.274, fig. 150.

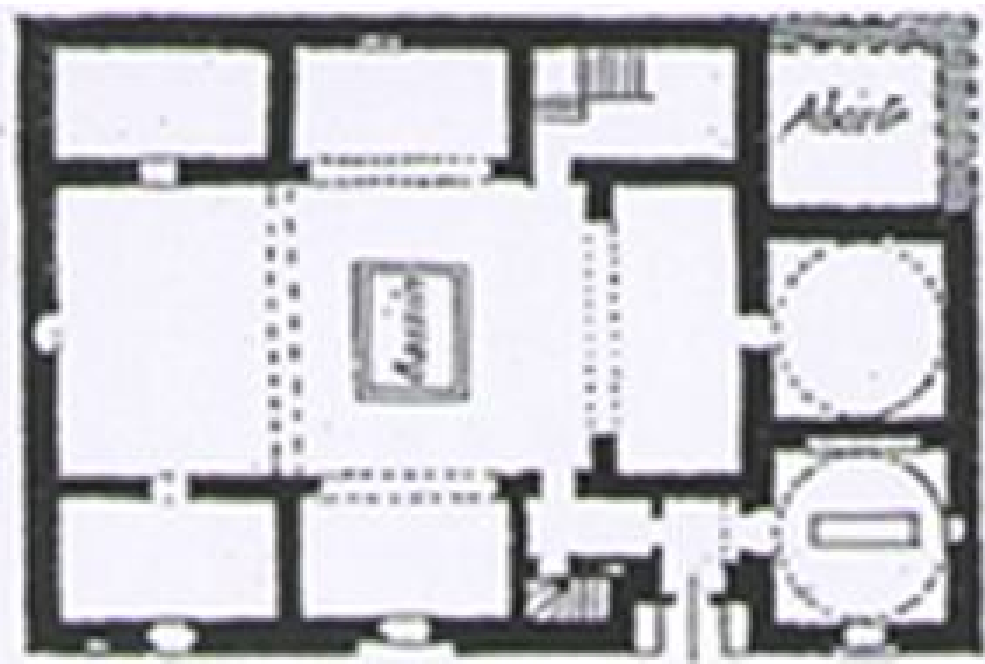

(شكلrVI المدرسة الأفريدونية: المسقط الأفقى الأول.

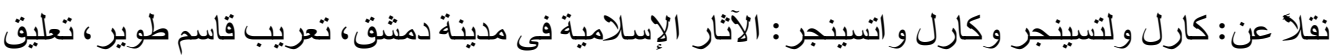

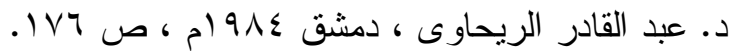




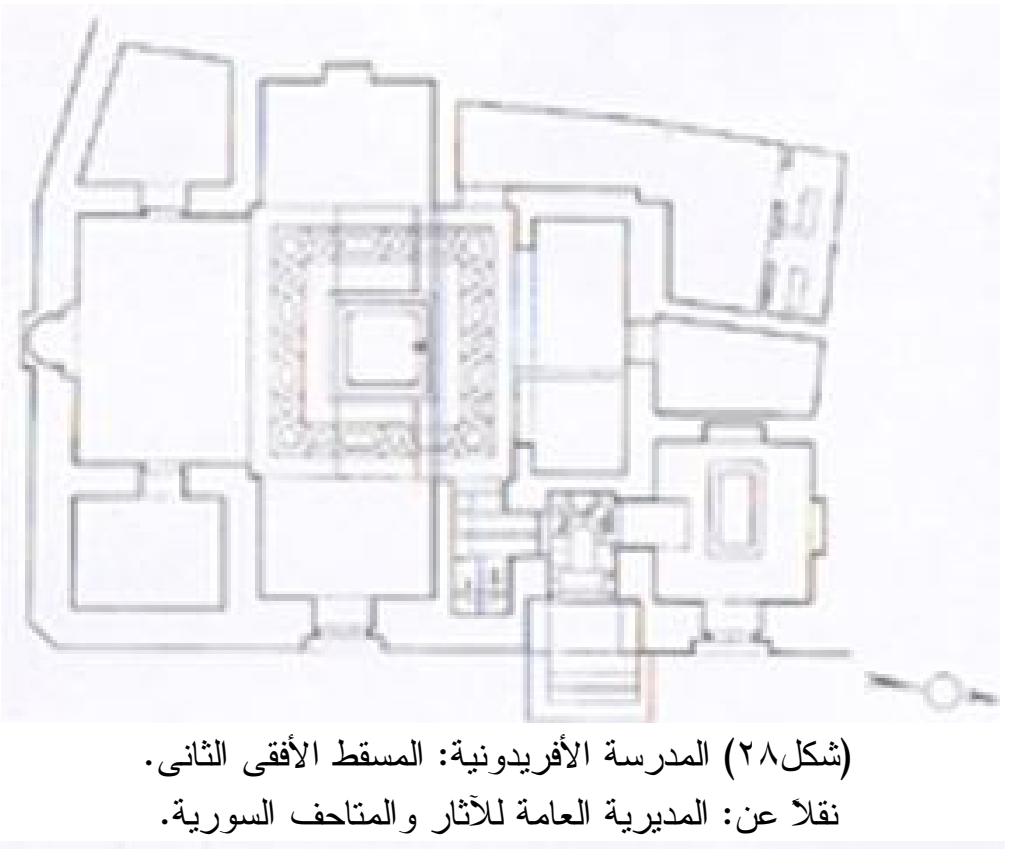

نقلا عن: المديرية العامة للآثار و المتاحف المبة السورية.

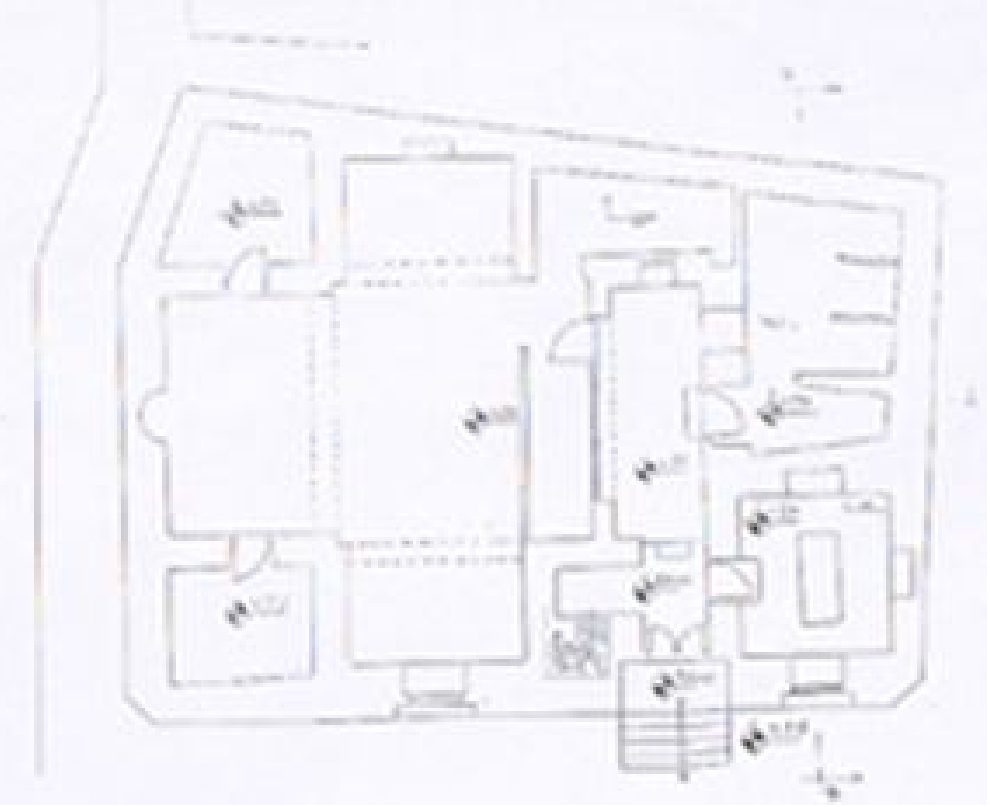

(شكل ج ) المدرسة الأفريدونية: المسقط الأفقى الثالث.

نقلا عن: المديرية العامة للآثار و المتاحف السورية السورية. 


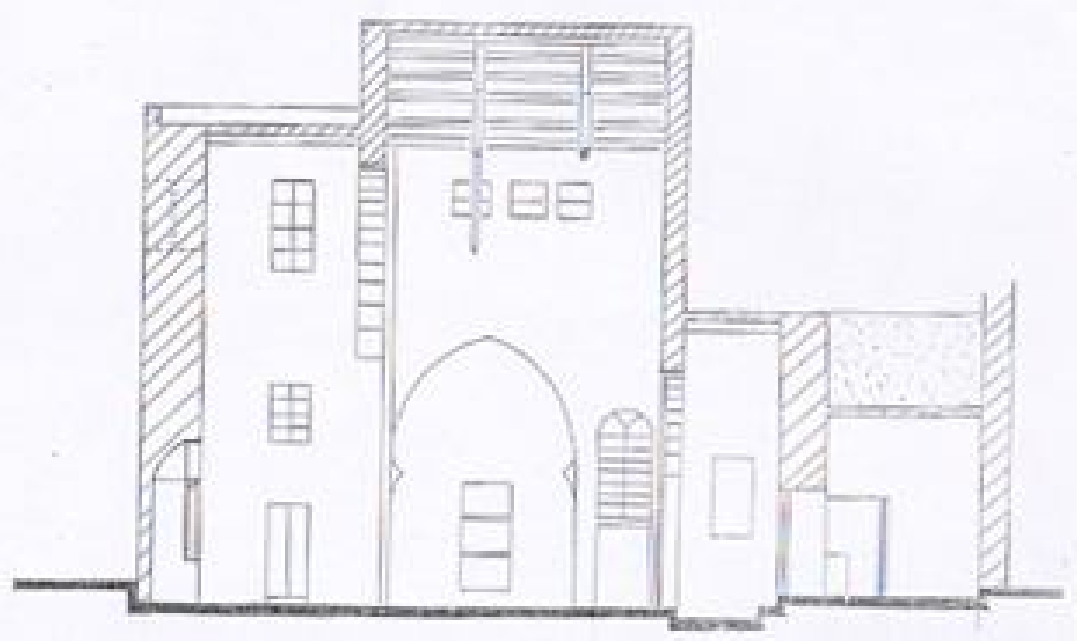

(شكل • r) المدرسة الأفريدونية: مقطع شمال - جنوب يُظهر الجهة الغربية.

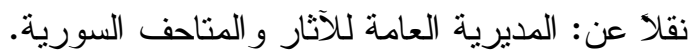

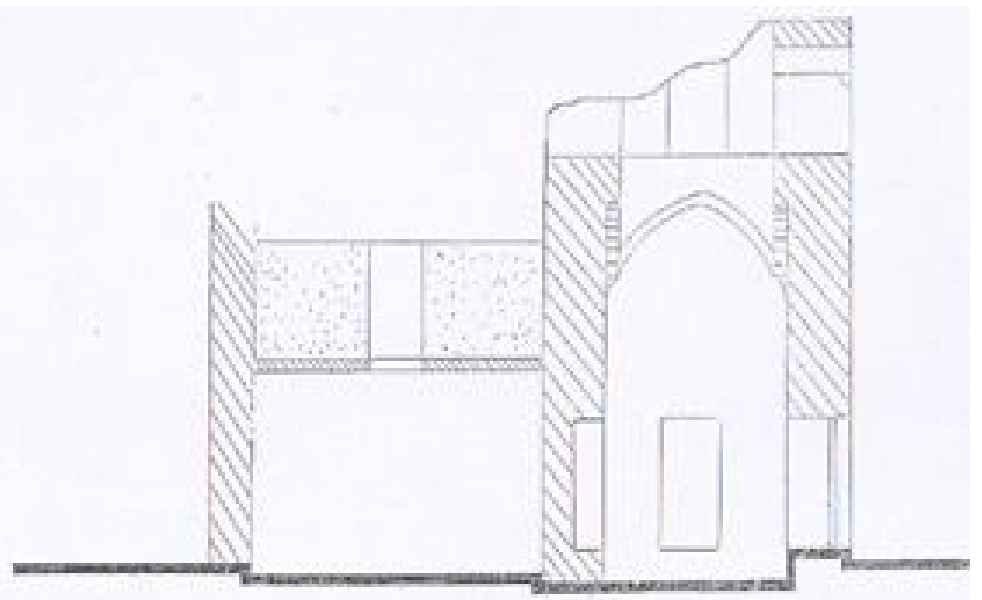

(شكل (ب) المدرسة الأفريدونية: مقطع شرق - غرب يُظهر الجدار الثمالى للتربة

نقلا عن: المديرية العامة للآثار و المتاحف السورية. 
دراسات في آثار الوطن العربي ؛

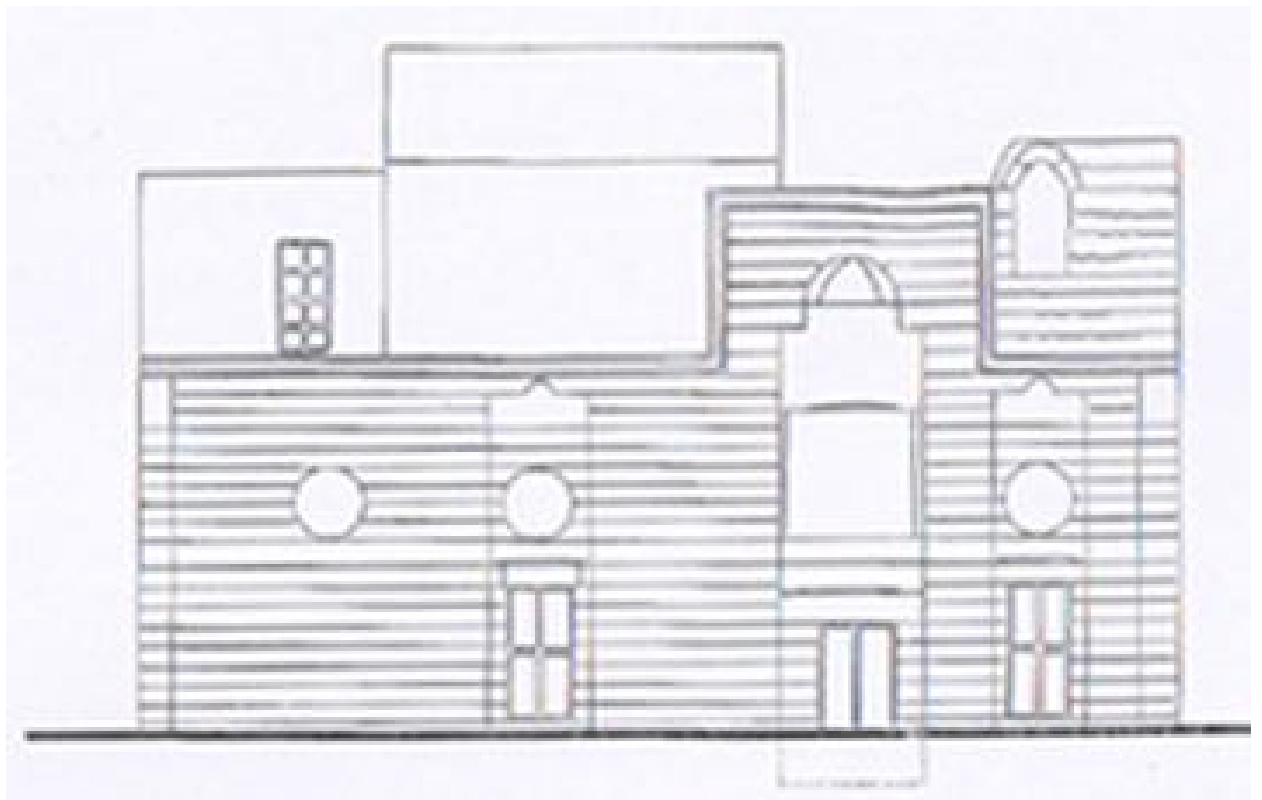

(ثكل rr) الددرسة الأفريدونية: الواجهة الثرقية الرئيسية.

نقلا عن: الدديرية العامة للآثار و المتاحف السورية. 
دراسات في آثار الوطن العربي ؛
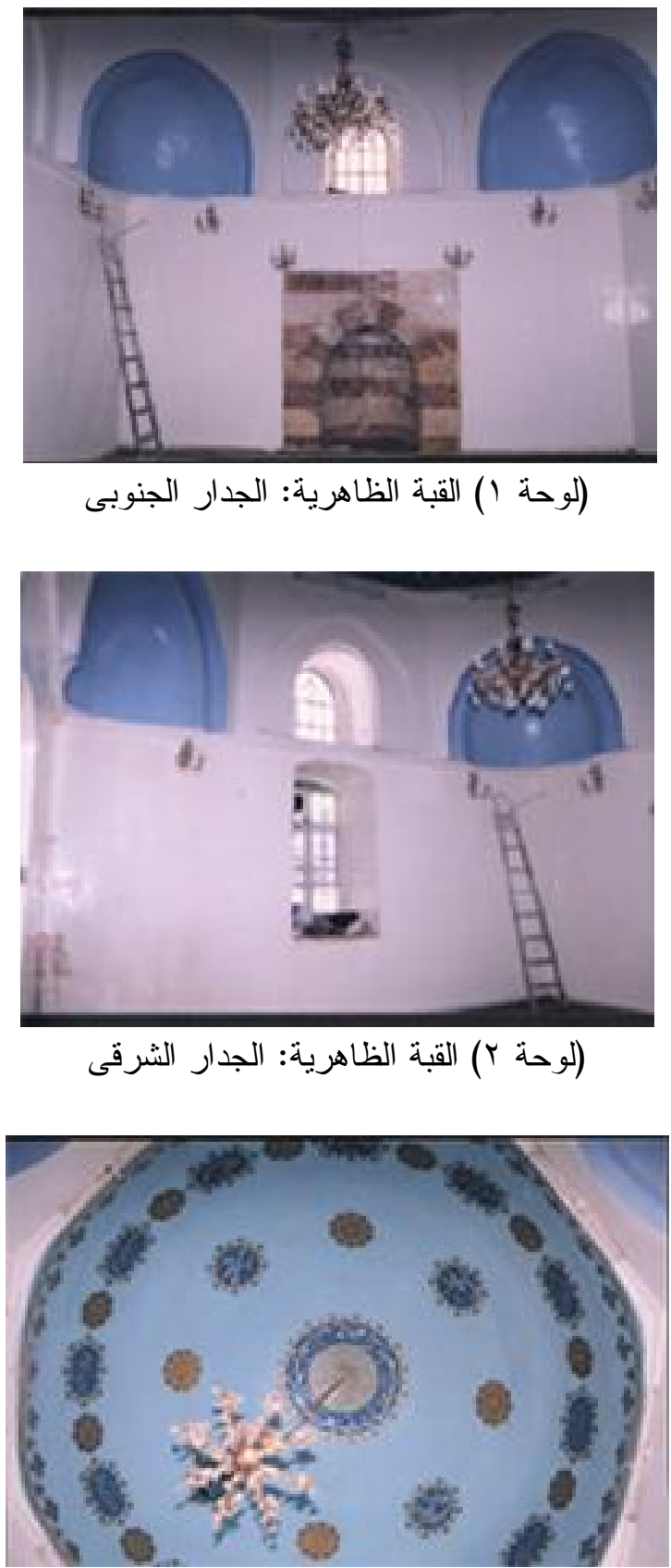

(لوحة r) القبة الظاهرية: باطن القبة 
دراسات في آثار الوطن العربي ؛

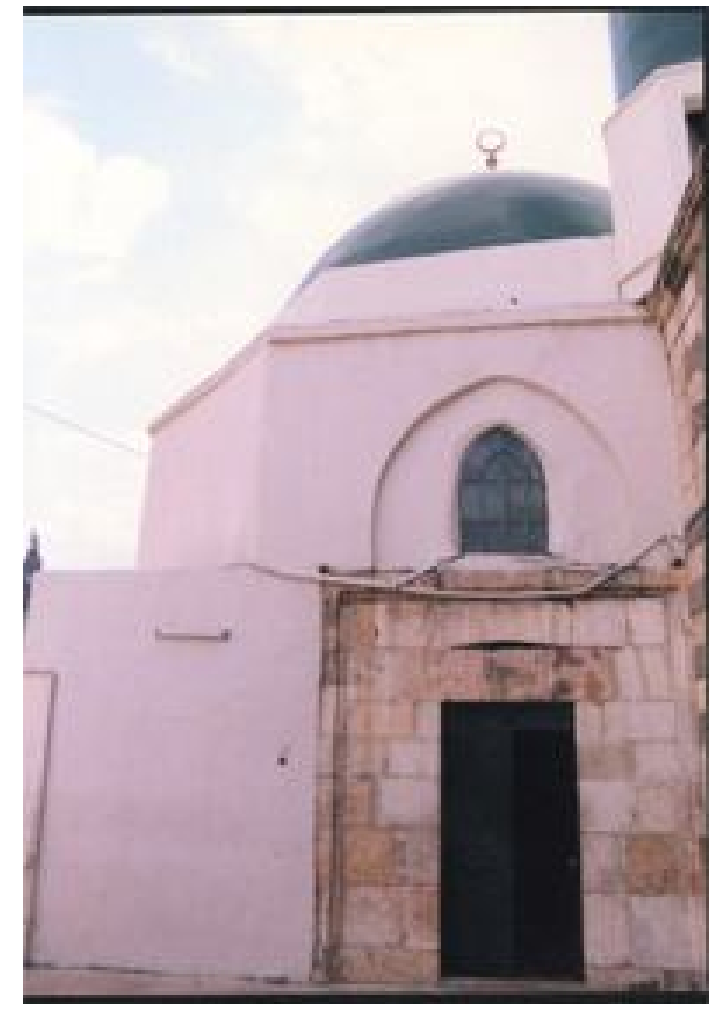

(لوحة ع) القبة الظاهرية: الو اجهة الثمالية الرئيسية

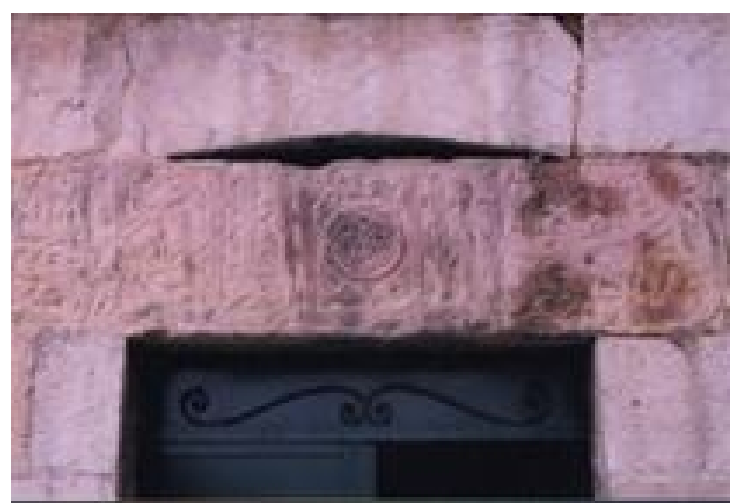

(لوحة ه) القبة الظاهرية: الساكف (العتب) الذى يعلو فتحة باب الدخول بالو اجهة

الثمالية الرئيسية. 


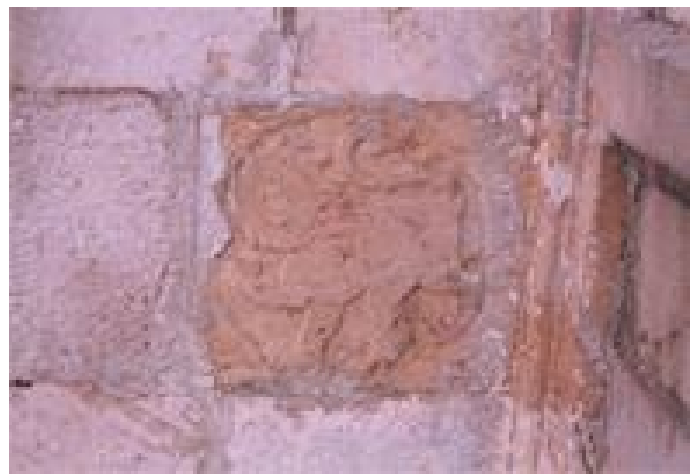

(لوحة 7$)$ الدخول ويوجد بالجانب الآخر الشرقى رنك آخر مماثل مو اجه له.

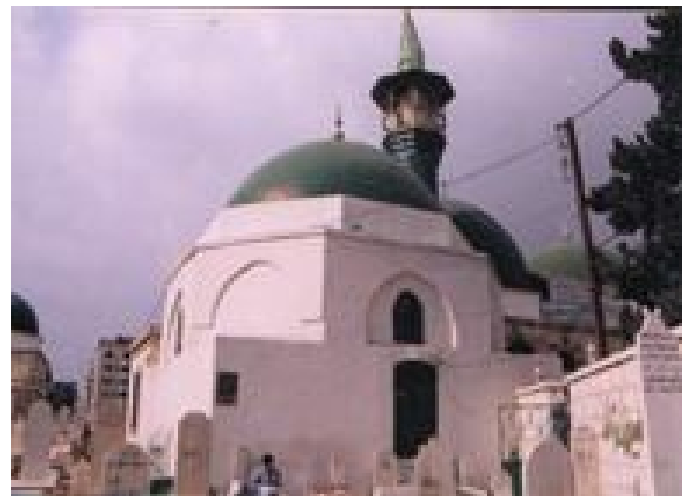

(لوحة V) القبة الظاهرية: الو اجهتان الثرقية بصدر الصورة والجنوبية إلى اليسار.

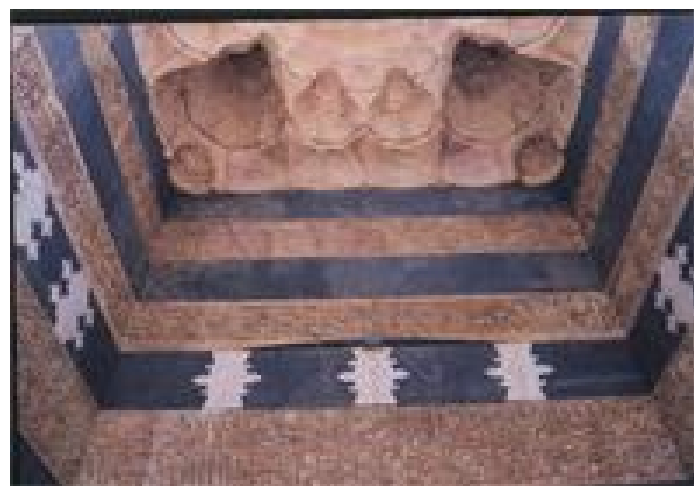

(لوحة ^) التربة و المدرستان الظاهرية: النصوص الكتابية المسجلة بحجر المدخل الرئيسى. 


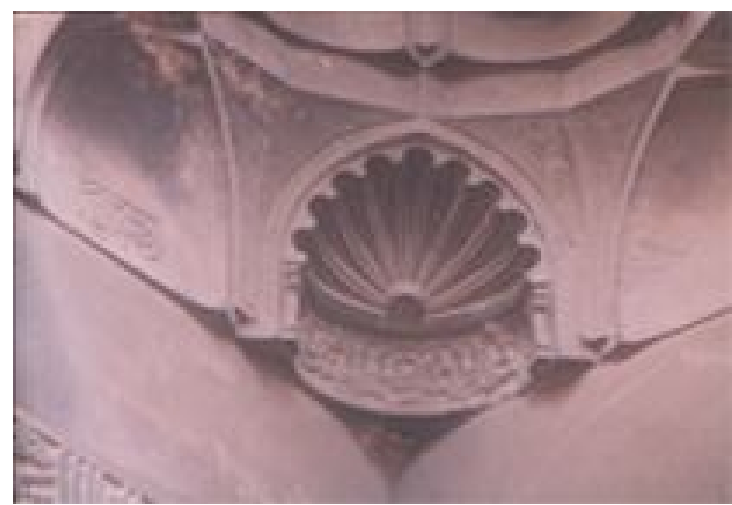

(لوحة 9) التربة و الددرستان الظاهرية: أسم المهنس المسجل بالقسم السفلى من الهن

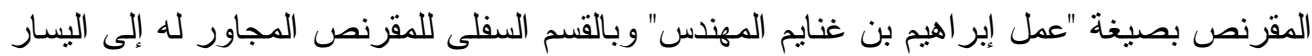
التكملة بالدعاء "رحمه الله".

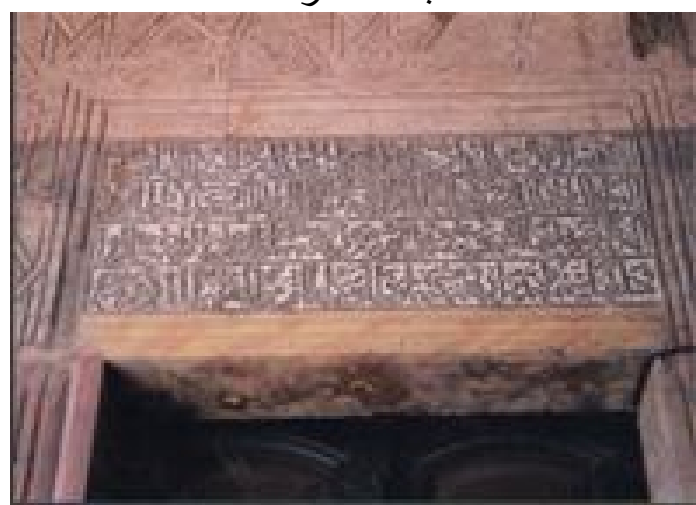

(لوحة ( ) التربة و المدرستان الظاهرية: نص الوقق المسجل أعلى فتحة باب

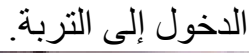

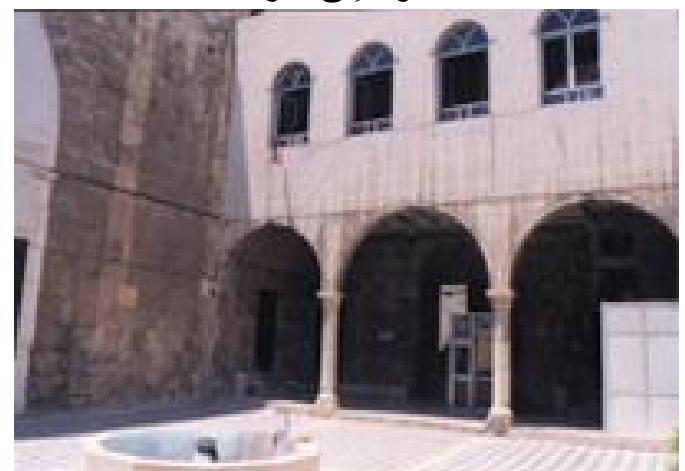

(لوحة 1) التربة و المدرستان الظاهرية: الضلع الغربى للصحن والى اليسار قسم

$$
\text { من الضلع الجنوبى. }
$$


دراسات في آثار الوطن العربي ؛

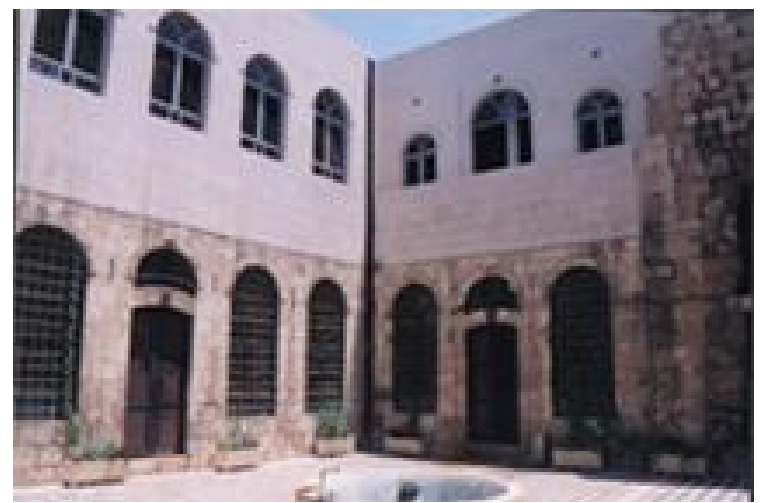

(لوحة r ا ) التربة و المدرستان الظاهرية: الز اوية الثمالية الثرقية من الصحن حيث يظهر قسم من الضلع

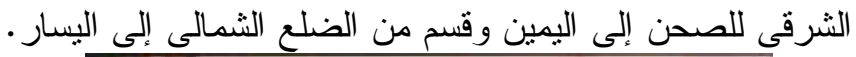

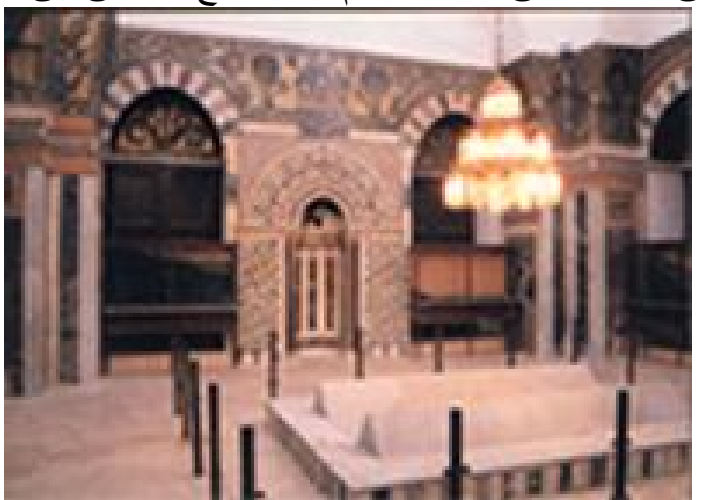

(لوحة r ا) التزبة و المدرستان الظاهرية:الجدار الجنوبى للتربة

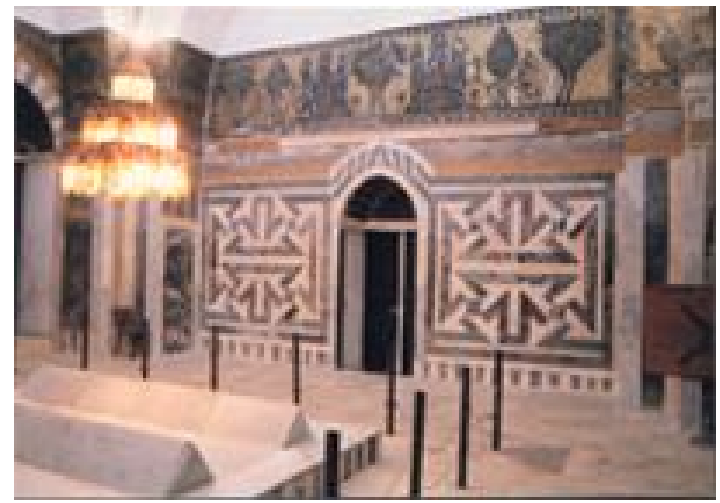

(لوحة ع ( ) التربة و المدرستان الظاهرية:الجدار الثمالى للتربة. 


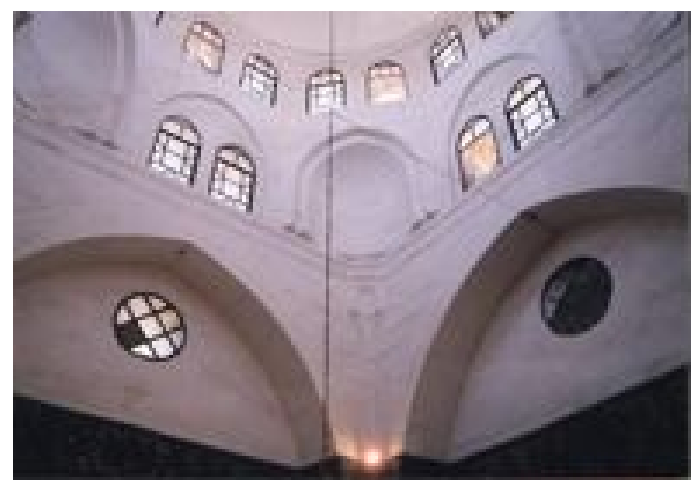

(لوحة 0 ( ) التربة و المدرستان الظاهرية: منطقة الانتقال وأواسطها ورقبة القبة.

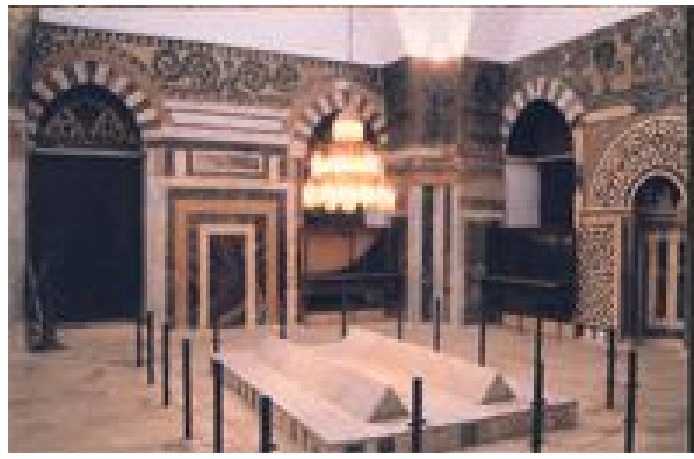

(لوحة 7 ( ) التربة و المدرستان الظاهرية: الضريح (التركيبة) الحديث ويظهر فى الإئ

خلفية الصورة الجدار الثرقى للتربة و الى اليمين قسم من الجدار الجنوبة الجنى لها.

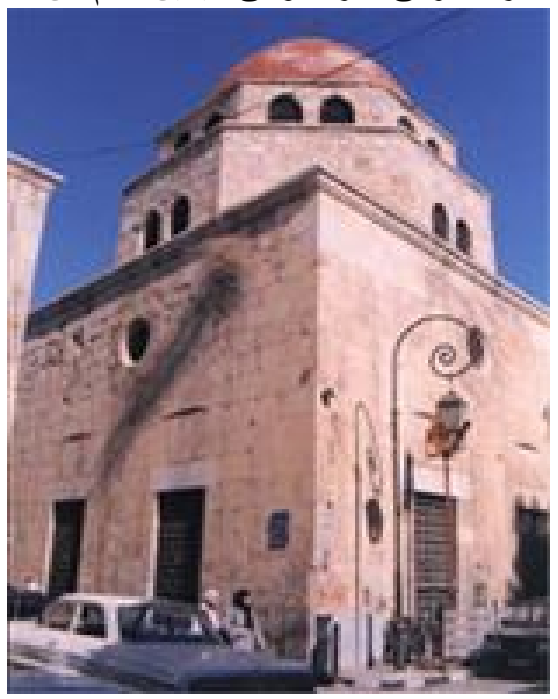

(لوحة V V التربة و المدرستان الظاهرية: و اجهتى التربة الغربية الرئيسية إلى اليسار و الجنوبية إلى اليمين. 
دراسات في آثار الوطن العربي ؛

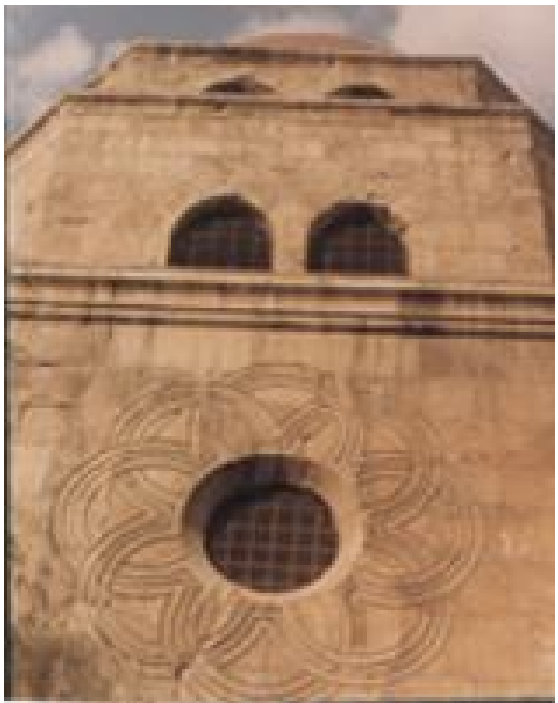

(لوحة ^1 ( ) التربة و المدرستان الظاهرية:زخرفة العقود المتقاطعة بالو اجهات الخارجية للتزبة حول القمريات المستديرة.

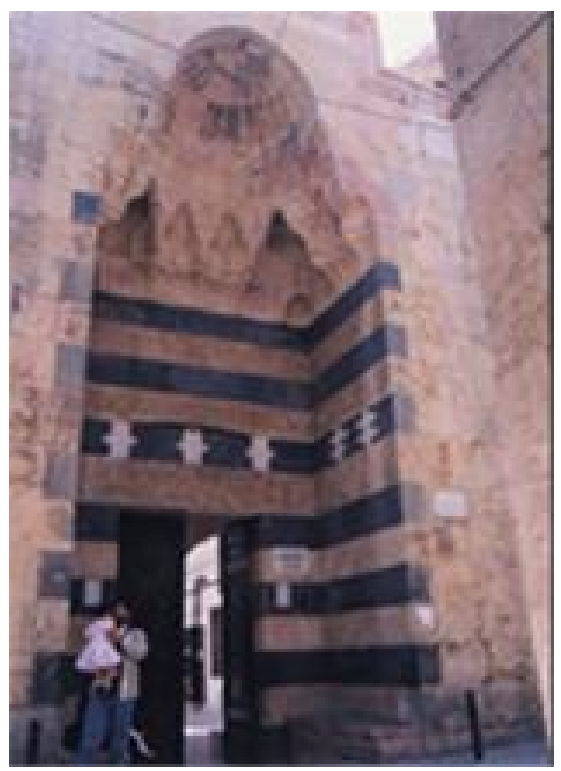

(لوحة 9 (1) التربة و المدرستان الظاهرية:المدخل الرئيسى بالواجهة الغربية. 
دراسات في آثار الوطن العربي ؛
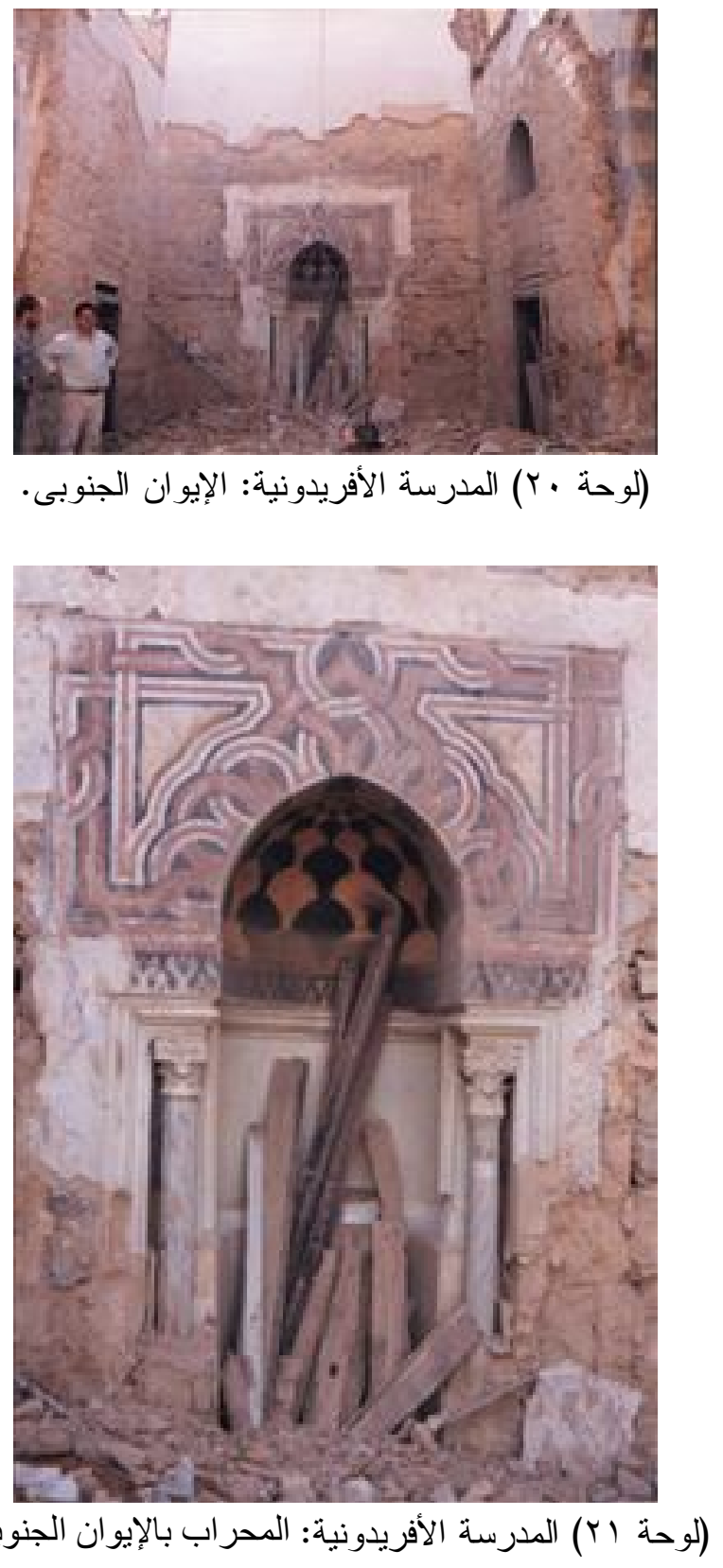

$1 \cdot 19$ 
دراسات في آثار الوطن العربي ؛

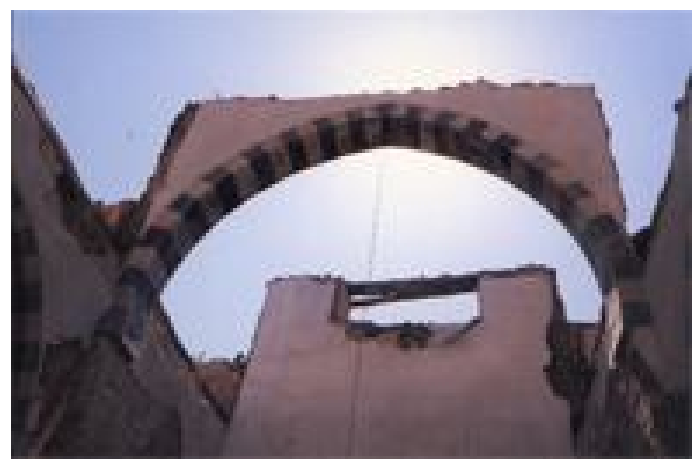

(لوحة r المدرسة الأفريدونية: سقف الإيوان الجنوبى (كثف سماوى) والقتحة

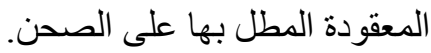
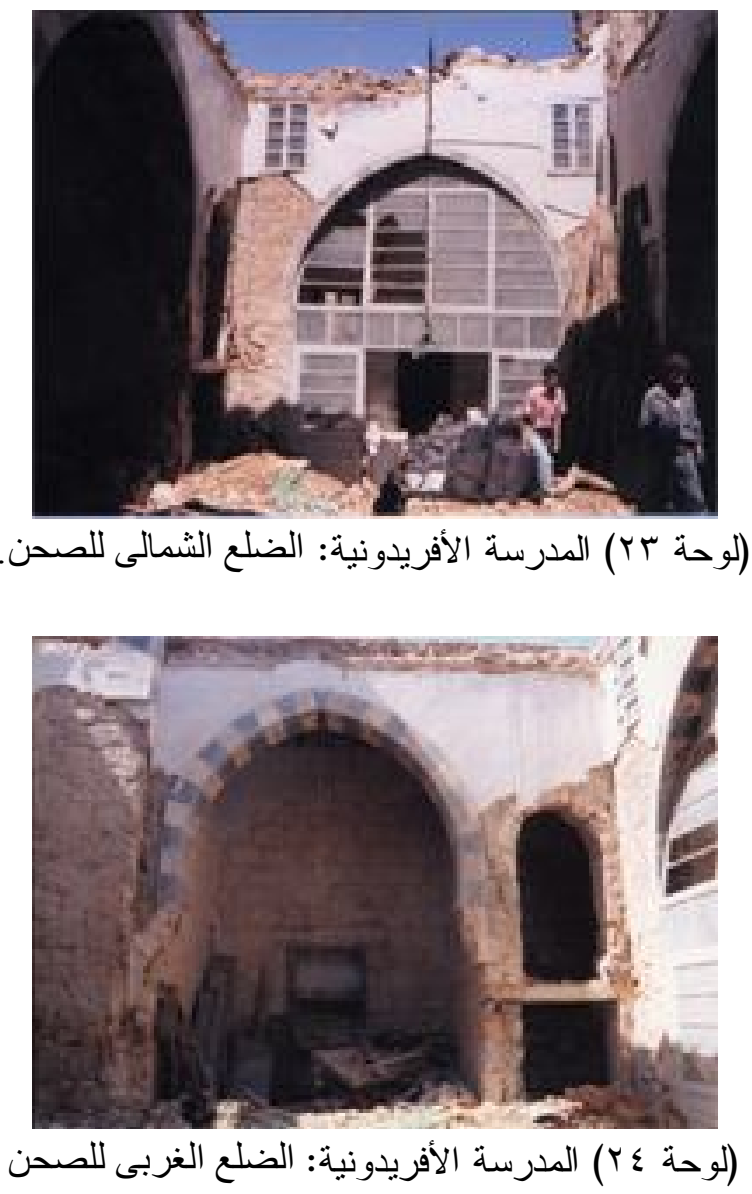

1.9. 
دراسات في آثار الوطن العربي ؛

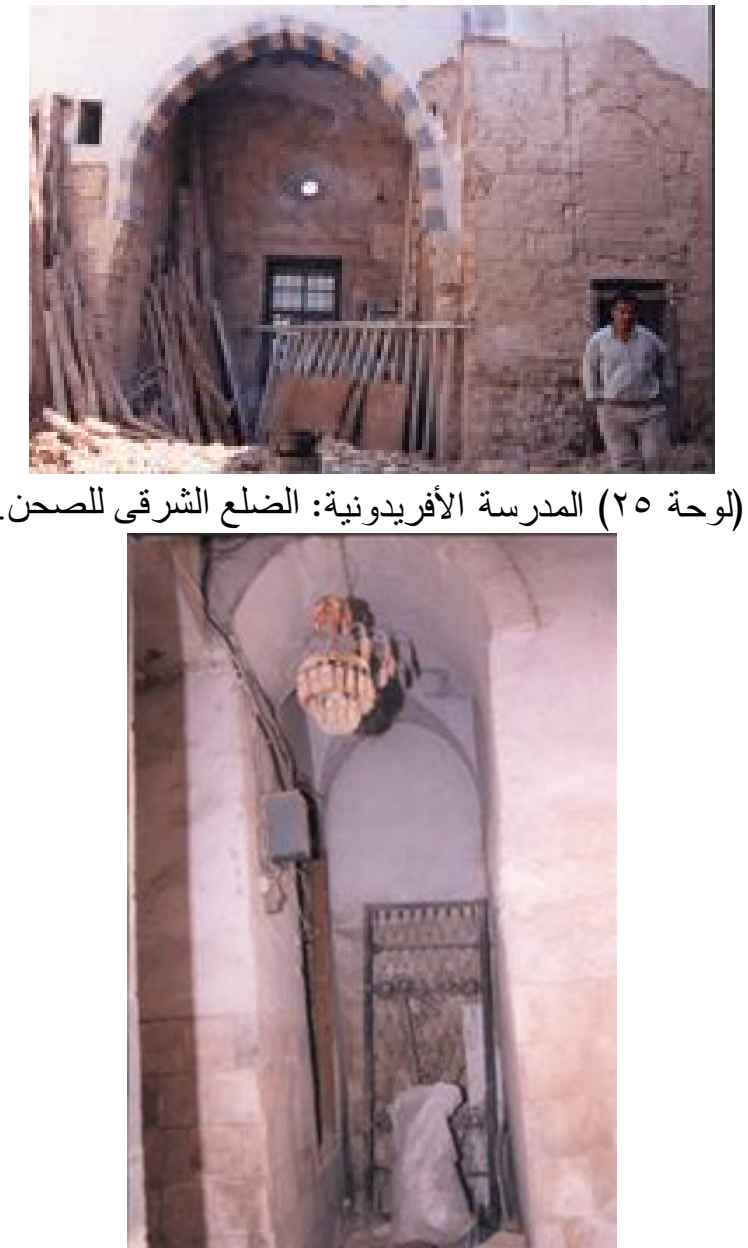

(لوحة بr) الددرسة الأفريدونية: الدهليز الواقع إلى يسار الداخل من الدذخل الرئيسى.

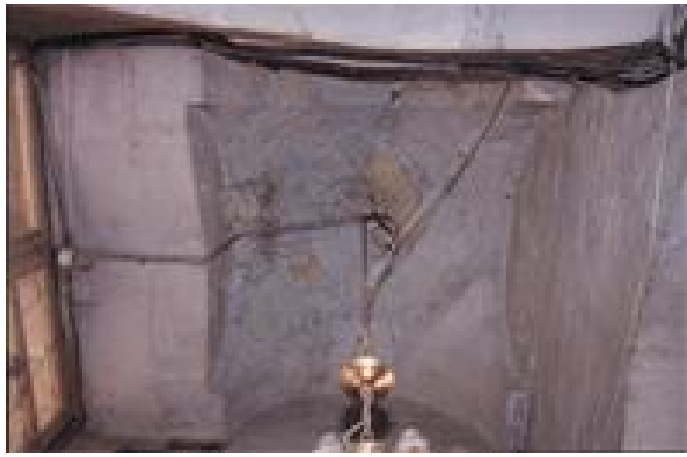

(لوحة YV) المدرسة الأفريدونية: سقف دركاة الدذخل الرئيسى. 
دراسات في آثار الوطن العربي ؛

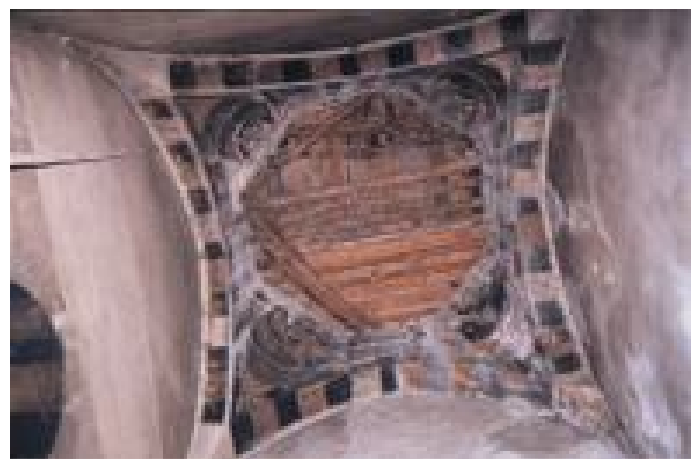

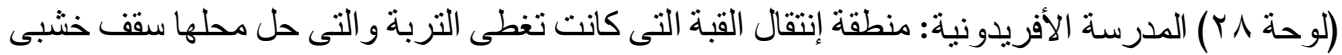
مسطح.
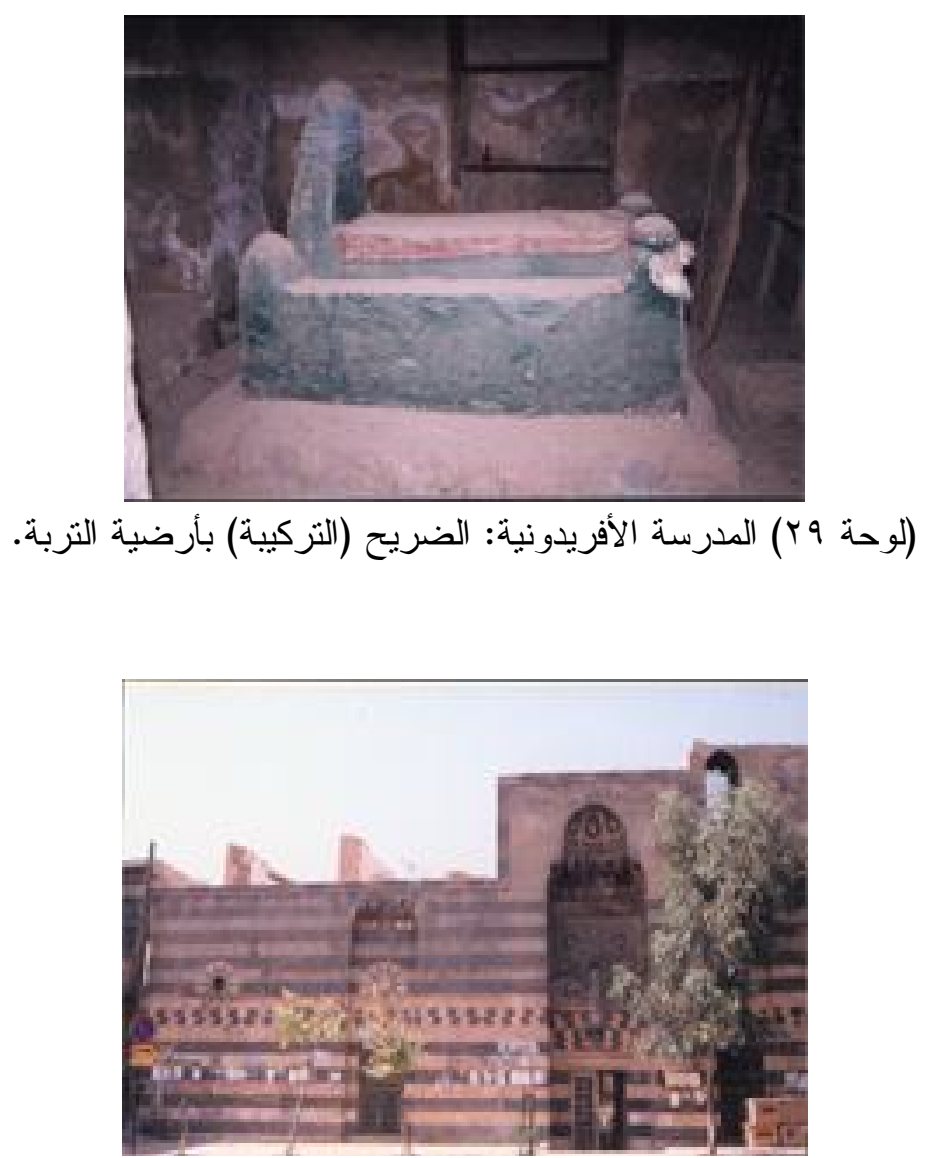

(لوحة • ( الددرسة الأفريدونية: الواجهة الثرقية الرئيسية. 
دراسات في آثار الوطن العربي ؛

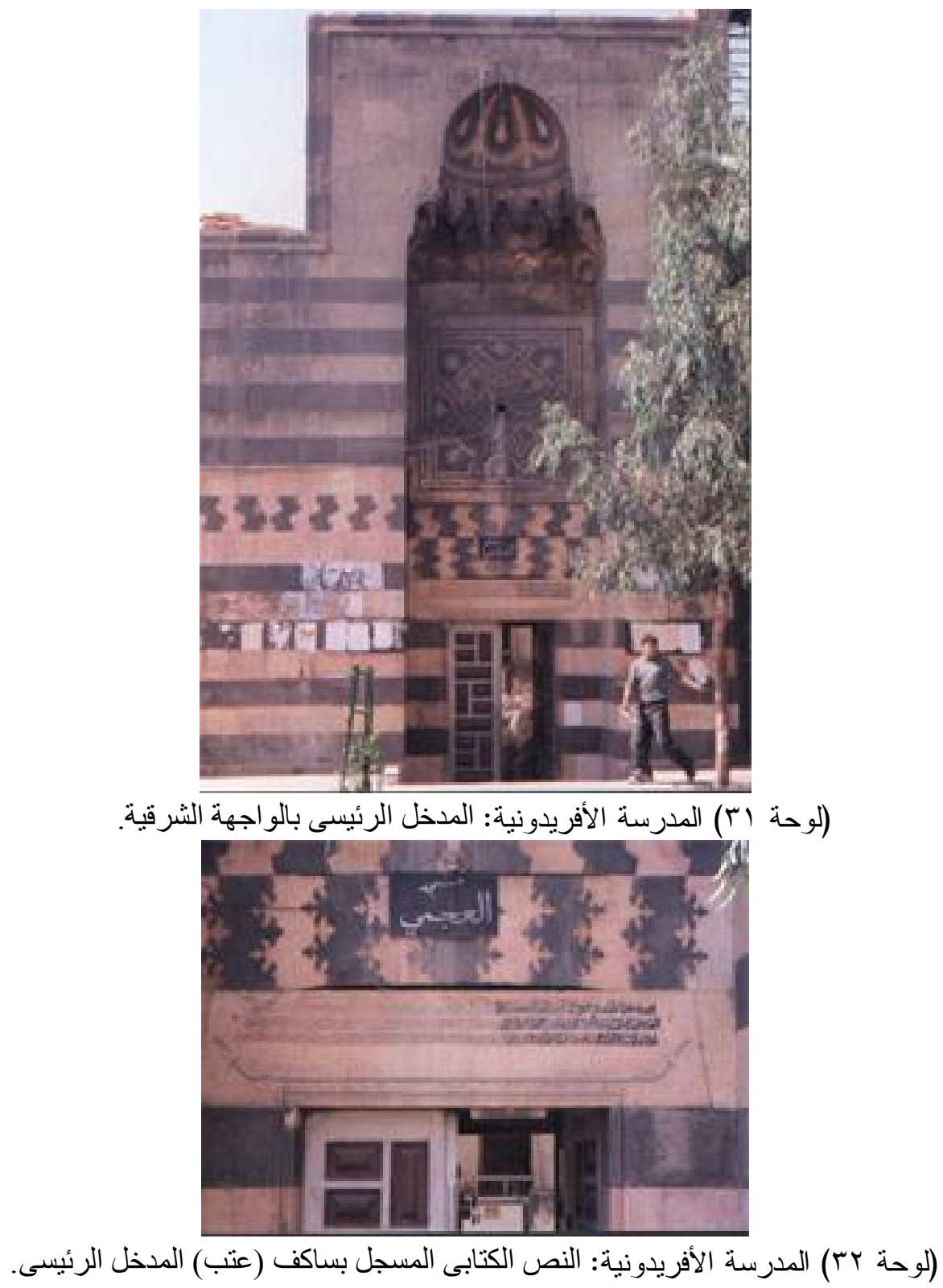


دراسات في آثار الوطن العربي ؛

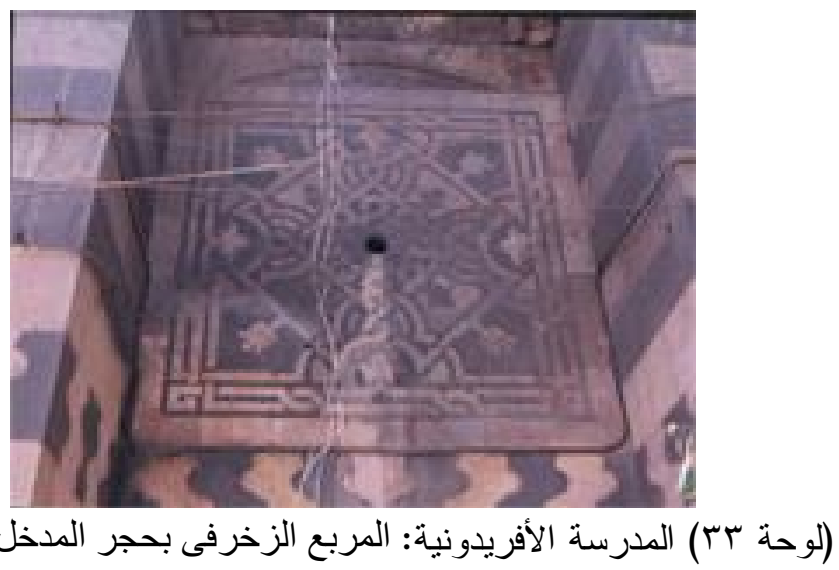

(لوحة r؟) الددرسة الأفريدونية: المربع الزخرفى بحجر الدذخل الرئيسى. 